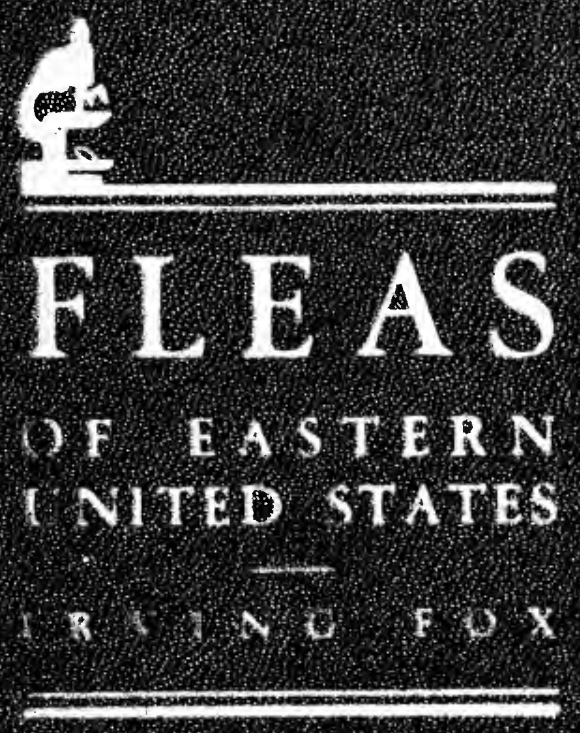




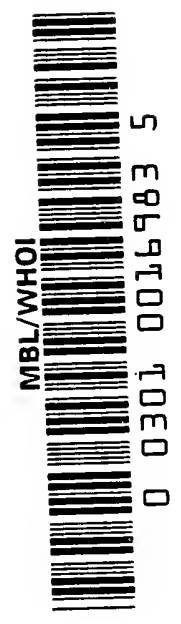


Fleas of Eastern United States 



\title{
FLEAS OF EASTERN UNITED STATES
}

\author{
BY \\ IRVING FOX
}

DEPARTMENT OF ZOÖLOGY AND ENTOMOLOGY, IOWA STATE COLLEGE

AMES, IOWA

THE IOWA STATE COLLEGE PRESS

FEBRUARY, 1940 
COPYRIGHT, 1940

BY THE COLLEGIATE PRESS, INCORPORATED

PRINTED AT THE COLLEGIATE PRESS, INCORPORATED IOWA STATE COLLEGE, AMES, IOWA, U. S. A. 


\section{PREFACE}

Fleas of the United States did not receive the special attention of any entomologist prior to 1895, when Baker's Preliminary Studies appeared. In 1904, this somewhat sketchy paper was followed by the same author's monumental revision of American Siphonaptera, and since then various other authors have contributed many short papers to the knowledge of this interesting group. Yet, in spite of these contributions and the growth of large collections of American fleas in the United States and abroad, no revision of the order as it occurs in this country has been attempted since Baker's great work. Even the faunal lists which play such a prominent part in the literature of other groups are unavailable for nearly all states. This lack of published information is particularly unfortunate in view of the tremendous medical importance of fleas, especially with regard to the increasing concern about their implication in the transmission of diseases other than the bubonic plague.

Since many of the types of western species are in collections unavailable to the author, this work was necessarily confined to a consideration of the species reported as occurring in the East. Therefore, the keys and diagnoses of larger groups apply to the fleas which inhabit the eastern half of the United States, i.e., the region east of the one-hundredth meridian with the exclusion of Texas. Fifty-five species, falling into five families comprising thirty-three genera, are now known to occur in this area. They parasitize about seventy-five mammalian and avian hosts including man and domestic animals, according to our present knowledge.

With but few exceptions, the writer has seen specimens of all the eastern fleas, but of the types, for the most part, only those in the United States National Museum have been available to him. All illustrations and descriptions are original except a few which, because of the inability to obtain material, have been adapted from previous publications.

The material which provided the basis for this work is in various institutions and private collections, but most of it is in the United States National Museum to the authorities of which and to Dr. H. E. Ewing, of the Bureau of Entomology and Plant 
Quarantine, the writer expresses his sincere appreciation not only for their kindness in lending material and offering records, but also in making desk space available for long periods. Thanks for permission to examine collections and use records are also due Dr. Karl Jordan, of the Tring Museum; Dr. R. L. Roudabush, of Ward's Natural Science Establishment; Dr. E. R. Becker and Mr. Thomas G. Scott, of Iowa State College; Dr. M. A. Stewart, of the University of California; Dr. H. H. Ross, of the Illinois Natural History Survey, and Dr. H. E. Jaques, of Iowa Wesleyan College. For technical advice and continuous encouragement, the writer is deeply indebted to $\mathrm{Dr} . \mathrm{H}$. H. Knight. of Iowa State College, under whose direction the work was done. 


\section{CONTENTS}

INTRODUCTION . . . . . . . . . . . . . . . . . . . . . . .

Order Siphonaptera Latreille . . . . . . . . . . . . 7

Suborder Integricipita OUdemans . . . . . . . . . . 7

Suborder Fracticipita Oudemans . . . . . . . . . . . $\quad 8$

Family Hectopsyllidae Baker . . . . . . . . . . 9

Family Pulicidae Stephens . . . . . . . . . . . 13

Family Dolichopsyllidae Baker . . . . . . . . . . 29

Family HyStrichopsyllidae TrRaboschy . . . . . . 77

Family Ischnopsyllidde WahLgREN . . . . . . . . . 104

Synonymic IndeX . . . . . . . . . . . . . . . . 111

Host Index . . . . . . . . . . . . . . . . . 114

Selected Bibliography . . . . . . . . . . . . . . . 121

INDEX . . . . . . . . . . . . . . . . . . . 125

Plates . . . . . . . . . . . . . . . . . . . 129 



\section{INTRODUCTION}

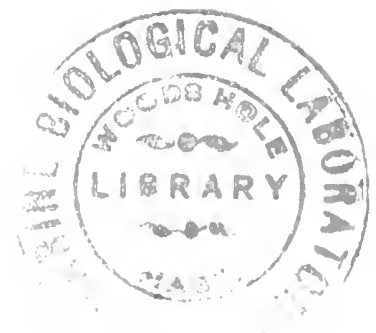

\section{COLLECTION AND PRESERVATION}

Fleas may be collected directly from the mammalian and avian hosts or their nests, runways, or burrows. In many instances certain species have been taken in sweepings and debris on the ground. Nests should be collected very soon after the young leave and each placed in a paper bag, or better under a bell jar where they can be watered occasionally to prevent drying out. If watered occasionally the immature stages continue to develop making it possible to obtain numerous specimens in all stages of development.

The hosts, themselves, should be captured by traps which take them alive, for fleas will soon leave the dead animal. After capture, the animal is anesthetized or killed by ether or chloroform and its ectoparasites dislodged by searching through the pelage with forceps or by combing with a fine-toothed comb. Taking the animal alive allows no opportunity for escape of the fleas, and thus best results are obtained. Under usual conditions, however, it is much more convenient to run traps which kill the animal. While a large percentage of the fleas are no doubt thus lost, a sufficiently large number remain to make this type of trapping worthwhile. Common mouse traps or guillotine traps may be used successfully to procure small animals such as wood mice and shrews. When abundant, rats and squirrels may be shot or even clubbed.

If possible, the dead animal should be placed immediately in a paper bag and carried to the laboratory where it can be examined under a binocular microscope. By this method not only fleas, but also lice, mites, and ticks can be collected. If an animal is heavily infested, it is helpful to stupefy its fleas with an insect powder, collecting them from white paper after combing the fur. Public health workers have found it easy to collect fleas from rats by placing the recently killed animal on a grating over water; the fleas in leaving the dead host jump into the water from which they may be collected readily.

Fleas are prepared for study by mounting in Canada balsam on glass slides. To accomplish this, various techniques have been used with good results. Soft parts and intestinal contents must be cleared before the important genitalia can be studied. 
Hence, it is customary to use $10 \%$ potassium hydroxide in water to dissolve the unsclerotized structures. It is best not to boil the $\mathrm{KOH}$, but to use it cold and allow action to go on for a day or two. Care should be taken not to allow the caustic to act too long, for it will distort, or even dissolve away entirely, important taxonomic structures. After its removal from $\mathrm{KOH}$, the material is washed in water and dehydrated by use of several degrees of alcohol. If the material is to be cleared in xylol or oil of cloves, it is best to run it through two changes of absolute alcohol. The absolute alcohol may be eliminated, however, if beechwood creosote is used as a clearing agent.

The writer makes use of the following technique which reduces the entire procedure to six steps:

1. Drop living flea (or one which has been killed in alcohol) in $\mathrm{KOH} \mathrm{10 \%} \mathrm{in} \mathrm{water.} \mathrm{Allow} \mathrm{to} \mathrm{remain} \mathrm{for} \mathrm{a} \mathrm{day}$ or two.

2. Transfer to water to which a few drops of $\mathrm{HCl}$ have been added. Allow to remain for one-half hour.

3. Dehydrate by running through 50\%; alcohol and

4. $95 \%$ alcohol for one-half hour each.

5. Clear in beechwood creosote for one hour.

6. Mount in Canada balsam.

It is essential to label adequately. Two labels are generally used for each glass slide. One, placed to the left, bears the name of the flea and by whom it was determined; the other, placed to the right, bears the name of the host, the locality, the date, and the collector's name.

\section{MORPHOLOGY AND TERMINOLOGY}

The body of the flea, like that of all insects, is divided into head, thorax, and abdomen, and each of these regions is of importance in taxonomy. In the suborder Fracticipita the head is subdivided by a dorsal sulcus extending from the place of insertion of the antenna on one side across the dorsum to the place of insertion of the antenna on the other side. The fleas of the suborder Integricipita, however, have no such sulcus, although there may be a highly sclerotized thickening extending from the top of the antennal groove to the dorsum of the head. Antennae, one on each side, are situated in antennal grooves which set off on the head a preantennal region and a postantennal region, each of which may be armed with bristles the arrangement of which is of great aid in classification. The upper 
portion of the preantennal region is called the frons, while the lower portion is known as the gena, but there is no distinct line of demarcation between the two areas.

In many genera the frons is notched or tuberculated, the anterior margin of the head bearing a notch or tubercle called the frontal notch or frontal tubercle. Frequently the gena is prolonged below and posterior to the eye into a heavily pigmented, highly sclerotized genal process, which may in some cases be difficult to distinguish from a spine of the genal ctenidium. Simple eyes, one on each side, are located near the third antennal segment; they vary in size and in prominence, being heavily pigmented and conspicuous in some groups, while vestigial or absent in others. When the preantennal region is armed with two rows of bristles, the lower row is called the ocular (genal) row, and its first bristle is termed the ocular bristle; the upper row is frequently designated as the frontal row. A conspicuous structure of the head, when it is present, is the genal ctenidium which consists of heavily pigmented spines. With the exception of the labial palpi, the mouthparts are of little systematic value. Each labial palpus (there are two) is variable in length and in the number of its segments; but the value of this variation is not the same in all groups, being of only specific importance in some cases while generic in others.

The thorax is of systematic importance because of the chaetotaxy of its sclerites which are formed as follows. Each segment (pro-, meso-, and metathorax) is divided into a dorsal notum or tergite and a ventral sternite. A vertical, rodlike sclerotization divides the meso- and metasternite into an anterior sternal portion and a posterior epimeron. The sternal portion is further divided into a lower part, the sternite, and an upper part, the episternum. The epimeron of the metathorax is broad and overlaps the abdomen supplanting the first abdominal sternite. The legs, with the exception of the tarsi, are of only occasional taxonomic importance. Each tarsus is armed on its fifth segment with plantar bristles whose position, whether lateral or ventral, and number are significant in generic delineation. A conspicuous feature of the thorax is the pronotal ctenidium, present in most groups but absent in some, which usually consists of long slender spines variable in number according to the group.

The abdomen is of importance to taxonomists largely because of the number of rows of bristles on each segment, the antepygidial bristles, and the genitalia. Each segment consists of 
a dorsal tergite and a ventral sternite. The seventh tergite usually bears one or more stout bristles on each side, the antepygidial bristles, which are of great systematic importance because of their variablity in the different groups.

The genitalia of both sexes are of tremendous taxonomic importance. In the male they have evolved in part from the ninth abdominal segment, the tergite forming the clasper. Each clasper (there is one on each side) consists of a broad plate which ventrally is prolonged to form a manubrium and dorsally bears a conelike protuberance known as the process of the clasper. Articulated to the clasper on each side of the body is a movable process called the movable finger (exopodite, according to some authors) whose shape and size are very significant. Sometimes both processes are movable, but in most instances the arrangement is as described, with only one process capable of movement. The ninth sternite, which forms the lower clasper, has the shape of a boomerang since it consists of an anterior or vertical arm and a posterior or horizontal arm (also called the ventral arm). The penis is long and bladelike and bears posteriorly a paramere which in certain groups is very significant in classification. Below the penis is the spring which may be long or short and, if long, is frequently coiled distally. In the female the shape of the seventh sternite is of great importance, particularly if its posterior margins are sinuate or entire. The form of the heavily sclerotized receptaculum seminis, consisting of a head and tail, is also of great significance.

For illustrations of the structural terms discussed above, see Plate I.

\section{LIFE HISTORY AND CONTROL}

Fleas undergo complete metamorphosis involving four distinct stages-egg, larval, pupal, and adult. The eggs, larvae, and pupae are residents of the nest of the host and not parasitic, according to most authors; the adults, however, feed exclusively on blood. The eggs are laid by the adult female either in the nest of the host or among its hairs or feathers without any agglutinating material to keep them attached; hence, they are easily shaken off into places where the host sleeps or rests.

The rate of development of the cream-colored, oval eggs varies among the different species and also depends in a large measure on temperature and humidity. When the eggs hatch they give rise to white or yellowish larvae which are cylindrical in shape and very slender. The larvae are very active, 
squirming about and feeding upon the organic debris in which they live, particularly the excreta of the adults. In structure they are more or less maggot-like, legless and eyeless. The body as a whole is divided into a head, three thoracic segments, and ten abdominal segments which are richly provided with bristles. When ready to pupate (after two moults according to many authors) the mature larva spins a silken cocoon covered with dust and attached to the substratum. Within this cocoon the pupa develops, and in the later stages of its development the species can frequently be identified. The length of life of the mature flea varies with the species and with conditions. Certain species are exceedingly hardy and are capable of going without food for unbelievably long periods. Bishopp (1931) states that during the summer the average longevity of the human flea without food is about two months, of the dog flea somewhat less, and the sticktight flea still less.

The fleas which have proven themselves pests in the East are the human flea, the dog and cat fleas, the two chicken fleas, and the oriental rat flea. When these are in human habitations, they usually originate from the sleeping places of animals. If they are in hog pens, barns, cellars, outhouses or beneath buildings the most effective control is spraying with creosote oil, according to Bishopp (1937), and usually one light spraying will wipe out an infestation. Since creosote oil is objectionable because of its odor and causticity, it is desirable to use some other material for controlling fleas in living quarters. The scattering of flaked naphthalene over the floor of each infested room at the rate of five pounds per room has been recommended.

Dogs and cats may be kept free of fleas by regularly applying derris or pyrethrum powder next to the skin. Hogs may be kept free of the human flea by sprinkling their backs with crankcase oil or crude petroleum every two or three weeks. For controlling the sticktight flea on chickens, dogs. and cats, it is necessary to bring derris powder or carbolated vaseline into actual contact with the fleas. Rat fleas and ground squirrel fleas can be controlled only by campaigning against their hosts. This may take the form of complete elimination of the animals by fumigation, poisoning, trapping, or shooting. or by rat-proofing buildings where rats can obtain food and shelter. 



\section{ORDER SIPHONAPTERA LATREILLE}

Siphonaptera Latreille, 1825, Fam. Nat. du Regne Animal, p. 334.

Suctoria Retzius, 1783, Caroli De Geer Genera et Species Insectorum, p. VI.

Aphaniptera Kirby and Spence, 1826, Introduction to Entomology. 4:382.

Wingless; the body laterally compressed. Mouthparts formed for piercing and sucking. Antenna three-jointed and situated in a groove. Eyes simple, sometimes vestigial or absent. Tarsi five-jointed; the coxae well-developed. Metamorphosis complete.

Key to the Suborders of Siphonaptera

Preantennal and postantennal regions of the head not separated by a dorsal sulcus, although there may be a heavy sclerotization above the antenna $\ldots \ldots \ldots \ldots \ldots \ldots \ldots \ldots \ldots . \ldots \ldots$ Suborder Integricipita

Preantennal and postantennal regions of the head separated above by a sulcus extending from the antennal groove to the dorsum and permitting motion between the two regions ............. Suborder Fracticipita

\section{SUBORDER INTEGRICIPITA OUDEMANS}

Integricipita Oudemans, 1908, Tijd. v. Ent., 51:92.

This suborder is represented in the East by three families.

Key to the Families of Integricipita

1. The three thoracic tergites together shorter than the first abdominal

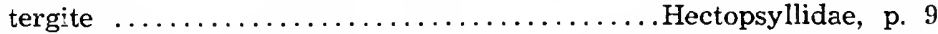

The three thoracic tergites together not shorter than the first abdominal

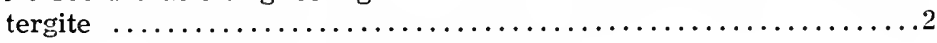

2. One row of bristles to each abdominal tergite ........ Pulicidae, p. 13 Two or more rows of bristles to each abdominal tergite 


\section{SUBORDER FRACTICIPITA OUDEMANS}

Fracticipita Oudemans, 1908, Tijd. v. Ent., 51:92.

This suborder is represented in the East by but two families.

Key to the Families of Fracticipita

Head with two separated genal spines only in the genus Peromyscopsylla; the spines not modified into broad plates (not on bats) ............

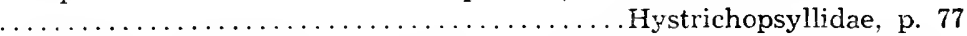

Head with two separated genal spines modified to form broad plates (on bats) $\ldots \ldots \ldots \ldots \ldots \ldots \ldots \ldots \ldots \ldots \ldots \ldots \ldots \ldots \ldots \ldots \ldots \ldots \ldots$ Ischnopsyllidae. p. 104 


\section{FAMILY HECTOPSYLLIDAE BAKER}

1904 Hectopsyllidae Baker, Proc. United States Nat. Mus., 27:375.

1904 Sarcopsyllidae Baker, Proc. United States Nat. Mus., 27:373.

1905 Hectopsyllidae Baker, Proc. United States Nat. Mus., 29: 123.

1905 Rhynchoprionidae Baker, Proc. United States Nat. Mus., 29:123.

1906 Hectopsyllidae Oudemans, Nov. Zool., 16:157.

1925 Tungidae C. Fox, Insects and Disease of Man, p. 130.

1926 Sarcopsyllidae Dampf, Ent. Mitc., 15:378.

1929 Hectopsyllidae Ewing, Manual External Parasites, p. 178.

1936 Hectopsyllidae Wagner, Tierwelt Mitteleuropas, Bd. VI, Abt. XVII, s. 4.

The members of this family are distinguished by the great reduction of the thoracic segments which together are usually not longer than either the head or the first abdominal tergite. The legs are rather weak, and the abdomen in the female is prominently distended. No antepygidial bristles are present.

But one genus belonging to this family has been reported from the East. It may be characterized as follows.

\section{ECHIDNOPHAGA OLLIFF}

Echidnophaga Olliff, 1886, Proc. Linn. Soc. N. S. Wales, 1:172.

\section{Genotype: Echidnophaga ambulans Olliff}

Neither a genal nor a pronotal ctenidium present. Head angulate in front. Frontal tubercle absent. Abdominal segments II to VIII each with a conspicuous spiracle. Hind coxa produced at the apex into a broad tooth; hind coxa also armed with a patch of spinelets on the inner side (Plate II, fig. 5). Fifth tarsal segment of each leg armed with three pairs of stout lateral plantar bristles anterior to which there may be one or two pairs of much more slender bristles.

This genus is represented in the East by but one species which is a widespread pest of chickens in the South. Its depredations are so great as to cause serious losses to the poultry business. 
Echidnophaga gallinacea (Westwood)

(Plate II)

1875 Sarcopsyllus yallinaceus Westwood, Ent. Mo. Mag., 11: 246.

1890 Pulex pallulorum Johnson, Proc. Ent. Soc. Washington, 1:59.

1855 Sarcopsylla gallinacea Baker, Can. Ent., 27:21.

1896 Sarcopsylla gallinacea Osborn, United States Dept. Agric. Div. Ent., Bull. 5 (n.s.), p. 144, figs. 76, 77.

1904 Xestopsylla gallinacea Baker, Proc. United States Nat. Mus., 27:375.

1905 Argopsylla gallinacea Baker, Proc. United States Nat. Mus., 29:138.

1906 Echidnophaga gallinacea Jordan and Rothschild, Liverpool Univ., Thompson Yates and Johnson Lab. Rep. 7 (n.s.), p. 52.

1907 Xestopsylla gallinacea Herrick, Jour. Econ. Ent., 1:355.

1910 Echidnophaga gallinacea Banks, United States Public Health Mar. Hosp. Ser., Bull. 30:77.

1914 Echidnophaga gallinacea C. Fox, United States Public Health Hyg. Lab., Bull. 97, Pl. XVI, fig. 29; Pl. XXII, fig. 72.

1915 Echidrophage gallinacea Illingworth, Jour. Econ. Ent., 8: 492.

1925 Echidruphaga gallinacca C. Fox, Insects and Disease of Man, p. 131, fig. 59.

1926 Echidnophaga gallinacea Parman, Jour. Econ. Ent., 19:644.

1928 Echidnophaga gallinacea Stewart, Cornell Univ. Agric. Exp. Sta., Mem. 101, p. 868.

1929 Echidnophaga gallinacea Ewing, Manual External Parasites, p. 179, fig. 94.

1929 Echidnophaga gallinacea Hasseltine, United States Public Health Ser., Rep. 44: 583.

1929 Echidnophaga gallinacea Jordan, Nov. Zool., 35: 176.

1931 Echidnophaga gallinacea C. Fox, United States Public Health Ser., Rep. 46:574.

1932 Echidnophaga gallinacea Stewart, Jour. Econ. Ent., 25:164.

1933 Echidnophaga gallinacea Stewart, Jour. New York Ent. Soc., 41:253.

1934 Echidnophaga gallinacea Shaftesbury, Jour. Elisha Mitchell Sci. Soc., 49: 248 .

1935 Echidnophaga gallinacea Vogel and Cadwallader, United States Public Health Ser., Rep. 50:1953.

1937 Echidnopliaga gallinacea Jordan, Nov. Zool., 40:283.

MaLe. Preantennal region of the head with but two bristles which comprise the frontal row. Eye heavily pigmented, oval in shape. Maxilla short and broad, triangular in shape. Mandibles wide and prominent, deeply serrated (Plate II, fig. 4). Second segment of the antenna with three or four long bristles, some of which are about as long as the third antennal segment. Pronotum and mesonotum each with a single row of long bristles. Each abdominal tergite armed with at least one long bristle in the dorsal region. Modified SEgments: Clasper with two processes, one long with a number of bristles along the anterior margin, the other much smaller and narrower. Mov- 
able finger rounded apically and curved toward the smaller process. Distally, the movable finger bears several bristles of which one is longer than the others. Manubrium long and slender. Penis long and broad, terminating in a curved point; spring not much longer than the penis and not completing a single turn. For further details concerning the structure of the male genitalia, see Plate II, fig. 3 .

Female. General structure and chaetotaxy essentially as in the male. Receptaculum seminis somewhat in the form of a question mark; much broader ventrally than dorsally. For further details concerning the structure of the female genitalia. see Plate II, figs. 1 and 2.

Records. ALABAMA-Auburn, June, on "dogs," numerous specimens. ARKANSAS-Imboden, November 27, 1931, on same host, four females (B. C. Marshall). FLORIDA-Leon Co., April 13-15, 1926, on "quail," two females (H. L. Stoddard) ; Tallahassee, June 15, 1937, on "Rattus alexandrinus," female; July 12, 1937, on same host, male, three females; January 21, 1937, on same host, three females. GEORGIA-Newton, July 26, 1937, on "wharf rat," numerous specimens; April 1. 1937, on "Vulpes fulva," two females (B. V. Travis); July, 1936, on Urocyon cinereargenteus floridanus Rhoads, female, two males (E. V. Komarek); July 8, 1936, on "Mephitis elongata," male, three females (Travis and Komarek); Beachton, December 31, 1927, on "Cooper's Hawk," two females (W. B. Bell) ; Camden Co., April 25, 1933, on "Urocyon cinereoargenteus," male (F. Harper); Nashville, December 5, 1935, on "rabbit," male, three females; May 12, 1936, on "gray squirrel," four females; Valdosta, October 22. 1935, on "rabbit," female; November 22, 1935, on same host, four females; November 29, 1935, on "roof rat," female (H. Hixson). NORTH CAROLINA -Wilmington, June 15, 1908, on "dog," five specimens (W. F. Merritt). SOUTH CAROLINA-Orangeburg, November, 1894. on "horses," numerous specimens (J. C. Hartzell, Jr.); Florence, June 16, 1935, on "jaybird," female (C. F. Rainwater). VIRGINIA-Virginia Beach, July 19, 1928, on "rat," two females (H. E. Ewing and C. East); Ocean View, May 29, 1938. on "cat," numerous specimens (P. W. Oman): Cape Henry, September 8, 1927, on "chicken," two females (J. Mullenfeld).

EAstern Hosts. "Horse," "Dog," "Cat," "Rat," "Wharf-rat," Roof-rat ("Rattus alexandrinus"), Gray Fox ("Urocyon cinereoargenteus"), Red Fox ("Vulpes fulva"), Skunk ("Mophitis elongata," "Spilogale ambarvalis," etc.), "Gray Squirrel," 
"Rabbit," "Coyote," Cooper's Hawk (Accipter cooperi (Bonaparte)), Domestic Turkey ("Melagris gallopava"), "Deer," English Sparrow (Passer domesticus domesticus (Linnaeus)), Florida Bob-white (Colinus virginianus floridanus (Coues)), "Jaybird," "Quail," "Chicken."

EAstern localities. Alabama, Arkansas, Florida, Georgia, Kansas, Louisiana, Minnesota, Mississippi, Missouri, New York, North Carolina, Oklahoma, Pennsylvania, South Carolina, Texas, Virginia. (Tropical regions of the world.)

Type material. Numerous specimens from the "domestic fowl" at Colombo, Ceylon. Location of the types not ascertained.

\section{Tunga penetrans (Linnaeus)}

(Plate III, figs. 8, 9)

1758 Pulex penetrans Linnaeus, Syst. Nat. 10th Ed., p. 614.

1838 Tunga penetrans Jarocki, Zoology or Gen. Desc. Anim., p. 50, Pl. II, figs. 10-13.

1921 Tunga penetrans Rothschild, Ectoparasites, 1:129.

This species, which is commonly known under the various popular names (particularly "jigger" and "chigoe"), is an important pest in tropical and subtropical America but is not yet established in the United States. Some years ago Baker (1904. p. 374) suggested that it might be introduced into Florida, but no authentic record of such an occurrence has yet been made known. It may readily be separated from $E$. gallinacea by the absence of a patch of spinelets on the inner side of the hind coxa, and by the character of the head and genitalia (Plate III. figs. 8,9$)$. 


\section{FAMILY PULICIDAE STEPHENS}

1829 Pulicidae Stephens, Syst. Cat. British Insect, pt. II, p. 328.

1895 Pulicidae Baker, Can. Ent., 27:20.

1904 Pulicidae Baker, Proc. United States Nat. Mus., 27:377.

1905 Pulicidae Baker, Proc. United States Nat. Mus., 29:127.

1909 Pulicidae Oudemans, Nov. Zool., 16:157.

1915 Pulicidae Rothschild, Ent. Mo. Mág., 51:89.

1926 Pulicidae Dampf, Ent. Mitt., 15:379.

1929 Pulicidae Ewing, Manual External Parasites, p. 160.

1936 Pulicidae Wagner, Tierwelt Mitteleuropas, Bd. 6, Abt. 17, s. 20.

The members of the family Pulicidae are characterized particularly by the possession of a single row of bristles on each abdominal tergite. These fleas are further distinguished by having large and well-developed eyes. The frontal notch is absent. The club of the antenna is segmented only on one side. A series or patch of small spinelike bristles is present on the inner side of the hind coxa. Four pairs of lateral plantar bristles and a distal submedian pair are present on the fifth tarsal segment of each leg. One long antepygidial bristle is flanked on each side by a much smaller bristle present on a side.

The Pulicidae are represented in the East by five genera which include several species of tremendous medical importance.

\section{Key to the Eastern Genera of Pulicidae}

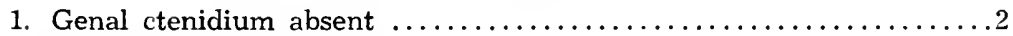

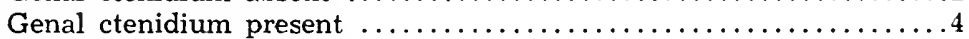

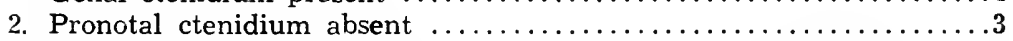

Prontal ctenidium present ................... Hoplopsyllus, p. 14

3. Mesosternite divided by a distinct vertical rodlike sclerotization ......

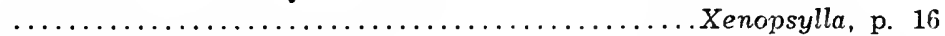

Mesosternite not so divided ....................... 18

4. Genal ctenidium more or less vertical with straight blunt spines ...... Cediopsylla, p. 21

Genal ctenidium more or less horizontal with curved spines tapering to sharp points $\ldots \ldots \ldots \ldots \ldots \ldots \ldots \ldots \ldots$. Ctenocephalides, p. 24 


\section{HOPLOPSYLLUS BAKER}

Hoplopsyllus Baker, 1905, Proc. United States Nat. Mus., 29:128.

\section{Genotype: Pulex anomalus Baker}

Eye bristle not placed higher than the eye itself. Genal ctenidium absent. Pronotal ctenidium present. Mesosternite divided by a distinct vertical rodlike sclerotization.

This genus is represented in the East by two closely related species which are parasitic chiefly on rabbits and hares. The females of these two species are separated by characters which do not lend themselves readily to arrangement in key form. The males may be differentiated by the following key:

\section{Key to the Eastern Species of Hoplopsyllus (males only)}

Posterior process of the movable finger not more than twice as long as the anterior process .................................. Posterior process of the movable finger more than twice as long as the

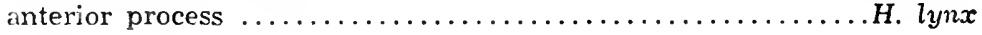

\section{Hoplopsyllus affinis (Baker)}

(Plate IV, figs. 12, 14, 15)

1904 Pulex affinis Baker, Proc. United States Nat. Mus., 27:382.

1905 Hoplopsyllus affinis Baker, Proc. United States Nat. Mus., 27:130.

MALE. Preantennal region of the head with only two bristles, one of which is located near the eye, the other at the base of the maxillary palpus. First segment of the antenna with a number of slender bristles along the posterior edge and apically. Second antennal segment with four or five long bristles. Postantennal region of the head with but two bristles in addition to the marginal row of four or five bristles. Near the third antennal segment is a group of about seven setae. Pronotal ctenidium consisting of eight or nine spines on a side. Pronotum, meso-, and metanotum each armed with a single row of bristles. Modified segments: Clasper with two processes, the anterior broad and lobular, armed with about eight stout bristles; the other much more slender with a broad black tooth apically, usually less than one and one-half times as long as the anterior process. Manubrium small and broad, curved upward. Penis long, slender, and bladelike; spring long, but not completing a turn in the specimens examined. For further details concerning the structure of the male genitalia, see Plate IV, fig. 14.

Female. Chaetotaxy of the head (Plate IV, fig. 12) and gen- 
eral structure essentially as in the male. Head of the receptaculum seminis rounded, much shorter than the tail. For further details concerning the structure of the female genitalia, see Plate IV, fig. 15.

REcoRds. IOWA-Ames, 1935, on "house-rat," female: May, 1934, on "cottontail," male; December 6, 1934, on "red fox," male and female (R. L. Roudabush); Hawarden, May, 1938, "in house," male and female. OKLAHOMA-no more specific locality, on "rabbit," male and female.

EASTERN HOSts. "House-rat," "Cottontail," "Red Fox," "Rabbit."

Eastern localities. Iowa, Oklahoma. (This species is known to occur in several western states. Iowa appears to be its eastern limit.)

Type Material. Male and female from near Grand Canyon, Arizona, on "Lepus species," in the United States National Museum.

Hoplopsyllus lynx (Baker)

(Plate IV, figs. 11, 13)

1904 Pulex lynx Baker, Proc. United States Nat. Mus., 27:383, PI. X, figs. 7-11, Pl. XI, figs. 1, 2.

1905 Hoplopsyllus lynx Baker, Proc. United States Nat. Mus., 29:130.

1929 Hoplopsyllus glacialis lynx Jordan, Nov. Zool., 35:175.

1937 Hoplopsyllus glacialis lynx Jordan, Nov. Zool., 40: 283.

Male. Chaetotaxy of the head and general structure essentially as in $\mathrm{H}$. affinis. The species differs particularly in the posterior process of the clasper which is much longer than in H. affinis. The anterior process bears about twelve long stout bristles. For further details, see Plate IV, fig. 13.

Female. Chaetotaxy and general structure essentially as in the male. Receptaculum seminis differing from that of $H$. affinis particularly in the shape of the head, which is more or less oval and longer than wide, rather than rounded and about as long as wide. For further details concerning the structure of the female genitalia, see Plate IV, fig. 11.

EASTERN Hosts. American Varying Hare ("Lepus americanus"), Canada Lynx ("Lynx canadensis").

Eastern localities. Maine and New Hampshire.

Type material. Male and two females from Moscow, Idaho, on "Lynx canadensis" in the United States National Museum. 


\section{XENOPSYLLA GLINKIEWICZ}

Xenopsylla Glinkiewicz, 1907, Sitzber. Ak. Wiss. Wien, 116: 385.

\section{Genotype: Pulex cheopis Rothschild}

No genal or pronotal ctenidium present. Ocular bristle situated above the eye. Mesosternite broad, divided by a vertical, rodlike sclerotization. Posterior margin of the head with several bristles.

This genus is represented in the East by a single species, the oriental rat flea, which is an important transmitter of several diseases.

\section{Xenopsylla cheopis (Rothschild) \\ (Plate V, figs. 16, 18, 20)}

1903 Pulex cheopis Rothschild, Ent. Mo. Mag. (2nd ser.), 14:85, Pl. I, figs. 3 , 9; Pl. II, figs. 12, 19.

1908 Loemopsylla cheopis Rothschild, Parasitology, 1: 42, P1. I; Pl. II, fig. 8; Pl. IV, fig. 8; Pl. VI, fig. 1.

1909 Xenopsylla cheopis Rothschild, Nov. Zool., 16:132.

1910 Loemopsylla cheopis C. Fox, United States Public Health and Mar. Hosp. Ser., Bull. 30, p. 138, Pl. III, figs. 1-4.

1914 Xenopsylla cheopis C. Fox, United States Public Health Hyg. Lab., Bull. 97, Pl. XIV, fig. 22; Pl. XXI, fig. 62.

1925 Xenopsylla cheopis Wallace, Dept. Conser. Indiana, Div. Ent. Rep., p. 14.

1925 Xenopsylla cheopis C. Fox, United States Public Health Se1., Rep. 40:1917.

1925 Xenopsylla cheopis C. Fox, Insects and Disease of Man, p. 133, figs. $61,62$.

1928 Xenopsylla cheopis Stewart, Cornell Univ. Agric. Exn. Sta., Mem. 101, p. 868.

1929 Xenopsylla cheopis Hasseltine, United States Public Health Ser., Rep. 44: 583.

1929 Xenopsylla cheopis Jordan, Nov. Zool., 35:176.

1929 Xenopsylla cheopis Ewing, Manual External Parasites, p. 163, fig. 90.

1933 Xenopsylla cheopis Stewart, Jour. New York Ent. Soc., 41:254.

1934 Xenopsylla cheopis Shaftesbury, Jour. Elisha Mitchell Sci. Soc., $49: 249$.

1934 Xenopsylla cheopis Roudabush and Becker, Science, 80:97.

1935 Xenopsylla cheopis Vogel and Cadwallader, United States Public Health Ser., Rep. 50:1953.

1936 Xenopsylla cheopis Riley, Journal-Lancet, 56:591.

1938 Xenopsylla cheopis Ewing and Fox, Science, 88: 427.

1939 Xenopsylla cheopis Roudabush, Science, 89: 79.

MALE. Preantennal region of the head with but two widely separated bristles, one of which is located above the eye, while 
the other is situated at the base of the maxilla. Several small setae situated between the two bristles. Labial palpus reaching almost to the apex of the fore coxa. First antennal segment with about ten bristles of various sizes; second antennal segment with about four long bristles. Posterior to the third antennal segment is a series of about twelve small setae. Bristles of the postantennal region arranged in three rows; first and second row reduced to one bristle each, the third row consisting of five long bristles which alternate with four small setae (Plate V, fig. 20). Each segment of the thorax armed with a single row of long bristles alternating with small setae. Modified SEGMENTS: Clasper with two processes; one narrow and curved outward, the other more or less in the form of a flap, its upper margin with a number of bristles. Penis bladelike ending in a sharp point; spring long but not completing a single turn in the specimens examined. Posterior arm of sternite IX expanded apically and armed with a number of bristles. For further details concerning the structure of the male genitalia, see Plate V, fig. 16.

FEMALE. Chaetotaxy of the head and general structure essentially as in the male. Receptaculum seminis large and conspicuous; basal portion of the tail almost as wide as the head. For further details of the structure of the female genitalia, see Plate V, fig. 18.

RECoRDS. DISTRICT OF COLUMBIA - Washington, September 17, 1902, on "Mus domestica," male (H. S. Barber); August 29, 1935, on "rats," male, three females (C. N. Smith). FLORIDA - Jacksonville, January 25, 1934, on Rattus norvegicus (Erxleben), numerous specimens; Tallahassee, June 15, 1937, on "Rattus alexandrinus," female, two males; January 16, 1937, on "Rattus rattus," male. GEORGIA-Thomasville, July 18, 1934, on Sigmodon hispidus hispidus Say and Ord, three females (E. V. Komarek); Newton, May 24, 1937, on "wharf rat," numerous specimens (B. V. Travis); Valdosta, December 20, 1935, on "Rattus alexandrinus," male, two females; November 29, 1935, on "roof rat," female (H. Hixson). IOWA-Ames, September 27, 1934, on "cottontail rabbit," three males, three females (E. F. Knipling). LOUISIANANew Orleans, on "rats," two females (Hobenhoffer). MARYLAND-Berwyn, "in flour," July, 1937, male, two females; Baltimore, on Rattus norvegicus (Erxleben), numerous specimens. RHODE ISLAND - Providence, November 27, several specimens (S. H. Robinson). 
EAstern hosts. House-mouse ("Mus domestica"), House-rat (Rattus norvegicus (Erxleben)), Roof-rat ("Rattus alexandrinus"), Black Rat ("Rattus rattus"), Cotton-rat (Sigmodon hispidus hispidus Say and Ord), "Cottontail Rabbit," "Man."

Eastern localities. District of Columbia, Florida, Georgia, Illinois, Indiana, Iowa, Louisiana, Maryland, Massachusetts, Minnesota, New York, North Carolina, Ohio, Pennsylvania, Rhode Island, Virginia.

Type material. A large series of both sexes from Shendi, Egypt, on "Acomys witherbyi," "Gerbillus robustus," "Arvicanthis testicularis," "Dipodillus watersi," "Dipus jaculus," and "Genetta dongolana" in the N. C. Rothschild Collection (British Museum).

This species resembles in superficial structure Pulex irritans Linnaeus, but may be distinguished readily from it by the arrangement of the head bristles, the presence of a divided mesosternite, and the character of the genitalia. These points of difference are illustrated in Plate $V$.

By far the most important species in our fauna from the medical standpoint is the oriental rat flea which is known to transmit bubonic plague and endemic typhus fever, and is suspected of being among the transmitters of the causative agents of several other diseases. For many years it was known in the United States only from the large port cities. Its occurrence in the interior was not made known until 1925 when it was mentioned in a report of the State Entomologist of Indiana (Wallace, 1925), as occurring on rats in Indianapolis. Although some further records of the species from the interior have been made, it is known to be permanently established only at Ames, Iowa.

\section{PULEX LINNAEUS}

Pulex Linnaeus, 1758, Systema Natura. 10th Ed., p. 614.

\section{Genotype: Pulex irritans Linnaeus}

No genal or pronotal ctenidium present. Ocular bristle situated near the middle or below the middle of the eye. Mesosternite not divided by a vertical rodlike sclerotization.

This genus is represented in the East by a single species which sometimes becomes a nuisance to man and domesticated animals. 


\author{
Pulex irritans Limnaeus \\ (Plate V, figs. 17, 19, 21)
}

1758 Pulex irritans Linnaeus, Systema Naturae, p. 614.

1761 Pulex irritans Linnaeus, Fauna Suecica, No. 1965. p. 479.

1895 Pulex irritans Baker, Can. Ent., 27:67.

1896 Pulex irritans Osborn, United States Dept. Agric. Div. Ent., Bull. V (n.s.), p. 147, fig. 80.

1904 Pulex irritans Baker, Proc. United States Nat. Mus., 27:379, Pl. XI, figs. 3-6.

1905 Pulex irritans Baker, Proc. United States Nat. Mus., 29:129.

1910 Pulex irritans C. Fox, United States Public Health and Mar. Hosp. Ser., Bull. 30, p. 142, Pl. V, figs. 1-4.

1914 Pulex irritans C. Fox, United States Public Health Ser. Hyg. Lab., Bull. 97, Pl. XIV, fig. 21; Pl. XXI, fig. 64.

1925 Pulex irritans C. Fox, Insects and Disease of Man, p. 132, fig. 60.

1928 Pulex irritans Stewart, Cornell Univ. Agric. Exp. Sta., Mem. 101, p. 868.

1929 Pulex irritans Jordan, Nov. Zool., 35:176.

1929 Pulex irritans Ewing, Manual External Parasites, p. 164, fig. 91.

1931 Pulex irritans Ewing, Amer. Nat., 65:363.

1933 Pulex irritans Stewart, Jour. New York Ent. Soc., 41: 254.

1934 Pulex irritans Shaftesbury, Jour. Elisha Mitchell Sci. Soc., 49: 250.

Male. Preantennal region of the head with but two long bristles, one situated near the eye, the other at the base of the maxilla. Dorsal region of the head with numerous minute setae. First antennal segment with three or four bristles of various sizes; second antennal segment with five or six long bristles. Mandible distinctly serrated. Labial palpus reaching beyond one-half the length of the anterior coxa. A series of small setae situated posterior to the third antennal segment; remainder of the postantennal region with but a single bristle. Each segment of the thorax with a row of bristles consisting of alternating long and short bristles. Modified segments: Clasper with two movable processes arranged to form pincers; about these processes is a broad conspicuous flap supplied with numerous slender curved bristles along the margins. Posterior movable process of the clasper with four or five small bristles; anterior process without distinct bristles. Manubrium rather short, distally curved and finger-like. Penis not wide, blunt and rounded anteriorly; spring long, completing at least one turn. For further details concerning the structure of the male genitalia, see Plate V, fig. 17.

FEMale. Chaetotaxy of the head (Plate V, fig. 21) and general structure essentially as in the male. Sternite VII without 
a distinct sinus. Head of the receptaculum seminis round, tail finger-like, somewhat wider distally than proximally. For further details concerning the structure of the female genitalia, see Plate V, fig. 19.

RECORDS. ARKANSAS-Imboden, 1928, no host given, two females (B. C. Marshall). DISTRICT OF COLUMBBIA-Washington, June 13, 1933, on "woman" (C. Ford). FLORIDALittle River, November 30, 1912, no host given, numerous specimens (Knab and Mosier); same locality, December 20, 1913, on "man," male (C. A. Mosier). GEORGIA-Griffin, April 25, 1935, on "dog," two females (T. L. Bissell). ILLINOIS -Elmwood, July 2, 1914, on "hogs," numerous specimens (J. M. Morey). INDIANA-Frankfort, April 29, 1914, no host given, four males, two females (Mrs. F. R. Davis). IOWAFairfield, April, 1934, no host given, male and female (C. J. Drake); Ottumwa, July, 1931, on "man," female, two males (G. Hazen); Henry County, May 21, 1936, no host given, male (M. Jaques); Lineville, December, 1936, on Vulpes regalis Merriam, numerous specimens (E. Sanders). LOUISIANATallulah, July 1, 1929, collected by airplane, 200 feet, female (P. A. Glick). MARYLAND-Laurel, June 16, 1931, on "dog," male, two females (E. B. Marshall). MISSOURI-Columbia, June 20, 1932, in "house," female; May 24, 1937, on "hogs," male and female (L. Haseman); Gilliam, August, 1914, on "man," numerous specimens (A. Cramer). NEW JERSEY - New Brunswick, September 18, 1916, on "dog," female. NORTH CAROLINA-Halifax, August 14, 1931, on "dog," two females; July 10, 1935, on same host, female (E. B. Marshall). PENNSYLVANIA-Oxford, June, 1912, in "house," male, three females (Mrs. W. R. Woolf); Chaddis Ford, April, 1921, no host given, several specimens (W. W. Betts). VIRGINIA - South Richmond, July 6, 1914, no host given, numerous specimens (Mrs. E. A. Hawthorn) ; Blacksburg, October, 1938, on "hogs," numerous specimens (J. M. Grayson).

EASTERn Hosts. "Man," "Dog," "Hog," "Cottontail Rabbit," "Cat," "Gray Squirrel," Opossum ("Didelphis virginiana"), Rabbit ("Lepus species"), Red Fox (Vulpes regalis Merriam).

Eastern localities. Arkansas, District of Columbia, Florida, Georgia, Illinois, Indiana, Iowa, Louisiana, Maryland, Massachusetts, Michigan, Mississippi, Missouri, Nebraska, New Jersey, New York, North Carolina, Ohio, Oklahoma, Pennsylvania, Texas, Virginia.

Type material. From man, the type locality apparently 
Sweden. ("Habitat in hominibus, praesertim feminis, autumno vulgaris; in nidis hirundinum ripariarum copiosissima. In Lapponia non vidi.") Location of type not ascertained.

Although Pulex irritans probably occurs in every state of the Union, it is seldom found in large cities and is doubtless absent from many forested and swamp areas. Man, dogs, and hogs seem to be its most favored hosts.

CEDIOPSYLLA JORDAN

Cediopsylla Jordan, 1925, Nov. Zool. 32:103.

\section{Genotype: Pulex simplex Baker}

Ocular bristle placed higher than the eye. Frons angulate in front, with a distinct incrassation. Genal ctenidium obliquely vertical, consisting of straight robust blunt spines. Pronotal ctenidium present.

This genus is represented in the East by a single species which is an important parasite of rabbits.

\section{Cediopsylla simplex (Baker)}

(Plate III, figs. 6, 7, 10)

1895 Pulex inaequalis var. simplex Baker, Can. Ent., 27:164.

1896 Pulex inaequalis var. simplex Osborn, United States Dept. Agric. Div. Ent., Bull. V, p. 153, fig. 84.

1904 Ctenocephalus simplex Baker, Proc. United States Nat. Mus., 27:385.

1905 Spilopsyllus simplex Baker, Proc. United States Nat. Mus., 29:131.

1925 Cediopsylla simplex Jordan, Nov. Zool., 32: 103.

1928 Spilopsyllus simplex Stewart, Cornell Univ. Agric. Exp. Sta., Mem. 101, p. 868.

1928 Cediopsylla simplex Jordan, Nov. Zool., 34:182.

1929 Cediopsylla simplex Jordan, Nov. Zool., 35: 176.

1933 Cediopsylla simplex Stewart, Jour. New York Ent. Soc., 41:254.

1928 Spilopsyllus cuniculi Schwartz and Shook, United States Dept. Agric., Farm. Bull. 1568, p. 10.

1934 Cediopsylla simplex Shaftesbury, Jour. Elisha Mitchell Sci. Soc., 49: 252.

1937 Cediopsylla simplex Jordan, Nov. Zool., 40: 283.

Male. Head angulate. Frons with a long, rounded, dorsally directed incrassation. Preantennal region of the head with two long bristles and numerous small setae. Genal ctenidium consisting of eight spines. Mandible broad, prominent, deeply serrated, reaching to four-fifths the length of the anterior coxa. First segment of the antenna with about seven subapical bristles; second antennal segment similarly armed but the 
bristles longer. Postantennal bristles arranged in three irregular rows; first row consisting of two or three bristles, the second of two, and the third of four or five. Pronotum with a single row of bristles and a ctenidium of six or seven spines on a side. Meso- and metanotum each armed with a single row of bristles. Modified SEgments: Clasper with two movable processes which, together with the apical portion of the posterior arm of sternite IX, are more or less enclosed in a membranous flap the margin of which is dorsally provided with hairlike setae. Anterior movable process of the clasper more or less straight, about as long as the curved posterior process; the latter with five or six small bristles along the posterior margin. Manubrium finger-like, its termination rounded. Penis bladelike, broader distally than posteriorly; spring long and prominent, but not completing a single turn in the specimens examined. Posterior arm of sternite IX broadly expanded apically where it is armed with a conspicuous patch of dark setae. Sternite VIII tapering to a point apically where it is curved outward and armed with three or four bristles on the outer margin. For further details concerning the structure of the male genitalia, see Plate III, fig. 7.

Female. Chaetotaxy of the head (Plate III, fig. 10) and general structure essentially as in the male. Mandible longer than in the male, reaching beyond the apex of the fore coxa. Sternite VII without a distinct sinus. Head of the receptaculum seminis slightly longer than broad, much broader than the tail. For further details concerning the structure of the female genitalia, see Plate III, fig. 6.

RECORDS. ARKANSAS-Imboden, March, 1925, on "rabbit," male, three females (B. C. Marshall). CONNECTICUT-No specific locality, September 3, 1936, on "New England cottontail," male, four females (J. E. Shillinger). DISTRICT OF COLUMBIA-Washington, January 29, 1931, on "cottontail," male (Alva Nye). FLORIDA-Monticello, May 2, 1937, on Lynx rufus floridanus (Rafinesque), male and female (E. V. Komarek). GEORGIA-Four miles west of Folkstown, April 13, 1936, on Sylvilagus floridanus mallurus (Thomas), two males (F. Harper) ; Newton, April 28, 1937, on same host, two females; April 1, 1937, on Vulpes fulva (Desmarest), male and female; July 26, 1937, on "wharf rat." two females (B. V. Travis). IOWA-Osceola, December 21, 1935, on "cottontail rabbit," female; August 3, 1936, on "rabbit," male and female (G. S. Cantonwine); Ames, November 5, 1934, on "cottontail 
rabbit," male and female; November 14, 1934, on same host, female, two males (E. V. Knipling); Waukon, November 12, 1937, on Blarina brevicauda brevicauda (Say), male (T. Scott); Lineville, December, 1936, on Vulpes regalis Merriam, male and three females (E. Sanders); Boone, November, 1938, in scat of same host, female (T. Scott); Mt. Pleasant, November 28, 1927, male and female, no host given (McCrory) ; Story City, December 10, 1938, on Sylvilagus species, numerous specimens (B. B. Morgan). MARYLAND - Silver Spring, June 26, 1938, on "cat," male (P. W. Oman); Bowie, April 12, 1924, on Sylvilagus floridanus mallurus (Thomas), six specimens (A. Hassall); Montgomery County, October 30, 1928, on "cottontail rabbit," female (E. Francis) ; Plummer Island, August 5, 1915, on "man" (H. S. Barber). MASSACHUSETTS-W. Tisbury, on Sylvilagus transitionalis (Bangs), June 9, 1936, two females (F. C. Bishopp) ; Needham, March 17, 1927, on same host, female, two males (J. D. Smith) ; Harvard, April 11, 1912, on "cottontail rabbit," female (J. L. Peters); Hardwich, December 15, 1926, on "wildcat," female (F. E. Beissig). NEW JERSEY-Burlington County, April, 1934, on "cottontail rabbit," female (R. J. Sim). NORTH CAROLINA-Halifax, February 15, 1936, on "cottontail rabbit," male, two females; December 11, 1935, on same host, female, two males; January 11, 1936, on same host, two females (E. B. Marshall); Pisgah National Forest, Asheville, May 11, 1936, on "gray fox," male and female (F. J. Ruff); March 11, 1936, on "raccoon," male and female (J. H. Stone). TENNESSEE-Greenbriar, April 1, 1931, on Sylvilagus floridanus mallurus (Thomas), four females; Smoky Mountains, March 30, 1931, on same host, male, three females (R. L. Boke). VIRGINIA-Hawlin, December, 1922, on "rabbit," nine specimens (M. T. Van Horn) ; Elliott Knobb, May 30, 1934, on "cottontail rabbit," male (A. H. Howell) ; Clifton, June 11, 1933, "in net sweepings," female (J. C. Bridwell); East Falls Church, May 24, 1925, on "rabbit," female (E. A. Chapin). WISCONSIN -Babcock, October 10, 1932, on Canis latrans Say, female (J. W. Schmidt).

EASTERN HOSTS. Bobcat (Lynx rufus floridanus (Rafinesque)), Cottontail Rabbit, (Sylvilagus floridanus mallurus (Thomas), etc.), Red Fox (Vulpes fulva (Desmarest), etc.). Short-tailed Shrew (Blarina brevicauda brevicauda (Say)), Coyote (Canis latrans Say), "Cat," "Gray Fox," "Raccoon," "Wharf-rat," "Man."

Eastern localities. Arkansas, Connecticut, District of Co- 
lumbia, Florida, Georgia, Iowa, Maryland, Massachusetts, New Jersey, North Carolina, Tennessee, Virginia, Wisconsin.

Type material. Male holotype on "Lepus species" from Michigan in the United States National Museum.

\section{CTENOCEPHALIDES STILES AND COLLINS}

Ctenoceplatides Stiles and Collins, 1930, United States Public Health Rep., 45:1308 (new name for Cienocephalus Kolenati, preoccupied).

\section{Genotype: Pulex canis Curtis}

Both a genal and a pronotal ctenidium present. Genal ctenidium more or less horizontal, consisting of long sharp spines. Frontal incrassation distinct. Ocular bristle placed on a level with or above the eye.

This genus is represented in the East by two exceedingly common species, the dog flea and the cat flea. Typical forms of these two species may be separated by the following key:

\section{Key to the Eastern Species of Ctenocephalides}

First genal spine much shorter than the second; head about one and onehalf times as long as high ................................ First genal spine about as long as the second or only slightly shorter; head about twice as long as high $\ldots \ldots \ldots \ldots \ldots \ldots \ldots \ldots \ldots$ felis

\section{Ctenocephalides felis (Bouché)}

(Plate VI, figs. 22, 23, 25)

1835 Pulex felis Bouché, Nov. Act. Acad. Leop. Carol.. 17:505.

1901 Pulex felis Rothschild, Ent. Rec., 13:126, Pl. III, fig. A.

1905 Pulex felis Rothschild, Nov. Zool., 12:192, fig. B.

1910 Ctenocephalus felis Banks, United States Public Health and Mar. Hosp. Ser., Bull. 30, p. 75.

1925 Ctenocephalus felis C. Fox, United States Public Health Rep., 40:1917.

1925 Ctenocephalus felis C. Fox, Insects and Disease of Man, p. 136.

1928 Ctenocephalus felis Stewart, Cornell Univ. Agric. Exp. Sta., Mem. 101, p. 868.

1929 Ctenocephalus felis Ewing, Manual External Parasites, p. 165, figs. $89,92$.

1929 Ctenocephalus felis Jordan, Nov. Zool., 35: 176.

1930 Ctenocephalides felis Stiles and Collins, United States Public Health Rep., 45: 1308.

1933 Ctenocephalides felis Stewart, Jour. New York Ent. Soc., 41:254.

1934 Ctenocephalides felis Shaftesbury, Jour. Elisha Mitchell Sci. Soc., 49: 252.

1937 Ctenocephalides felis Jordan, Nov. Zool., 40:283.

Male. Preantennal region of the head with but two bristles, one located near the eye, the other at the base of the third genal 
spine. Genal ctenidium consisting of seven or eight curved spines on a side; the first slightly smaller than the second, and the most posterior very small. First antennal segment with four or five bristles, second with six or seven bristles. Postantennal region of the head with two or three bristles in addition to the four or five that make up the marginal row (Plate VI, fig. 23). Pronotal ctenidium consisting of about eight spines on a side. Pronotum, meso-, and metanotum each armed with a single row of long bristles. ModfFied SEgments: Process of the clasper not distinct. Movable finger lobular, armed with numerous bristles along the margins. Manubrium finger-like, somewhat wider distally than basally. Penis truncate, wide and heavy; spring not completing a single turn. For further details concerning the structure of the male genitalia, see Plate VI, fig. 25.

Female. Head longer and narrower than in the male (Plate VI, fig. 22). Chaetotaxy of the head and general structure essentially as in the male. First genal spine as long as, or longer than, the second. Head of the receptaculum seminis half again as long as wide; much shorter than the tail.

Records. ALABAMA-Dale County, March 30, 1937, on "rabbit," female. CONNECTICUT-Storrs, no host given, male and female (J. A. Monter); Arcadia, October 24, 1913, on "cat," male and female (Bigelow). DISTRICT OF COLUMBIAWashington, July, 1912, no host given, female, two males (K. Knab) ; August 3, 1933, "in house," three females (A. Howell). FLORIDA-Orlando, May 28, 1922, on "man," male; Immokalee, February 7, 1937, on "raccoon," female (B. V. Travis). GEORGIA-Fort Valley, May 27, 1935, no host given, male, four females (O. I. Snapp); Savannah, June 25, 1935, no host given, female; Camden County, April 25, 1933, on "Urocyon cinereoargenteus," two females (F. Harper). IOWA - Iowa City, 1933, no host given, female; Sioux City, November 8, 1928, on "fur coat," male and female (C. N. Ainslie); Rogers, October 26, 1936, in "house," two males, two females: Nit. Pleasant, March 19, 1929, on "cat," two females (H. E. Jaques); Ames, October, 1938, on "dog," numerous specimons (H. H. Knight) ; December, 1933, on "cat," male, two females (R. L. Roudabush). ILLINOIS - Urbana, July 5, 1935, on "cat," three females (O. Mohr). LOUISIANA-New Orleans, August 20, 1917, no host given, male and female (H. E. Hubert); May 19, 1924, on "man," male (H. K. Plank); Jeanerette, on "dog," four females (Dikeman). MASSACHUSETTS-Am- 
herst, October, 1931, in "house," male, four females (A. J. Bourne): Springfield, July 24, 1903, two females (G. D. Dimmock) ; Framingham, October 1, 1934, on "man," female (C. A. Frost). MARYLAND-Cumberland, two females; Beltsville, August 9, 1937, on "cat," male and female (Billings). MISSOURI-Carson City, August, 1936, on "cat" (E. Sanders). NEW JERSEY-Moorestown, no host given, female (J. L. King). NEW YORK-Caroline, July 18, 1934, on "man," male (A. Stone) ; Ithaca, December 14, 1910, on "cat," two females (H. E. Ewing). OHIO-Brunswick, May 27, 1929, on "cat and man," male and female; Akron, September 18, 1936, in "lumber yard," two males, two females (H. Graves). PENNSYLVANIA -Hazelton, July 1, 1937, on "man," two females (R. Morgan). RHODE ISLAND-Kingston, April, 1928, "from among pupal cases and cast off larval skins of gypsy moth," two females (A. E. Steene). SOUTH CAROLINA-Anderson, December, 1939, on "fox," two females (R. B. Casey). VIRGINIA-Hollins, on "cat," numerous specimens; Waverly, August 9, 1931, on same host, male, two females (E. B. Marshall).

EASTERN Hosts. "Cat," "Dog," "Rabbit," "Man," "Rats," "Raccoon," "Opossum," "Flying Squirrel," Red Squirrel ("Sciurus hudsonicus"), Skunk ("Spilogale ambarvalis").

EASTERn localities. Generally distributed throughout the inhabited areas of the East.

TYPe MATERIAL. From "housecat"; type locality not given. Location of type not ascertained.

\section{Ctenocephalides canis (Curtis)}

(Plate VI, figs. 24, 26, 27)

1826 Pulex canis Curtis, British Entomology, Vol. III, No. 114, figs. A-E, 8. 1895 Pulex scrraticeps Baker, Can. Ent., 27:164.

1896 Pulex serraticeps Osborn, United States Dept. Agric. Div. Ent., Bull. V (n.s.), p. 150, fig. 83.

1901 Pulex canis Rothschild, Ent. Rec., 13:126, Pl. III, figs. B-C.

1904 Ctenocephalus canis Baker, Proc. United States Nat. Mus., 27:384.

1905 Pulex canis Rothschild, Nov. Zool., 12:192, fig. A.

1905 Ctenocephalus canis Baker, Proc. United States Nat. Mus., 29:131.

1910 Ctenocephalus canis C. Fox, United States Public Health and Mar. Hosp. Ser., Bull. 30, p. 143, Pl. VI, figs. 1-4.

1925 Ctenocephalus canis C. Fox, United States Public Health Ser., Rep. 40: 1917.

1925 Ctenocephalus canis C. Fox, Insects and Disease of Man, p. 135, fig. 63.

1928 Ctenocephalus canis Stewart, Cornell Univ. Agric. Exp. Sta., Mem. 101, p. 868.

1929 Ctenocephalus canis Ewing, Manual External Parasites, p. J.65.

1329 Ctenocephalus canis Jordan, Nov. Zool., 35:176. 
1930 Ctenocephalides canis Stiles and Collins, United States Public Health Ser., Rep. 45: 1308.

1933 Ctenocephalides canis Stewart, Jour. New York Ent. Soc., 41: 25t.

1934 Ctenocephalides canis Shaftesbury, Jour. Elisha Mitchell Sui. Soc., 49: 252.

The common occurrence of forms intermediate in structure between $C$. felis and C. canis make the two species exceedingly difficult to separate. The points of separation, as regards typical forms, are to be found particularly in the shape of the head and in the genal ctenidium. In $C$. canis the head is much rounder and higher than in $C$. felis and is about one and onehalf times as long as high (Plate VI, figs. 24, 26), while in the latter species the head is about twice as long as high. In $C$. canis the first genal spine is much shorter than the second, while in $C$. felis it is as long as, or at least not much shorter than, the second. The manubrium in the male of $C$. canis is much broader apically than proximally, while in C. felis this structure is only slightly expanded distally. The receptaculum seminis in the female of $C$. canis has essentially the same structure as that of C. felis (Plate VI, fig. 27).

RECORDS. ARKANSAS-Imboden, 1928, no host given, female (B. C. Marshall). DISTRICT OF COLUMBIA-Washington, July, 1931, in "house," male (J. G. Pratt). FLORIDATallahassee, June 14, 1936, on "gray fox," three males. GEORGIA-Fort Valley, May 28, 1935, no host given, male (O. I. Snapp). ILLINOIS-Chicago, July 20, 1915, in "house," three males, three females (S. Lukes) ; Paris, November 28, 1937, no host given, numerous specimens; Egan, July 20, 1935, on "cat," two females, two males; Ottawa, November 7, 1935, in "house," male. IOWA - Sioux City, October 7, 1922, no host given, male (C. N. Ainslie) ; Ames, 1934, on "silver fox," two males, two females (E. F. Knipling); Lineville, December, 1936, on Vulpes regalis Merriam, male (E. Sander). INDIANA-Elkhart, on "cat," numerous specimens (R. J. Weith). MAINE-Camden. July 18, 1916, in "stable," numerous specimens (H. B. Foster). MARYLAND-Takoma Park, August, 1920, on "man," numerous specimens. MASSACHUSETTS-Wenham. May 14, 1926, on "woodchuck," two females (J. C. Phillips); South Swansea, in "house," male, four females (J. N. Sullivan). MICHIGANAlpena, September 27, 1909, on "dog." numerous specimens. MISSOURI-St. Louis, in "house," numerous specimens (T. Patterson). NORTH CAROLINA-Pisgah National Forest. Asheville, May 11, 1936, on "gray fox," female (F. J. Ruif). 
NEW HAMPSHIRE-Canobie Lake, July, 1892, on "cat," female (G. Dimmock). NEW JERSEY-Rivertown, June 25, 1934, in "grass," male, three females (M. R. Osburn); Hammonton, "in house," numerous specimens. NEW YORK-Middletown, numerous specimens (C. C. Young). OHIO - Akron, September 18, 1936, two females, two males (H. Graves). PENNSYLVANIA - Scranton, October, 1912, in "house," male, two females (D. H. Edelsohn). VIRGINIA-Richmond, August, 1937, in "house," two males (E. B. Marshall); Lynchburg, July 22, 1935, no host given, three males (M. G. Perron).

EAstern hosts. "Dog," "Cat," "Rabbit," "Rats," "Gray Fox," "Man," "Woodchuck," Red Fox (Vulpes regalis Merriam).

EAstern localities. Generally distributed throughout the inhabited areas of the East.

Type material. No type host or locality given. Location of type not ascertained. 


\section{FAMILY DOLICHOPSYLLIDAE BAKER}

1905 Dolichopsyllinae Baker, Proc. United States Nat. Mus., 29:127.

1909 Dolichopsyllidae Oudemans, Nov. Zool., 16:156.

1915 Ceratophyllidae Rothschild, Ent. Mo. Mag., 51:58.

1926 Ceratophyllidae Dampf, Ent. Mitt., 15:380.

1929 Dolichopsyllidae Ewing, Manual External Parasites, p. 165.

1936 Ceratophyllidae Wagner, Tierwelt Mitteleuropas, Bd. 6, Abt. 17, s. 4.

In this family there are two or more rows of bristles on each abdominal tergite. The eye is well developed except in Conorhinopsylla and Foxella where it is vestigial. A pronotal ctenidium is present in all cases except in Rhopalopsyllus and Trichopsylla where both the genal and pronotal ctenidium are absent. Two genera, Ctenophthalmus and Rectofrontia are armed with both a pronotal and a genal ctenidium.

This family is the largest in our fauna and in the East is represented by fourteen genera which are rather difficult to separate. Until 1933 many of the separate genera now recognized were included in the complex Ceratophyllus. The name Ceratophyllus is now limited to a large group whose members are normally parasitic only on birds.

Key to the Eastern Genera of Dolichopsyllidae

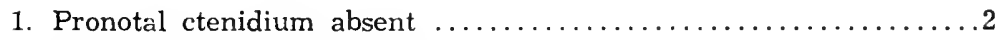

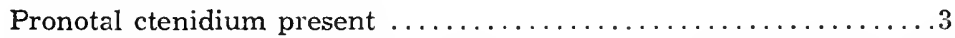

2. Ocular row consisting of three bristles .........Rhopalopsyllus, p. 30

Ocular row consisting of four bristles ........... Trichopsylla, p. 32

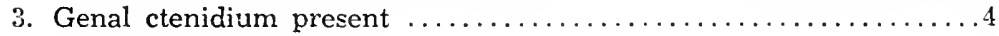

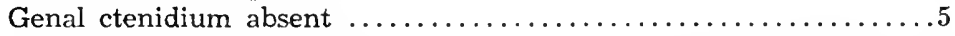

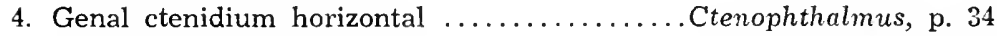

Genal ctenidium vertical $\ldots \ldots \ldots \ldots \ldots \ldots \ldots \ldots$ Rectofrontia, p. 38

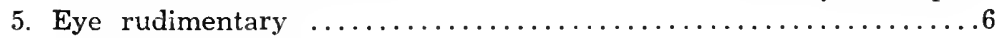

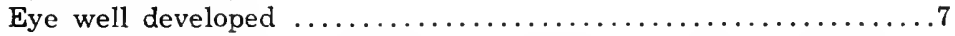

6. Pronotal ctenidium consisting of about ten slender spines on a

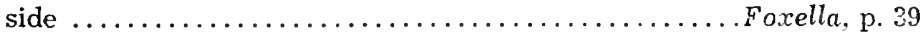

Pronotal ctenidium consisting of six broad spines on a side ........

.Conorhinopsylla, p. 41

7. Labial palpus extending beyond the apex of the fore coxa by about

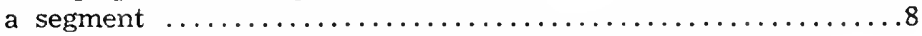

Labial palpus not extending beyond the apex of the fore coxa or extending only slightly beyond $\ldots \ldots \ldots \ldots \ldots \ldots \ldots \ldots \ldots \ldots$ 
8. Frontal tubercle pominent. Females with two antepygidial bristles Opisocrostis, p. 42

Frontal tubercle small and acuminate. Females with three antepygidial bristles ..................... Oropsylla, p. 44

9. Fifth tarsal segment of each leg armed with four pairs of lateral plintar bristles and a basal ventral pair ................. 10

Fifth tarsal segment of each leg armed with five pairs of lateral piantar bristles (the basal pair may be slightly displaced toward the median

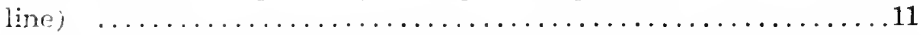

10. Postantennal region armed with one or no bristles in addition to those of the marginal row. Frontal tubercle small ...... Opisodasys, p. 56

Postantennal region armed with two or three bristles in addition to those of the marginal row. Frontal tubercle large, Orchopeas, p. 58

11. Pronotal ctenidium consisting of twelve or more spines on a side ..12

Pronotal ctenidium consisting of less than twelve spines on a side ..13

12. Head of the receptaculum seminis globular; movable finger as wide as long $\ldots \ldots \ldots \ldots \ldots \ldots \ldots \ldots \ldots \ldots \ldots$ Odontopsyllus, p. 46

Head of the receptaculum seminis not globular; movable finger longer

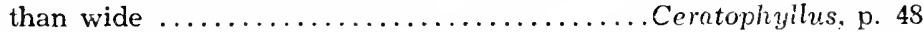

13. Movable finger with spiniforms; tail of the receptaculum seminis not long and not curved about head ...............Megabothris, p. 67

Movable finger without spiniforms; tail of the receptaculum seminis long and curved about head ................. Nosopsyllus, p. 73

\section{RHOPALOPSYLLUS BAKER}

Rhopalopsyilus Baker, 1905, Proc. United States Nat. Mus., 29:128.

\section{Genotype: Pulex lutzii Baker}

Genal and pronotal ctenidium absent. Frontal tubercle large and conspicuous, acuminate, directed dorsad. Two large bristles on the gena below the eye. Postantennal region of the head with three rows of bristles. Posterior margin of the antennal groove with a dense row of short spiniform bristles. One long antepygidial present on a side. Fifth tarsal segment armed with four pairs of lateral plantar bristles and an apical submedian pair.

This genus is represented in the East by a single species which may have been introduced into this country from South or Central America by rats. It is now well established in our southern states.

Rhopalopsyllus gwyni C. Fox

(Plate VII, figs. 28, 32, 33)

1914 Rhopalopsyllus gwyni C. Fox, United States Public Health Ser. Hyg. Lab., Bull. 97, p. 10, Pl. III. figs. 1-6.

1923 Rhopalopsyllus gwyni Jordan and Rothschild, Ectoparasites, 1:333. 1932 Rhopalopsyllus gwyni Jordan, Nov. Zool., 38:292. 
MaLE. Preantennal region of the head with two rows of bristles and a series of small setae along the anterior margin of the antennal groove. Upper row consisting of six bristles of which the one closest to the antenna is small and weak while the other five are longer and more robust. Lower row with three long stout bristles. Eye large, heavily pigmented, and prominent. Labial palpus not reaching to the apex of the fore coxa. Postantennal region of the head with three rows of bristles, the first consisting of five stout bristles, the second of six, and the third of seven which alternate with small setae (Plate VII, fig. 28). Pro- and mesonotum each armed with two rows of bristles. Metanotum armed with three rows of bristles. Each abdominal tergite with two rows of bristles. Tibia and tarsus of the hind legs richly supplied with stout bristles. ModIFIED SEGMENTS: Clasper heavy, roughly quadrangular. the dorsal margin armed with a number of heavily pigmented bristles of various sizes. Movable finger curved, with a number of small setae on the margins. Manubrium finger-like, much shorter than the penis, blunt terminally. Penis broad and heavy, terminating bluntly; the spring short, not completing a single turn. Posterior arm of sternite IX with numerous bristles apically. For further details concerning the structure of the male genitalia, see Plate VII, fig. 32 .

Female. General structure and chaetotaxy essentially as in the male, except that the labial palpus extends beyond the fore coxa. Posterior margin of sternite VII rounded, without a sinus. Head of the receptaculum seminis slightly longer than broad; tail longer than the head. For further details concerning the structure of the female genitalia, see Plate VII, fig. 33.

RECORDS. FLORIDA-Osceola County, January 5, 1937, on "opossum," two males (B. V. Travis) ; Fort Lauderdale, February 18, 1919, on "Oryzomys palustris (Harlan)," female (A Wetmore) ; Tallahassee, January 21, 1937, on "cotton rat," two males, two females. GEORGIA - Thomasville, July-August, 1934, on Sigmodon hispidus hispidus Say and Ord, numerous specimens; Grady County, August 16, 1934, on "cotton rat," two females; Newton County, July 8, 1936, on "Didelphis virginiana," female (E. V. Komarek). LOUISIANA-Jeanerette, February 2, 1929, on "opossum" (Dikeman).

EASTERN Hosts. Opossum ("Didelphis virginiana"), Rice-rat ("Oryzomys palustris (Harlan)"), Cotton-rat (Sigmodon hispidus hispidus Say and Ord), "Rats."

EAstern localities. Florida, Georgia, Louisiana. 
Type material. Male and female from Brunswick, Georgia, on "rats" in the United States National Museum.

This species was once thought to be a synonym of the South American Rhopalopsyllus bohlsi (Wagner) but is now regarded as distinct.

\section{TRICHOPSYLLA (KOLENATI) JORDAN AND ROTHSCHILD}

Trichopsylla Kolenati, 1863, Hor. Soc. Ent. Ross., 2: 32.

Trichopsylla Jordan and Rothschild, 1920, Ectoparasites, 1:63.

Genotype: Vermipsylla homoeus Rothschild

Genal and pronotal ctenidium absent. Eye well developed. Ocular row consisting of four bristles. Frontal tubercle large and conspicuous. Antepygidial bristles absent. Fifth tarsal segment of each leg armed with four pairs of lateral plantar bristles.

This genus is represented in the East by two species which may be separated by the following key.

Key to the Eastern Species of Trichopsylla

Middle of the three rows of bristles on the postantennal region consisting of three bristles ..................................... lotoris

Middle of the three rows of bristles on the postantennal region consisting of five bristles $\ldots \ldots \ldots \ldots \ldots \ldots \ldots \ldots \ldots \ldots \ldots \ldots \ldots \ldots \ldots \ldots$ floridensis

\section{Trichopsylla floridensis I. Fox}

(Plate VIII, figs. 34, 36, 39)

1939 Trichopsylla floridensis I. Fox, Proc. Ent. Soc. Washington, 41:45, Pl. 6, fig. 6.

MALE. Preantennal region of the head with two rows of bristles; the upper row consisting of six, the lower row consisting of four much stouter ones arranged in an oblique line. Genal process heavily pigmented and pointed. First segment of the antenna with numerous small setae in a longitudinal row; apically with eight or nine larger setae in a transverse row of about eight small setae and several long bristles about as long as the third segment. Postantennal region armed with three irregular rows of bristles; the first consisting of three stout bristles, the second of five, and the third or marginal row of about nine long bristles which alternate with about seven small setae. Labial palpus reaching to about two-thirds the length of the fore coxa. Dorsal region of the head and thorax with a conspicuous pubescence. Pronotum with a marginal row of 
about eight bristles. Meso- and metanotum each with two irregular rows of bristles. IVtetepimeron armed on its posterior margin with about six long bristles anterior to which is an irregular row of five or six shorter ones (Plate VIII, fig. 36). Each abdominal tergite with two rows of bristles, the posterior made up of long bristles reaching to the middle of the next segment. Modified segments: Clasper broad and flat, the margins with numerous long bristles. Process of the clasper not distinctly separated from the body proper. Movable finger long and curved. Manubrium finger-like, ending bluntly. Penis blunt terminally; spring not completing a turn. For further details of the male genitalia, see Plate VIII, fig. 39 .

Female. Chaetotaxy of the head (Plate VIII, fig. 34) and general structure essentially as in the male except that the pubescence on the head and thorax is absent. Tail of the receptaculum seminis longer than the head which is oval and longer than wide. Genitalia essentially as in T. lotoris Stewart (Plate VIII, fig. 38).

EASTERN HOST. Unknown.

EASTERN LOCALITY. Florida.

Type material. Two males and two females from "garden truck leaf mold" at Gainesville, Florida, in the United States National Museum.

Trichopsylla lotoris Stewart

(Plate VIII, figs. 35, 37, 38; Plate IX, fig. 42)

1926 Trichopsylla lotoris Stewart, Insec. Insc. Menst., 14:122, 1 textfig.

1928 Trichopsylla lotoris Stewart, Cornell Univ. Ag. Exp. Sta., Mem. 101, p. 869.

1929 Trichopsylla lotoris Jordan, Nov. Zool., 35:176.

1933 Trichopsylla lotoris Stewart, Jour. New York Ent. Soc., 41: 258.

MaLE. Chaetotaxy of the head differing from that of $T$. floridensis in several noteworthy respects. Upper of the two preantennal rows of bristles consisting of three bristles rather than six, the middle of the three postantennal rows with three bristles rather than five. Metepimeron without a row of five or six bristles anterior to the marginal row (Plate VIII, fig. 37). ModifIED SEGMENTS: Clasper narrower than in T. floridensis and very different in general shape. Manubrium much narrower, tapering to a blunt point. For further details concerning the structure of the male genitalia, see Plate IX, fig. 42.

Female. General structure and chaetotaxy of the head essentially as in the male (Plate VIII, fig. 35). For details con- 
cerning the structure of the female genitalia, see Plate VIII, fig. 38 .

Reconds. IOWA - Clayton County. March 27, 1939, on Procyon lotor lotor (Linnaeus), male (B. B. Morgan). MAINE -Lucerne-in-Maine. November 1, 1928, on same host, female (F. Harper). NORTH CAROLINA-Pisgah National Forest, March 2, 1936, on "raccoon," female (J. H. Stone).

EASTERN hOST. Raccoon (Procyon lotor lotor (Linnaeus)). Eastern localities. Iowa, Maine, New York, North Carolina.

Type material. Male and female from Olcott, New York, on Procyon lotor lotor (Linnaeus) in the Cornell University Collection.

\section{CTENOPHTHALMUS KOLENATI}

Ctenophthalmus Kolenati, 1856, Die Parasiten der Chiropteren, p. 33.

Genotype: Ctenophthalmus bisoctodentatus Kolenati

Frontal tubercle prominent, acuminate, projecting far beyond the anterior border of the head. Eyes vestigial. Genal ctenidium consisting of three spines. Labial palpus not extending beyond the apex of the fore coxa; the distal segment armed with a curved apical bristle. Fifth tarsal segment of the fore and middle legs armed with four pairs of lateral plantar bristles and a basal and a distal submedian pair. Fifth tarsal segment of the hind legs armed with three pairs of lateral plantar bristles and a basal and a distal submedian pair. Three antepygidial bristles present on a side, the middle the longest and the lowermost much longer than the uppermost.

This genus is represented in the East by a single species which is exceedingly common on various small mammals.

\section{Ctenophthalmus pseudagyrtes Baker}

(Plate X, figs. 45, 46, 49)

1904 Ctenophthalmus pseudagyrtes Baker, Proc. United States Nat. Mus., 27: 421, Pl. XI, figs. 7-12.

1895 Typhlopsylla assimilis Baker, Can. Ent., 27:190 (not T. assimilis Taschenberg).

1896 Typhlopsylla assimilis Osborn, United States Dept. Agric. Div. Ent., Bull. 5, p. 153, fig. 85 (not T. assimilis Taschenberg).

1898 Typhlopsylla assimilis Baker, Jour. New York Ent. Soc., 6:55 (not T. assimilis Taschenberg)

1904 Ctenophthalmus pseudagyrtes Rothschild, Nov. Zool., 11:641, Pl. XIV, figs. 73, 78; Pl. XV, fig. 81.

1905 Ctenophthalmus pseudagyrtes Baker, Proc. United States Nat. Mus., 29: 135 . 
1914 Ctenophthalmus pseudagyrtes C. Fox, United States Public Health Ser. Hyg. Lab., Bull. 97, Pl. XVI, fig. 28; Pl. XX, fig. 61.

1925 Ctenophthalmus pseudagyrtes C. Fox, United States Public Health Ser., Rep. 40 (3) : 1922.

1928 Ctenophthalmus pseudagyrtes Stewart, Cornell Univ, Agric. Exp. Sta. Bull., Mem. 101, p. 869.

1928 Ctenophthalmus pseudagyrtes Jordan, Nov. Zool., 34:186.

1929 Ctenophthalmus pseudagyrtes Jordan, Nov. Zool., 35: 171.

1930 Ctenophthalmus pseudagyrtes Jordan, Trans. IV Intern. Congress Ent. (1928), p. 493, fig. 1.

1933 Ctenophthalmus pseudagyrtes Stewart, Jour. New York Ent. Soc., 41: 258 .

1933 Ctenophthalmus pseudagyrtes Jordan, Nov. Zool., 39:62.

1934 Ctenophthalmus pseudagyrtes Shaftesbury, Jour. Elisha Mitchell Sci. Soc., 49: 254.

1937 Ctenophthalmus pseudagyrtes Jordan, Nov. Zool., 40: 285.

MALE. Preantennal bristles of the head arranged in two rows, the upper with five bristles, the lower with three much longer ones. Three spines of the genal ctenidium obliquely directed posteriorly; the first the shortest, the second somewhat wider than the other two, and the third the longest and most acuminate. Maxilla long, tapering to a long slender point. Numerous small setae along the posterior margin of the antennal groove. Postantennal bristles usually arranged in three irregular rows of which the first consists of two bristles, the second of three, and the third of five to seven (Plate X, fig. 45). Pronotum armed with a single row of alternating long bristles and weak setae, and a ctenidium of six or seven spines on a side. Mesonotum armed with three or four irregular rows of bristles. Metanotum and each abdominal tergite armed with two or three rows of bristles. Some of the abdominal tergites further armed with a short stout dorsal tooth on a side. Modified SEGMents: Process of the clasper bifurcate, the posterior lobe extending further dorsad than the anterior, and curved anteriorly, the posterior margin armed with a stout bristle; anterior lobe armed distally with four or five stout bristles. Movable finger long and broad, curved anteriorly, armed with four or five short bristles on the posterior margin and a number of short hairlike setae (Plate X, fig. 49). Manubrium short and broad, tapering to a curved point extending anteriorly as far as, or further than, the penis. Penis slender, not tapering to a long point; spring short, not completing a turn.

Female. Chaetotaxy and general structure essentially as in the male. Head of the receptaculum seminis much longer than 
wide, tail much shorter than the head. For further details concerning the structure of the female genitalia, see Plate $X$, fig. 46 .

REcords. ALABAMA-Dale County, April 5, 1937, on "wood rat," female (R. E. Dyer). DISTRICT OF COLUMBIABrookland, November, 1912, in "nest of mole," numerous specimens. GEORGIA - Thomasville, December 5-6, 1937, on "Pitymys pinetorum," male and female (Komarek and Travis); February 8, 1937, in nest of Peronyscus polionotus polionotus (Wagner), female (E. V. Komarek). INDIANA-Chesterton, June 8, 1935, on Scalopus aquaticus machrinoides Jackson, female, two males (R. Komarek). IOWA-Osceola, August 23, 1935, on "field mouse," two males; July 15, 1934, on "mole," two males, two females; July 24, 1935, on "cottontail rabbit," two females (G. S. Cantonwine); Ames, July 4, 1936, nest of "Blarina brevicauda." numerous specimens; July, 1934, on "Citellus tridemlineatus," female (R. L. Roudabush); Ruthven, June-July, 1938, on Microtus pennsylvanicus pennsylvanicus (Ord), female (E. R. Becker and P. C. Waters). MARYLAND -Burnt Mills, March 24 and 29, 1932, on "pine mouse," numerous specimens; same date and locality, on "Blarina brevicauda," female, two males; Chillum, May 17, 18, 1932, on "pine mouse," female, two males (R. Greenfield); Plummer Island, September 3. 1921, in nest, probably of "Scalopus aquaticus," female; same locality, May 2, 1927, on "young Microtus," male and female (H. S. Barber); Silver Springs, February 23, 1932, on "pine mouse," six males (R. Greenfield); same locality, April 25, 1928. on "Blarina brevicauda," male and female (Ewing and East); College Park, May, 1929, on "pine mouse," four males (H. E. Ewing and H. S. Peters); Beltsville, May 10, 1935. on Scalopus aquaticus aquaticus (Linnaeus), female (T. Lehto). MASSACHUSETTS-Fall River, June 7, 1936, on Perornyscus leucopus noveboracensis (Fischer), female (F. C. Bishopp); Edgartown, September 22, 1937, on Peromyscus leucopus fusus Bangs, female (C. N. Smith); same locality, June. 1936, on Microtus pennsylvanicus pennsylvanicus (Ord), numerous specimens (F. C. Bishopp and C. N. Smith); West Tisbury, June 9, 1936, on Blarina brevicauda aloga Bangs, male (F. C. Bishopp); Squibnocket, June 11, 1936, on "Microtus pennsylvanicus," female (C. N. Smith); Newton Center, January 28, 1926, on Blarina brevicauda talpoides (Gapper), male (F. Harper); Scraggy Neck, June 18, 1936, on Microtus pennsylvanicus pennsylvanicus (Ord), female (C. N. Smith). MINNESOTA-Cloquet, September 12, 1933, on "Blarina brevi- 
cauda." female. NEW HAMPSHIRE-Concord, June 14, 1927, on Parascalops breweri (Bachman), male (F. B. White). NEW YORK-Ithaca, April 6, 1936, on Microtus pennsylvanicus pennsylvanicus (Ord), male (W. J. Hamilton); Adirondack Lodge, Essex County, July 31, 1925, on Tamias striatus lysteri (Richardson), female (F. Harper); Long Lake, July 25, 1926. on "Sciurus hudsonicus," male (R. T. Hatt). NORTH CAROLINA-Oconalufty, April 18, 1931, on "Microtus montanus," three females (R. L. Boke). OHIO-Fairfield County, April 2, 1935, on Blarina brevicauda talpoides (Gapper), female (R. Goslin). VIRGINIA-Fall's Church, on "Scalopus aquaticus," two males; East Fall's Church, August 20, 1919, "runway of field mouse," male (H. E. Ewing); Prospect Hill, in "field mouse nest," two females (W. M. Mann); Petersburg, April 6, 1933, on "Albemarle meadow mouse," two males, two females (H. S. Peters); Winchester, October, 1922, on "skin of Microtus pennsylvanicus," female (E. A. Chapin).

Eastern Hosts. Hairy-tailed Mole (Parascalops breweri (Bachman)), Mole (Scalopus aquaticus aquaticus (Linnaeus), etc.), Short-tailed Shrew (Blarina brevicauda talpoides (Gapper), etc.), Star-nosed Mole (Condylura cristata (Linnaeus)), Musk-rat (Ondatra zibethica zibethica (Linnaeus)), Whitefooted Mouse (Peromyscus leucopus noveboracensis (Fischer), etc.), Meadow-mouse (Microtus pennsylvanicus pennsylvanicus (Ord)), Pine-mouse ("Pitymys pinetorum"), House-mouse ("Mus musculus"), Red-backed Mouse ("Evotomys gapperi"), Wood-rat (Neotoma pennsyivanicus Stone), Red Squirrel ("Sciurus hudsonicus"), Flying Squirrel (Glaucomys volans volans (Linnaeus)), House-rat (Rattus norvegicus (Erxleben)), Chipmunk (Tamias striatus lysteri (Richardson)), Pocket Gopher (Geomys bursarius (Shaw)), "Cottontail Rabbit," Thirteen-striped Ground Squirrel ("Citellus tridecemlineatus"), Skunk ("Mustela frenata"), Screech Owl ("Megascops asio").

Eastern localities. Alabama, District of Columbia, Georgia, Indiana, Iowa, Maryland, Massachusetts, Michigan, Minnesota, New Hampshire, New York, North Carolina, Ohio, Pennsylvania, Virginia.

Type material. Female from Agricultural College, Michigan. on "mole" (according to the slide), and a female from Ames, Iowa, on "Scalops argentatus" in the United States National Museum.

This species is one of the most abundant of the flea parasites 
of small mammals. It very frequently occurs in company with Doratopsylla blarinae C. Fox as a parasite of shrews, but the mole is probably its most favored host.

\section{RECTOFRONTIA WAGNER AND ARGYROPOLO}

Rectofrontia Wagner and Argyropolo, 1934, Zeitschr. Parasit., 7: 230.

Genotype: Typhlopsylla pentacanthus Rothschild

Anterior border of the head produced into a prominent tooth. Eye vestigial. Genal ctenidium consisting of four to six spines. Ocular row made up of two bristles. Labial palpus five-segmented. Males without antepygidial bristles, females with two or three on a side. Fifth tarsal segment of each leg armed with four pairs of lateral plantar bristles, without a basal submedian pair.

This genus is represented in the East by a single species which is parasitic on various small mammals.

\section{Rectofrontia fraterna (Baker)}

(Plate X, figs. 44, 47, 48)

1895 Typhlopsylla fraterna Baker, Can. Ent., 27:189.

1904 Ctenophthalmus fraternus Baker, Proc. United States Nat. Mus.. $27: 423$.

1905 Ctenophthalmus fraternus Baker, Proc. United States Nat. Mus., 29: 135.

1913 Rhadinopsylla fraterna Rothschild, The Entomologist, 46:297.

1937 Rectofrontia fraterna Jordan, Nov. Zool., 40:270.

MALE. Bristles of the preantennal region of the head arranged in two rows. Upper row consisting of five or six bristles of which the one closest to the antennal groove is the weakest; lower row consisting of two long, stout bristles. Postantennal region armed with three rows of bristles of which the most anterior consists of four bristles, the middle of five, and the most posterior or marginal row of seven or eight. Spines of the genal ctenidium variable in number, when five are present they are arranged as in Plate X, fig. 44, the middle three being longest. Pronotum with a single row of alternating short and long bristles and a ctenidium of ten or eleven spines on a side. Meso- and metanotum each armed with two rows of bristles anterior to which there may be another row consisting of two or three bristles. Each abdominal tergite with two rows of bristles. Some of the abdominal tergites further armed with two to four teeth on a side. Modified SEgments: Process of the 
clasper wide and heavy, more or less triangular. Movable finger narrower, with the outer margin convex, and the inner concave. Manubrium short and wide tapering to a point. Penis broad and bladelike; spring short, not completing a turn. For further details concerning the structure of the male genitalia, see Plate X, fig. 47.

Female. Chaetotaxy of the head and general structure essentially as in the male (Plate X, fig. 44). Sternite VII without a sinus, its posterior margin irregular. Receptaculum seminis distorted in the specimens available. For further details concerning the structure of the female genitalia, see Plate X, fig. 48 .

RECORD. MARYLAND-Kensington, February 22, 1924, on "Microtus pennsylvanicus," male (H. S. Barber) (the genal ctenidium of this specimen consists of four spines on one side and five on the other).

EASTern Host. Meadow-mouse ("Microtus pennsylvanicus"). (Known from various small mammals in the West.)

EASTERN LOCALITIES. Maryland, South Dakota (Montana, Wyoming, Canada).

Type material. Female holotype from Brookings, South Dakota, host unknown, and male specimen from Kensington, Maryland, described above, in the United States National Museum.

\section{FOXELLA WAGNER}

Foxella Wagner, 1930, Konowia, 8: 314.

Genotype: Pulex ignotus Baker

Eye rudimentary. Ocular row consisting of four to six bristles, the ocular bristle situated well above the eye rudiments. Pronotal ctenidium consisting of ten or eleven spines on a side. Females with three antepygidial bristles on a side, of which the middle is the longest and the uppermost the shortest. Males with one long and one short antepygidial bristle on a side. Other details essentially as in Ceratophyllus Curtis.

This genus is represented in the East by a single species whose favorite host seems to be the pocket gopher. So far it has not been found further east than Illinois.

\section{Foxella ignotus (Baker)}

(Plate XI, figs. 52, 54, 55)

1895 Pulex ignotus Baker, Can. Ent., 27:110.

1895 Typhlopsylla americana Baker, Can. Ent., 27:189. 
1896 Typhlopsylla americana Osborn, United States Dept. Agric. Div. Ent.,

Bull. V (n.s.), p. 154, figs. $86,87$.

1904 Ceratophyllus ignotus Baker, Proc. United States Nat. Mus., 27:416, Pl. XXI, figs. 1-6.

1905 Ceratophyllus igmotus Baker, Proc. United States Nat. Mus., 29:134.

1914 Ceratophyllus ignotus C. Fox, United States Public Health Ser. Hyg.

Lab., Bull. 97, Pl. XII. fig. 16.

1915 Ceratophyllus ignotus Joidan and Rothschild, Ectoparasites, 1:54. fig. 57.

1929 Ceratophyllus ignotus ignotus Jordan, Nov. Zool., 35:32.

1930 Ceratophyllus ignotus Jordan, Trans. IV Intern. Cong. Ent. (1928), p. 498, figs. 10,11 .

1930 Foxella ignotus Wagner, Konowia, 8:314.

1933 Foxella ignotus Jordan, Nov Zool., 39: 75.

1938 Foxella ignotus ignotus Jordan, Nov. Zool., 41:123, figs. 74, 75.

MaLE. Preantennal region of the head armed with two rows of bristles, each consisting of four to six. Genal process sharply pointed. Labial palpus reaching to or almost to the apex of the fore coxa. A series of about twelve small bristles along the posterior edge of the antennal groove. Postantennal region armed with one stout bristle located near the second antennal segment below which are one or two shorter ones, and a marginal row of six to eight long bristles (Plate XI, fig. 55). Pronotum with a row of alternating long and short bristles and a ctenidium of ten or eleven spines on a side. Meso- and metanotum each with two rows of bristles. Each abdominal tergite similarly armed, the bristles long and conspicuous. Modified SEGMENTS: Process of the clasper more or less triangular, armed at the apex with three bristles. Movable finger long, armed with four long bristles and several shorter ones on the posterior margin. Penis long and wide, terminating in a long curved process; spring long but not completing a turn. Sternite VIII with a long, curved, heavily pigmented bristle. For further details concerning the structure of the male genitalia, see Plate XI, fig. 54.

Frmale. Chaetotaxy of the head and general structure essentially as in the male. Stemite VII with a deep sinus. Fead of the receptaculum seminis spherical, much wider than the tail (Plate XI, fig. 52).

Reconds. IOWA-Ames, August 8, 1937, on Geomys bursarius (Shaw), three males, three females; Jewell. September 29, 1938, on Scalopus aquaticus machrinus (Rafinesque), male; Dubucue, November 2, 1937, on Peromyscus leucopus noveboracensis (Fischer), male (T.Scott): November 11,1934.on same 
host, two males, three females (E. F. Knipling). MINNESOTA -St. Paul, on "pocket gopher," two males.

EAstern Hosts. Pocket Gopher (Geomys bursarius (Shaw)), White-footed Mouse (Peromyscus leucopus noveboracensis (Fischer)), Mole (Scalopus aquaticus machrinus (Rafinesque)).

EASTERn Localities. Illinois, Iowa, Minnesota.

Type material. Female holotype from Ames, Iowa; male and female from Fort Collins, Colorado, (as Typhlopsylla americana), and a male from Ames, Iowa, (as Typhlopsylla americana), in the United States National Museum.

\section{CONORHINOPSYLLA STEWART}

Conorhinopsylla Stewart, 1930, Can. Ent., 62:178, P1. 15, figs. 3-5.

Genotype: Conorhinopsylla stanfordi Stewart

Frontal notch absent. Eye rudimentary. Frontogenal angle of the head extended to form a protuberance. Maxilla broad, triangular, not ending in a long point. Pronotal ctenidium consisting of about six unusually broad and heavily pigmented spines on a side. Segments I and II of the hind tarsus of the male with long hairlike bristles. Fifth tarsal segment of each leg with four pairs of lateral plantar bristles and a basal submedian pair.

This genus is represented in the East by a single species which is parasitic on squirrels. It has also been found in the West.

\section{Conorhinopsylla stanfordi Stewart}

(Plate XXVIII, figs. 148, 149, 150)

1930 Conorhinopsylla stanfordi Stewart, Can. Ent., 62:178, Pl. 15, figs. 3-5. 1933 Conorhinopsylla stanfordi Stewart, Jour. New York Ent. Soc., 41:257. 1937 Conorhinopsylla stanfordi Jordan, Nov. Zool., 40:267, figs. 51-53.

Female. Bristles of the preantennal region of the head arranged in two rows; the lower row consisting of two to four bristles of various lengths of which the third is the longest: upper row indefinite consisting of about four small bristles. Labial palpus six-segmented, extending beyond the trochanters. A number of small setae along the posterior margin of the antennal groove. Postantennal region of the head with a slender bristle near the first antennal joint, a much stouter one near the base of the third antennal segment and a marginal row of four or five bristles of which the most ventral is the longest 
(Plate XXVIII, fig. 148). Pronotum armed with a single row of bristles and a ctenidium of about six spines on a side. Meso- and metanotum and each abdominal tergite armed with a posterior row of unusually long bristles anterior to which there may be another row of much shorter bristles. Anterior tergites further armed with one to four short stout dorsal teeth on a side. Three antepygidial bristles present on a side of which the middle is longest. Sternite VII without a sinus. Head of the receptaculum seminis very large, about twice as long as wide, much longer than the tail. For further details concerning the structure of the female genitalia, see Plate XXVIII, fig. 149.

Male. General structure essentially as in the female. Two of the three antepygidial bristles aborted. Modified segments: Sternite VII and posterior arm of sternite IX so close together as to give the impression of two processes of a single structure. The former with four spiniform bristles at the apex. Clasper projecting above the dorsal margin of the abdomen, its process hidden by the wide, diamond-shaped movable finger. Manubrium broad, ending in a curved point. Penis broad and terminating bluntly; spring not long and not completing a turn. For further details concerning the structure of the male genitalia, see Plate XXVIII, fig. 150.

Records. IOWA-Luxemburg, November 13, 1937, two females; November 23, 1937, on Glaucomys volans volans (Linnaeus), two females (T. Scott). (UTAH-Salina, May 29, 1929, on "Citellus mollis," male.)

EASTERN HOSTS. Red Squirrel ("Sciurus hudsonicus"), Gray Squirrel ("Sciurus carolinensis"), Flying Squirrel (Glaucomys volans volans (Linnaeus)).

EAstern localities. Illinois, Iowa, New York, (Utah).

TyPe Material. Two males and two females from "Sciurus hudsonicus" in addition to the holotype in the Collection of Dr. M. A. Stewart.

\section{OPISOCROSTIS JORDAN}

Opisocrostis Jordan, 1933, Nov. Zool., 39: 73.

Genotype: Ceratophyllus hirsutus Baker

Frontal tubercle prominent, extending beyond the anterior margin of the head. Labial palpus reaching well beyond the apex of the fore coxa. Bristles of the second antennal segment very long. Pronotal ctenidium consisting of eight or nine spines 
on a side. Males with one long antepygidial bristle and one or two minute ones; females with two antepygidial bristles of which the lower is the shorter. Other structural details essentially as in Ceratophyllus Curtis.

This genus is represented in the East by a single species which occurs rather commonly on ground squirrels.

\section{Opisocrostis bruneri (Baker)}

(Plate XI, figs. 50, 51, 53)

1895 Pulex bruneri Baker, Can. Ent., 27:131.

1896 Pulex bruneri Osborn, United States Dept. Agric. Div. Ent., Bull. V (n.s.), p. 149, fig. 82.

1898 Pulex bruneri Baker, Jour. New York Ent. Soc., 6: 55.

1904 Ceratophyllus bruneri Baker, Proc. United States Nat. Mus., 27:413, PI. XXV, figs. 1-5.

1905 Ceratophyllus brineri Baker, Proc. United States Nat. Mus., 29: 135.

1914 Ceratophyllus bruneri C. Fox, United States Public Health Ser. Hyg.

Lab., Bull. 97, Pi X, fig. 9; Pl. XVII, fig. 35.

1930 Oropsylla bruneri Wagner, Konowia, 8:313.

1933 Opisocrostis bruneri Jordan, Nov. Zool., 39:73.

MALE. Preantennal region of the head with two rows of bristles; lower row with three robust bristles, upper row with one to three much more slender ones. Posterior margin of the antennal groove with a series of small setae. Postantennal region armed with a marginal row of four or five bristles and one or two stout bristles near the second and third antennal segments (Plate XI, fig. 50). Pronotum with a single row of alternating stout and weak bristles. Mesonotum armed with two or three rows of bristles; metanotum armed with about five rows. Each abdominal tergite with two rows of bristles. Metanotum and the anterior three or four abdominal tergites each armed with one or two short stout dorsal teeth on a side. Modified SEgments: Process of the clasper more or less rounded, not prominent, moundlike, with three slender bristles apically and two stouter ones at the side. Movable finger large and heavy, anterior margin concave, posterior margin with one long bristle and five or six shorter ones distally. Manubrium curved, finger-like, blunt distally. Penis broad, ending in a very short process; spring long but barely completing a single turm. For further details concerning the structure of the male genitalia, see Plate XI, fig. 51.

FEMALE. Chaetotaxy of the head and general structure essentially as in the male. Head of the receptaculum seminis more or less rounded, much wider than the long tail. For 
further details concerning the structure of the female genitalia, see Plate XI, fig. 53.

RECORDS. ILLINOIS-Lamont. April 22, 1935, on "Citellus tridecemlineatus." male and female (R. Komarek); Savoy, April 23, 1933, on "Citellus franklini," male, two females; Urbana, April 10, 1934, on "Citellus tridecemlineatus," female, two males; Rock Island, June 8, 1932, on same host. male (Ross and Mohr) ; Aledo, May 8, 1932, on same host, female (H. Ross). IOWA-Ames, July, 1935, on "Franklin's ground squirrel," male and female; July, 1935, on "13-striped ground squirrel," three males, three females (R. L. Roudabush); same locality, May 1, 1938, on "gray squirrel," male and female (Mahoney); Luxemburg, November 23, 1937, on Glaucomys volans volans (Linnaeus), female (T. Scott); Ruthven, July, 1938, on "13striped ground squirrel," numerous specimens (E. R. Becker and P. C. Waters); Lake Okoboji, August 15, 1916, on same host, male (L. L. Buchanan). MINNESOTA-Rapidan, 1937. no host given, male, eight females (W. P. Mohr). WISCONSIN -Kenosha, October 8, 1936, on "Citellus tridecemlineatus," male, two females ( $R$. Komarek).

EASTERN HOSTS. Thirteen-striped Ground Squirrel ("Citellus tridecemlineatus"), Franklin's Ground Squirrel ("Citellus franlitini"), "Gray Squirrel," Flying Squirrel (Glaucomys volans volans (Linnaeus)).

EAstern localities. Illinois, Iowa, Minnesota, Nebraska, Wisconsin, (Idaho, Colorado).

Type material. Two females from Lincoln, Nebraska, female from Fort Collins, Colorado, and a male from Ames, Iowa, in the United States National Museum.

\section{OROPSYLLA WAGNER}

Oropsylla Wagne: and Ioff, 1926, Rev. Microbiol. and Epidemiol., 5:86.

\section{Genotype: Ceratophyllus silanticwii Wagner}

Frontal tubercle small and acuminate. Labial palpus long. extending beyond the apex of the coxa by more than a segment. Pronotal ctenidium consisting of about nine spines on a side. Other general siructural details as in Ceratophyllus Curtis. Movable finger of the males with long bristles but without spiniforms.

This genus is represented in the East by a single species which has the woodchuck as its normal host. 


\section{Oropsylla arctomys (Baker)}

(Plate IX, figs. 40, 41, 43)

1904 Cerctophyllus arctomys Baker, Proc. United States Nat. Mus., 27:583. 1905 Cerctophyllus arctomys Baker, Proc. United States Nat. MIus. 29:134. 1928 Ceratophyllus arctomys Stewart, Cornell Univ. Agric. Exp. Sta., Iem. 101, p. 869.

1928 Ceratophyllus arctomys Jordan, Nov. Zool., 34:183.

1929 Ceratophyllus arctomys Jordan, Nov. Zool., 35: 176.

1929 Oropsylla arctomys Wagner, Konowia, 8:315.

1933 Oropsylla arctomys Stewart, Jour. New York Ent. Soc., 41: 258.

1933 Oropsylla arctomys Jordan, Nov. Zool., 39: 73.

1937 Oropsylla arctomys Jordan, Nov. Zool., 40:284.

MaLe. Preantennal region of the head armed with two rows of bristles, each consisting of three. A number of small setae near the anterior and posterior margins of the antennal groove. Posterior margin of the head armed with three or four bristles; one located at the lower angle, the other two or three situated dorsad. Postantennal region further armed with a robust bristle situated near the second antennal joint. Pronotum with a single row of alternating long bristles and weak setae. Mesoand metanotum each armed with two rows of bristles anterior to which there may be several other bristles. Metanotum and anterior abdominal tergites further armed with one or two stout dorsal teeth on a side. Each abdominal tergite with two rows of bristles. Modified SEgmants: Process of the clasper broad and lobular, its dorsal margin armed with three or four slender bristles. Movable finger large, convex at both margins, the posterior margin armed with four or five bristles. Manubrium short, ending in a curved point. Penis broad and heavy, terminating in a slender curved process; spring long, completing a turn. Sternite VIII armed with five or six stout bristles on the posterior margin and two or three curved bristles apically. For further details concerning the structure of the male genitalia, see Plate IX, fig. 40.

Female. General structure and chaetotaxy of the head essentially as in the male (Plate IX, fig. 41). Sternite VII without a deep sinus. Head of the receptaculum seminis longer than wide, longer than the tail. For further details concerning the female genitalia, see Plate IX, fig. 43.

RECORDS. CONNECTICUT-No specific locality, July, 1892, on "woodchuck," male; Monroe, on same host, two females, two males (G. Dimmock). IOWA-Ames, July, 1935, on "woodchuck," two males, five females (R. L. Roudabush); Jewell, 
September, 1937, on "Mephitis sp.," four males. five females (T. Scott); Mt. Pleasant. December 25, 1937, on "badger," female, two males (H. E. Jacques). MASSACHUSETTS-A bington, April 12, 1924, on "woodchuck," male (T. D. Smith); Charles River Village, June 13, 1928, on Marmota monax preblorum Howell, female (F. Harper); Holbrook, May 13, 1924, on "woodchuck," male and female; Needham, March 26, 1927, on same host, male and female (T. D. Smith); Newton Center, September 20, 1926, on "Arctomys monax," male and female (F. Harper). MINNESOTA-Cloquet, September 4, 1936, on "Marmota monax," female; Thief Lake, March 29, 1937, on "woodchuck," six females, three males (K. Krumm). NEW HAMPSHIRE-Concord, May 15, 1926, on "red fox," female (F. B. White). NEW JERSEY-Vincentown, June 4, 1934, in "skunk nest," two males, two females (R. J. Sim). NEW YORK-Keesville, May 29, 1918, on "Marmota monax," male and female (N. Dearborn); North Elba, July 17, 1926, on same host, female (F. Harper).

EASTERN HOSTS. Woodchuck (Marmota monax preblorum Howell, etc.), Red Squirrel (Sciurus hudsonicus loquax Bangs), "Opossum," Skunk (Mephitis nigra (Peale and Beauvois)), White-tailed Deer (Odocoileus virginianus borealis Miller), Gray Fox ("Urocyon cineroargenteus"), "Red Fox," Barred Owl ("Syrnium nebulosum").

Eastern localities. Connecticut, Iowa, Massachusetts, New Hampshire, New Jersey, New York, Pennsylvania.

TyPe Material. Male and female from "Arctomys monax" at Peterboro, New York, in the United States National Museum.

\section{ODONTOPSYLLUS BAKER}

Odontopsyllus Baker, 1905, Proc. United States Nat. Mus., 29: 129.

\section{Genotype: Pulex multispinosus Baker}

Frontal tubercle prominent, acuminate. Eye large, pigmented heavily at the margins. Labial palpus reaching almost to the apex of the fore coxa. Pronotal ctenidium consisting of fourteen to nineteen long spines on a side. Females with three antepygidial bristles present on a side of which the lowermost is well separated from the other two. Anterior margin of the hind coxa armed with numerous small bristles. Other details essentially as in Ceratophyllus Curtis.

This genus is represented in the East by a single species which parasitizes rabbits in particular. 
Odontopsyllus multispinosus Baker

(Plate VII, figs. 29, 30, 31)

1898 Pulex multispinosus Baker, Jour. New York Ent. Soc., 6:54.

1904 Ceratophyllus multispinosus Baker, Proc. United States Nat. Mus., 27:389, Pl. XII, figs. 1-5.

1905 Odontopsyllus multispinosus Baker, Proc. United States Nat. Mus., 29: 131.

1928 Odontopsyllus multispinosus Jordan, Nov. Zool., 34: 185.

1929 Odontopsyllus multispinosus Jordan, Nov. Zool., 35:175.

1934 Odontopsyllus multispinosus Shaftesbury, Jour. Elisha Mitchell Sci. Soc., $49: 254$.

MaLE. Bristles of the preantennal region arranged in two rows. Upper row consisting of four to six bristles, lower row consisting of three much longer and more robust ones. Genal process prominent, acuminate. First antennal segment with numerous small setae, second antennal segment with five or six bristles which are not longer than the third joint. Numerous small setae located along the posterior margin of the antennal groove. Postantennal region armed with three bristles located in the region of the second antennal segment and a marginal row of about eight bristles of which two located at the lower angle are very stout and prominent. Pronotum with a posterior row of alternating weak setae and stout bristles, anterior to which there is a row of about three bristles. Middle region of the lower pronotum further armed with a long stout bristle. Meso- and metanotum each armed with three or four rows of bristles. Each abdominal tergite armed with two rows of bristles anterior to which there may be another row consisting of about three short bristles. The abdominal tergites further armed with one or two short, stout black teeth on a side. Modified SEgMents: Clasper more or less rectangular in shape, the process not distinctly set off from the remainder. Movable finger more or less quadrangular, armed with a number of bristles of various sizes along the margins. Most conspicuous among these are four, long. stout ones located ventrally. Manubrium tapering to a sharp point. Penis broad and heavy; spring short, not completing a single turn. Posterior arm of sternite IX expanded apically where it is armed with seven or eight short bristles. For further details concerning the structure of the male genitalia, see Plate VII, fig. 30 .

Female. Bristles of the upper preantennal row weaker than in the male (Plate VII, fig. 29). Sternite VII not divided by a deep sinus. Receptaculum seminis large and conspicuous, the 
head globular and striated. For further details concerning the structure of the female genitalia, see Plate VII, fig. 31.

Reconds. ALABAMA - Dale County, March 30, 1937, on "rabbit," female (R. E. Dyer). GEORGIA-Newton, April 28. 1937, on Sylvilagus floridanus mallurus (Thomas), male. IOWA-Osceola, December 16, 1935, on "cottontail rabbit," male (G. S. Cantonwine) ; Ames, May, 1933, on same host, two males, two females (R. L. Roudabush); Waukon, November 12. 1937. on Blarina brevicauda brevicauda (Say), female (T. Scott). MARYLAND-Bowie, December 4, 1924, on Syivilagus floridanus mallurus (Thomas), two females (A. Hassall). MASSACHUSET'TS-W. Tisbury, June 9, 1936, on Sylvilagus transitionalis (Bangs), male and female (F. C. Bishopp); Cohasset, February 29, 1924, on "cottontail rabbit," male and female (J. D. Smith); Harvard, April 11, 1912, on same host, male (J. L. Peters). NORTH CAROLINA-Halifax, January 11, 1936, on "cottontail," male (E. B. Marshall); Pisgah National Forest, March 8, 1936, on "bobcat," female; March 2, 1936, on "raccoon," female (J. H. Stone). SOUTH CAROLINA -Branchville, February 8, 1931, on "rabbit," female (W. E. Dove and Schroeder).

EASTERN HOSTS. Cottontail Rabbit (Sylvilagus floridanus mallurus (Thomas), etc.), Short-tailed Shrew (Blarina brevicauda brevicauda (Say)), "Bobcat," "Raccoon."

EAstern Localities. Alabama, Georgia, Iowa, Maryland, Massachusetts, North Carolina, South Carolina, Virginia.

Type material. Male holotype from Raleigh, North Carolina, on "Lepus sylvaticus" in the United States National Museum. Female allotype from Waukon, Iowa, on Blarina brevicauda brevicauda (Say), described above, in the Iowa State College Collection.

With Cediopsylla simplex (Baker), this species is one of the most abundant flea parasites of the rabbit.

\section{CERATOPHYLLUS CURTIS}

Ceratophyllus Curtis, 1832, British Entomology, 9:417.

Genotype: Ceratophyllus hirundinus Curtis

Eye well developed. Ocular bristle placed on a level with or above the upper margin of the eye. Preantennal region of the head with two rows of bristles of which the upper consists of three to six, while the lower consists of three much longer ones. Labial palpus not reaching beyond the apex of the fore 
coxa, usually about as long as the maxillary palpus. Pronotal ctenidium consisting of not less than twelve spines on a side. Males with one long antepygidial bristle and two minute ones on a side; females similarly armed or with three antepygidial bristles on a side of which the middle is the longest. Fifth tarsal segment of each leg armed with five pairs of lateral plantar bristles and an apical submedian pair.

This genus is represented in the East by seven closely related species all of which have various birds as their normal hosts. While these species are easily distinguished, the characters do not lend themselves well to a key. Males may be readily identified by the shape of the movable finger and the process of the clasper, and females by the form of sternite VII and of the receptaculum seminis. These structures are illustrated in Plates XII to XIV, to which the reader is referred.

\section{Ceratophyllus celsus Jordan \\ (Plate XII, figs. 56, 57)}

1926 Ceratophyllus celsus Jordan, Nov. Zool., 33: 387, fig. 3.

MALE. Upper row of the preantennal region consisting of three or four bristles and several small setae. A series of small setae situated along the anterior and posterior edges of the antennal groove. Postantennal region with three bristles, one much longer than the other two, and a marginal row of four or five bristles of which the most ventral is large and well developed. Pronotum with a single row of bristles and a ctenidium of about fourteen spines on a side. Mesonotum armed with four or five irregular rows of small bristles; metanotum with two or three irregular rows of small bristles. Each abdominal tergite armed with two or three irregular rows of bristles. Some of the abdominal tergites further armed with one to three stout teeth on a side. Modified segments: Process of the clasper long and narrow, at least three times as long as wide at the middle, armed with one long bristle and two much shorter ones at the apex. Movable finger similar in general structure to that of $C$. niger C. Fox; widest at about the middle where the anterior border is expanded to form a spinelike protuberance; armed on the posterior margin with two or three long bristles and several others of various sizes. Manubrium wide, terminating bluntly. Posterior arm of sternite IX with numerous short robust bristles distally. Sternite VIII armed with six or seven long bristles at the apex and two membranous projections. Penis long and tapering to a fine curved point; spring long and 
conspicuous, completing one or two turns. For further details concerning the structure of the male genitalia, see Plate XII, fig. 56 .

Female. General structure essentially as in the male. Sternite VII usually without a distinct sinus, and the posterior border not divided into lobes. Head of the receptaculum seminis slender, more than twice as long as the tail. For further details concerning the structure of the female genitalia, see Plate XII, fig. 57.

RECoRDS. NEW YORK - Altamount, June-July, 1936, in "northern cliff swallow's nest," numerous specimens; Oneida Lake, July 23, 1931, on "cliff swallows," male; Troy, June 2, 1935, two females; July 1, 1935, on same host, female (D. Stoner).

Eastern host. "Northern Cliff Swallow."

EASTERN LOCALITY. New York.

TyPe Material. Male holotype from Okanagan Falls, British Columbia, on "Riparia riparia" in the N. C. Rothschild Collection (British Museum). Female allotype, described above, from Altamount, New York, in the United States National Museum.

\section{Ceratophyllus diffinis Jordan \\ (Plate XII, figs. 58, 59)}

1925 Ceratophyllus diffinis Jordan, Nov. Zool., 32:111, fig. 44.

1928 Ceratophyllus diffinis Jordan, Nov. Zool., 34:182, fig. 7.

1933 Ceratophyllus diffinis Jordan, Nov. Zool., 39: 75.

1935 Ceratophyllus rileyi Liu, Ann. Ent. Soc. America, 28:123, Pl. I, figs. $4,5,6$.

1937 Ceratophyllus diffinis Jordan, Nov. Zool., 40:263.

MaLe. Upper row of the preantennal region consisting of six or seven bristles, of which the anterior are quite long, while the others are reduced in size. Pronotum with a single row of bristles and a ctenidium of twelve spines on a side. Other details of general structure as in C. celsus and other species of the genus. Modified SEgments: Process of the clasper prominent, about twice as long as broad in the widest place; its apex provided with three bristles, of which the middle is the longest, while the other two are very short. Movable finger widest at the middle where the anterior border is not produced into a distinct spinelike protuberance. Posterior margin of the movable finger armed with three or four conspicuous long bristles and several smaller ones; anterior and dorsal borders armed 
with a number of small setae. Sternite VIII armed at the apex with two robust bristles on a side. Spring of the penis not long, not completing a single turn. For further details concerning the structure of the male genitalia, see Plate XII, fig. 59 .

Female. General structure essentially as in the male. Head of the receptaculum seminis broad, about as long as the tail. Sternite VII divided into two lobes by a broad sinus; the upper lobe acutely pointed and projecting slightly more distad than the lower lobe. For further details concerning the structure of the female genitalia, see Plate XII, fig. 58.

EAstern hosts. Ruffed Grouse ("Bonasa umbellus"), Catbird ("Galeoscoptis carolinensis"), Ovenbird (Seiurus aurocapillus (Linnaeus)), Veery (Hyclocichla fuscescens fuscescens (Stephens)), Robin (Planesticus migratorius migratorius L.), Bluebird (Sialia sialis siaiis (Linnaeus)), House-wren (Troglodytes aedon aedon Vieillot).

Eastern Localities. Massachusetts, Minnesota, New York, New Hampshire.

Type material. Male holotype from Okanagan Falls, British Columbia, on "Colymbus holboelli" in the N. C. Rothschild Collection (British Museum). A female paratype of C. rileyi Liu from Minnesota, a synonym, in the United States National Museum.

\section{Ceratophyllus idius Jordan and Rothschild}

(Plate I; Plate XII, figs. 60, 61)

1920 Ceratophyllus idius Jordan and Rothschild, Ectoparasites, 1:73, figs. $70,71,72$.

1928 Ceratophyllus idius Jordan, Nov. Zool., 34:183.

1933 Ceratophyllus idius Jordan, Nov. Zool., 39:75.

1937 Ceratophyllus idius Jordan, Nov. Zool., 40: 285.

Male. Chaetotaxy of the head as in C. diffinis. Pronotum armed with a single row of bristles and a ctenidium consisting of about sixteen spines on a side. General structure not differing in any noteworthy respects from the other species of the genus. Modified SEgments: Process of the clasper broad, rounded distally, about four-fifths as long as the movable finger, its apex armed with one robust bristle and several smaller ones. Movable finger three times as long as broad, the posterior margin strongly rounded apically, armed with three or four stout bristles and several smaller ones. Posterior border of sternite VIII with numerous weak bristles distally, the apex armed with two or three long stout bristles on a side. For further details 
concerning the structure of the male genitalia, see Plate I, and Plate XII, fig. 61.

Female. General structure and chaetotaxy as in the male. Head of the receptaculum seminis long and slender, much longer than the tail. Sternite VII divided into two lobes by a deep sinus, the upper lobe acutely pointed, the lower lobe variable in shape, its termination either pointed or rounded. For further details concerning the structure of the female genitalia, see Plate XII, fig. 60.

RECORDS. CONNECTICUT-Pomfret, June, 1933, in "tree swallow nest," numerous specimens (K. B. Wetherbee). ILLINOIS-Clarksville, January 5, 1933, in "bird nest," numerous specimens, (Frison and Ross). MAINE-No specific locality, July, 1930, in "swallow nest," male, two females (E. C. Grant). MARYLAND-Bell, September 23, 1926, in nest of "Progne subis," male, two females (W. L. McAtee); August 16, 1927, on "martin," male, two females (H. P. Sheldon). MASSACHUSETTS-Groton, June 14, 1933, in "nest of tree swallow," male and female (W. P. Wharton); Worcester, June 28, 1931, in "tree swallow nest," two males (Mrs. K. B. Wetherbee). MICHIGAN-McMillan, May 15, 1935, on "purple martin," female (O. M. Bryens).

EASTERN Hosts. Tree Swallow (Iridoprocne bicolor (Vieillot)), House-wren (Troglodytes aedon aedon Vieillot), Eastern Bluebird (Sialia sialis sialis (Linnaeus)), Purple Martin ("Progne subis").

Eastern localities. Connecticut, Illinois, Maine, Maryland, Massachusetts, Michigan.

Type material. Male and female from Okanagan Landing. British Columbia, in the N. C. Rothschild Collection (British Museum).

\section{Ceratophyllus gallinae (Schrank) \\ (Plate XIII, figs. 62, 63)}

1803 Pulex gallinae Schrank, Fauna Boica, 3:195.

1895 Pulex avium Baker, Can. Ent., 27:111.

1896 Pulex avium Osborn, United States Dept. Agric. Div. Ent., Bull. V (n.s.), p. 147

1920 Ceratophyllus gallinae Jordan and Rothschild, Ectoparasites, 1:70.

1924 Ceratophyllus gallinae Ewing, Parasitology, 16:342, Pl. XIV, fig. 1.

1927 Ceratophyllus gallinae Stewart, Jour. Econ. Ent., 20:132.

1928 Ceratophyllus gallinae Stewart, Cornell Univ. Agric. Exp. Sta., Mem. 101, p. 869.

1928 Ceratophyllus gallinae Garman, Connecticut Exp. Sta., Bull. 294, p. 279, Pl. XXIX, fig. B. 
1928 Ceratophyllus gallinae Jordan, Nov. Zool., 34:182.

1929 Ceratophyllus gallinae Jordan, Nov. Zool., 35:171.

1933 Ceratophyllus gallinae Jordan, Nov. Zool., 39: 75.

1933 Ceratophyllus gallinae Stewart, Jour. New York Ent. Soc., 41: 255.

1937 Ceratophyllus gallinae Jordan, Nov. Zool., 40: 285

Male. Chaetotaxy of the head and general structure essentially as in the other species of the genus. Pronotal ctenidium consisting of about fourteen spines on a side. ModIFIED SEGMENTS: Process of the clasper short, less than half as long as the movable finger; armed at the apex with one long bristle and two much shorter ones. Movable finger widest apically, where the anterior margin is concave, the posterior convex; posterior margin armed with three long bristles and several much shorter ones; anterior and dorsal margins armed with a number of small setae. Penis slender, terminating in a long curved process; spring long and conspicuous, completing one or two turns. For further details concerning the structure of the male genitalia, see Plate XIII, fig. 62.

Female. General structure and chaetotaxy essentially as in the male. Head of the receptaculum seminis wider and more prominent than in other species of the genus. Sternite VII without a sinus, the posterior margin convex. For further details concerning the structure of the female genitalia, see Plate XIII, fig. 63.

RECORDS. CONNECTICUT-Fairfield, August 16, 1916, in "stomach of Sturnus vulgaris," male and female; Pamfré, June, 1934, in "bluebird nest," female, three males (Mrs. K. B. Wetherbee). MAINE-Eliot, August 21, 1923, in "henhouse," two females (M. A. Stewart). MASSACHUSETTS-Boston, January, 1928, on "clothes in laboratory," three males, two females (M. Hertog). MICHIGAN-Sanilac County, November, 1925, in "poultry house," male, two females.

EAstern Hosts. "Man," English Sparrow (Passer domesticus domesticus Linnaeus), "Henhouse," Eastern Bluebird (Sialia sialis sialis (Linnaeus)). Tree Swallow (Iridoprocne bicolor (Vieillot)), Chipmunk ("Tamias striatus").

Eastern localities. Connecticut, Iowa, Maine, Massachusetts, Michigan, New York.

TYPE MATERIAL. Location of types not ascertained. "Wohnort: an Hühnen, Mausen, Fledermäusen, Maulwiirfen."

This species is quite capable of becoming a serious pest of chickens and has already caused damage during one or two outbreaks in our northeastern states. It may be immediately 
separated from the sticktight flea, Echidnophaga gallinacea, by the presence of a pronotal ctenidium.

\section{Ceratophyllus niger C. Fox}

(Plate XIII, figs. 64, 65)

1908 Ceratophyilus niger C. Fox, Ent. News, 19: 434.

1914 Ceratophyllus niger C. Fox, United States Public Health Ser. Hyg. Lab., Bull. 97, Pl. VII, fig. 2; Pl. XIX, fig. 46.

1920 Ceratophyllus niger Jordan and Rothschild, Ectoparasites, 1:70.

1924 Ceratophyllus niger Ewing, Parasitology, 16:343, Pl. XIV, fig. 1.

1928 Ceratophyllus niger Stewart, Cornell Univ. Agric. Exp. Sta., Mem. 101, p. 869.

1929 Ceratophyllus niger Jordan, Nov. Zool., 35:175.

1933 Ceratophyllus niger Jordan, Nov. Zool., 39:75

1933 Ceratophyllus niger Stewart, Jour. New York Ent. Soc., 41: 255.

MaLE. Upper row of the preantennal region armed with six bristles, of which two located near the antennal groove are much weaker than the others. Pronotum armed with thirteen or fourteen spines on a side. Other details of general structure as in other species of the genus. Modified SEgments: Process of the clasper roughly triangular in shape, as wide at the base as long, armed at the apex with one long bristle and two shorter ones. Movable finger wide distally where the anterior margin forms a spinelike protuberance; posterior margin armed with two or three stout bristles and several much weaker ones. Penis slender, ending in a curved process; spring very long, completing at least one turn. For further details concerning the structure of the male genitalia, see Plate XIII, fig. 64 .

Female. General structure and chaetotaxy essentially as in the male. Head of the receptaculum seminis slender, much longer than the tail. Sternite VII without a distinct sinus, its posterior margin convex. For further details concerning the structure of the female genitalia, see Plate XIII, fig. 65.

EASTERN HOST. Eastern Bluebird (Sialia sialis sialis (Linnaeus)) .

EASTERn Locality. New York.

Type material. Three females and two males on "Man" and one male on "Mus decumanus," locality not given. Location of the specimens not ascertained.

This species is not uncommon in the West where it is often taken from henhouses. The only record of its occurrence in the East was published by Stewart $(1928,1933)$. Jordan has doubted the record (1929), and until further discoveries are made, its presence in the East is questionable. The above 
descriptions and the accompanying figures were made from a male and a female taken from a chicken nest at Astoria, Oregon, (H. H. Stage).

\title{
Ceratophyllus riparius Jordan and Rothschild
}

\author{
(Plate XIII, figs. 66, 67)
}

1920 Ceratophyllus riparius Jordan and Rothschild, Ectoparasites, 1:71, figs. $67,68,69$.

1928 Ceratophyllus riparius Stewart, Cornell Univ. Agric. Exp. Sta., Mem. 101, p. 869.

1929 Ceratophyllus riparius Jordan, Nov. Zool., 35:177.

1933 Ceratophyllus riparius Stewart, Jour. New York Ent. Soc., 41:256.

1933 Ceratophyllus riparius Jordan Nov. Zool., 39:75.

MaLE. Upper of the preantennal rows armed with four to six bristles. Pronotum armed with about sixteen spines on a side. Other details of general structure essentially as in the other species of the genus. Modified SEgments: Process of the clasper more than three-fifths as long as the movable finger, blunt distally where it is armed with two or three short bristles. Posterior process of sternite IX armed distally with numerous heavily-pigmented bristles. Apex of sternite VIII armed with about eight stout bristles on a side. Penis slender, ending in a curved process; spring long but not completing a turn in the specimen described. For further details concerning the structure of the male genitalia, see Plate XIII, fig. 67 .

Female. General structure essentially as in the male. Receptaculum seminis similar to that of other species of the genus. Sternite VII divided by a deep sinus into two lobes, of which the lower is acutely pointed and projects further distad than the upper lobe (Plate XIII, fig. 66).

Reconds. MINNESOTA-No specific locality, May 29, 1930, on "bank swallow," female, two males. NEW YORK-West Albany, July 12 to 19,1933 , in "barn swallow burrow," three males (D. Stoner); Freeville, May 22, 1933, same host, two males, two females (W. J. Hamilton); Oneida Lake, May, June, and July, 1931, in "nests of bank swallows," numerous specimens (D. Stoner).

EASTERN HOSTS. Bank Swallow (Riparia riparia riparia Linnaeus), Belted Kingfisher ("Ceryle alcyon"), "Barn Swallow."

Eastern localities. New York, Wisconsin, Virginia.

Type material. A series from nest of "Riparia riparia" at Bay View, Milwaukee, Wisconsin, in the N. C. Rothschild Collection (British Museum). 
Ceratophyllus swansoni Liu

(Plate XIV, figs. 70, 71, 73)

1935 Ceratophyllus swansoni Liu, Ann. Ent. Soc. America, 28:121, Pl. 1, figs. 1-3.

1937 Ceratophyllus swansoni Jordan, Nov. Zool., 40:262, fig. 44.

MaLE. Upper row of the preantennal region consisting of four to eight bristles. of which four are robust and in line while the others are weak and more or less irregular in arrangement (Plate XIV, fig. 73). Pronotum armed with about fourteen spines on a side. Other details of general structure as in the other species of the genus. Modified segments: Somewhat similar in appearance to those of $C$. riparius but differing particularly in the shape of the process of the clasper which is triangular or conical, the apex blunt and armed with three bristles. Posterior margin of the movable finger rounded, armed with three stout bristles and several weaker ones. Sternite VIII armed at the apex with two or three stout bristles on a side. Penis slender, ending in a long curved process; spring long, completing one or two turns. For further details concerning the structure of the male genitalia, see Plate XIV, fig. 70 .

Female. General structure essentially as in the male. Head of the receptaculum seminis long and slender, much longer than the tail. Sternite VII without a sinus, broadly rounded posteriorly. For further details concerning the structure of the female genitalia, see Plate XIV, fig. 71.

EASTERn host. Long-eared Owl (Asio wilsonianus (Lesson)).

EASTERN localdty. Minnesota. (The above descriptions and the figures were made from a male and female specimen taken from the nest of Asio wilsonianus (Lesson) at Beaverhead County, Montana, (W. L. Jellison).)

Type material. Male holotype from Fertile, Minnesota, on Asio wilsonianus (Lesson) in the University of Minnesota Collection. Female allotype bearing the same data in the United States National Museum.

\section{OPISODASYS JORDAN}

Opisodasys Jordan, 1933, Nov. Zool., 39:72.

Genotype: Ceratophyllus vesperalis Jordan

Eye well developed. Labial palpus extending slightly beyond the apex of the fore coxa. Frontal tubercle small, acuminate. Pronotal ctenidium consisting of ten to twelve spines on a side. 
Fifth tarsal segment of each leg armed with four pairs of lateral plantar bristles, a basal and an apical submedian pair. Movable finger of the male with two or three heavily pigmented spiniforms.

This genus is represented in the East by a single species which seems to parasitize the flying squirrel in particular.

\section{Opisodasys pseudarctomys (Baker)}

(Plate XIV, figs. 68, 69, 72)

1904 Ceratophyllus pseudarctomys Baker, Proc. United States Nat. Mus., 27:399, Pl. XXIV, figs. 1-7.

1905 Ceratophyllus pseudarctomys Baker, Proc. United States Nat. Mus., 29: 133.

1905 Ceratophyllus acasti Rothschild, Nov. Zool., 12:168, P1. 7, figs. 19, 20.

1928 Ceratophyllus pseudarctomys Stewart, Cornell Univ. Agric. Exp. Sta., Mem. 101, p. 869.

1929 Ceratophyllus pseudarctomys Jordan, Nov Zool., 35:28, 176.

1933 Ceratophyllus peeudarctomys Stewart, Jour. New York Ent. Soc., 41:256.

1933 Opisodasys pseudarctomys Jordan, Nov. Zool., 39:72.

MaLe. Preantennal region of the head armed with an ocular row of three long bristles; above this row near the antennal groove are two or three weak bristles. Anterior and posterior margins of the antennal groove armed with numerous small setae. Posterior margin of the head with a row of about six stout bristles; above the most ventral bristle of this row is a single small bristle (Plate XIV, fig. 68). Pronotum with a single row of bristles and a ctenidium of about twelve spines on a side. Meso- and metanotum each armed with three rows of bristles anterior to which there may be a number of irregularly scattered ones. Each abdominal tergite armed with two rows of bristles. Anterior abdominal tergites further armed with two or three stout teeth on a side. Three antepygidial bristles present on a side, the outer two well developed, the middle aborted. Modified SEGMENTs: Movable finger long and curiously formed, the upper and lower angles produced posteriorly; the upper angle with a long curved spiniform, the lower angle with two much smaller ones. Acetabular bristles situated on an elongate process. Process of the clasper long and finger-like. Manubrium long and broad, reaching almost to the termination of the penis, and ending bluntly. Penis broad, tapering to a point; spring unusually short, not completing a turn. For further details concerning the structure of the male genitalia, see Plate XIV, fig. 72 . 
Female. In the specimen regarded as the female type there is an ocular row of three bristles, but the series of weak bristles along the anterior margin of the antennal groove is lacking. Three well-developed antepygidial bristles present on a side, the middle one the longest. Sternite VII bisinuate, the upper sinus very broad and shallow (Plate XIV, fig. 69).

Record. MAINE-Windy Pitch, Mount Katahdin, August 23. 1928, on Glaucomys sabrinus macrotis (Mearns), male and female (Harper and Hamilton).

EAstern Hosts. Flying Squirrel (Glaucomys sabrinus macrotis (Mearns) and G. volans volans (Linnaeus)), Woodchuck ("Arctomys monax").

Eastern localities. New York, Maine, (British Columbia).

TyPe Material. Male and female from Newport, Herkimer County, New York, on "Arctomys monax," in the United States National Museum.

\section{ORCHOPEAS JORDAN}

Orchopeas Jordan, 1933, Nov. Zool., 39:71.

\section{Genotype: Pulex wickhami Baker}

General structure essentially as in Ceratophyllus except that the pronotal ctenidium consists of nine or ten spines on a side and the fifth tarsal segment of each leg is armed with four pairs of lateral plantar bristles and a basal and an apical submedian pair. Movable finger of the male ham-shaped, much narrower basally than distally where it is armed with a row of four to seven heavily pigmented spiniforms. Head of the receptaculum seminis of the female more or less barrel-shaped. Males with two stout antepygidial bristles and one minute bristle on a side: females with three stout antepygidial bristles, the middle the longest, on a side.

This genus is represented in the East by four species which parasitize the common small mammals. They may be separated by the illustrations in Plates XV and XVI and by the following key:

\section{Key to the Eastern Species of Orchopeas}

1. Preantennal region with two distinct rows of bristles $\ldots \ldots \ldots \ldots \ldots .2$

Preartennal region with but one distinct row of bristles $\ldots \ldots \ldots \ldots .3$

2. Postantennal region with three bristles in addition to those of the

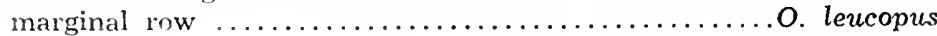

Postantennal region with but two bristles in addition to those of the marginal row $\ldots \ldots \ldots \ldots \ldots \ldots \ldots \ldots \ldots \ldots \ldots \ldots \ldots \ldots \ldots \ldots$ sexdentatus 
3. Labial palpus barely reaching to the apex of the fore coxa; process of the clasper nairow distally ................... wickhami

Labial palpus reaching to the middle of the fore trochanter; process of the clasper very broad distally ................. coedens

\section{Orchopeas wickhami Baker}

(Plate XV, figs. 75, 76, 77)

1395 Pulex wickhami and P. gillettei Baker, Can. Ent., 27:109.

1895 Pulex howardii Baker, Can. Ent., 27:110.

1896 Pulex wickhami, P. gillettei, and P. howardii Osborn, United States Dept. Agric. Div. Ent., Bull. V (n.s.), p. 149, fig. 81.

1898 Pulex gillettei and P. howardii Baker, Jour. New York Ent. Soc., 6: 54.

1904 Ceratophyllus wickhami Baker, Proc. United States Nat. Mus., 27:403, Pl. XXVI, figs. 1-7.

1905 Ceratophyllus wickhami Baker, Proc. United States Nat. Mus., 29:133.

1914 Ceratophyllus wickhami C. Fox, United States Public Health Ser., Bull. 97, Pl. XI, fig. 13; Pl. XVIII, fig. 44.

1928 Ceratophyllus wickhami Stewart, Cornell Univ. Agric. Exp. Sta., Mem. 101, p. 869.

1928 Ceratophyllus wickhami Jordan, Nov. Zool., 34:183.

1929 Ceratophyllus wickhami Jordan, Nov. Zool., 35:176.

1933 Ceratophyllus wickhami wickhami Stewart, Jour. New York Ent. Soc., 41: 257.

1933 Orchopeas wickhami Jordan, Nov. Zool., 39:71.

1934 Orchopeas wickhami Shaftesbury, Jour. Elisha Mitchell Sci. Soc., 49: 255.

1937 Orchopeas wickhami Jordan, Nov. Zool., 40:284.

MaLe. Preantennal bristles of the head arranged in one distinct row, the ocular row, consisting of three robust bristles. Above these in an oblique line are three or four much shorter ones. Labial palpus reaching to the apex of the fore coxa. A series of small setae along the posterior margin of the antennal groove. Postantennal region armed with a stout bristle and two or three small ones in addition to the marginal row of about six bristles (Plate XV, fig. 77). Pronotum armed with a single row of alternating weak and strong bristles. Meso- and metanotum each armed with two rows of bristles. Each abdominal tergite similarly armed. Metanotum and anterior four abdominal tergites with one or two stout dorsal teeth on a side. Modified SEGMENTS: Process of the clasper more or less triangular but sclerotized in such a way as to give the appearance of being very slender in the middle region and widened distally. Movable finger heavy, the posterior margin with four stout spiniforms, one long bristle, and one or two shorter ones (Plate $\mathrm{XV}$, fig. 75). Manubrium scimitar-like, ending in a curved point. Penis slender, ending in a curved point; spring short. 
not completing a single turn. Posterior arm of sternite IX expanded distally, its posterior margin armed with a stout spiniform located above a very short bristle.

Female. Preantennal region with only one or two bristles in addition to those of the ocular row. Otherwise, chaetotaxy of the head and general structure essentially as in the male. Sternite VII divided by two sinuses into three lobes, of which the most dorsal is least distinct; the second is more or less triangular and acuminate, between it and the third lobe the sinus is very deep. Head of the receptaculum seminis about twice as long as wide, longer than the tail. For further details concerning the structure of the female genitalia, see Plate XV, fig. 76 .

RECORDS. DISTRICT OF COLUMBIA-Washington, December 31. 1937, on "Sciurus carolinensis," female (J. Silver). FLORIDA-Tallahassee, July 12, 1937, on "Rattus alexandrinus," male; on "Rattus rattus," female, three males; January 17, 1937, on "Peromyscus gossypinus," male and female; January 20, 1937, on "Mus musculus," male, two females. GEORGIA-Beachton, December 30, 1925, in "stomach of Didelphis virginiana." male, three females (C. C. Sperry); Charleston County, March 20, 1936, on Lynx rufus floridanus (Rafinesque), female; Folkstown, January 18, 1936, on Sciurus corolinensis carolinensis Gmelin, three females; Camden County, February 29, 1936, on "Sciurus niger," male, two females (F. Harper); Grady County, December 6, 1935, on "gray squirrel," male and female (E. V. Komarek); Moorestown, on Sciurus carolinensis carolinensis Gmelin, four females (R. J. Sim) ; Tallula Falls, on "squirrel," female; Thomasville, November 13 and December 13, 1937, on Sciurus carolinensis carolinensis Gmelin, numerous specimens (E. V. Komarek); Nashville, April 23, September 18, March 13, and June 18, 1936, on "fox squirrel," numerous specimens; Taylor County, May, 1936, on same host, two males (H. Hixson). ILLINOISUrbana, January 26, 1933, on "gray squirrel," numerous specimens (M. D. Farrar); same locality and host, February 16, 1932, numerous specimens (C. O. Mohr); Metropolis, June 10, 1932, on same host, three males, three females (B. Harper); Olive Branch, December 5, 1934, on "fox squirrel," numerous specimens (H. H. Ross). IOWA-Ames, January, 1937, on "Sciurus niger," two males (G. Hendrickson); Luxemburg, November 23, 1937, on Glaucomys volans volans (Linnaeus), male and female; Eldon, November 12, 1937, on Sciurus carolinensis leucotis (Gapper), female (T. Scott). MARYLAND- 
Bell, July 7, 1928, in "bird's nest." female; Plummer Island, April 25, 1915, on "man," female (R. C. Shannon); same locality, May 19, 1913, on "woodchuck," three males (H. S. Barber); Takoma Park, July 15, 1930, on "flying squirrel," female (H. E. Ewing); Bladensburg, March 31, 1901, in "nest of white-footed mouse," female; Laurel, February 21, 1930, on "weasel," two males, two females (E. B. Marshall). MASSACHUSETTS - Amherst, June 7, 1907, on "Sciurus carolinensis," male (E. A. Chapin); Muskegett, June 18, 1926, on Peromyscus leucopus noveboracensis (Fischer), male and female (F. Harper); Wenham, October 12, 1923, on "red squirrel," two females. MINNESOTA-Rapidan, March, 1935, no host given, two females (W. P. Moore). NEW YORK-Adirondack Lodge, Essex County, July 31, 1925, on Peromyscus maniculatus gracilis (LeConte), female; Avalanche Lake, Essex County, July 30, 1926, on "Peromyscus maniculatus," female, two males; Cornwall, July 9, 1925, on Peromyscus leucopus noveboracensis (Fischer), male (F. Harper); Ithaca, on "red squirrel," female (MacGillivary). NORTH CAROLINA Pisgah National forest, March 2, 1936, on "raccoon," female (J. H. Stone); Asheville, July 18, 1935, on "opossum," male (F. J. Ruff). SOUTH CAROLINA-Clemson College, November 1, 1929, on "squirrel," female (R. B. Casey). VIRGINIAEast Falls Church. May 11, 1930, from "nest," male and female; January 30, 1918, on "Sciurus hudsonicus," male and female; February 27, 1934, on Glaucomys volans volans (Linnaeus), numerous specimens (E. A. Chapin); Difficult Run, September 14,1913 , in "nest of flying squirrel," male, four females (R. C. Shannon).

EAstern hosts. Gray Squirrel (Sciurus carolinensis carolinensis Gmelin, etc.), Flying Squirrel (Glaucomys volans volans (Linnaeus)), Red Squirrel (Sciurus hudsonicus loquax Bangs), Fox Squirrel ("Sciurus niger"), Chipmunk ("Tamias striatus"), Mink ("Mustela vison subsp."), Woodchuck ("Marmota monax subsp."), Weasel (Mustela noveboracensis noveboracensis (Emmons)), "Opossum," Bobcat (Lynx rufus floridanus (Rafinesque)), White-footed Mouse (Peromyscus leucopus noveboracensis (Fischer), etc.), Roof-rat ("Rattus alexandrinus"), Black Rat ("Rattus rattus"), House-mouse ("Mus musculus"), Short-tailed Shrew ("Blarina brevicauda subsp."), Star-nosed Mole (Condylura cristata (Linnaeus)), Cottontail Rabbit ("Sylvilagus sp."), "Man," Raccoon ("Procyon lotor"), Screech Owl ("Megascops asio"), "Dog." 
Eastern localities. District of Columbia, Florida, Georgia, Illinois, Iowa, Maryland, Massachusetts, Michigan, Minnesota, Nebraska, New Hampshire, New York, North Carolina, South Carolina, Virginia.

Type material. Female from Iowa City, Iowa, on "Sciuropterus volans"; two females (types of the synonym, Pulex gillettei) from Portland. Michigan, on "Sciurus canadensis." and two males and two females (types of the synonym, Pulex howardii) from Tallula Falls, Georgia, on "squirrel," in the United States National Museum.

This species is among our most abundant eastern fleas. Its favorite hosts seem to be the various squirrels.

\section{Orchopeas caedens (Jordan) \\ (Plate XVI, figs. 80, 81, 82)}

1925 Ceratophyllus caedens Jordan, Nov. Zool., 32:104, fig. 16.

1929 Ceratophyllus caedens durus Jordan, Nov. Zool., 35:29, fig. 3.

1930 Ceratophyllus caedens durus Jordan. Trans. IV Intern. Cong. Entomology (1928), 2:495, fig. 3.

1932 Ceratophyllus caedens durus Jordan, Nov. Zool., 38: 253.

1933 Ceratophyllus caedens caedens Stewart, Jour. New York Ent. Soc., 41: 257.

1933 Orchopeas caedens Jordan, Nov. Zool., 39:71.

1937 Orchopeas caedens durus Jordan, Nov. Zool., 40:284.

Male. Chaetotaxy of the head essentially as in O. wickhami. Preantennal region of the head armed with only one distinct row of three stout bristles; two or three much weaker ones located above this row. A number of small setae along the anterior and posterior margins of the antennal groove. Posterior margin of the head with a row of four or five bristles, anterior to which are three or four bristles near the antennal groove (Plate XVI, fig. 80). Labial palpus extending beyond the apex of the fore coxa. Modified Segments: Process of the clasper broad and truncate. Movable finger similar in shape to that of $O$. sexdentatus, armed on the posterior margin usually with four stout spiniforms. Posterior arm of sternite IX expanded distad into a sharply pointed lobe which bears a stout spiniform below which is a long bristle. For further details concerning the structure of the male genitalia, see Plate XVI, fig. 82.

Female. Chaetotaxy of the head essentially as in the male except that the bristles above the ocular row may be reduced in size and number. Receptaculum seminis essentially as in other species of the genus. Sternite VII variable in shape, 
usually with a deep sinus dividing the posterior margin into two lobes (Plate XVI, fig. 81), but sometimes with the sinus exceedingly shallow or absent.

RECORDS. MINNESOTA-No specific locality, September 13 , 1933, on Glaucomys sabrinus canescens Howell, male. NEW YORK-Long Lake, July, 1926, on "Sciurus hudsonicus," two males, two females (R. T. Hall); Adirondack Lodge, Essex County, August 12, 1925, on same host, male and female ( $F$. Harper); Vulcan Island, Lake Champlain, September 10, 1936, on same host, male and female.

EASTERN HoSts. Flying Squirrel (Glaucomys sabrinus canescens Howell), Red Squirrel (Sciurus hudsonicus loquax Bangs, etc.), Gray Squirrel (Sciurus carolinensis leucotis (Gapper)).

EAStern localities. Massachusetts, Minnesota, New York, (Canada).

Type MAterial. A series from Banff, Alberta, on Mustela americana in the N. C. Rothschild Collection (British Museum). Male and female from this lot in the United States National Museum.

Orchopeas sexdentatus pennsylvanicus (Jordan)

(Plate XVI, figs. 79, 83, 84)

1928 Ceratophyllus sexdentatus pennsylvanicus Jordan, Nov. Zool., 34: 184, figs. 8,9 .

1929 Ceratophyllus sexdentatus pennsylvanicus Jordan, Nov. Zool., 35:31. 1933 Orchopeas sexdentatus Jordan, Nov. Zool., 39: 72.

MaLE. Preantennal region of the head armed with two rows of bristles; the upper row with three in addition to those near the antenna, the lower row consisting of three much stouter ones. Postantennal region differing from the other eastern species of the genus in that there are but two bristles in addition to the marginal row of five or six (Plate XVI, fig. 79). Other general structural details essentially as in O. wickhami. ModIFIED SEGments: Process of the clasper prominent, thumblike, rounded at the apex. Posterior margin of the movable finger usually armed with five spiniforms, but sometimes with four or six. For further details concerning the structure of the male genitalia, see Plate XVI, fig. 84.

Female. Chaetotaxy of the head essentially as in the male except that the bristles of the upper preantennal row are more irregular and weaker. Receptaculum seminis as in O. wickhami. Sternite VII divided into two lobes by a deep sinus; the upper 
one long and clearly defined, truncate, the lower one rounded or acuminate distad. For further details concerning the structure of the female genitalia, see Plate XVI, fig. 83.

Records. ALABAMA-Sand Mountains, April 15, 1914, on "Neotoma floridana." male and female (A. H. Howell). GEORGIA-Okefinokee Swamp, November 13-15, 1935, on Neotoma floridana floridana (Ord), male and female (E. V. Komarek); Blood Mountain, January 3, 1934, two males, two females; Frogtown Gap, May 30, 1934, male and female (F. Harper); Neel Gap, May 31, 1933, on "wood rat," female (A. H. Howell). KENTUCKY-Mammoth Cave, August 6, 1929, on "Neotoma species," male (L. Giovannoli). MARYLANDPlummer Island, September 26, 1921, on Neotoma pennsylvanica Stone, male (A. Wetmore). NEW YORK-Schunemunk Mountain, Orange County, July 10, 1925, on Neotoma pennsylvanica Stone, male and female (F. Harper). PENNSYLVANIA-Reading, October 24, 1938, on same host, male and female; same locality and host, September 3, 1938, two females (E. L. Poole). VIRGINIA-Shore opposite Plummer Island, November 18, 1915, on "Neotoma species," male, three females (R. C. Shannon).

Eastern host. Wood-rat (Neotoma pennsylvanica Stone. etc.).

EASTERn Localities. Alabama, Georgia, Kentucky, Maryland, New York, Pennsylvania, Virginia.

Type material. Male and female from Boulder Creek, California, on "Neotoma species" in the United States National Museum.

Jordan (1928) has separated this species into a number of subspecies of which his $O$. sexdentatus pennsylvanicus is the only one that occurs in the East. This subspecies was based on numerous specimens from Neotoma pennsylvanica Stone at Rolling Rock Club, Ligonier, Pennsylvania, which are now in the N. C. Rothschild Collection (British Museum).

\section{Orchopeas leucopus (Baker)}

(Plate XV, figs. 74, 78)

1904 Ceratophyllus leucopus Baker, Proc. United States Nat. Mus., 27:387. 1905 Ceratophyllus leucopus Baker, Proc. United States Nat. Mus., 29:133. 1905 Ceratophyllus aeger Rothschild, Nov. Zool., 12:166, Pl. 6, figs. 5, 7, 9. 1914 Ceratophyllus leucopus C. Fox, United States Public Health Ser. Hyg. Lab., Bull. 97, Pl. XVIII, fig. 45.

1928 Ceratophyllus leucopus Stewart, Cornell Univ. Agric. Exp. Sta., Mem. 101, p. 869. 
1928 Ceratophyllus leucopus Jordan, Nov. Zool., 34:179.

1929 Ceratophyllus leucopus Jordan, Nov. Zool., 35:28, 170, 176.

1933 Ceratopinyllus leucopus Stewart, Jour. New. Yoik Ent. Soc., 41:257.

1933 Ceratophyllus leucopus Jordan, Nov. Zool., 39:62.

1933 Orchopeas leucopus Jordan, Nov. Zool., 39:72.

1934 Orchopeas leucopus Shaftesbury, Jour. Elisha Mitchell Sci. Soc., 49:255.

1937 Orchopeas leucopus Jordan, Nov. Zool., 40: 284.

MaLE. Bristles of the preantennal region of the head very similar in arrangement to those of $O$. sexdentatus. Postantennal bristles arranged as in $O$. wickhami. Labial palpus barely reaching to the apex of the fore coxa (Plate XV, fig. 74). Modified SEgments: The genitalia closely resemble those of $O$. wickhami, the main differences being in the shape of the movable finger. These differences may be readily appreciated by an examination of Plate XV, figs. 75 and 78 .

FEMale. Chaetotaxy of the head essentially as in the male; the bristles of the upper preantennal row may be reduced in number and size. The structure of sternite VII and of the receptaculum seminis as in $O$. wickhami.

RECORDS. DISTRICT OF COLUMBIA-Washington, March 16, 1932, on "Peromyscus leucopus," female (R. Greenfield). GEORGIA-Blood Mountain, June 3, 1934, on Peromyscus maniculatus nubiterre (Rhoads), male, three females; Tray Mountain, June 13, 1934, on Peromyscus leucopus leucopus (Rafinesque), female, two males; Okefinokee Swamp, January 28, 1936, on Peromyscus gossypinus gossypinus (LeConte), four males, four females (F. Harper). IOWA-Ames, March 3, 1938, on "white-footed mouse," male (I. Fox) ; same locality, 1935, on "Microtus pennsylvanicus," female (R. L. Roudabush); Dubuque, November 11, 1937, on Peromyscus leucopus noveboracensis (Fischer), female; Peru Bottoms, November 10,1938 , on same host, numerous specimens; Waukon, November 12, 1937, on Blarina brevicauda brevicauda (Say), two males, three females (T. Scott). MAINE-Mount Katahdin. August-September, 1928, on Peromyscus maniculatus abietorum (Bangs), numerous specimens (W. J. Hamilton, Jr.). MARYLAND-College Park, May, 1929, on "Peromyscus leucopus." numerous specimens (H. E. Ewing and H. S. Peters); February 17, 1932, same host and locality, three females (R. Greenfield) ; Riverdale, July 4, 1934, on "white-footed mouse," female (F. C. Bishopp); Burnt Mills, March 22, 1932, on "Peromyscus leucopus," two females; Chevy Chase, June, 1932, on same host, male and female (R. Greenfield); Dorchester 
County, May 13, 1933, on "wood mouse," female, three males (F. R. Smith); Dorsey, April 28, 1933, on "meadow mouse," female (G. R. Lunz); Plummer Island, 1904, on "Peromyscus leucopus," female. two males; Silver Spring, April 3, 1934, on "Microtus pennsylvanicus," male (H. E. Ewing). MASSACHUSETTS-Musekeget Island, July, 1924, on "Peromyscus leucopus," female (W. S. Brooks) ; Squibnocket, June 11, 1936, on Peromyscus leucopus fusus Bangs, male and female (C. N. Smith); Sturbridge, May 28, 1928, on Peromyscus leucopus noveboracensis (Fischer), female (F. Harper); W. Tisbury, June 9, 1936, on same host, male, three females (F. C. Bishopp). NEW HAMPSHIRE-Ossipec, July 17, 1927, on Peromyscus maniculatus gracilis (LeConte), female; Mount Washington, July 1, 1928, on same host, two females (F. Harper). NEW JERSEY-Beach Haven, September 10, 1934, on "Peromyscus leucopus," female (F. Harper); Moorestown, April 16, 1933, on "white-footed mouse," two females (G. R. Lunz). NORTH CAROLINA-Oconalufty R., on Peromyscus leucopus leucopus (Rafinesque), two females (R. L. Boke). OHIO-Fairfield County, April 23, 1935, on "white-footed mouse," male (R. Goslin). TENNESSEE-Greenbriar, April 18, 1931, on Peromyscus leucopus leucopus (Rafinesque), male; LeConte, April 12, 1931, on "Microtus montanus," female (R. L. Boke). VERMONT - Morgan, September 4, 1932, on Peromyscus maniculatus gracilis (LeConte), two males, two females (F. Harper); Pittsford Mills, August 13, 1927, on same host, female; East Barnet, August 21, 1927, on same host, female (G. M. Allen); Jay Peak. August 14, 1927, on same host, female (F. Harper). VIRGINIA-Dismal Swamp, April 5, 1931, on "whitefooted mouse," male (H. S. Peters) ; East Falls Church, October 21, 1928, on Peromyscus leucopus noveboracensis (Fischer), male, two females. WISCONSIN-Fish Creek, September 14, 1930, on Peromyscus leucopus novaboracensis (Fischer), male and female (F. J. W. Schmidt).

EASTERN HoSts. White-footed Mouse (Peromyscus leucopus leucopus (Rafinesque), etc.), Meadow-mouse ("Microtus pennsylvanicus"), House-mouse ("Mus musculus"), Shorttailed Shrew (Blarina brevicauda brevicauda (Say)).

EASTERn localities. District of Columbia, Georgia, Iowa, Maine, Maryland, Massachusetts, New Hampshire, New Jersey, North Carolina, Ohio, Rhode Island, Tennessee, Vermont, Virginia, Wisconsin, (Canada).

Type material. Female holotype from Peterboro, New York, 
on "Peromyscus leucopus," in the United States National Museum.

\section{MEGABOTHRIS JORDAN}

Megabothris Jordan, 1933, Nov. Zool., 39: 77.

\section{Genotype: Ceratophyllus walkeri Rothschild}

General structure very similar to that of Ceratophyllus. Pronotal ctenidium with about ten spines on a side. Fifth tarsal segment of each leg with the basal pair of plantar bristles noticeably displaced toward the median line, the other four pairs of lateral plantar bristles unchanged. Movable finger of the male with several heavily pigmented spiniforms on the posterior margin.

This genus is represented in the East by five species which occur on various rodents. They may be separated by the illustrations on Plates XVII, XVIII, and XIX, and by the following key:

\section{Key to the Eastern Species of Megabothris}

1. Postantennal region of the head with but three bristles in addition to

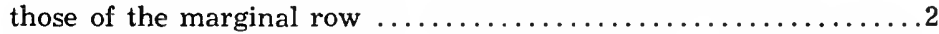

Postantennal region of the head with five bristles in addition to those

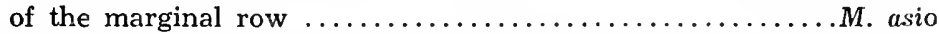

2. Movable finger of the male with two spiniforms apically ....M. acerbus

Movable finger with one spiniform apically, or with none $\ldots \ldots \ldots \ldots 3$

3. Movable finger without spiniforms distally; receptaculum seminis vermiform ......................................

Movable finger with a spiniform or heavily pigmented bristle distally; receptaculum seminis not vermiform ...................

4. Posterior margin of the movable finger expanded apically into a process which bears a heavily pigmented bristle or spiniform; head of the receptaculum seminis rounded apically .............. quirini

Posterior margin of the movable finger not as above; head of the receptaculum seminis narrowed apically and at the base ...M. vison

Megabothris asio (Baker)

(Plate XVII, figs. 85, 86, 88, 89)

1904 Ceratophyllus asio Baker, Proc. United States Nat. Mus., 27:338.

1905 Ceratophyllus asio Baker, Proc. United States Nat. Mus., 29:132.

1929 Ceratophyllus asio Jordan, Nov. Zool., 35:33, Pl. I, figs. 10, 11; p. 176.

1930 Ceratophyllus asio Jordan, Trans. IV Intern. Cong. Ent. (1928), 2:495, fig. 2.

1933 Ceratophyllus asio Stewart, Jour. New York Ent. Soc., 41:255.

1933 Ceratophyllus asio Jordan, Nov. Zool., 39:62.

1933 Megabothris asio Jordan, Nov. Zool., 39: 77.

1939 Megabothris asio I. Fox, Proc. Ent. Soc. Washington, 41: 47, Pl. 6, fig. 3. 
Male. Preantennal region of the head armed with two rows of bristles; the upper row consisting of about six bristles, the lower row consisting of three long and stout ones. Genal process acutely pointed posteriorly. First antennal joint with about ten small setae; second antennal joint with about five bristles. some of which may exceed the third joint in length. A series of about a dozen irregularly arranged bristles along the posterior margin of the antennal groove. Postantennal region armed with a marginal row of about six bristles; anterior to this is another row of about six bristles which are sometimes irregularly arranged; above this row there is usually a single bristle close to the antennal groove. Pronotum armed with two rows of bristles. Meso- and metanotum each armed with three or four rows of bristles, the bristles of the posterior row being long and robust. the other small and weak. Each abdominal tergite with two or three rows of bristles; the anterior tergites further armed with one to three stout dorsal teeth on a side. Modified SEgments: Process of the clasper much longer than in other species of the genus, tapering gradually to a blunt termination where it is armed with two small bristles. Movable finger with two short spiniforms at the apex and a longer, more robust one at the outer angle. Manubrium short and broad, not ending in a point. Penis long and slender, ending in a curved process; spring not long, completing one or two large circles about the distal third of the penis. Sternite VIII expanded apically and armed with a number of slender curved setae and two large bristles. For further details concerning the structure of the male genitalia. see Plate XVII, fig. 85.

Female. Chaetotaxy of the head essentially as in the male (Plate XVII, figs. 88, 89). Sternite VII divided by a broad sinus into two lobes, of which the upper is rounded and extends further distad than the pointed lower lobe. Head of receptaculum seminis oval, less than twice as long as wide. For further details concerning the structure of the female genitalia, see Plate XVII, fig. 86.

RECORDS. MASSACHUSETTS-Edgartown, October 2, 1937, on Microtus pennsylvanicus pennsylvanicus (Ord), two males: Chilmark, on same host, September 2, 1937, male and female (C. N. Smith).

EASTERN HOSTs. Meadow-mouse (Microtus pennsylvanicus pennsylvanicus (Ord), Screech Owl ("Megascops asio").

Eastern localities. Iowa, Massachusetts, New York.

Type material. Female holotype from Wellesley, Massachu- 
setts, on "Megascops asio" in the United States National Museum.

\author{
Megabothris acerbus (Jordan) \\ (Plate XVIII, figs. 91, 92, 93)
}

1925 Ceratophyllus acerbus Jordan, Nov. Zool., 32:111, fig. 43.

1929 Ceratophyllus acerbus Jordan, Nov. Zool., 35:170. fig. 5.

1933 Ceratophyllus acerbus Stewart, Jour. New York Ent. Soc., 41:255.

1933 Megabothris acerbus Jordan, Nov. Zool., 39:77.

1927 Megabothris acerbus Jordan, Nov. Zool., 40:284.

MaLE. Preantennal region of the head armed with two rows of bristles; the upper row consisting of about five, the lower row consisting of three much longer and more robust ones. Posterior margin of the antennal groove with about a dozen weak bristles. Postantennal region with a marginal row of about five bristles, anterior to which are three bristles of which one is much stouter than the others. Pronotum armed with a single row of alternating strong and weak bristles. Mesonotum armed with a marginal row of long bristles, anterior to which are three rows of much weaker ones. Metanotum and each abdominal tergite with a marginal row of long bristles, anterior to which are one or two rows of weaker ones. Metanotum and first four abdominal tergites further armed with one or two teeth on a side. Modified Segments: Process of the clasper broad and short, truncate, its apex with three weak bristles. Movable finger about three times as long as broad with the anterior margin produced into an angle at about the middle. Apex rounded, with four or five weak bristles and two small heavily pigmented spiniforms. Posterior margin armed with a long bristle. Penis bladelike, acutely pointed; spring long, but not completing a turn in the single specimen available. For further details concerning the structure of the male genitalia, see Plate XVIII, fig. 92.

FEMALE. Chaetotaxy of the head essentially as in the male except that the bristles of the upper preantennal row may be reduced in number (Plate XVIII, fig. 91). Sternite VII divided by a deep sinus into two more or less triangular lobes. Receptaculum seminis as in other members of the genus. For further details concerning the structure of the female genitalia, see Plate XVIII, fig. 93.

EASTERN HOST. Chipmunk (Tamias striatus lysteri (Richardson)).

Eastern Localities. Massachusetts, Michigan, New York, (Canada). 
Type material. Female holotype from Canada, on "Tamias striatus" in the N. C. Rothschild Collection (British Museum).

\author{
Megabothris quirini (Rothschild) \\ (Plate XVII, fig. 87; Plate XVIII, figs. 90, 94)
}

1905 Ceratophyllus quirini Rothschild, Nov. Zool., 12:163, PI. VI, fig. 1.

1905 Ceratophyllus quirini Baker, Proc. United States Nat. Mus., 29:133. 1929 Ceratophyllus quirini Jordan, Nov. Zool., 35:174.

1933 Ceratophyllus quirini Stewart, Jour. New York Ent. Soc., 41:256.

1933 Megabothris quirini Jordan, Nov. Zool., 39:77.

1937 Megabothris quirini Jordan, Nov. Zool., 40:284.

Male. Preantennal region of the head armed with tivo rows of bristles; the upper row consisting of about seven bristles, the lower row of three much longer ones. Posterior margin of the antennal groove with a series of small setae. Postantennal region armed with three bristles in addition to those of the marginal row (Plate XVIII, fig. 90). Other details of general structure essentially as in $M$. asio. Modrfied Segments: Process of the clasper long and finger-like, its apex rounded. Movable finger large, concave between the outer angle and the apex, and bearing on the angle a long heavy spiniform in front of which is another much shorter one. Another distinct heavily pigmented bristle at the apex. For further details concerning the structure of the male genitalia, see Plate XVII, fig. 87 .

Female. General structure and chaetotaxy essentially as in the male. Sternite VII in the single specimen available without a deep sinus, receptaculum seminis essentially as in other species of the genus. For further details regarding the structure of the female genitalia, see Plate XVIII, fig. 94, which is drawn from a single specimen taken at Atlin, British Columbia, on "Microtus pennsylvanicus drummondi" loaned through the courtesy of Dr. Karl Jordan.

Record. MAINE-Windy Pitch, Mount Katahdin, August 23, 1928, on Glaucomys sabrinus macrotis (Mearns), male (W. J. Hamilton, Jr.).

EASTERn Hosts. Jumping Mouse (Zapus hudsonius campestris Preble, and "Zapus insignis"), Flying Squirrel (Glaucomys sabrinus macrotis (Mearns)) .

Eastern Localities. Maine, Minnesota, New York, (Canada).

Type material. Five males from Red Deer, Alberta, on "Evotomys gapperi" and "Evotomys satturatus" in the N. C. Rothschild Collection (British Museum). 


\section{Megabothris wagneri (Baker) \\ (Plate XIX, figs. 96, 97)}

1904 Ceratophyllus wagneri Baker, Proc. United States Nat. Mus., 27:387, Pl. XV, figs. 3-7.

1905 Ceratophyllus wagneri Baker, Proc. United States Nat. Mus., 29:133. 1914 Ceratophyllus wagneri C. Fox, United States Public Health Ser. Hyg. Lab., Bull. 97, P1. X, fig. 11; Pl. XIX, fig. 48.

1923 Ceratophyllus wagneri Dunn and Parker, United States Public Health Ser., Rep. 38: 2774.

1928 Ceratophyllus peromysci Stewart, Can. Ent., 60:148, figs. 1, 2.

1929 Ceratophyllus wagneri Jordan, Nov. Zool., 35: 35.

1930 Ceratophyllus wagneri Jordan, Trans. IV Intern. Cong. Ent. (1928), p. 498, figs. 7-9.

1930 Ceratophyllus wagneri Stewart, Can. Ent., 62: 152.

1933 Monopsyllus wagneri Jordan, Nov. Zool., 39: 78.

MaLe. Preantennal region of the head armed with two rows of bristles, the upper row consisting of five or six bristles, the lower row of three much stouter and longer ones. Labial palpus reaching to the apex of the fore coxa. Posterior margin of the antennal groove with a series of small setae. Postantennal region of the head armed with a marginal row of about five bristles anterior to which are three more bristles near the second antennal segment. Pronotum with a single row of alternating bristles and small setae. Meso- and metanotum each with two rows of bristles anterior to which are several others either forming another row or irregularly arranged. Each abdominal tergite with two rows of bristles. Metanotum and anterior abdominal tergites with one to three stout dorsal teeth on a side. Modified segments: Process of the clasper broad and long, almost as long as the movable finger, armed apically with one or two slender bristles. Movable finger broad and heavy, armed on the posterior margin with three stout heavily pigmented spiniforms of which the lowest is the longest, being about four times as long as the others. Manubrium short and broad, ending bluntly. Penis long and slender, ending distally in a long curved process; spring long, completing one or two turns. For further details concerning the structure of the male genitalia, see Plate XIX, fig. 97.

Female. General structure and chaetotaxy essentially as in the male. Receptaculum seminis vermiform, the head slightly more expanded than the tail. For further details, see Plate XIX, fig. 96, which was drawn from a specimen on "Mus species" at Kelowna, British Columbia (A. Gate), loaned through the courtesy of Dr. Karl Jordan. 
Record. IOWA-Dubuque, November 6, 1937, on Glaucomys volans volans (Linnaeus), male ( $\mathrm{T}$. Scott) .

EASTERN host. Flying Squirrel (Glaucomys volans volans (Linnaeus) ). (Known also from various rodents in the West.)

Eastern Localities. Iowa, (Western United States and Canada).

Type material. Male cotype from Moscow, Idaho, on "Peromyscus leucopus" in the United States National Museum.

This species has hitherto been found only in the western half of the country, where it is thought to break into several subspecies. These subspecies have been established by Jordan (1929) almost entirely on the basis of the female genitalia, hence it is not possible to place subspecifically the Iowa male. It is believed, however, that this specimen is referable to $M$. wagneri wagneri (Baker).

\section{Megabothris vison (Baker) \\ (Plate XIX, figs. 95, 98, 99)}

1904 Ceratophyllus vison Baker, Proc. United States Nat. Mus., 27:388.

1904 Ceratophyllus lucidus Baker, Proc. United States Nat. Mus., 27:388, Pl. XX, figs. 5-9.

1905 Ceratophyllus lucidus Baker, Proc. United States Nat. Mus., 29:132.

1905 Ceratophyllus vison Baker, Proc. United States Nat. Mus., 29:133.

1928 Ceratophyllus vison Stewart, Cornell Univ. Agric. Exp. Sta., Mem. 101, p. 869.

1929 Ceratophyllus vison Jordan, Nov. Zool., 35:35, 170.

1933 Ceratophyllus vison Stewart, Jour. New York Ent. Soc., 41:256.

1933 Monopsyllus vison Jordan, Nov. Zool., 39: 78.

MaLe. Frontal notch distinct, much lower on the head than in M. wagneri. Labial palpus reaching beyond the middle of the fore trochanters. Chaetotaxy of the head (Plate XIX, fig. 95), and general structure essentially as in $M$. wagneri. Modified SEGMENTS: Process of the clasper rather slender and finger-like, much shorter than the movable finger. Movable finger large and broad, the posterior margin concave; armed apically with two slender bristles and one long stout spiniform, the lower angle armed with another long stout spiniform. Manubrium short, blunt terminally. Penis rather long, not ending in a curved process; spring not completing a single turn. For further details concerning the structure of the male genitalia, see Plate XIX, fig. 99.

Female. Chaetotaxy of the head essentially as in the male except that the bristles of the upper preantennal row may be reduced in size and number. Other general structural details 
as in the male. Sternite VII divided by a wide shallow sinus into two lobes of which the upper is more prominent than the lower. Head of the receptaculum seminis longer than the tail, about twice as long as wide. For further details concerning the structure of the female genitalia, see Plate XIX, fig. 98 .

RECoRDS. MASSACHUSETTS-Amherst, October 14, 1916, on "Sciurus hudsonicus," male. MINNESOTA-Itasca Park, May 6, 1933, on "red squirrel," female. NEW YORK-Clear Lake, Essex County, July 28, 1926, on Sciurus hudsonicus gymnicus Bangs, female (W. J. Shoonmaker); Heart Lake, July 22, 1922, on "Sciurus hudsonicus," male and female (F. Harper); Long Lake, July 23, 1926, on same host, male and female (R. T. Hatt).

EASTERn hosts. Weasel (Mustela noveboracensis noveboracensis (Emmons)), Mink ("Putorius vison"), Red Squirrel (Sciurus hudsonicus loquax Bangs, etc.), Chipmunk ("Tamias striatus").

Eastern localities. Maine, Massachusetts, Minnesota, New York.

Type material. Two males from Peterboro, New York, on "Putorius vison" in the United States National Museum.

\section{NOSOPSYLLUS JORDAN}

Nosopsyllus Jordan, 1933, Nov. Zool., 39: 76.

Genotype: Pulex fasciatus Bosc.

Eye well developed. Ocular bristle on a level with or slightly above the upper margin of the eye. Labial palpus extending to or slightly beyond the apex of the fore coxa. Frontal tubercle small and acuminate. Pronotal ctenidium consisting of nine or ten spines on a side. Fifth tarsal segment of each leg armed as in Ceratophyllus. MALES: Posterior process of sternite IX dilate, divided into two lobes by a sinus; movable finger without spiniforms. Females: Tail of the receptaculum seminis long and curved about the head.

This genus is represented in the East by a single species which is parasitic on the rat.

\section{Nosopsyllus fasciatus (Bosc) \\ (Plate XX)}

1801 Pulex fasciatus Bosc, Bull. de. Sci. p. Soc., Philo. No. 44, Vol. II, p. 156. 1895 Pulex fasciatus Baker, Can. Ent., 27:111.

1896 Pulex fasciatus Osborn, United States Dept. Agric. Div. Ent., Bull. V (n.s.), p. 148. 
1904 Ceratophyllus oculatus Baker, Proc. United States Nat. Mus., 27:387, Pl. XIX, figs. 10-14.

1904 Cerotophyllus canadensis Baker, Proc. United States Nat. Mus., 27: $388, \mathrm{Pl}$. XX, figs. $1-4$.

1905 Ceratophyllus oculatus and canadensis Baker, Proc. United States Nat. Mus., 29: 133.

1910 Ceratophyllus fasciatus C. Fox, United States Public Health and Mar. Hosp. Ser., Bull. 30, p. 136, Pl. II, figs. 1-4.

1914 Ceratophyllus fasciatus C. Fox, United States Public Health Ser. Hyg. Lab., Bull. 97, Pl. VI, fig. 1; Pl. XVII, fig. 30.

1921 Ceratophyllus fasciatus Jordan and Rothschild, Ectoparasites, 1:178, figs. $165,166$.

1925 Ceratophyllus fasciatus C. Fox, United States Public Health, Ser., Rep. 40:1917.

1928 Ceratophyllus fasciatus Stewart. Cornell Univ. Agric. Exp. Sta., Mem. 101, p. 869.

1928 Ceratophyllus fasciatus Jordan, Nov. Zool., 34:183.

1929 Ceratophyllus fasciatus Jordan, Nov. Zool., 35: 33.

1929 Ceratophyllus fasciatus Hasseltine, United States Public Health Ser., Rep. 44:583.

1931 Ceratophyllus fasciatus C. Fox, United States Public Health Ser., Rep. 46: 574 .

1933 Ceratophyllus fasciatus Stewart, Jour. New York Ent. Soc.. 41:255.

1933 Nosopsyllus fasciatus Jordan, Nov. Zool., 39:76.

1934 Nosopsyllus fasciatus Shaftesbury, Jour. Elisha Mitchell Sci. Soc., 49: 255.

1935 Ceratophyllus fasciatus Vogel and Cadwallader, United States Public Health Ser., Rep. 50:1953.

MALE. Bristles of the preantennal region variable in arrangement. There is always an ocular row of three bristles; above this there are usually four to six bristles near the antennal groove. Genal process acutely pointed posteriorly. A series of small setae along the posterior margin of the antennal groove. Postantennal region of the head armed with a long stout bristle near the second antennal joint; dorsal to this there may be another shorter bristle, and a marginal row of four to six bristles (Plate XX, fig. 101). Pronotum with a single row of bristles. Meso- and metanotum each armed with two or three rows of bristles. Each abdominal tergite armed with two rows of bristles. In addition, the anterior three or four abdominal tergites and the metanotum armed with one or two short stout teeth on a side. Three antepygidial bristles present on a side, the middle long, about three times as long as the upper bristle; the lower bristle reduced to a small seta. Modified SEgments: Process of the clasper broad, with a prominent posterior angle, bearing two or three weak bristles apically. Movable finger more or less evenly rounded posteriorly, the posterior margin 
with two stout bristles, between which is a much weaker bristie, and one or two others near the apex. Manubrium reaching to about two-thirds the length of the penis, terminating more or less bluntly. Penis bladelike, ending in a curved process; spring very long and completing several turns. For further details concerning the structure of the male genitalia, see Plate XX. figs. 100, 102.

Female. Chaetotaxy of the head differing somewhat from that of the male (Plate XX, fig. 103). Three antepygidial bristles present on a side, of which the uppermost is much shorter than the other two. Sternite VII without a sinus, its posterior margin irregularly rounded or slanting. Head of the receptaculum seminis globular; tail about one and one-half times as long as the head. For further details concerning the structure of the female genitalia, see Plate XX, fig. 104 .

RECORDS. FLORIDA-Jacksonville, January 25, 1934, on Rattus norvegicus (Erxleben), female. IOWA-Osceola, July 7, 1934, on same host, female (G. S. Cantonwine); Des Moines, June, 1937, male, seven females (R. L. Roudabush). ILLINOIS -Champaign, June 14, 1938, on "house-rat," male, three females (W. P. Mohr). MARYLAND-Baltimore, on Rattus norvegicus (Erxleben), six females; Dorchester County, June 5, 1933, on "rat," male, two females (F. R. Smith); Takoma Park. on same host. September 18, 1938, female (H. E. Ewing). MASSACHUSETTS - Vineyard Haven, June 11, 1936, on Rattus norvegicus (Erxleben), female (C. N. Smith); West Earnstable. May 10, 1913, host unknown, female (W. J. Jenkins) ; Edgartown, October 15, 1937, on "Norway rat," female: November-December. 1937, four females (C. N. Smith). OHIO -Lancaster, November 26, 1935, on "brown rat." female; May 30, 1935, on same host, female (R. Goslin). PENNSYLVANIA -Philadelphia, November 14, 1932, on "rat," male and female (C. Fox). RHODE ISLAND-Providence, November 27, 1912 , on "rats," male and female (S. H. Robinson).

EASTERN HoSTS. House-rat (Rattus norvegicus (Erxleben)): "Mink," Wood-rat ("Neotoma pennsylvania"), White-footed Mouse ("Peromyscus leucopus"), Weasel (Mustela noveboracensis noveboracensis (Emmons)).

Eastern localities. District of Columbia, Florida, Georgia, Iowa, Illinois, Kentucky, Louisiana, Maryland, Massacl,nsetts. New York, Ohio, Pennsylvania, Rhode Island, Wisconsin, Virginia. 
Type MAterial. On the garden dormouse ("Myoxus nitela Linn"). Type locality not indicated. Location of type material not ascertained. 


\section{FAMILY HYSTRICHOPSYLLIDAE TIRABOSCHI}

1904 Hystrichopsyllinae Tiraboschi, Archiv. de Parasit., 8:242.

1905 Hystrichopsyllidae Baker, Proc. United States Nat. Mus., 29:124.

1905 Ctenopsyllidae Baker, Proc. United States Nat. Mus., 29:124.

1909 Hystrichopsyllidae Oudemans, Nov. Zool., 16:155.

1915 Leptopsyllidae Rothschild, Ent. Mo. Mag., 51:80.

1915 Hystrichopsyllidae Rothschild, Ent. Mo. Mag., 51:83.

1926 Leptopsyllidae Dampf, Ent. Mitt., 15:384.

1926 Hystrichopsyllidae Dampf, Ent. Mitt., 15:385.

1929 Hystrichopsyllidae Ewing, Manual External Parasites, p. 172.

1936 Ctenopsylliảe Wagner, Tierwelt Mitteleuropas, Bd. 6, Abt. 17, s. 14.

The Hystrichopsyllidae and the Ischnopsyllidae differ from the other families of fleas occurring in our fauna by the presence of a dorsal sulcus separating the frons from the posterior region of the head and permitting motion between the two. Unfortunately, this character is not always distinct among the various genera, and some experience is required to recognize transitional forms. The following characteristics, which pertain to the eastern genera, are additional aids in distinguishing the hystrichopsyllids. In a few genera the females have a double receptaculum seminis, while in others this structure is single. The members of the latter group possess both a genal and a pronotal ctenidium (except in Catallagia). The eyes are weakly developed or absent. The maxillae are roughly triangular and taper to a sharp point. In most cases there are two or more rows of bristles on the abdominal tergites, and in most instances the abdominal tergites are further armed with short stout teeth. Three to five antepygidial bristles are present on a side, except in the case of Nearctopsylla which has one or two. The family is represented in the East by ten genera which may be separated by the following key:

Key to the Eastern Genera of Hystrichopsyllidae

1. First abdominal tergite with a ctenidium consisting of spines as long as those of the pronotum ................ Stenoponia, p. 81

First abdominal tergite without such a ctenidium $\ldots \ldots \ldots \ldots \ldots .2$ 


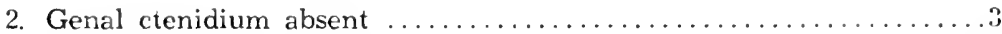

Genal ctenidium present ............................

3. Females with two receptacula seminis ..........Atyphloceras, p. 80

Females with one receptaculum seminis ...........Catallagia, p. 102

4. Genal ctenidium consisting of more than three spines $\ldots \ldots \ldots \ldots \ldots 5$

Genal ctenidium consisting of less than three spines $\ldots \ldots \ldots \ldots \ldots$

5. Genal ctenidium consisting of five or six spines $\ldots \ldots \ldots \ldots \ldots \ldots \ldots$

Genal ctenidium consisting of four spines $\ldots \ldots \ldots \ldots \ldots \ldots \ldots \ldots$

6. Spines of the genal ctenidium spatulate, arranged in a vertical line....

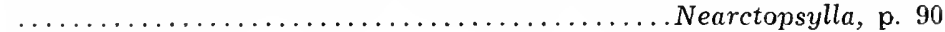

Spincs of the genal ctenidium long and slender, arranged in a hori-

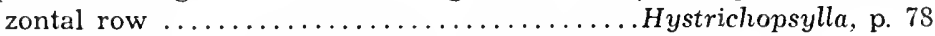

7. Frons with two or more spinforms near the frontal angle ............ .Ctenopsyllus, p. 88

Frons without such spiniforms . ............ Doratopsylla, p. 92

8. Genal ctenidium consisting of two spines, one overlappng the other ..9 The two spines of the genal ctenidium separated and not over-

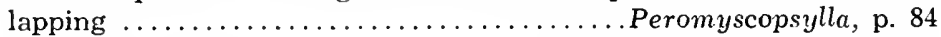

9. Fifth tarsal segment of the fore and middle legs with a basal submedian pair of bristles ...................Epitedia, p. 95

Fifth tarsal segment of the fore and middle legs without a basal submedian pair of bristles ...................Tamiophila, p. 100

\section{HYSTRICHOPSYLLA TASCHENBERG}

Hystrichopsylla Taschenberg, 1880, Die Flohe, p. 83.

\section{Genotype: Pulex talpae Curtis}

Eye vestigial. Labial palpus consisting of five segments. A genal and a pronotal ctenidium present. Abdomen with a row of lateral teeth on tergites II, III, and IV. Each abdominal tergite armed with three rows of bristles. Females with two receptacula seminis. Three antepygidial bristles present in the male, four in the female, on each side. Anterior tibia provided with a comb of robust heavily pigmented bristles on the posterior border. Fifth tarsal segment of each leg armed with five pairs of lateral plantar bristles, without a basal submedian pair. Size large, four or five millimeters in length.

This genus is represented in the East by a single rare species which is parasitic on wild mice.

\section{Hystrichopsylla gigas tahavuana (Jordan)}

(Plate XXI, figs. 106, 107, 108)

1929 Hystrichopsylla gigas tahavuana Jordan, Nov. Zool., 35:173, fig. 8.

1933 Hystrichopsylla gigas tahavuana Stewart, Jour. New York Ent. Soc., 41: 260 .

1933 Hystrichopsylla gigas tahavuana Jordan, Nov. Zool., 39:65: 
Female. In the single specimen at hand the preantennal region of the head is armed with a distinct row of about seven bristles, below which are two widely separated much stouter ones which may be part of another row. Frons and gena with numerous scattered small setae. Genal ctenidium consisting of five long slender spines. Posterior margin of the antennal groove with a number of small setae. Postantennal region apparently armed with two rows of bristles in addition to the marginal row. Genal process prominent and acuminate (Plate XXI, fig. 108). Pronotum armed with two rows of bristles and ctenidium of about fifteen spines on a side. Meso- and metanotum each armed with four or five rows of bristles. Each abdominal tergite armed with three rows of bristles. Second abdominal tergite with five to seven lateral teeth, third with four, and fourth with one or two on a side. Abdominal sternites armed with numerous bristles. Sternite VII without a deep sinus, the posterior margin uneven in outline. Head of the receptaculum seminis more or less quadrangular, much wider than the tail. For further details concerning the structure of the female genitalia, see Plate XXI, fig. 107.

The above description and the accompanying illustrations are based on a female taken from "Microtus pennsylvanicus" at Adirondack Lodge, Essex County, New York, loaned through the courtesy of Dr. Karl Jordan.

MaLE. In his description of the male of the eastern subspecies, Dr. Jordan (1929) states: "About the middle of clasper and oblique row of three long bristles, in front of them four to six much smaller ones and a few marginal hairs; near and at posterior margin from four to six bristles, of which the two upper ones are moderately large. Ventral arm of IX st. characteristic; with four each side and the apex enlarged upwards on (each side) into a compressed cone which leans slightly distad." His illustration is redrawn in Plate XXI, fig. 106.

EASTERN Hosts. Short-tailed Shrew ("Blarina brevicauda"), Meadow Mouse ("Microtus pennsylvanicus"), White-footed Mouse (Peromyscus leucopus noveboracensis (Fischer)).

EASTERN LOCALITY. New York.

Type Material. The eastern subspecies of this species described by Jordan as $H$. gigas tahavuana was based upon a male and female from "Blarina brevicauda" and female from "Microtus pennsylvanicus" at New York, which are in the N. C. Rothschild Collection (British Museum). 


\section{ATYPHLOCERAS JORDAN AND ROTHSCHILD}

Atyphloceras Jordan and Rothschild, 1915, Ectoparasites, 1:59.

\section{Genotype: Ceratophyllus multidentatus C. Fox}

Genal ctenidium absent; pronotal ctenidium present. Eye reduced. Labial palpus consisting of five to eight segments. Abdominal tergites I to VI with two to seven lateral teeth on a side. Three antepygidial bristles present on a side. Fifth tarsal segment of each leg armed with five pairs of lateral plantar bristles. Females with two receptacula seminis.

This genus is represented in the East by a single rare species which is found on small mammals.

\section{Atyphloceras bishopi Jordan}

$$
\text { (Plate XXI, figs. 105, 109) }
$$

1933 Atyphloceras bishopi Jordan, Nov. Zool., 39:63, figs. 11, 12.

The following description and the accompanying illustrations are taken from Jordan's original descriptions as no specimen has been available for study.

Male. Distinguished from A. multidentatus C. Fox (California) and A. echis J. and R. (Arizona) by the tubercle of the frons being more distant from the anterior oral angle, by the labial palpus consisting of five segments, instead of six or more, and by the posterior abdominal segments. Distance of the frontal tubercle from the anterior oral angle twice as long as in other known species of the genus. Postantennal region of the head with four rows of bristles, of which the second consists of only one or two bristles. Labial palpus reaching to the apex of the fore coxa. Each abdominal tergite armed with three rows of bristles; tergites I-VI further armed with apical teeth (on the two sides together) as follows: $8,12,9,7,6,2$. Modified SEGMENTS: Process of the clasper conical with five or six bristles at the apex and posterior margin and five or six small ones laterally and dorsally, on the inner side of the apex a stronger bristle. Movable finger long and broad. Posterior arm of sternite IX narrow, slightly widened at the apex, where it is armed with a number of bristles of various sizes. For further details concerning the structure of the male genitalia, see Plate XXI, fig. 105.

Female. Abdominal tergites I-VI armed with apical teeth (on both sides together) as follows: 8, 13, 8, 8, 5, 2. Other 
general structural details as in the male. Sternite VII divided by a rounded sinus into two lobes, of which the upper does not extend so far distad as the lower. Heads of the receptacula seminis equal in size, globular, not much shorter than the tails. For further details of the structure of the female genitalia, see Plate XXI, fig. 109.

EASTERN HOSTS. Short-tailed Shrew (Blarina brevicauda talpoides (Gapper)), Meadow Mouse (Microtus pennsylvanicus pennsylvanicus (Ord)).

EASTERN LOCALITY. New York.

Type material. Male holotype from Fairport, New York, on Blarina brevicauda talpoides (Gapper), and female allotype from Mendon Ponds, Monrce County, New York, on Microtus pennsylvanicus pennsylvanicus (Ord) in the N. C. Rothschild Collection (British Museum).

\section{STENOPCNIA JORDAN AND ROTHSCHILD}

Stenoponia Jordan and Rothschild, 1911, Proc. Zool. Soc. London, p. 391.

Genotype: Hystrichopsylla tripectinata Tiraboschi

Frontal tubercle absent. A genal, a pronotal, and an abdominal ctenidium present. Labial palpus short, not extending much beyond the apex of the maxilla. Eye vestigial or absent. Club of the antenna short. First abdominal tergite with a ctenidium whose spines are as long as those in the pronotal ctenidium; second to fifth abdominal tergites with rows of short, stout teeth. Four to six antepygidial bristles present on a side in the female; three or four in the male. Posterior border of the tibia with numerous heavily pigmented bristles. Fifth tarsal segment with four pairs of lateral plantar bristles and a basal median pair. Females normally with only one receptaculum seminis. Size large, four or five millimeters in length.

This genus is represented in the East by a single species which is found on various wild mice.

\section{Stenoponia americana (Baker) \\ (Plate XXV, figs. 128, 130, 132)}

1898 Hystrichopsylla americana Baker, Ent. News, 10:37.

1904 Hystrichopsylla americana Baker, Proc. United States Nat. Mus., 27: 432 .

1905 Hystrichopsylla americana Baker, Proc. United States Nat. Mus., 29:137.

1915 Stenoponia americana Rothschild, Ectoparasites, 1:30. 
1919 Stenoponia wetmorei Chapin, Bull. Brooklyn Ent. Soc., 14:52.

1929 Stenoponia americana Jordan, Nov. Zool., 35: 176.

1937 Stenoponia americana Jordan, Nov. Zool., 40: 285.

Female. Preantennal region of the head with six bristles, of which three are arranged in an oblique line near the antennal groove, while three are located on the lower gena. Numerous small setae scattered over the frons. Genal ctenidium consisting of about thirteen spines on a side. Genal process wide, rounded distally. Second antennal segment armed with about six bristles, one or two of which are longer than the third antennal segment. Postantennal region of the head armed with about six bristles and a number of small setae (Plate XXV, fig. 132). Pronotum with a ctenidium of twenty-five or twenty-six spines on a side. Anterior to the ctenidium are about four rows of bristles. Meso- and metanotum each with four or five rows of bristles. Each abdominal tergite armed with about three rows of bristles. First abdominal tergite with a ctenidium of about twenty-one spines on a side. Abdominal tergites II to IV each with a series of short stout teeth. The number of teeth in each series is variable; usually tergite $V$ bears the fewest teeth. Five antepygidial bristles present on a side. Bristles on the posterior margin of the tibia very long and heavily pigmented. Seventh sternite divided by a deep but narrow sinus into two lobes. The lower of these lobes tapers to a long point while the other is wider and rounded. Head of the receptaculum seminis spherical; tail very long. For further details concerning the structure of the female genitalia, see Plate XXV, fig. 130.

MaLE. General structure essentially as in the female except that four antepygidial bristles are present on a side. Modified SEGMENTS: Process of the clasper broad and lobular with a number of slender bristles distally. Movable finger curved, extending slightly more distad than the process, armed with a number of small bristles. Manubrium curved, not long. Penis bladelike, its spring not completing a single turn. Posterior arm of sternite IX expanded distally and armed with numerous slender bristles. For further details concerning the structure of the male genitalia, see Plate XXV, fig. 128.

Records. ALABAMA-Dale County, April 4, 1937, on "cotton mouse," male (R. E. Dyer). FLORIDA - Tallahassee, January 15, 1938, on same host, female (B. V. Travis). IOWADubuque, November 4, 1937, on Peromyscus leucopus noveboracensis (Fischer), female; Eldon, November 12, 1237, on Sciurus carolinensis leucotis (Gapper), male, two females; 
Sabula, November 18, 1937, on Peromyscus leucopus noveboracensis (Fischer), female (T. Scott). MARYLAND Bladensburg, March 31, 1901, on "Peromyscus leucopus," male (H. S. Barber) ; College Park, February 17, 1932, on same host, male and female (R. Greenfield); Plummer Island, February 22, 1928, on same host, female (A. Wetmore) ; February 6, 1927, on same host, female (H. S. Barber); January 1, 1930, on same host, female (A. K. Fischer); December 30, 1915, on Mus musculus musculus (Linnaeus), female, two males (R. C. Shannon); Kensington, February 22, 1924, on "Microtus pennsylvanicus," female (H. S. Barber). MASSACHUSETTS Martha's Vineyard, September 7, 1936, on "Evotomys species," male; Chilmark, October 28, 1937, on Microtus pennsylvanicus pennsylvanicus (Ord), female; Gayhead, September 25, 1937, on Zapus hudsonius (Zimmerman), male; October 27, 1937, on Peromyscus leucopus fusus Bangs, female; November 16, 1937, on Microtus pennsylvanicus pennsylvanicus (Ord), male and female; same data, October 13, 1937, female; same data, October 27, 1937, female and male; Edgartown, October 29, 1937, on Peromyscus leucopus fusus Bangs, male and female; October 15, 1937, on Microtus pennsylvanicus pennsylvanicus (Ord), two females (one with two receptacula seminis!) ; October 13, 1937, on "Norway-rat," female; Vineyard Haven, September 11, 1937, on Microtus pennsylvanicus pennsylvanicus (Ord), male (C. N. Smith). TENNESSEE-Greenbriar, April 18, 1931, on Peromyscus leucopus leucopus (Rafinesque), male (R. L. Boke). VIRGINIA-East Falls Church, November 17, 1929, male and female; December 4, 1927, two females; January 7, 1927, male and female, on "Peromyscus leucopus" (E. A. Chapin) ; Petersburg, April 7, 1933, on same host, female (H. S. Peters).

EASTERn Hosts. Red-backed Mouse ("Evotomys species"), White-footed Mouse (Peromyscus leucopus noveboracensis (Fischer)), Meadow-mouse (Microtus pennsylvanicus pennsylvanicus (Ord)), "Cotton-mouse," Jumping Mouse (Zapus hudsonius hudsonius (Zimmerman)), "Norway-rat."

Eastern localities. Alabama, Iowa, Maryland, Massachusetts, Maine, Tennessee, Virginia.

Type material. Female holotype from Orono, Maine, on "Evotomys species" in the United States National Museum. Male allotype from Eldon, Iowa, an Glaucomys volans volans (Linnaeus) in the Iowa State College Collection.

This species is among the largest found in our fauna and finds 
a place with Hystrichopsylla gigas tahavuana Jordan and Tamiophila grandis (Rothschild), all three being four or five millimeters in length. Like the other two it is a parasite of small mice but it is much more abundant. Pre-eminently a fall and winter species, it has been collected from September to April, and its favorite host seems to be the white-footed mouse.

\section{PEROMYSCOPSYLLA I. FOX}

Peromyscopsylla I. Fox, 1939, Proc. Ent. Soc. Washington, 41:47.

Genotype: Ctenopsyllus hesperomys Baker

Head subangulate in front. Fronto-genal angle acute. Anterior margin of the head with a series of bristles; two, three, or four of those near the fronto-genal angle thickened and pigmented. Genal ctenidium more or less horizontal, consisting of two spines variable in size according to the species. Genal process prominent, variable in shape. Metanotum and abdominal tergites armed dorsally with short, stout teeth. Other details as in Ctenopsyllus Kolenati.

This genus is represented in the East by three species which parasitize the common small mammals.

\section{Key to the Eastern Species of Peromyscopsylla}

1. Lower genal spine extending more distad than the upper one .......2 Upper genal spine extending more distad than the lower one $P$. catatina

2. Sternite VII of the female with a deep sinus; movable finger of male not

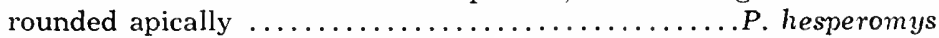

Sternite VII of the female without a deep sinus; movable finger

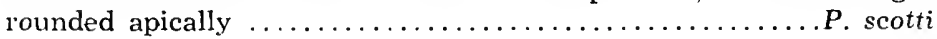

\section{Peromyscopsylla hesperomys (Baker)}

(Plate XXIII, figs. 117, 118, 119)

1904 Ctenopsyllus hesperonys Baker, Proc. United States Nat. Mus., 27: 428.

1905 Ctenopsyllus hesperomys Baker, Proc. United States Nat. Mus., 29: 136.

1914 Ctenopsyllus hesperomys C. Fox, United States Public Health Ser. Hyg. Lab., Bull. 97, Pl. XX, fig. 55.

1915 Leptopsylla hesperomys Rothschild, Nov. Zool., 22:304.

1923 Leptopsylla hesperomys Stewart, Cornell Univ. Agric. Exp. Sta., Mem. 101, p. 869.

1929 Leptopsylla hesperomys Jordan, Nov. Zool., 35:177.

1933 Leptopsylla hesperomys Stewart, Jour. New York Ent. Soc., 41:260.

1933 Leptopsylla hesperomys Jordan, Nov. Zool., 39: 62.

1939 Peromyscopsylla spinifrons I. Fox, Proc. Ent. Soc. Washington, 41:48, Pl. 6, figs. 1, 2. 
Female. Anterior margin of the head with a row of ten or eleven bristles, of which two to four are short, toothlike spiniforms, while the rest are of the usual form. Lower gena with three long bristles, above which are three well-developed bristles in series, more or less forming a diagonal across the upper portion of the head. Frons and gena further armed with numerous small setae. Upper of the two ctenidial spines much shorter than the lower and closely associated with the long spatulate genal process which extends well beyond it. Postantennal region of the head armed with four irregular rows of bristles; first row consisting of about five bristles, second, third. and fourth rows of six each. Between the second and third rows are two or three irregularly arranged bristles. Along the posterior margin of the antennal groove are a number of small setae (Plate XXIII, fig. 117). Pronotum with a single distinct row of bristles and a ctenidium of fourteen or fifteen spines on a side. Meso- and metanotum each with three or four irregular rows of bristles. Each abdominal tergite with two rows of bristles. First five abdominal tergites and the metanotum armed with two or three stout dorsal teeth on a side. Sternite VII divided by a deep sinus, the upper lobe prominent, more or less triangular, the lower lobe wider. Tail of the receptaculum seminis about three-fifths as long as the head, which is oval and gradually merges into the tail. For further details concerning the structure of the female genitalia, see Plate XXIII, fig. 118.

MaLE. Chaetotaxy of the head in the specimens examined differing somewhat from that of the female. Anterior border of the head armed with eight or nine bristles, of which the first three in the vicinity of the fronto-genal angle are heavily pigmented and spiniform. Five long bristles situated in the upper region of the head while the lower region bears three long, stout bristles. Numerous small setae irregularly scattered over the preantennal region of the head. Lower of the two genal spines extending slightly more distad than the upper. Genal process sometimes spatulate and sometimes rather slender, extending well beyond the rounded termination of the upper genal spine. Postantennal region of the head with about five irregular rows of bristles; first row consisting of two bristles, second of three. third of four, fourth of five, and the fifth or marginal row of about seven. A series of about eight setae along the posterior margin of the antennal groove. Modified SEgments: Genitalia closely resembling those of $P$. catatina (Jordan); the movable finger differing in shape, being widest below the middle and 
tapering apically. Posterior margin of the movable finger armed with three robust bristles and two or three smaller ones, anterior margin armed with about five weak bristles. Apex of posterior arm of sternite IX rather abruptiy pointed, its posterior margin with three long bristles and a number of small ones. For further details of the structure of the male genitalia. see Plate XXIII, fig. 119.

RECORD. NEW HAMPSHIRE - Mount Chocorua, Carroll County, October 1, 1926, on Peromyscus maniculatus gracilis (LeConte), female (F. Harper).

EAstern Hosts. White-footed Mouse (Peromyscus leucopus noveboracensis (Fischer), etc.), "Kingfisher's nest."

Eastern localities. New Hampshire, New York, Pennsylvania, Tennessee.

Type material. Female holotype from Franconia, New Hampshire, on "Peromyscus" in the United States National Museum.

\section{Peromyscopsylla scotti I. Fox}

(Plate XXII, figs. 111, 112, 113)

1939 Peromyscopsylla scotti I. Fox, Proc. Ent. Soc. Washington, 41:49. Pl. 6, figs. 4, 5.

Female. Chaetotaxy of the head essentially as in P. hesperomys. Lower of the two genal spines extending only slightly more distad than the upper. Genal process spatulate and prominent (Plate XXII, fig. 111). Each abdominal tergite armed with one to three short, stout teeth on a side, the anterior tergites usually with more teeth than the posterior. Four antepygidial bristles present on a side. Sternite VII unlike that of $P$. hesperomys, without a deep sinus, and its margin irregular in outline. Receptaculum seminis of characteristic shape; tail about as long as the head which is about twice as long as wide. For further details concerning the structure of the receptaculum seminis, see Plate XXII, fig. 113.

MaLE. Chaetotaxy of the head and general structure as in the female. Modified Segments: Process of the clasper rounded, armed with three or four slender bristles. Movable finger rounded apically with three robust bristles and a number of smaller ones. Posterior arm of sternite IX with numerous setae on the posterior margin. For further details concerning the structure of the male genitalia, see Plate XXII, fig. 112.

RECORDS. MASSACHUSETTS - Edgartown, November 13, 
1937, on Peromyscus leucopus fusus Bangs, male; October 29, 1937, female (C. N. Smith).

EASTERN Host. White-footed Mouse (Peromyscus leucopus noveboracensis (Fischer), etc.).

Eastern localities. Iowa, Massachusetts.

Type material. Female holotype from Peromyscus leucopus noveboracensis (Fischer) at Dubuque, Iowa, and male allotype (described above) from Edgartown. Massachusetts. in the United States National Museum.

Peromyscopsylla catatina (Jordan)

(Plate XXII, figs. 110, 114, 115)

1928 Leptopsylla catatina Jordan, Nov. Zool., 34:186, fig. 10.

1929 Leptopsylla catatina Jordan, Nov. Zool,, 35:171.

1933 Ctenopsyllus catatina Stewart, Jour. New York Ent. Soc., 41: 259.

1937 Leptopsylla catatina Jordan, Nov. Zool., 40:285.

MaLe. Bristles of the pre- and postantennal regions of the head arranged essentially as in P. hesperomys. Upper of the two genal spines more recurved and extending further distad than the lower. Genal process not markedly spatulate, and extending slightly more distad than the upper genal spine, if at all (Plate XXII, fig. 114). Pronotum with a single row of bristles and a ctenidium of about thirteen spines on a side. Meso- and metanotum each with four rows of bristles. Metanotum and first five abdominal tergites armed with three or four short stout dorsal teeth on a side; sixth abdominal tergite armed with one to three such teeth on a side. Three antepygidial bristles present on a side, the middle by far the longest. ModifiEd SEGMENTS: Upper region of the clasper more or less triangular, no well-defined process set off. Movable finger with the posterior margin more or less rounded, the anterior margin also convex but to a lesser degree. Posterior margin of the movable finger armed with two or three long bristles and several smaller ones. Manubrium slender, about as long as the penis. Penis broad and bladelike, its spring not long. Sternite IX expanded distally, the apex subacuminate; armed on the posterior margin with five or six long bristles and many smaller ones. For further details concerning the structure of the male genitalia, see Plate XXII, fig. 115.

Female. General structure essentially as in the male. Abdominal sternite VIII armed with numerous bristles varying in size. Sternite VII with a small angular lobe projecting posteriorly which varies in shape, the margin below the lobe convex 
(Plate XXII, fig. 110). Receptaculum seminis essentially as in P. hesperomys.

Records. MAINE-Mount Katahdin, August 26, 1928, on "Evotomys gapperi ochradelus," male and female (F. Harper). MARYLAND-College Park, February 17, 1932, female (R. Greenfield). MASSACHUSETTS-Ashburnham, October 12, 1927, female (F. Harper). NEW HAMPSHIRE-Mount Chocorua, Carroll County, Ociober 1, 1926, female (F. Harper).

EAstern hosts. Opossum ("Didelphis virginiana"), Hairytailed Mole (Parascalops breweri (Bachman)), Short-tailed Shrew ("Blarina brevicauda"), Meadow-mouse ("Microtus pennsylvanicus"), Red-backed Mouse ("Evotomys gapperi").

Eastern localities. Maine, Maryland, Massachusetts, New Hampshire, New York, Pennsylvania.

Type material. Female holotype from Rolling Rock Club, Ligonier, Pennsylvania, on "Didelphis virginianus" in the N. C. Rothschild Collection (British Museum).

\section{CTENOPSYLLUS KOLENATI}

Ctenopsyllus Kolenati, 1863, Horae Soc. Ent. Ross., 2: 37.

Genotype: Pulex segnis Schönherr

Head angulate in front, the frontal tubercle absent. Frons with two or more spiniforms near the frontal angle. Eye vestigial. Genal ctenidium consisting of four unequal spines. Three or four antepygidial bristles present on a side. Posterior margin of the hind tibia armed with a series of about fourteen medium-sized bristles, among which are three or four long bristles (Plate XXIV, fig. 123). Fifth tarsal segment of each leg armed with four pairs of lateral plantar bristles and a basal submedian pair.

This genus is represented in the East by a single introduced species parasitic on rats and mice. The species is not uncommon in the southeastern states but has not as yet penetrated to the interior, according to the records available. It is said to stand alone among rodent fleas in refusing to attack man.

\section{Ctenopsyllus segnis (Schönherr)}

(Plate XXIV)

1811 Pulex segnis Schönherr, Kongl, Svenska Vetenskakad. Nya. Handl. (2nd s.), 32: 98, Pl. V, figs. A, B.

1832 Pulex musculi Duges, Ann. d. Sci. Nat. (1st s.), 27:163. 
1856 Ctenophthalmus musculi Kolenati, Die Parasiten der Chiropteren, p. 33.

1895 Typhlopsylla musculi Baker, Can. Ent., 27:190.

1896 Typhlopsylla mexicana Baker, Can. Ent., 28:85.

1904 Ctenopsyllus mexicanus Baker, Proc. United States Nat. Mus., 27: 430.

1905 Ctenopsyllus musculi Baker, Proc. United States Nat. Mus., 29:136.

1910 Leptopsylla musculi C. Fox, United States Mar. Hosp. Ser., Bull. 30: 140, Pl. IV, figs. 1-5.

1914 Ctenopsyllus musculi C. Fox, United States Public Health Ser. Hyg. Lab., Bull. 97, Pl. XV, fig. 26; Pl. XX, fig. 54.

1925 Leptopsylla musculi C. Fox, United States Public Health Ser., Rep. 40:1922.

1925 Leptopsylla musculi C. Fox, Insects and Disease of Man, p. 140, fig. 67.

1928 Leptopsylla musculi Stewart, Cornell Univ. Agric. Exp. Sta., Mem. 101, p. 869.

1929 Leptopsylla segnis Hasseltine, United States Public Health Ser., Rep. 44:583.

1931 Leptopsyllus musculi C. Fox, United States Public Health Ser., Rep. 46:574.

1933 Ctenopsyllus segnis Stewart, Jour. New York Ent. Soc., 41:259.

1934 Ctenopsyllus segnis Shaftesbury, Jour. Elisha Mitchell Sci. Soc., 49: 256.

1935 Leptopsylla musculi Vogel and Cadwallader, Unied States Public Health Ser., Rep. 50:1953.

MaLe. Anterior margin of the head with a series of nine bristles, of which two are robust spiniforms. Five other long bristles present, arranged as in Plate XXIV, fig. 125. Preantennal region of the head further armed with numerous small setae. Most dorsal of the four genal spines the broadest; the third genal spine the longest. Labial palpus extending more than halfway down the length of the fore coxa. Postantennal region of the head with four rows of bristies, of which the first consists of three or four bristles, the second and third of four or five, and the fourth of six. Pronotum armed with a single row of bristles and a ctenidium of about eleven spines on a side. Meso- and metanotum each armed with three or four irregular rows of bristles. Each abdominal tergite armed with two rows of bristles, one consisting of short bristles and the other of long ones. Modified Segments: Dorsal region of the clasper lobular, no distinct process set off. Movable finger rounded at the posterior margin and armed with six bristles, of which three are longer than the others. Manubrium rather long and curved distally. Penis broad and bladelike; spring long. Paramere of the penis large and conspicuous. Distal end of the posterior arm of sternite IX expanded, the posterior margin with a number of 
hairlike setae. For further details concerning the structure of the male genitalia, see Plate XXIV, figs. 122, 124.

Female. Chactotaxy of the head and general structure as in the male except that four antepygidial bristles are present, two short ones and two long ones. Sternite VII without a sinus. Head of the receptaculum seminis much longer than wide. Fo: further details concerning the structure of the female genitalia, see Plate XXIV, fig. 126.

RECORDS, FLORIDA-Jacksonville, January 25, 1934, on Rattus norvegicus (Erxleben), numerous specimens; Melbourne, April 6, 1909, on same host, female; Tallahassee, July 12, 1937, on "Rattus alexandrinus," male; January 16, 1937, on "Rattus rattus," two males, two females; January 20, 1937, on "Mus musculus," male, two females; January 17, 1937, on "Peromyscus gossypinus," male and female. LOUISIANAJeanerette, February 23, 1927, on same host, male (Dikeman). SOUTH CAROLINA-Folly Beach, Charleston County, January 2, 1938, on "Mus species," two males (D. G. Nichols) .

EASTERN HOSTS. House-rat (Rattus norvegicus (Erxleben)). House-mouse (Mus musculus musculus (Linnaeus)), Roof-rat ("Rattus alexandrinus"), Cotton-rat ("Sigmodon hispidus"). Black Rat ("Rattus rattus"), White-footed Mouse ("Peromyscus gossypinus").

Eastern localities. Florida, Georgia, Louisiana, Massachusetts, New York, North Carolina, Pennsylvania, Rhode Island. Virginia, (Mexico, Europe).

Type Material. Twenty specimens from "Mus musculus" at Sweden. Location of types not ascertained.

\section{NEARCTOPSYLLA ROTHSCHILD}

Nearctopsylla Rothschild, 1915, Nov. Zool., 22: 307.

\section{Genotype: Ctenopsyllus brooksi Rothschild}

Frontal tubercle absent. A genal and a pronotal ctenidium present. Genal comb vertical composed of five spatulate spines. Eye absent. Labial palpus composed of five segments. One or two long antepygidial bristles present on a side. Fifth tarsal segment of fore and middle legs with five pairs of lateral plantar bristles; fifth tarsal segment of the hind legs with four pairs of lateral plantar bristles.

This genus is represented in the East by a single species known from various small mammals. 
Nearctopsylla genalis (Baker)

(Plate XXIII, figs. 116, 120, 121)

1904 Ctenophthalmus genalis Baker, Proc. United States Nat. Mus., 27:424.

1904 Ctenopsyllus hygini Rothschild, Nov. Zool., 11:650, Pl. XV, fig. 85; Pl. XVI, figs. 93, 94.

1905 Ctenophthalmus genalis Baker, Proc. United States Nat. Mus., 29:135. 1914 Ctenopsylla genalis C. Fox, United States Public Health Ser. Hyg. Lab., Bull. 97, Pl. XV, fig. 25; Pl. XX, fig. 56.

1923 Ctenophthalmus genalis Dunnam, Ent. News, 34:219.

MaLE. Front of head flattened and more or less vertical. Preantennal region with a row of five bristles extending obliquely anteriorly from the dorsal region of the antennal groove. Frons with a long bristle close to the anterior border and opposite the third genal spine. Genal ctenidium with five spatulate spines. First ctenidial spine shortest, the middle three longest; fifth spine truncate, the others more or less acuminate. Labial palpus extending to three-fourths the length of the anterior coxae. Postantennal region of the head with three rows of four to six bristles each. Pronotum armed with a single row of bristles and a pronotal ctenidium of thirteen or fourteen spines on a side. Meso- and metanotum each with one or two rows of bristles. Each abdominal tergite with a marginal row of long bristles. The anterior tergites may have, in addition, an anterior row consisting of a few short bristles. First four abdominal tergites further armed with one or two short, stout teeth on a side. One stout antepygidial bristle mounted on a tubercle on each side. Modified SEgments: Clasper armed apically with a number of bristles of various sizes, and on the inside surface with many small setae. Movable finger armed on the posterior margin with four or five long bristles and a few short ones. Manubrium small, curved, tapering to a delicate point. Penis broad and heavy, curved distally and ending in a sharp point; spring long, not completing a turn. Sternite IX with a brush of seven or eight bristles on the posterior margin. For further details concerning the structure of the male genitalia, see Plate XXIII, fig. 121.

Female. Chaetotaxy of the head essentially as in the male (Plate XXIII, fig. 116). Two long antepygidial bristles present on a side. Sternite VII divided into two lobes by a wide sinus, the upper lobe more prominent than the lower. Tail of the receptaculum seminis very long and wide. For further details concerning the structure of the female genitalia, see Plate XXIII, fig. 120 . 
Records. IOWA-Baxter, April, 1923, no host given, female (J. W. Preston). MASSACHUSETTS-Ashburnham, October 12, 1927, on Blarina brevicauda talpoides (Gapper), female (F. Harper). NEW HAMPSHIRE - Carroll County, October 4, 1926, on same host, female (F. Harper). MINNESOTA-No further data, September 28, 1933, on "Blarina brevicauda," male.

EASTERN HOSTS. Short-tailed Shrew (Blarina brevicauda talpoides (Gapper)), Pocket Gopher (Geomys bursarius (Shaw) ), "Moles."

Eastern Localities. Iowa, Massachusetts, Michigan, New Hampshire, Minnesota.

Type material. Male holotype from Agricultural College, Michigan, on Geomys bursarius (Shaw) according to the literature on "Scalops" according to the slide, in the United States National Museum.

\section{DORATOPSYLLA JORDAN AND ROTHSCHILD}

Doratopsylla Jordan and Rothschild, 1912, Nov. Zool., 19:62.

Genotype: Typhlopsylla dasycnemus Rothschild

Frontal tubercle absent. Eye vestigial. Genal ctenidium consisting of four spines. Labial palpus composed of four segments. Frons rounded, armed with two rows of conspicuous bristles. Fifth tarsal segment of all tarsi armed with four pairs of lateral plantar bristles and a basal median pair. Three antepygidial bristles usually present on a side.

This genus is represented in the East by two shrew fleas which may be separated by the following key:

\section{Key to the Eastern Species of Doratopsylla}

Last genal spine more or less horizontal, closely appressed to the genal

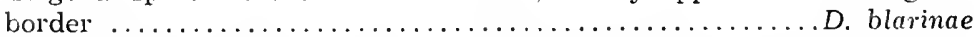
Last genal spine oblique, forming an angle with the genal border .......

.D. curvata

\section{Doratopsylla blarinae C. Fox \\ (Plate XXVI, figs. 134, 135, 137)}

1914 Doratopsylla blarinae C. Fox, United States Public Health Ser. Hyg. Lab., Bull. 97:11, Pl. IV, figs. 1-3.

1915 Doratopsylla blarinae Rothschild, Ectoparasites, 1:28.

1919 Doratopsylla blarinae Chapin, Bull. Brooklyn Ent. Soc., 14:54.

1925 Doratopsylla blarinae Ewing, Jour. Parasitology, 12: 43.

1928 Doratopsylla blarinae Jordan, Nov. Zool., 34:186. 
1929 Doratopsylla blarinae Jordan, Nov. Zool., 35:177.

1933 Doratopsylla blarinae Jordan, Nov. Zool., 39:63.

1933 Doratopsylla blarinae Stewart, Jour. New York Ent. Soc., 41:260.

MaLe. Preantennal region of the head with two rows of bristles; upper row with five bristles, lower row with three much longer bristles and two small setae. Genal ctenidium consisting of four spines of which the last two are the longest. Second antennal joint with three or four slender setae. Postantennal region of the head with three rows of long bristles, of which the first consists of three bristles, the second of four, and the third of five or six. Pronotum with a single row of bristles and a ctenidium of about eight spines on a side. Meso- and metanotum each with two irregular rows of bristles. Each abdominal tergite armed with two irregular rows of bristles; the anterior tergites further armed with a single short, stout tooth on a side. Three antepygidial bristles present on a side; of these the middle is by far the longest. Modified SEGMents: Process of the clasper divided into two lobes, the anterior very small with three bristles, of which the most dorsal is longest and stoutest. Posterior lobe much more conspicuous, rather long and curved dorsad. Movable finger very long and slender, armed with several slender bristles on its posterior margin (Plate XXVI, fig. 137). Manubrium short and heavy, roughly triangular and ending in a curved point. Penis not much longer than the manubrium, curved and bladelike; spring long but not completing a turn. Posterior process of sternite IX expanded apically, the posterior margin with a short spinelike bristle, above which are several other more slender bristles.

Female. Chaetotaxy of the head essentially as in the male (Plate XXVI, fig. 134). Sternite VII without a distinct sinus. Tail of the receptaculum seminis very short; head long and broad, more or less oval in outline. For further details concerning the structure of the female genitalia, see Plate XXVI, fig. 135 .

RECORDS. CONNECTICUT-Woodstock, September 5, 1927, on Blarina brevicauda talpoides (Gapper), female (F. Harper). DISTRICT OF COLUMBIA - Washington, September 20, 1929, on "Peromyscus leucopus," male (J. C. Jones). MAINEToque Pond, August 21, 1928, on "Sorex palustris albibarbis," female (F. Harper). MARYLAND-Cabin John, June 1, 1932, on "Blarina brevicauda," two females; Chillum, May 19, 1932, on same host, two males; College Park, June 16, 1932, male; April, 1932, on same host, male and female; Silver Spring, 
March 1, 1932, on same host, male, three females; Takoma Park, April 19, 1932, on same host, male, four females; Burnt Mills, March, 1932, on same host, numerous specimens (R. Greenfield). MASSACHUSETTS - Edgartown, June 10, 1936, on "Microtus pennsylvanicus," female (F. C. Bishopp).

EASTERN HOSTS. Short-tailed Shrew (Blarina brevicauda talpoides (Gapper), etc.), Meadow-mouse ("Microtus pennsylvanicus"), White-footed Mouse ("Peromyscus leucopus"), Water Shrew ("Sorex palustris albibarbis").

EAstern localities. Connecticut, District of Columbia, Maine, Maryland, Massachusetts, New York, Pennsylvania, Virginia.

Type Material. Male holotype from Washington, D. C., on "Blarina brevicauda" in the United States National Museum.

During spring and summer this species occurs abundantly on shrews in the East. In the Middle West, however, it is replaced by the following species:

\section{Doratopsylla curvata Rothschild" \\ (Plate XXVI, figs. 133, 136, 138)}

1915 Doratopsylla curvata Rothschild, Ectoparasites, 1:25, figs. 28, 29.

1925 Doratopsylla curvata Ewing, Jour. Parasitology, 12: 43.

1929 Doratopsylla curvata Ewing, Manual External Parasites, p. 158, fig. 89.

1929 Doratopsylla (Corrodopsylla) curvata Wagner, Konowia, 8:317.

1929 Doratopsylla curvata Jordan, Nov. Zool., 35: 172.

1933 Doratopsylla curvata Stewart, Jour. New York Ent. Soc., 41:260.

MALE. Preantennal region of the head with two rows of bristles; upper row consisting of five short bristles, lower row consisting of three bristles, of which two are long and one is short. Between the two long bristles are four short setae. Fourth spine of the genal ctenidium separated from the genal border, extending obliquely backward. Genal process long and slender, very conspicuous, extending further posteriorly than the last genal spine. Postantennal region of the head armed with three rows of bristles, each row consisting of five or six bristles. Pronotal ctenidium consisting of about nine spines on a side. Each abdominal tergite armed with two rows of bristles. In addition, each of the first four tergites bears a long spinelike dorsal bristle. Tergite VII produced into an acuminate heavily sclerotized process which extends between the two sets of three antepygidial bristles. Modified segments: Genitalia differing markedly from those of $D$. blarinae. Upper portion of the

* Wagner (1929) is of the opinion that this species represents a distinct subgenus to which he has given the name, Corrodopsylla. 
clasper divided into two conspicuous processes of about the same length, between which is a small lobe. Anterior process slender and with two long, stout bristles distally. Posterior process much wider and more or less triangular in shape, armed with two small bristles distally. Movable finger slightly wider basally than distally, strongly curved; the posterior margin with several slender bristles (Plate XXVI, fig. 138). Manubrium triangular, tapering to a point. Penis broad and heavy, blunt terminally; spring very short, extending only slightly beyond the penis.

Female. Chaetotaxy of the head (Plate XXVI, fig. 133) and general structure essentially as in the male. Ventral portion of sternite VII divided by a deep sinus into two lobes, of which the upper is acuminate while the lower ends bluntly. Tail of the receptaculum seminis longer than in D. Blarinae; about onehalf as long as the ovate head. For further details concerning the structure of the female genitalia, see Plate XXVI, fig. 136.

RECORDS. IOWA-Ames, July 4, 1936, "in short-tailed shrew nest," six females, three males (R. L. Roudabush); Ruthven, June--July, 1938, on "shrew," numerous specimens (E. R. Becker and P. C. Waters). IMINNESOTA-Saint Paul, November 10, 1919, "in soil," male (H. E. Ewing). (MONTANARavalli County, October 20, 1935, "in shrew nest," male and female (W. L. Jellison).)

EASTERN host. Short-tailed Shrew ("Blarina brevicauda").

Eastern localities. Iowa, Minnesota, New York, (Montana).

Type material. Male and female from Iowa City, Iowa, on "Blarina brevicauda" in the N. C. Rothschild Collection (British Museum).

\section{EPITEDIA JORDAN}

Epitedia Jordan, 1938, Nov. Zool., 41:124.

Genotype: Ctenopthalmus wenmanni Rothschild

Both a genal and a pronotal ctenidium present. Frontal notch prominent. Frons with two rows of bristles. Eye vestigial. Genal ctenidium consisting of two unequal spines, one overlapping the other. Fifth tarsal segment of the fore and middle legs with four pairs of lateral plantar bristles and a basal submedian pair; fifth tarsal segment of the hind legs with four pairs of lateral plantar bristles and without a basal submedian pair.

This genus is represented in the East by three species known 
from various small mammals. Unfortunately, E. faceta and E. testor are very rare; in fact, only the female of the latter species has been described, while the former species is known from but one pair. The males of E. faceta and E. wenmanni may be separated by the following key:

Movable finger longer than the distance from its base to the tip of the lower lobe of the clasper ....................... venmanni

Movable finger not longer than the distance from its base to the tip of the lower lobe of the clasper $\ldots \ldots \ldots \ldots \ldots \ldots \ldots \ldots \ldots \ldots$. faceta

\section{Epitedia wennanni (Rothschild)}

(Plate I; Plate XXVII, figs. 139, 142, 144)

1904 Ctenophthalmus wenmanni Rothschild, Nov. Zool., 11:642, Pl. XIV, figs. $75,76,77$.

1919 Neopsylla similis Chapin, Bull. Brooklyn Ent. Soc., 14:50.

1919 Neopsylla wenmanni Chapin, Bull. Brooklyn Ent. Soc., 14:50.

1926 Ctenophthalmus wenmanni Stewart, Cornell Univ. Agric. Exp. Sta., Mem. 101, p. 869.

1929 Neopsylla wenmanni Jordan, Nov. Zool., 35: 172.

1933 Neopsylla wennıanni Jordan, Nov. Zool., 39:62.

1937 Neopsylla wenmanni Jordan, Nov. Zool., 40: 285.

1938 Epitedia wenmanni Jordan, Nov. Zool., 41:124.

MaLe. Frontal tubercle roughly triangular, not extending beyond the margin of the head. Preantennal region of the head with two rows of bristles; upper row with five bristles, lower row with four, of which three are very long. Genal ctenidium consisting of two spines, of which one is slightly more than one-half as long as the other which is much more slender. Genal process long but not heavily pigmented. Labial palpus slightly more than one-half as long as the anterior coxa. Second antennal segment with seven or eight short bristles. A series of eight or nine short setae present along the posterior edge of the antennal groove. Postantennal bristles arranged in three rows each consisting of five or six bristles. Pronotum armed with a row of bristles of various sizes and a ctenidium of six or seven spines on a side. Meso- and metanotum each with three or four rows of irregularly arranged bristles. Each abdominal tergite with two rows of bristles, the posterior row consisting of alternating long bristles and short setae. In addition, some of the abdominal tergites armed with one tooth on a side. Three antepygidial bristles present on a side. Modified SEGMENTS: Process of the clasper bilobed, the upper lobe longer than the lower lobe. Both the upper and lower lobe with a long bristle distally and a number of shorter bristles. Movable finger 
roughly triangular, rounded ventrally, the posterior margin with a number of bristles of various sizes. Manubrium long, distally slender, and in some specimens extending slightly more distad than the penis. Penis broad, ending in a curved point; spring not completing a single turn. Posterior arm of sternite IX wider basally than apically where it is armed with about nine spinelike bristles of various sizes. For further details concerning the structure of the male genitalia, see Plate XXVII, fig. 144 .

Female. General structure including chaetotaxy of the head as in the male (Plate XXVII, fig. 139). Sternite VII divided by a wide sinus into two lobes of which the upper is more acuminate and extends further distad than the rounded lower one. Head of the receptaculum seminis about twice as long as wide. For further details concerning the structure of the female genitalia, see Plate XXVII, fig. 142.

RECORDS. DISTRICT OF COLUMBIA- February 5, 1930, on Peromyscus leucopus noveboracensis (Fischer), two males (A. H. Howell). GEORGIA-Lumpkin County, October 21, 1935, on "Neotoma floridana," male, two females (F. Harper). IOWA-Osceola, March 18, 1936, on "field mouse," female (G. S. Cantonwine); Ames, March 15, 1938, on "white-footed mouse," male; February 5, 1938, male; December 5, 1937, male; March 3, 1938, male (I. Fox); July, 1933, on "thirteen-striped ground squirrel," five females (R. L. Roudabush); Luxemburg, November 23, 1937, on Glaucomys volans volans (Linnaeus), five females; Dubuque, November 2, 1937, on Peromyscus leucopus noveboracensis (Fischer), male; Dyersville, November 4, 1937, on same host, female; Luxemburg, November 23, 1937, on same host, female (T. Scott). KENTUCKY-Mammoth Cave, July 3, 1929, on "Neotoma species," female; Dixon Cave, July 20, 1929, male, three females (L. Giovannoli). MAINE - Lucerne-in-Maine, November 1, 1928, on Blarina brevicauda talpoides (Gapper), male (F. Harper). MARYLAND-Bell, July 8, 1927, on "starling," female; Bladensburg, March 31, 1901, in nest of "Peromyscus leucopus," male (H. S. Barber); College Park, February, 1932, on same host, three males, three females; Takoma Park, April 28, 1932, on same host, male and female (R. Greenfield). MASSACHUSETTSAshburnham, October 12, 1927, on "Evotomys gapperi," female; Muskegeti, June 18, 1926, on Microtus breweri (Baird), female. NEW HAMPSHIRE-Kinsman's Notch, August 22, 1927, on Peromyscus maniculatus gracilis (LeConte), male; Carroll 
County, October 4, 1926, on "Evotomys gapperi," male (F. Harper). NEW YORK - Elma, Erie County, December 16, 1925, on "Mustela cicognanii," female (A. Hardy). TENNESSEE-Greenbriar, April 18, 1931, on Blarina brevicauda talpoides (Gapper), female, two males (R. L. Boke). VIRGINIA -Great Falls, February 17, 1907, in nest of "Peromyscus leucopus," numerous specimens (D. H. Clemons); East Falls Church, January 7, 1927, on Peromyscus leucopus noveboracensis (Fischer), two males (E. A. Chapin).

EASTERN Hosts. Short-tailed Shrew (Blarina brevicauda talpoides (Gapper)), Wood-rat (Neotoma floridana (Ord), etc.), "Field-mouse," White-footed Mouse (Peromyscus leucopus noveboracensis (Fischer), etc.), "Thirteen-striped Ground Squirrel," Flying Squirrel (Glaucomys volans volans (Linnaeus)), Red-backed Mouse ("Evotomys gapperi"), Meadow-mouse (Microtus breweri (Baird)), Weasel ("Mustela cicognanii," etc.), Hairy-tailed Mole (Parascalops breweri (Bachman)), House-rat (Rattus norvegicus (Erxleben)).

Eastern localities. District of Columbia, Georgia, Iowa, Kentucky, Maine, Maryland, Massachusetts, Minnesota, New Hampshire, New York, North Dakota, Tennessee, Virginia, (New Brunswick).

Type material. One male from British Columbia on "Peromyscus leucopus," and one female from the same locality on "Neotoma cinerea" in the N. C. Rothschild Collection (British Museum).

This species seems to be pre-eminently a flea of the whitefooted mouse, but is abundant on many other small mammals. It occurs as an adult in some part of our territory during every season of the year; indeed the above records show that it has been found in this stage during practically every month. Its hardihood is attested by the fact that it has been taken in great numbers from white-footed mice in the midst of a rigorous Iowa winter and that it is known from as far north as New Brunswick.

\section{Epitedia faceta (Rothschild)}

(Plate XXVII, figs. 141, 143)

1915 Neopsylla faceta Rothschild, Ectoparasites, 1:32.

1929 Neopsylla faceta Jordan, Nov. Zool., 35:176.

1938 Epitedia faceta Jordan, Nov. Zool., 41:124.

No specimen of this species or of $E$. testor has been available for study. The following descriptions are based on Rothschild's 
original descriptions and the accompanying figures are redrawn from his illustrations.

MaLE. Chaetotaxy of the head as in E. wenmanni except that the middle row of the postantennal region consists of but two or three bristles. Labial palpus reaching almost to the apex of the fore coxa. Other details of general structure essentially as in E. wenmanni. Modified Segments: Process of the clasper bilobed, each lobe with numerous bristles. Movable finger with the posterior margin obtusely angulate in the middle and with two stout curved bristles at this place; posterior margin further armed with numerous slender setae. Posterior arm of sternite IX with a row of four spiniforms at the apex near which are three smaller spiniforms and some setae. For further details concerning the structure of the male genitalia, see Plate XXVII, fig. 141.

Female. General structure and chaetotaxy essentially as in the male. Sternite VII with a wide but shallow sinus, the two lobes of approximately the same size. Head of the receptaculum seminis long and sausage-shaped, much longer than the tail. For further details of the structure of the female genitalia, see Plate XXVII, fig. 143.

EASTERN host. Red Squirrel ("Sciurus hudsonicus").

EASTERN LOCALITY. Massachusetts.

Type material. Male and female from Wilbraham, Massachusetts, on "Sciurus hudsonicus" in the N. C. Rothschild Collection (British Museum).

\section{Epitedia testor (Rothschild) \\ (Plate XXVII, fig. 140)}

1915 Neopsylla testor Rothschild, Ectoparasites, 1:34, fig. 36.

1926 Neopsylla testor Stewart, Cornell Univ. Agric. Exp. Sta., Mem. 101, p. 869.

1929 Neopsylla testor Jordan, Nov. Zool., 35: 177.

1933 Neopsylla testor Stewart, Jour. New York Ent. Soc., 41:261.

1938 Epitedia testor Jordan, Nov. Zool., 41:124.

Female. General structure and chaetotaxy essentially as in $E$. faceta, the difference between the species being in the structure of the genitalia. Sternite VII bearing on both sides together six long and seven short bristles; divided into two lobes by a shallow sinus, the upper lobe slightly narrower than in faceta. For further details of the structure of the female genitalia, see Plate XXVII, fig. 140.

MALE. Undescribed. 
Eastern host. "Nest (of mouse?)."

Eastern locality. New York.

Type material. Female holotype collected at Lansingburgh. near Troy, New York, in the N. C. Rothschild Collection (British Museum).

\section{TAMIOPHILA JORDAN}

Tamiophila Jordan, 1938, Nov. Zool., 41:124.

\section{Genotype: Typhlopsylla grandis Rothschild}

Genal spines as in Epitedia Jordan. Eye vestigial. Pronotal ctenidium consisting of about eleven spines on a side. Each abdominal sternite armed with a row of six or seven bristles anterior to which are numerous slender setae. Fifth tarsal segment of the fore and middle legs armed with five pairs of lateral plantar bristles, without a basal submedian pair. Fifth tarsal segment of the hind legs armed with four pairs of lateral plantar bristles, without a basal submedian pair. Size large, four or five millimeters in length.

This genus is represented in the East by a single giant species which occurs on various rodents.

\section{Tamiophila grandis (Rothschild)}

(Plate XXV, figs. 127, 129, 131)

1902 Typhlopsylla grandis Rothschild, Ent. Rec., 14: 62, Pl. II, fig. 3.

1895 Pulex gigas Baker, Can. Ent., 27:163 (not Pulex gigas Kirby).

1896 Pulex gigas Osborn, United States Dept. Agric. Div. Ent., Bull. 5 (new ser.), p. 152 (not Pulex gigas Kirby).

1904 Ctenophthalmus gigas Baker, Proc. United States Nat. Mus., 27:421 (not Pulex gigas Kirby).

1905 Ctenophthalmus gigas Baker, Proc. United States Nat. Mus., 29:135 (not Pulex gigas Kirby).

1926 Neopsylla striata Stewart, Insec. Insc. Menst., 14:124.

1928 Ctenophthalmus gigas Stewart, Cornell Univ. Agric. Exp. Sta., Mem. 101, p. 869 (not Pulex gigas Kirby).

1928 Neopsylla striata Stewart, Cornell Univ. Agric. Exp. Sta., Mem. 101, p. 869.

1929 Neopsylla grandis Jordan, Nov. Zool., 35:172.

1933 Neopsylla grandis Stewart, Jour. New York Ent. Soc., 41:260.

1937 Neopsylla grandis Jordan, Nov. Zool., 40:285.

1938 Tamiopinila grandis Jordan, Nov. Zool., 41:124.

Female. Frontal tubercle minute. Preantennal region of the head with two oblique rows of bristles; the upper row consisting of seven or eight, the lower of three much more robust ones. 
First genal spine much shorter and broader than the other. Postantennal region of the head with three oblique rows of bristles, the first row consisting of five or six, the second of seven or eight, and the third of about seven. Postericr to the antenna along the antennal groove are numerous long hairlike setae (Plate XXV, fig. 131). Pronotum with two rows of bristles, and a ctenidium of about ten or eleven spines on a side. Meso- and metanotum each with numerous irregularly arranged bristles in addition to the marginal row. Each abdominal tergite armed with three rows of bristles; in addition, the anterior tergites may be armed with one to several short, stout dorsal teeth on a side. Three long, antepygidial bristles present on a side. Head of the receptaculum seminis broad and long, more or less oval in shape. Sternite VII without a sinus, the posterior margin truncate. For further details concerning the female genitalia, see Plate XXV, fig. 129, which was drawn from a specimen taken off "Tamias striatus" at Branchtown, Ontario, Canada, (G. F. Dippie), loaned through the courtesy of Dr. Karl Jordan.

MALE. In the absence of a specimen for study, the following description and the accompanying illustration are taken from Rothschild's original description. Frontal and dorsal portions of the head covered with numerous hairlike setae. First four abdominal tergites with two or three teeth on a side dorsally. Sternites with hairlike setae ventrally, the hairy area extending basally beyond the middle of each segment. ModifiEd SEGMENTs: Process of the clasper tongue-shaped with numerous setae on the margins. Movable finger more or less boot-shaped with the apex truncate, its ventro-distal margin compressed carniform and clothed with setae. Manubrium long and slender, curved distally. Sternite IX boomerang-shaped, bearing numerous setae of various sizes ventrally, the more apical ones spiniform. For further details concerning the structure of the male genitalia, see Plate XXV, fig. 127.

EASTERN HOSTS. Chipmunk (Tamias striatus lysteri (Richardson)), "Cottontail Rabbit," Red Squirrel (Sciurus hudsonicus loquax Bangs), Weasel (Mustela noveboracensis noveboracensis (Emmons)).

Eastern localities. Massachusetts, New York, Michigan, (Canada).

Type Material. Several specimens from Branchtown, Ontario, Canada, on "Tamias striatus" in the N. C. Rothschild Collection (British Museum). 


\section{CATALLAGIA ROTHSCHILD}

Catallagia Rothschild, 1915, Ectoparasites, 1:41.

\section{Genotype: Pulex charlottensis Baker}

Frontal tubercle prominent, peglike, and acuminate. Eye vestigial. Pronotal ctenidium consisting of about seven spines on a side. Inner surface of the hind coxa with a patch of short spines. Fifth segment of the fore and middle tarsi with four lateral pairs of plantar bristles and a basal ventral pair; fifth segment of the hind tarsi with four lateral pairs, the ventral pair absent.

This genus is represented in the East by two rare species which occur on wild mice. Each is known from one sex only. In the absence of adequate material it is best to leave them as originally described, although it is not unlikely that they are the two sexes of a single species. If this should prove to be the case, then $C$. borealis Ewing (March, 1929) would have priority over C. onaga Jordan (September, 1929).

\section{Catallagia borealis Ewing \\ (Plate XXVIII, figs. 146, 147)}

1929 Catallagia borealis Ewing, Proc. Bio. Soc. Washington, 42:125.

Female. Preantennal region of the head with two oblique rows of bristles; the upper row consisting of five or six bristles, the lower row of four, with the second from the antenna the smallest. Postantennal region with three rows of four to six bristles each (Plate XXVIII, fig. 146). Pronotum armed with a single row of bristles. Meso- and metanotum each armed with three or four irregular rows of bristles. Each abdominal tergite armed with two rows of bristles; the anterior tergites further armed with one to three stout dorsal teeth on a side. Three antepygidial bristles present on a side, of which the middle is the longest. Sternite VII divided by a deep sinus into two lobes, of which the upper is more sharply defined than the lower (Plate XXVIII, fig. 147). Unfortunately, the receptaculum seminis has been destroyed in the single specimen known.

Male. Undescribed.

EAstern host. Meadow-mouse (Microtus pennsylvanicus pennsylvanicus (Ord)).

EAstern locality. Maine.

Type material. Female holotype from Microtus pennsyl- 
vanicus pennsylvanicus (Ord) at Basin Pond, Mount Katahdin. Maine, in the United States National Museum.

\section{Catallagia onaga Jordan}

(Plate XXVIII, fig. 145)

1929 Catallagia onaga Jordan, Nov. Zool., 35:172. fig. 7.

1933 Catallagia onaga Stewart, Jour. New York Ent. Soc., 41:255.

Male. Chaetotaxy of the head and general structure essentially as in $C$. borealis. Modified Segments: Process of the clasper large and broad, the outer margins with a number of slender setae. Manubrium long, expanded distad and turned up. Movable finger large, the upper portion produced over the process of the clasper into a broad triangular "nose"; the posterior margin armed with numerous slender setae. Penis broad and bladelike, ending in a short process; spring not completing a turn. For further details concerning the structure of the male genitalia, see Plate XXVIII, fig. 145.

FEMALE. Undescribed.

The above description and the accompanying illustration are based upon a single specimen from "Blarina brevicauda" at Adirondack Lodge, Essex County, New York, loaned through the courtesy of Dr. Karl Jordan.

EASTERn host. Short-tailed Shrew ("Blarina brevicauda"). EASTERn LOCALITY. New York.

Type material. Two males from "Blarina brevicauda" at New York in the N. C. Rothschild Collection (British Museum). 


\section{FAMILY ISCHNOPSYLLIDAE WAHLGREN}

1907 Ischnopsyllidae Wahigren, Ent. Ttdsk.. 23: 89.

1905 Ceratopsyllidae Baker, Proc. United Siates Nat. Mus., 29: 124.

1909 Ischnopsyllidae Oudemans, Nov. Zool., 16:155.

1915 Ischnopsyllidae Rothschild, Ent. Mo. Mag., 51:84.

1926 Ischnopsyllidae Dampf, Ent. Mitt., 15:385.

1929 Ischnopsyllidae Ewing, Manual External Parasites, p. 176.

1936 Ischnopsyllidae Wagner, Tierwelt Mitteleuropas, Bd. 6, Abt. 17, s. 17.

The American members of this family may be readily distinguished from other species of fleas by the presence of a pair of highly sclerotized preoral plates on each side of the head. These flaps, which vary in size and shape, represent modified genal ctenidial spines. Some of the genera are further characterized by one to several abdominal combs, which consist of either long teeth (true ctenidia) or thickened dorsal bristles (false combs). In the eastern genera the eyes are rudimentary or absent. The fifth tarsal joint of each leg is armed with four pairs of lateral plantar bristles and a basal submedian pair. In addition, the fifth tarsal joint may bear an apical pair of small bristles. So far as is known, all the members of this family are normally parasitic on bats, occurring only accidentally on other mammals. In the East but three genera have been found, and these may be separated by the following key:

\section{Key to the Genera of Eastern Ischnopsyllidae}

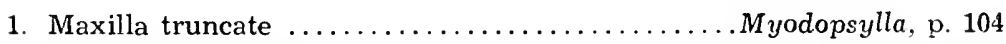

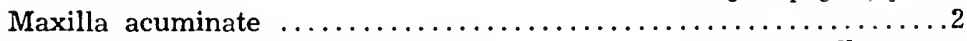

2. Abdomen with a comb on tergite VII .......... Eptescopsylla, p. 107

Abdomen without a comb on tergite VII .......... Sternopsylla. p. 108

\section{MYODOPSYLLA JORDAN AND ROTHSCHILD}

Myodopsylla Jordan and Rothschild, 1911, Nov. Zool., 18:88.

Genotype: Ceratopsylla insignis Rothschild

Maxilla truncate. Gena with a long stout bristle at the anterior border of the antennal groove near the vestigial eye. Pronotum with a true ctenidium consisting of long slender spines. Metanotum and abdominal tergites I to VII with a false 
ctenidium formed by the thickening of the dorsal bristles. One antepygidial bristle present on a side.

This genus is represented in the East by a single species, which is our commonest bat flea.

\section{Myodopsylla insignis (Rothschild)}

(Plate XXIX)

1903 Ceratopsylla insignis Rothschild, Nov. Zool., 10:319, Pl. 9, figs. 8-12. 1919 Myodopeylla subulata Chapin, Bull. Brooklyn Ent. Soc., 14:55.

1921 Myodopsylla insignis Jordan and Rothschild, Ectoparasites, 1:151, figs. 129, 130.

1928 Myodopsylla insignis Stewart, Cornell Univ. Agric. Exp. Sta.. Mem. 101, p. 869.

1928 Myodopsylla insignis Jordan, Nov. Zool., 34:188.

1929 Myodopsylla insignis Jordan, Nov. Zool., 35:177.

1933 Myodopsylla insignis Stewart, Jour. New York Ent. Soc., 41:253.

1937 Myodopsylla insignis Jordan, Nov. Zool., 40: 285.

Female. Frons with a wide clear area taking up most of the anterior region of the head. Dorsal region of this clear area with three unequal bristles. A series of four or five stout bristles near the anterior border of the antennal groove; gena with a number of small setae. Spines of the genal ctenidium broad, the posterior somewhat wider and extending more distad than the anterior. Genal process pointed. Labial palpus short, reaching to about one-fifth the length of the fore coxa. First segment of the antenna with about five small setae apically; second antennal segment with about five short bristles. Along the posterior edge of the antennal groove is a series of about eleven small setae. Postantennal bristles arranged in four rows; first row with two bristles, second and third with about five each, fourth or marginal row with about six. Pronotum with a ctenidium consisting of eighteen to twenty-one spines on a side. Each segment of the thorax armed with three irregular rows of bristles. Sternite VII without a sinus. Head of the receptaculum seminis about as wide as long, rounded dorsally. For further details concerning the structure of the female genitalia, see Plate XXIX, fig. 151.

Male. Chaetotaxy of the head slightly different from that of the female, the postantennal bristles being less regularly arranged (Plate XXIX, fig. 152). Modified SEGments: Clasper forming a lobe whose apex bears five to seven bristles. Movable finger more or less trapezoidal in shape with a corner produced into a terminally rounded process which bears a number of small setae (Plate XXIX, fig. 156). Paramere of the penis 
forked, the upper process more or less in the form of pincers, the lower process dilated apically and roughly in the form of a hook (Plate XXIX, fig. 155). Penis broad and bladelike, its spring long, completing at least one turn (Plate XXIX, fig. 153) . Sternite IX with a narrow ventral process which bears a stout bristle; apically the sternite bears another much more robust bristle (Plate XXIX, fig. 154).

RECORDS. CONNECTICUT-Hamden, September, 1915, on Myotis subulatus subulatus (Say), two females, male (E. A. Chapin). DISTRICT OF COLUMBIA-Washington, August, 1924, on "bat," female (P. Bartsch). ILLINOIS-Chicago, July 31, 1936, on "Myotis lucifugus," two females (R. Komarek). IOWA-Dubuque, March 19, 1938, on Myotis lucifugus lucifugus (LeConte), four females (T. Scott). KENTUCKY-Mammoth Cave, July 30, 1929, on "bat," male; August 6, 1929, on "Neotoma species," three females (L. Giovannoli); Colossal Cave, November, 1929, on "Myotis lucifugus." female (V. Bailey). MAINE-Mount Katahdin, September 7, 1928, on Myotis lucifugus lucifugus (LeConte), female (Harper and Hamilton). MARYLAND - Baltimore, June 20, 1922, on "Myotis lucifugus." male and female (F. M. Root) ; Plummer Island, August 1, 1923, on "bat," three males, two females. OHIO-Put-in-Bay, August 18, 1937, on "Myotis species," male (C. O. Mohr).

EASTERN HOSTS. Little Brown Bat (Myotis lucifugus lucifugus (LeConte) and Myotis subulatus subulatus (Say)), Wood Rat ("Neotoma species").

Eastern localities. Connecticut, District of Columbia, Illinois, Iowa, Kentucky, Maine, Maryland, Massachusetts, New York, Pennsylvania, Vermont, (Canada).

Type material. Three males and nine females from Waterloo, Ontario, Canada, on Myotis lucifugus (LeConte) in the N. C. Rothschild Collection (British Museum).

A species of bat flea from Missouri was described by Baker (1905, p. 137) under the name of Ceratopsylla crosbyi which apparently belongs in this genus. The description of this species is very inadequate and applies just as well to $M$. insignis (Rothschild). Its status has already been questioned by Rothschild (1906, p. 187) who doubts that it is distinct. At the present state of our knowledge, it is not possible to determine the status of this name either as representing a good species or as a synonym of $M$. insignis. 


\section{EPTESCOPSYLLA, NEW GENUS}

Maxilla acuminate. Ocular bristle absent. Remains of the vestigial eyes distinct, more or less oval. In addition to the genal ctenidium, two other combs are present, the pronotal ctenidium consisting of long slender spines, and a false comb on the seventh abdominal tergite consisting of thickened dorsal bristles. Metanotum and abdominal tergites I to III with two or three short, stout teeth on a side. Antepygidial bristles absent.

Genotype: Nycteridopsylla chapini Jordan

This genus is most closely allied to Nycteridopsylla Oudemans, from which it differs by the absence of false ctenidia on the anterior abdominal tergites (I to III). It may be readily separated from the other eastern genera by the absence of an ocular bristle. It is represented in the East by a single species.

\section{Eptescopsylla chapini (Jordan)}

(Plate XXX)

1929 Nycteridopsylla chapini Jordan, Nov. Zool., 35:39, PI. II, figs. 30, 31.

MaLE. Preantennal region of the head with six bristles, two of which are located near the genal spines, two near the antennal groove, and two in the middle region of the frons. Spines of the genal ctenidium oblique, the posterior almost twice as long as the anterior. Genal process not heavily sclerotized, rounded behind. Labial palpus about one-half as long as the anterior coxa. First segment of the antenna with four or five small setae; second antennal segment with four or five long bristles. Postantennal region with three rows of irregularly arranged bristles (Plate XXX, fig. 160). Pronotum with a single row of bristles and a ctenidium of about fifteen pointed spines on a side. Meso- and metathorax richly supplied with more or less irregularly arranged bristles. False comb of abdominal tergite VII consisting of eight or nine robust bristles on a side. Modified SEGMENTs: Clasper divided into two wellseparated processes, of which the dorsal is somewhat longer than the ventral. Dorsal process with a long bristle arising medially near the base; ventral process with a long, stout bristle situated apically. Movable finger bifurcate, dorsal branch curved, truncate, and without long bristles, ventral branch much longer and wider, with a fringe of five or six long bristles 
apically. Sternite IX elbowed, the posterior process long and lobular. Penis broad and bladelike, its spring long. For further details concerning the structure of the male genitalia, see Plate XXX, fig. 157.

Female. Frons with a series of four to six thickened, almost spinifrom bristles along the dorsal margin to the antennal groove. A longer bristle located below this series, and two more situated near the dorsal margin above the genal spines (Plate XXX, fig. 159). Sternite VII rounded, without a deep sinus. Head of the receptaculum seminis more or less oval in outline, about three-fourths as wide as long. For further details concerning the structure of the female genitalia, see Plate XXX, figs. 158, 161.

RECords. KENTUCKY-Colossal Cave, November 17, 1929 , on "Myotis sodalis," male, five females (V. Bailey). MARYLAND-Glen Echo, March 31, 1916, on "Eptesicus fuscus," male and female (R. C. Shannon).

Eastern hosts. Big Brown Bat ("Eptesicus fuscus"), Little Brown Bat ("Myotis sodalis").

EASTERn localities. Maryland, Kentucky.

Type material. Male and female from Glen Echo, Maryland, on Eptesicus fuscus (Beauvois) in the United States National Museum.

\section{STERNOPSYLLA JORDAN AND ROTHSCHILD}

Sternopsylla Jordan and Rothschild, 1921, Ectoparasites, 1:158.

Genotype: Ischnopsyllus texanus C. Fox

Miaxilla acuminate. Remains of the eye large and oval. Ocular bristle large and conspicuous. Pronotum with a true ctenidium consisting of long, slender spines. Meso- and metasternum each with a bristle anteriorly above the ventral angle. One long antepygidial bristle situated on a conical protuberance on each side. First segment of the middle and hind tarsus with numerous hairlike setae, particularly in the male.

This genus is represented in the East by a single species which occurs in the southern part of the United States.

\section{Sternopsylla texana (C. Fox) \\ (Plate XXXI)}

1914 Ischnopsyllus texanus C. Fox, United States Public Health Ser. Hyg. Lab., Bull. 97:16, Pl. V, figs. 6-8.

1921 Sternopsylla texanus Jordan and Rothschild, Ectoparasites, 1:158. 
Female. Preantennal region of the head with a conspicuous row of bristles on the frons extending from the base of the genal spines to the antennal groove. Bristles of this row of various sizes, there being two long ones near the antennal groove, three of the middle size, and six very small ones. One large bristle below this row and near the antennal groove; another situated above the second genal spine. Ocular bristle situated above the eye near the second antennal segment. Spines of the genal ctenidium long, pointed, slightly recurved, the posterior much longer than the anterior. Labial palpus five-segmented, very short. Postantennal region of the head with two irregular rows of about fourteen small setae near the posterior margin of the antennal groove, and four or five rows of long bristles irregularly arranged. Particularly outstanding are three long bristles which form a diagonal across the postantennal region of the head. Pronotum armed with two or three irregular rows of bristles and a ctenidium of twelve or thirteen long spines. Meso- and metanotum each with four or five irregular rows of bristles. Each abdominal tergite armed with two or three irregular rows of bristles. In addition. the anterior abdominal tergites armed with one stout dorsal tooth on a side. Margin of sternite VII more or less rounded, without a deep sinus. Head of the receptaculum seminis oval, half again as long as wide. For further details concerning the structure of the female genitalia, see Plate XXXI, figs. 162, 166.

MALE. Chaetotaxy of the head essentially as in the female (Plate XXXI, fig. 165). Hairlike setae on the first tarsal segment of the hind legs much longer and more numerous than in the female. Posterior end of the abdomen armed with four large bristles situated on conical protuberances (Plate XXXI, fig. 163). Sternite IX with a ventral process which is armed with a stout spiniform bristle. Clasper markedly incurved dorsally. Manubrium finger-like. Movable finger somewhat in the shape of a hammer, its posterior margin armed with several bristles. Penis broad and blunt; spring not completing a single turn (Plate XXXI, fig. 164).

RECORDS. FLORIDA-Gainesville, April 25, 1929, on "Myotis austroriparius" (=M. lucifugus (LeConte)), female (H. B. Sherman); Leon County, August 27, 1934, on "free-tailed bat," female (E. V. Komarek); Tallahassee, May 23, 1936, on Tadarida cynocephala (LeConte), male and female (E. V. Komarek). GEORGIA-Thomasville, June 26, 1936, on "freetailed bat." male and female. 
Eastern Hosts. Little Brown Bat (Myotis lucifugus lucifugus (LeConte)), Free-tailed Bat (Tadarida cynocephala (LeConte)) .

Eastern localities. Georgia, Florida.

Type material. Female holotype from Pecos, Texas, on "Nyctinomus mexicanus" not located. Male allotype from Thomasville, Georgia, (described above) in the United States National Museum.

\section{SPECIES OF POSSIBLE OCCURRENCE Ceratophyllus acutus Baker}

1928 Ceratophyllus acutus Stewart, Cornell Univ. Agric. Exp. Sta., Mem. 101, p. 869.

1929 Ceratophyllus acutus Jordan, Nov. Zool, 35:175.

The occurrence of this species in New York, as originally reported, has been seriously questioned by Jordan. The above name is regarded as a synonym of Diamanus montanus (Baker).

\section{Peromyscopsylla selenis (Rothschild)}

1933 Ctenopsyllus selenis Stewart, Jour. New York Ent. Soc., 41: 259.

The record of the occurrence of this species in New York was apparently based upon the misidentification of a specimen in the United States National Museum belonging to P. hesperomys (Baker).

\section{Myodopsylla crosbyi (Baker)}

1905 Ceratopsyllus crosbyi Baker, Proc. United States Nat. Mus., 29:137. 1906 Ceratopsyllus crosbyi Rothschild, Nov. Zool., 13:187.

The status of this species has already been discussed on p. 106. 


\section{SYNONYMIC INDEX}

Argopsylla gallinacea

Ceratophyllidae

Ceratophyllus acasti

Ceratophyllus acerbus

Ceratophyllus arctomys

Ceratophyllus asio

Ceratophyllus bruneri

Ceratophyllus caedens

Ceratophyllus canadensis

Ceratophyllus fasciatus

Ceratophyllus ignotus

Ceratophyllus leucopus

Ceratophyllus multispinosus

Ceratophyllus oculatus

Ceratophyllus peromysci

Ceratophyllus pseudarctomys

Ceratophyllus quirini

Ceratophyllus rileyi

Ceratophyllus sexdentatus

Ceratophyllus vison

Ceratophyllus wagneri

Ceratophyllus wickhami

Ceratopsylla insignis

Ceratopsyllidae

Ctenocephalus canis

Ctenocephalus felis

Ctenocephalus simplex

Ctenophthalmus fraternus

Ctenophthalmus genalis

Ctenophthalmus gigas

Ctenophthalmus musculi

Ctenophthalmus wenmanni

Ctenopsylla genalis

Ctenopsyllidae

Ctenopsyllus catatina

Ctenopsyllus hesperomys
$=$ Echidnophaga gallinacea (Westwood)

$=$ Dolichopsyllidae Baker

= Opisodasys pseudarctomys (Baker)

$=$ Megabothris acerbus (Jordan)

$=$ Oropsylla arctomys (Baker)

= Megabothris asio (Baker)

$=$ Opisocrostis bruneri (Baker)

$=$ Orchopeas caedens (Jordan)

$=$ Nosopsyllus fasciatus (Bosc)

$=$ Nosopsyllus fasciatus (Bosc)

$=$ Foxella ignotus (Baker)

$=$ Orchopeas leucopus (Baker)

= Odontopsyllus multispinosus (Baker)

$=$ Nosopsyllus fasciatus (Bosc)

$=$ Megabothris wagneri (Baker)

= Opisodasys pseudarctomys (Baker)

$=$ Megabothris quirini (Rothschild)

$=$ Ceratophyllus diffinis Jordan

$=$ Orchopeas sexdentatus (Baker)

$=$ Megabothris vison (Baker)

$=$ Megabothris wagneri (Baker)

= Orchopeas wickhami (Baker)

$=$ Myodopsyllus insignis (Rothschild)

$=$ Ischnopsyllidae Wahlgren

$=$ Ctenocephalides canis (Curtis)

= Ctenocephalides felis (Bouché)

= Cediopsylla simplex (Baker)

$=$ Rectofrontia fraterna (Baker)

= Nearctopsylla genalis (Baker)

$=$ Tamiophila grandis (Rothschild)

$=$ Ctenopsyllus segnis (Schönherr)

= Epitedia wenmanni (Rothschild)

$=$ Nearctopsylla genalis (Baker)

$=$ Hystrichopsyllidae

= Peromyscopsylla catatina (Jordan)

$=$ Peromyscopsylla hesperomys (Baker) 
Ctenopsyllus hygini

Ctenopsyllus mexicanus

Ctenopsyllus musculi

Ctenopsyllus selenis

Hoplopsyllus glacialis lynx

Hystrichopsylla americana

Ischnopsyllus texanus

Leptopsylla catatina

Leptopsylla hesperomys

Leptopsylla musculi

Leptopsylla segnis

Leptopsyllidae

Loemopsylla cheopis

Monopsyllus vison

Monopsyllus wagneri

Myodopsylla subulata

Myoxopsylla leucopus

Myoxopsylla pseudarctomys

Myoxopsylla wickhami

Neopsylla faceta

Neopsylla grandis

Neopsylla similis

Neopsylla striata

Neopsylla testor

Neopsylla wenmanni

Nycteridopsylla chapini

Oropsylla bruneri

Peromyscopsylla spinifrons

Pulex affinis

Pulex avium

Pulex bruneri

Pulex canis

Pulex cheopis

Pulex fasciatus

Pulex felis

Pulex gallinae

Pulex gigas Baker

Pulex gigas Kirby

Pulex gillettei

Pulex howardi

Pulex ignotus

Pulex inaequalis var. simplex
$=$ Nearctopsylla genalis (Baker)

$=$ Ctenopsyllus segnis (Schönherr)

$=$ Ctenopsyllus segnis (Schönherr)

$=$ Peromyscopsylla selenis (Rothschild)

$=$ Hoplopsyllus lynx (Baker)

= Stenoponia americana (Baker)

$=$ Sternopsylla texana (C. Fox)

= Peromyscopsylla catatina (Jordan)

$=$ Peromyscopsylla hesperomys (Baker)

$=$ Ctenopsyllus segnis (Schönherr)

$=$ Ctenopsyllus segnis (Schönherr)

$=$ Hystrichopsyllidae Tiraboschi

= Xenopsylla cheopis (Rothschild)

$=$ Megabothris vison (Baker)

$=$ Megabothris wagneri (Baker)

$=$ Myodopsylla insignis (Rothschild)

$=$ Orchopeas leucopus (Baker)

$=$ Opisodasys pseudarctomys (Baker)

= Orchopeas wickhami (Baker)

$=$ Epitedia faceta (Rothschild)

$=$ Tamiophila grandis (Rothschild)

= Epitedia wenmanni (Rothschild)

$=$ Tamiophila grandis (Rothschild)

$=$ Epitedia testor (Rothschild)

$=$ Epitedia wenmanni (Rothschild)

= Eptescopsylla chapini (Jordan)

$=$ Opisocrostis bruneri (Baker)

$=$ Peromyscopsylla hesperomys (Baker)

$=$ Hoplopsyllus affinis (Baker)

$=$ Ceratophyllus gallinae Schrank

$=$ Opisocrostis bruneri (Baker)

$=$ Ctenocephalides canis (Curtis)

= Xenopsylla cheopis (Rothschild)

$=$ Nosopsyllus fasciatus (Bosc)

= Ctenocephalides felis (Bouché)

$=$ Ceratophyllus gallinae Schrank

$=$ Tamiophila grandis (Rothschild)

$=$ Hystrichopsylla gigas (Kirby)

= Orchopeas wickhami (Baker)

= Orchopeas wickhami (Baker)

= Foxella ignotus (Baker)

$=$ Cediopsylla simplex (Baker) 
Pulex lynx

Pulex multispinosus

Pulex musculi

Pulex pallulorum

Pulex penetrans

Pulex segnis

Pulex serraticeps

Pulex wickhami

Rhadinopsylla fraterna

Rhynchoprionidae

Sarcopsyllidae

Sarcopsyllus gallinaceus

Spilopsyllus cuniculi Schwartz and Shook

Spilopsyllus simplex

Stenoponia wetmorei

Typhlopsylla american $x$

Typhlopsylla assimilis

Typhlopsylla fraterna

Typhlopsylla grandis

Typhlopsylla mexicana

Typhlopsylla musculi

Xestopsylla gallinacea
$=$ Hoplopsyllus lynx (Baker)

$=$ Odontopsyllus multispinosus (Baker)

$=$ Ctenopsyllus segnis (Schönherr)

= Echidnophaga gallinacea (Westwood)

= Tunga penetrans (Linnaeus)

$=$ Ctenopsyllus segnis (Schönherr)

$=$ Ctenocephalides canis (Curtis)

= Orchopeas wickhami (Baker)

$=$ Rectofrontia fraterna (Baker)

$=$ Hectopsyllidae Baker

$=$ Hectopsyllidae Baker

= Echidnophaga gallinacea (Westwood)

$=$ Cediopsylla simplex (Baker)

= Cediopsylla simplex (Baker)

= Sterıoponia americana (Baker)

= Foxella ignotus (Baker)

$=$ Ctenophthalmus pseudagyrtes Baker

$=$ Rectofrontia fraterna (Baker)

= Tamiophila grandis (Rothschild)

$=$ Ctenopsyllus segnis (Schönherr)

= Ctenopsyllus segnis (Schönherr)

= Echidnophaga gallinacea (Westwood) 


\title{
HOST INDEX
}

\author{
CLASS MAMMALIA
}

Order Marsupialia

\author{
Virginia Opossum, Didelphis

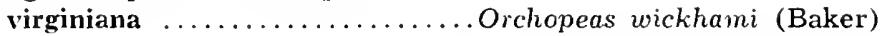 \\ Ctenocephalides felis (Bouché) \\ Oropsylla arctomys (Baker) \\ Orchopeas leucopus (Baker) \\ Peromyscopsylla catatina (Jordan) \\ Rhopalopsyllus gwyni C. Fox \\ Pulex irritans Linnaeus
}

\section{Order Insectivora}

Short-tailed Shrew, Blarina

brevicauda

Ctenophthalmus pseudagyrtes Baker Doratopsylla blarinae C. Fox

Doratopsylla curvata. Rothschild

Cediopsylla simplex (Baker)

Odontopsylius multispinosus (Baker)

Orchopeas leucopus (Baker)

Orchopeas wickhami (Baker)

Epitedia wenmanni (Rothschild)

Atyphloceras bishopi (Jordan)

Catallagia onaga Jordan

Peromyscopsylla catatina. (Jordan)

Hystrichopsylla gigas tahavuana

Jordan

Star-nosed Mole. Condylura

Nearctopsylla genalis (Baker)

cristata

Ctenophthalmus pseudagyrtes Baker Orchopeas wickhami (Baker)

Water Shrew, Neosorex albibarbis..Doratopsylla blarinae C. Fox

Hairy-tailed Mole, Parascalops

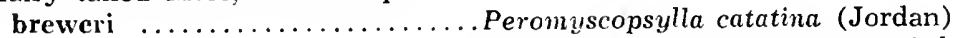

Ctenophthalmus pseudagyrtes Baker

Epitedia wenmanni (Rothschild)

Mole, Scalops aquaticus Ctenophthalmus pseudagyrtes Baker

Nearctopsylla genalis (Baker)

Foxella ignotns (Baker)

\section{Order Chiroptera}

Big Brown Bat, Eptesicus fuscus ...Eptescopsylla chapini (Jordan)

Little Brown Bat. Myotis lucifugus.. Myodopsylla insignis (Rothschild)

Stemopsinlla texana (C. Fox) 
Free-tailed Bat, Tadarida

cynocephala Sternopsylla texana (C. Fox)

\section{Order Carnivora}

Dog, Canis familiaris

Ctenocephalides canis (Curtis)

Ctenocephalides felis (Bouché)

Echidnophaga gallinacea (Westwood)

Pulex irritans Linnaeus

Cediopsylla simplex (Baker)

Orchopeas wickhami (Baker)

Coyote, Canis Iatrans

Echidnophaga gallinacea (Westwood)

Cediopsylla simplex (Baker)

Cat, Felis domestica

Ctenocephalides canis (Curtis)

Ctenocephalides felis (Bouché)

Echidnophaga gallinacea (Westwood)

Pulex irritans Linnaeus

Cediopsylla simplex (Baker)

Canada Lynx, Lynx canadensis ....Hoplopsyllus lynx (Baker)

Wildcat, Lynx rufus .............. Orchopeas wickhami (Baker)

Cediopsyilla simplex (Baker)

Odontopsyllus multispinosus (Baker)

Skunk, Mephitis nigra, etc. ........ Oropsylla arctomys (Baker)

Skunk, Mephitis elongata,

Cediopsylla simplex (Baker)

Spilogale ambarvalis, etc. ......Echidnophaga gallinacea (Westwood)

Weasel, Mustela noveboracensis,

Ctenocephalides jelis (Bouché)

etc.

Megabothris vison (Baker)

Nosopsyllus fasciatus (Bose)

Orchopeas wickhami (Baker)

Epitedia wenmanni (Rothschild)

Tamiophila grandis (Rothschild)

Nearctopsylla genalis (Baker)

Ctenophthalmus pseudagyrtes Baker

Mink, Mustela vison ...........Megabothris vison (Baker)

Orchopeas wickhami (Baker)

Nosopsyllus fasciatus (Bosc)

Nearctopsylla genalis (Baker)

Raccoon, Procyon lotor ..........Trichopsylla lotoris Stewart

Orchopeas wickhami (Baker)

Olontopsyllus multispinosus (Baker)

Cediopsylla simplex (Baker)

Clenccephalides felis (Bouché)

Badger, Taxidea taxus ........... Oropsylla arctomys (Baker)

Gray Fox, Urocyon

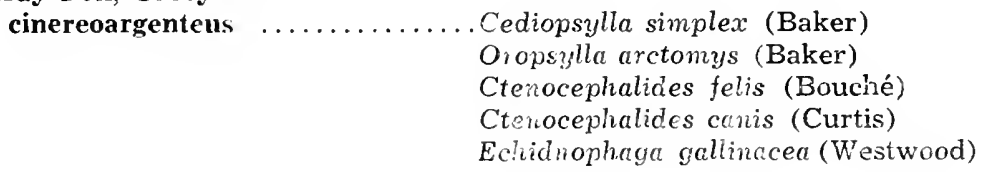


Red Fox, Vulpes regalis, V. fulva. etc. .Ctenocephalides canis (Curtis) Hoplopsyllus affinis (Baker)

Pulex irritans Linnaeus

Cediopsylla simplex (Baker)

Oropsylla arctomys (Baker)

Megabothris wagneri (Baker)

Echiduophaga gallinacea (Westwood)

Epitedia wenmanni (Rothschild) (in scat)

\section{Order Rodentia}

Ground Squirrel, Citellus

tridecimlineatus, C. franklini,

etc. ...................... Opisocrostis bruneri (Baker)

Epitedia wenmanni (Rothschild)

Ctenophthalmus pseudagyrtes Baker

Red-backed Mouse, Evotomys

gapperi..$\ldots \ldots \ldots \ldots \ldots$. Ctenophthalmus pseudagyrtes Baker

Stenoponia americana (Baker)

Peromyscopsylla catatina (Jordan)

Epitedia wenmanni (Rothschild)

Pocket Gopher, Geomys bursarius..Foxella ignotus (Baker)

Nearctopsylla genalis (Baker)

Ctenophthalmus pseudagyrtes Baker

Flying Squirrel, Glaucomys volans.Orchopeas wickhami (Baker)

Epitedia wenmanni (Rothschild)

Orchopeas caedens (Jordan)

Megabothris wagneri (Baker)

Megabothris quirini (Rothschild)

Opisocrostis bruneri (Baker)

Conorhinopsylla stanfordi Stewart

Opisodasys pseudarctomys (Baker)

Ctenophthalmus pseudagyrtes Baker

Ctenocephalides felis (Bouché)

Woodchuck, Marmota monax ...... Oropsylla arctomys (Baker)

Opisodasys pseudarctomys (Baker)

Orchopeas wickhami (Baker)

Ctenocephalides canis (Curtis)

Meadow-mouse, Microtus

pennsylvanicus, etc. ..........Megabothris asio (Baker)

Epitedia wenmanni (Rothschild)

Orchopeas leucopus (Baker)

Atyphloceras bishopi Jordan

Ctenophthalmus pseudagyrtes Baker

Peromyscopsylla catatina (Jordan)

Hystrichopsylla gigas tahavuana

Jordan

Catallagia borealis Ewing

Stenoponia anericana (Baker)

Doratopsylla blarinae C. Fox

Rectofrontia fraterna (Baker) 


House-mouse, Mus musculus $\ldots$. Xenopsylla cheopis (Rothschild)
Ctenopsyllus segnis (Schönherr)
Ctenophthalmus pseudagyrtes Baker
Doratopsylla blarinae C. Fox
Orchopeas wickhami (Baker)
Orchopeas leucopas (Baker)

Wood-rat, Neotoma

pennsylvanica, etc. ............ Orchopeas sexdentatus (Baker)

Epitedia wenmanni (Rothschild)

Ctenophthalmus pseudagyrtes Baker

Nosopsyllus fasciatus (Bosc)

Myodopsylla insignis (Rothschild)

Muskrat, Ondatra zibethica .......Ctenophthalmus pseudagyrtes Baker

Rice-rat, Oryzomys palustris ...... Rhopalopsyllus gwyni C. Fox

White-footed Mouse, Peromyscus

leucopus, etc. ............... Epitedia wenmanni (Rothschild)

Hoplopsyllus affinis (Baker)

Stenoponia americana (Baker)

Orchopeas leucopus (Baker)

Peromyscopsylla hesperomys

(Baker)

Peromyscopsylla scotti I. Fox

Hystrichopsylla gigas tahavuana

Jordan

Orchopeas wickhami (Baker)

Ctenophthalmus pseudagyrtes Baker

Nosopsyllus fasciatus (Bosc)

Doratopsylla blarinae C. Fox

Ctenopsyllus segnis (Schönherr)

Pine-mouse, Pitymys pinetorum ...Ctenophthalmus pseudagyrtes Baker House-rat, Rattus norvegicus ..... Nosopsyllus fasciatus (Bosc)

Xenopsylla cheopis (Rothschild)

Hoplopsyllus affinis (Baker)

Ctenocephalides canis (Curtis)

Ctenocephalides felis (Bouché)

Ctenophthalmus pseudagyrtes Baker

Ctenopsyllus segnis (Schönherr)

Echidnophaga gallinacea (Westwood)

Stenoponia americana (Baker)

Epitedia wenmanni (Rothschild)

Roof-rat, Ratlus r. alexandrinus ...Ctenopsyllus segnis (Schönherr)

Xenopsylia cheopis (Rothschild)

Orchopeas wickhami (Baker)

Echidnophaga gallinacea (Westwood)

Black Rat, Rattus rattus

Ctenopsyllus segnis (Schönherr)

Orchopeas wickhami (Baker)

Cediopsylla simplex (Baker)

Xenopsylla cheopis (Rothschild) 
Gray Squirrel, Sciurus carolinensis. Orchopeas wickhami (Baker)

Stenoponia americana (Baker)

Opisocrostis bruneri (Baker)

Conorhinopsylla stanfordi Stewart

Pulex irritans Linnaeus

Echidnophaga gallinacea (Westwood)

Red Squirrel, Sciurus hudsonicus... Orchopeas wickhami (Baker)

Ctenocephalides felis (Bouché)

Megabothris vison (Baker)

Orchopeas caedens (Jordan

Conorhinopsylla stanfordi Stewart

Ctenophthalmus pseudagyrtes Baker

Epitedia faceta Rothschild

Oropsylla arctomys (Baker)

Tamiophila grandis (Rothschild)

Pulex irritans Linnaeus

Fox Squirrel, Sciurus niger ....... Orchopeas wickhami (Baker)

Cotton-rat, Sigmodon hispidus ....Rhopalopsylla grvyni C. Fox

Stenoponia americana (Baker)

Ctenopsyllus segnis (Schönherr)

Xenopsylla cheopis (Rothschild)

Chipmunk, Tamias striatus .......Megabothris acerbus (Jordan)

Ceratophyllus gallinae Schrank

Megabothris vison (Baker)

Orchopeas wickhami (Baker)

Ctenophthalmus pseudagyrtes Baker

Tamiophila grandis Rothschild

Jumping Mouse, Zapus hudsonicus. Stenoponia americana (Baker)

\section{Order Lagomorpha}

Cottontail, Sylvilagus floridanus ...Cediopsylla simplex (Baker)

Odontopsyllus multispinosus (Baker)

Hoplopsyllus affinis (Baker)

Orchopeas wickhami (Baker)

Pulex irritans Linnaeus

Ctenocephalides felis (Bouché)

Ctenocephalides canis (Curtis)

Xenopsylla cheopis (Rothschild)

Tamiophila grandis Rothschild

Ctenophthalmus pseudagyrtes Baker

Echidnophaga gallinacea (Westwood)

Jackrabbit, Lepus americanus, etc. . Pulex irritans Linnaeus

Hoplopsyllus affinis (Baker)

Hoplopsyllus lynx (Baker)

\section{Order Artiodactyla}

Horse, Equus caballus ..............chidnophaga gallinacea (Westwood)

White-tailed Deer, Odocoileus

virginianus .................. Oropsylla arctomys (Baker)

Hog, Sus scrofa .................. Pulex irritans Linnaeus 
Order Primates

Man. Homo sapiens ............. Ctenocephalides canis (Curtis)

Ctenocephalides felis (Bouché)

Pulex irritans Linnaeus

Ceratophyllus gallinae (Schrank)

Orchopeas wickhami (Baker)

Cediopsylla simplex (Baker)

Echidnophaga gallinacea

(Westwood)

Xenopsylla cheopis (Rothschild)

Hoplopsyllus affinis (Baker)

\section{CLASS AVES}

Ruffed Grouse, Bonassa umbellus .. Ceratophyllus diffinis Jordan Quail, Colinus virginianus ........Echidnophaga gallinacea (Westwood)

Domestic Turkey, Mellagris

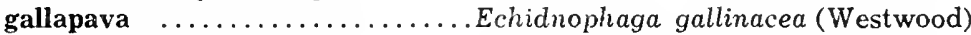

Common Hen, Gallus gallıs .......Ceratophyllus gallinae (Schrank) Echidnophaga gallinacea (Westwood)

Screech Owl, Otus asio ..........Ctenophthalmus pseudagyrtes Baker Orchopeas wickhami (Baker) Megabothris asio (Baker)

Barred Owl, Strix varia .......... Oropsylla arctomys (Baker)

Belted Kingfisher, Megaceryle

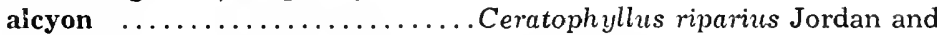
Rothschild

Tree Swallow, Iridoprocne bicolor.. Ceratophyllus idius Jordan and Rothschild

Ceratophyllus gallinae (Schrank)

Cliff Swallow, Petrochelidon

albifrons .................. Ceratophyllus celsus Jordan

Purple Martin, Progne subis ......Ceratophyllus idius Jordan and Rothschild

Bank Swallow, Riparia riparia ..... Ceratophyllus riparius Jordan and Rothschild

Blue Jay, Cyanocetta cristata ......Echidnophaga gallinacea (Westwood) Bluebird, Sialia sialis ...........Ceratophyllus idius Jordan and Rothschild

Ceratophyllus gallinae (Schrank)

Ceratophyllus niger C. Fox

Ceratophyllus diffinis Jordan

Starling, Sturnus vulgaris .........Epitedia wenmanni (Rothschild)

Catbird, Dumetella carolinensis ...Ceratophyllus diffinis Jordan

English Sparrow, Passer

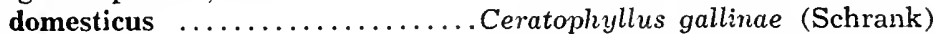

Echidnophaga gallinacea (Westwood)

Robin, Planesticus migratorius ..... Ceratophyllus diffinis Jordan

Ovenbird, Seiurus aurocapillus .... Ceratophyllus diffinis Jordan Veery, Hylocichla fuscescens ...... Ceratophyllus diffinis Jordan House-wren, Troglodytes aedon ...Ceratophyllus diffinis Jordan 


\section{SELECTED BIBLIOGRAPHY}

BAKer, CARL F.

1895. Preliminary studies in Siphonaptera. Canadian Entomologist, 27, pp. 19-22, 63-67, 108-112, 130-132, 162-164, 186-191, 221-222.

1898. Notes on Siphonaptera, with descriptions of four new species. Journal of the New York Entomological Society, 6:53-56.

1904. A revision of American Siphonaptera or fleas, together with a complete list and bibliography of the group. Proceedings of the United States National Museum, 27:365-463.

1905. The classification of the American Siphonaptera. Proceedings of the United States National Museum, 29:121-170.

Bishopp, F. C.

1931. Fleas and their control. United States Department of Agriculture, Farmers Bulletin 897, pp. 3-15.

1937. How to control fleas. United States Department of Agriculture, Leaflet No. 152, pp. 1-4.

Chapin, E. A.

1919. New species of North. American Siphonaptera. Bulletin of the Brooklyn Entomological Society, 14:49-62.

EwING, H. E.

1924. Notes on the taxonomy and natural relationship of fleas, with descriptions of four new species. Parasitology, 16:341-355.

1925. Notes on the siphonapteran genus Doratopsylla Jordan and Rothschild. Journal of Parasitology, 12:43-46.

1929a. Notes on the siphonapteran genus Catallagia Rothschild including the description of a new species. Proceedings of the Biological Society of Washington, 42:125-127.

1929b. Manual of external parasites, pp. 153-183.

1931. Some factors affecting the distribution of and variation in North American ectoparasites. American Naturalist, 65:360-369.

- and Irving Fox

1938. Occurrence of the oriental rat flea in the interior of the United States. Science, 88: 427 .

Fox, CARROLL

1914a. Some new Siphonaptera. United States Public Health Service Hygienic Laboratory, Bulletin No. 97, pp. 7-17. 
Fox, Carroll

1914b. The taxonomic value of the copulatory organs of fomales in the order Siphonaptera. United States Public Health Service Hygienic Laboratory, Bulletin No. 97, pp. 19-25.

1925a. A comparative study of rat flea data for several seaports of the United States. United States Public Health Service, Public Health Reports, 40: 1909-1934.

1925b. Insects and Disease of Man, pp. 112-142.

1931. A limited rat flea survey of Savannah, Georgia. United States

Public Health Service, Public Health Reports, 46:574.

Fox, Irving

1939. New species and a new genus of Nearctic Siphonaptera. Proceedings of the Entomological Society of Washington, 41:46-50.

Hasseltine, H. E.

1929. Rat flea survey of the Port of Norfolk, Virginia. United States

Public Health Service, Public Health Reports, 44:579-589.

ILLINGWORTH, J. F.

1915. Notes on the habits and control of the chicken flea (Echidnophaga gallinacea Westwood). Journal of Economic Entomology, 8:492-495. JORDAN, KARL

1925. New Siphonaptera, Novitiates Zoologicae, 32:96-112.

1926. On Xenopsylla and some allied genera of Siphonaptera. Verhandlungen des III Internationalen Entomologen-kongresses (1925), pp. 593-627.

1928. Siphonaptera collected during a visit to the eastern United States of North America in 1927. Novitates Zoologicae, 34: 178-188.

1929a. Notes on North American fleas. Novitates Zoologicae, 35:28-39.

1929b. Further records of North American bird fleas. Novitates Zoologicae, 35: 89-92.

1929c. On a small collection of Siphonaptera from the Adirondacks with a list of the species known from the state of New York. Novitates Zoologicae, 35:168-177.

1930. On some problems of distribution, variability, and variation in North American Siphonaptera. Transactions of IV International Congress of Entomology (1928), pp. 489-499.

1933a. Records of Siphonaptera from the state of New York. Novitates Zoologicae, 39:62-65.

1933b. A survey of the classification of the American species of Ceratophyllus s. lat. Novitates Zoologicae, 39:70-79. 
JORDAN, KARL

1937. On some North American Siphcnaptera. Novitates Zoologicae. 40: 262-271.

$\longrightarrow$, and N. Charles Rothschild

1915a. Contribution to our knowledge of American Siphonaptera.

Ectoparasites, 1: 45-60.

1920a. On the species and genera of Siphonaptera described by Kolenati.

Ectoparasites, 1:61-64.

$\ldots$, and —.

1921a. New genera and species of bat-fleas. Ectoparasites, 1:142-162. - - , and —.

$1921 \mathrm{~b}$. On Ceratophyllus fasciatus and some allied Indian species of

fleas. Ectoparasites, 1:178-198.

1923. On the genera Rhopalopsyllus and Parapsyllus. Ectoparasites. 1:320-370.

Lru, ChI-YiNG

1935. Two new bird Ceratophylli from Minnesota. Annals of the Entomological Society of America, 28:121-125.

OSBORN, Herbert

1896. Insects affecting domestic animals. United States Department of Agriculture, Division of Entomology, Bulletin No. 5, new series, pp. 141-155.

Oudemans, A. C.

1909. Neue Ansichten uber die Morphologie des Flohkopfes, sowie uber die Ontogenie, Phylogenie und Systematik der Flohe. Novitates Zoologicae, 16:133-158.

Packard, Alpheus S.

1895. On the systematic position of the Siphonaptera, with notes on their structure. Proceedings of the Boston Society of Natural History, 26:312-355.

RILEy, WM. A.

1936. The tropical or oriental rat flea, Xenopsylla cheopis, established in Minnesota. Journal-Lancet, 56:591-592.

Rothschild, N. Charles

1906. Notes on bat fleas. Novitates Zoologicae, 13:186-188.

1915a. Further notes on Siphonaptera Fracticipita, with descriptions of new genera and species. Ectoparasites, 1:25-29.

1915b. On Neopsylla and some allied genera of Siphonaptera. Ectoparasites, 1: $30-44$.

1921. The generic name of the sand-flea. Ectoparasites, 1:129-130.

RoudABUSH, R. L.

1939. Survival of the tropical rat flea in United States. Science, 89:79. 
Roudabush, R. L., and E. R. Becker

1934. The tropical rat flea in the interior of the United States. Science, 80:97.

Shaftesbury, ARchie D.

1934. The Siphonaptera (fleas) of North Carolina, with special reference to sex ratios. Journal of the Elisha Mitchell Scientific Society, 49: $247-263$

Sikes, Enid K.

1930. Larva of Ceratophyllus wickhami and other species of fleas. Parasitology, 22: 242-259.

Stewart, M. A.

1926. Two new Siphonaptera from New York. Insecutor Inscitiae Menstruus, 14:122-126.

1928a. In Leonard's A list of the insects of New York. Cornell University Agricultural Experiment Station, Memoir 101, pp. 1868-1869.

1928b. Two new Siphonaptera from Colorado. Canadian Entomologist, 60: 148-151.

1933. Revision of the list of Siphonaptera from New York State. Journal of the New York Entomological Society, 41:253-262.

Strnes, C. W., and B. J. Collins

1930. Ctenocephalides, new genus of fleas, type Pulex canis. United States Public Health Service, Public Health Reports, 45:1308-1310. WAGNER, JULIUS

1927a. Uber die Einteilung der Gattung Ceratophyllus Curtis. Konowia, 6:101-113.

1927b. Zur Benennung Ctenopsyllus Kolenati. Konowia, 6:287-290.

1929. Uber die nordamerikanische Ceratophylli welche auf Zieseln und Murmeltieren leben. Konowia, 8:311-315.

Williams, C. L.

1929. A rat and rat-flea survey of ships at the Port of New York. United States Public Health Service, Public Health Reports, 44: 443-476. 


\section{INDEX *}

acasti, 57.

acerbus, 67, 69.

acutus, 110.

aeger, 64.

affinis, 14, 116, 119.

ambulans, 9.

americana (Stenoponia), 81, 116.

americana (Typhlopsylla), 81 .

anomalus, 14.

Aphaniptera, 7.

arctomys, 45, 114, 115, 116, 119.

Argopsylla, 10.

asio, 67, 117.

assimilis, 34 .

Atyphloceras, 78, 80.

avium, 52.

Bibliography, 121.

bishopi, 80, 114.

bisoctodentatus, 34 .

Blarina brevicauda, 114.

blarinae, 92, 114.

Bonassa umbellus, 119.

borealis, 102, 117.

brooksi, 90.

bruneri, 43, 116.

caedens, 59, 62, 116.

canadensis, 74 .

canis, 24, 26, 115, 116, 119.

Canis familiaris, 115.

Canis latrans, 115.

Catallagia, 78, 102.

catatina, 84, 87, 114, 116.

Cediopsylla, 13, 21.

celsus, 49, 119.

Ceratophyllidae, 29.

Ceratophyllus, 30, 48.

Ceratopsyllus insignis, 105.

Ceratopsyllidae, 104.

chapini, 107, 115.

charlottensis, 102.

cheopis, 16, 118, 119.

chigoe, 12.

Citellus franklini, 116.

Citellus tridecimlineatus, 116 .

Colinus virginianus, 119.

Collection, 1.
Conorhinopsylla, 29, 41.

Condylura cristata, 114.

Control, 4.

Corrodopsylla, 94.

crosbyi, 106, 110.

Ctenocephalides, 13, 24.

Ctenocephalus, 24.

Ctenophthalmus, 29, 34.

Ctenopsyllidae, 77.

Ctenopsyllus, 78, 88.

cuniculi, 21.

curvata, 94, 114.

Cyanocetta cristata, 119.

dasycnemus, 92.

Didelphis virginianus, 114 .

diffinis, 50, 119, 120 .

Dolichopsyllidae, 7, 29.

Dolichopsyllinae, 29.

Doratopsylla, 78, 92.

Dumetella carolinensis, 120 .

durus, 62.

Echidnophaga, 9.

Epitedia, 18, 95.

Eptescopsylla, 104, 107.

Eptesicus fuscus, 115.

Equus caballus, 119.

Evotomys gapperi, 116.

faceta, 98 .

fasciatus, 73,115 .

felis, 24, 114, 115, 116, 119 .

Felis domestica, 115 .

floridensis, 32 .

Foxella, 29, 39.

Fracticipita, 7, 8.

fraterna, 38, 117 .

gallinacea, 10, 115, 116, 118, 119.

gallinae, 52, 119.

Gallus gallus, 119.

genalis, 91, 114, 115, 116.

Geomys bursarius, 116.

gigas (Baker), 100.

gillettei, 59 .

glacialis, 15.

Glaucomys volans, 116.

* Synonyms are in italics. 
grandis, 100, 115.

gwyni, 30, 114.

Hectopsyllidae, $7,9$.

hesperomys, 84, 117.

hirsutus, 42.

hirundinus, 48.

Homo sapiens, 119.

homoeus. 32.

Hoplopsyllus, 13, 14.

Host Index, 114.

howardii, 59.

hygini, 91.

Hylocichla fuscescens, 120.

Hystrichopsylla, 78.

Hystrichopsyllidae, 8, 77.

Hystrichopsyllinae, 77 .

idius, 51, 119.

ignotus, 59, 114, 116.

incequalis var. s:mplcx, 21.

insignis, 104, 115.

Integricipita, 7.

Iridoprocne bicolor, 119.

irritans, 19, 114, 115, 116, 119.

Ischnopsyllidae, 8, 104.

Ischnopsyllus texamus,

jigger, 12.

Leptopsylla $=$ Ctenopsyllus, 77.

Leptopsyllidae, 77.

Lepus americanus, 119.

leucopus, 64, 114.

Life History, 4.

Loemopsylla $=$ Xenopsylla, 16.

lotoris, 32, 33, 115.

lucidus, 72.

lutzii, 30 .

lynx, 14, 15, 115, 119.

Lynx canadensis, 115.

Lynx rufus, 115.

Marmota monax, 116.

Megabothris, 30,67 .

Megaceryle alcyon, 119.

Mellagris gallapava, 119.

Mephitis elongata, 115.

Mephitis nigra, 115.

ne.ricuna, 89.

Microtus pennsylvanicus. 117.

Morphology, 2.

multidentatus, 80.

multispinosus, 47, 114, 115.

musculi, 88.

Mus musculus, 117.

Mustela noveboraccnsis, 115.

Mustela vison, 115.
Myodopsylla, 104.

Myotis lucifugus. 115.

Nearctopsylla, 78, 90.

Neopsylla facete, 98.

Neopsylla grandis, 100.

Neopsylla tesior, 99.

Neopsylla wenmanni, 96 .

Neosorex albibarbis, 114.

Neotoma pennsylvanicus, 117.

niger, 54, 119.

Nosopsyllus, 30, 73 .

Nycteridopsylla chapini, 107.

oculaturs, 74 .

Odocoileus virginianus, 119.

Odontopsyllus, $30,46$.

onaga, 103, 114.

Ondatra zibethica, 117.

Opisocrostis, 30, 42.

Opisodasys, 30,56 .

Orchopeas, $30,58$.

Oropsylla, 30, 44.

Oryzomys palustris, 117.

Otus asio, 119.

pallulorum. 10.

Parascalops breweri, 114

Passer domesticus, 120.

penetrans. 12.

pennsylvanicus, 63 .

pentacanthus, 38 .

Peromysci, 71.

Peromyscopsylla, 8, 78, 84.

Peromyscus leucopus, 117.

Petrochelidon albifrons, 119.

Pitymys pinctorum, 117.

Planesticus migratorius, 120.

Preservation, 1.

Procyon lotor, 115.

Progne subis, 119.

pseudagyrtes, 34, 114, 115, 119.

pseudarctomys, 57.

Pulex, 18.

Pulicidae, 7, 13.

quirini, 67, 70, 116.

Pattus norvegicus, 117.

Rattus rattus, 118.

Rattus r. alexandrinus, 118.

Rectofrontia, 29, 38.

Rhopalopsyllus, 29,30 .

Rhadinopsylla fratema, 38.

Rhynchoprionidae, 9.

rilevi, 50.

Riparia riparia, 119.

riparius, 55, 119. 
Sarcopsyllidae, 9.

Sarcopsyllus, 10.

Scalopus aquaticus, 114.

Sciurus carolinensis, 118.

Sciurus hudsonicus, 118.

Sciurus niger, 118.

scotti, 84, 86, 117.

segnis, 88 .

Seiurus aurocapillus, 120 .

selenis, 110.

serraticeps, 26.

sexdentatus, 63 .

Sialia sialis, 119.

Sigmodon hispidus, 118.

silantiewii. 44.

similis, 966.

simplex, 21, 114, 115, 116, 119.

Siphonaptera, 7 .

Spilagale ambarvalis, 115.

Spilopsyllus, 21.

spinifrons, 84.

stanfordi, 41, 116.

Stenoponia, 77, 81.

Sternopsylla, 104, 108.

striata, 100.

Strix varia, 119.

Sturnus vulgaris, 120.

subulata, 105.

Sus scrofa, 119.

Suctoria, 7 .

swansoni, 56.

Sylvilagus floridanus, 118.

Synonymic Index, 111.
Tadarida cynocephala, 115.

tahavuana, 78, 114.

talpae, 78.

Tamias striatus, 118.

Tamiophila, 78, 100.

Taxidea taxus, 116.

Terminology, 2.

testor, 99.

texana, 108, 115.

Trichopsylla, 29, 32 .

tripectinata, 81.

Troglodytes aedon, 120.

Tunga, 12.

Tungidae, 9.

Typhlopsylla americana, 39.

Typhlopsylla assimilis, 34 .

Typhlopsylla fraterna, 38 .

Typhlopsylla pentacanthus, 38.

Urocyon cinereoargenteus, 116.

vison, 67, 72, 115 .

Vulpes fulva, 116.

Vulpes regalis, 116.

wagneri, 67, 71, 116.

walkeri, 67.

wenmanni, 96, 114, 115, 116.

wetmorei, 81 .

wickhami, 59, 114, 115, 119.

Xenopsylla, 13, 16.

Xestopsylla, 10.

Zapus hudsonicus, 118. 
PLATES 
PLATE I

Epitedia wenmanni (Rothschild), female, and Ceratophyllus idius Jordan and Rothschild, male genitalia, illustrating structural terms. 
antepygidial bristks
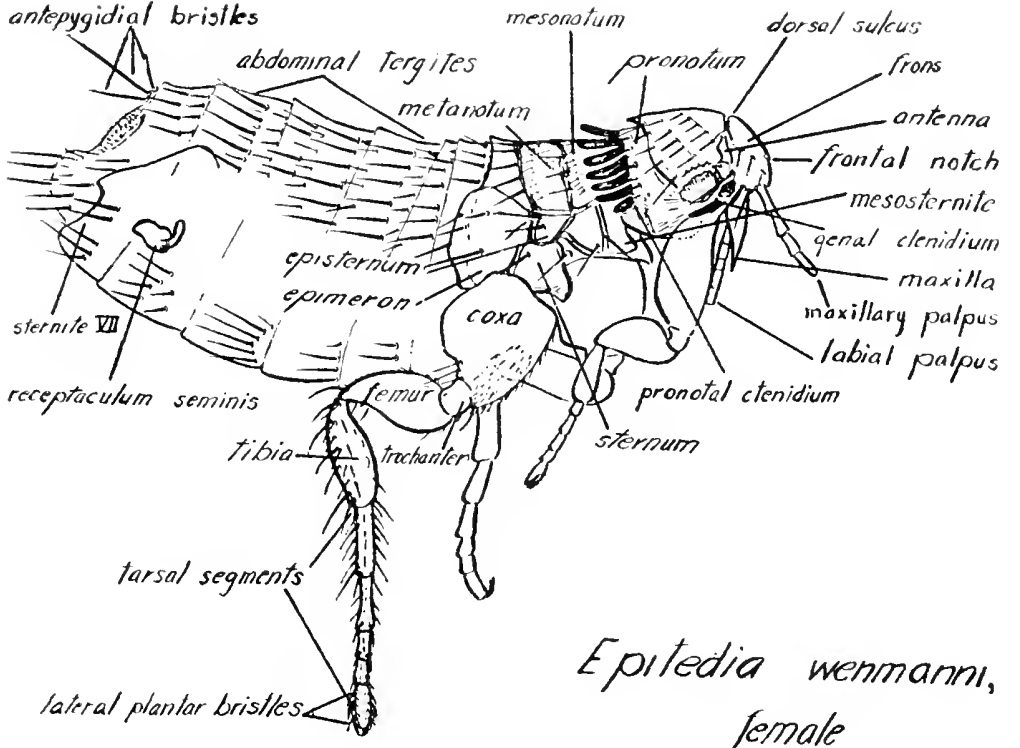

Eprledia wenmannı, female

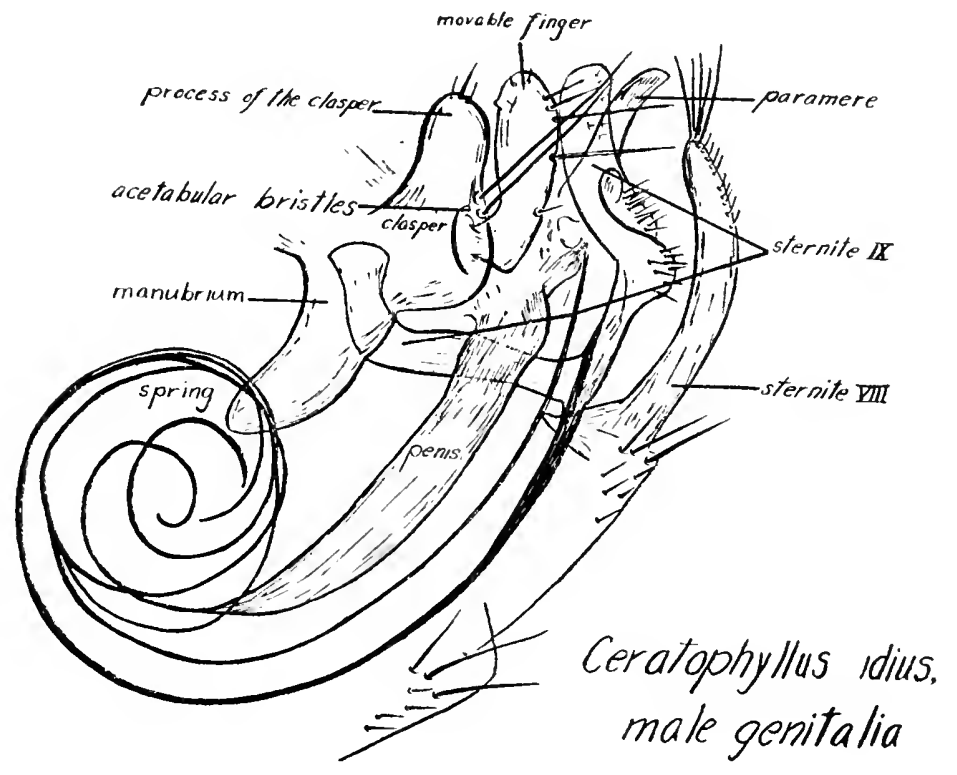


Echidnophaga gallinacea (Westwood)

\section{Figure}

1. Receptaculum seminis.

2. Posterior end of the female abdomen.

3. Male genitalia.

4. Head, thorax, and first abdominal tergite of male.

5. Hind coxa of male showing patch of spinelets on inner side. 
Plates

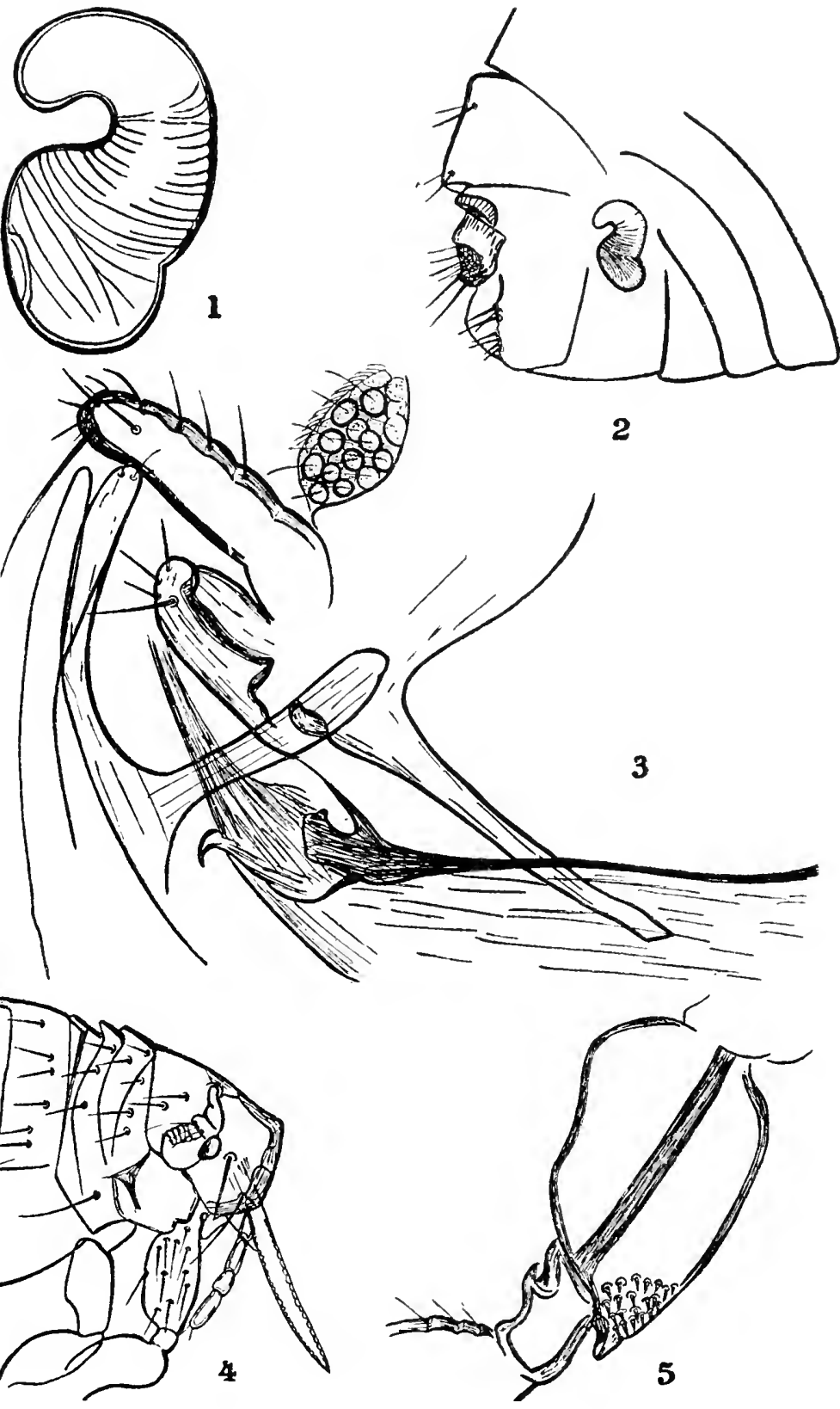




\section{PLATE III}

\section{Figure}

6. Cediopsylla simplex (Baker), receptaculum seminis.

7. Idem, male genitalia.

8. Tunga penetrans (Linnaeus), male genitalia.

9. Idem, head of male.

10. Cediopsylla simplex (Baker), head of female. 

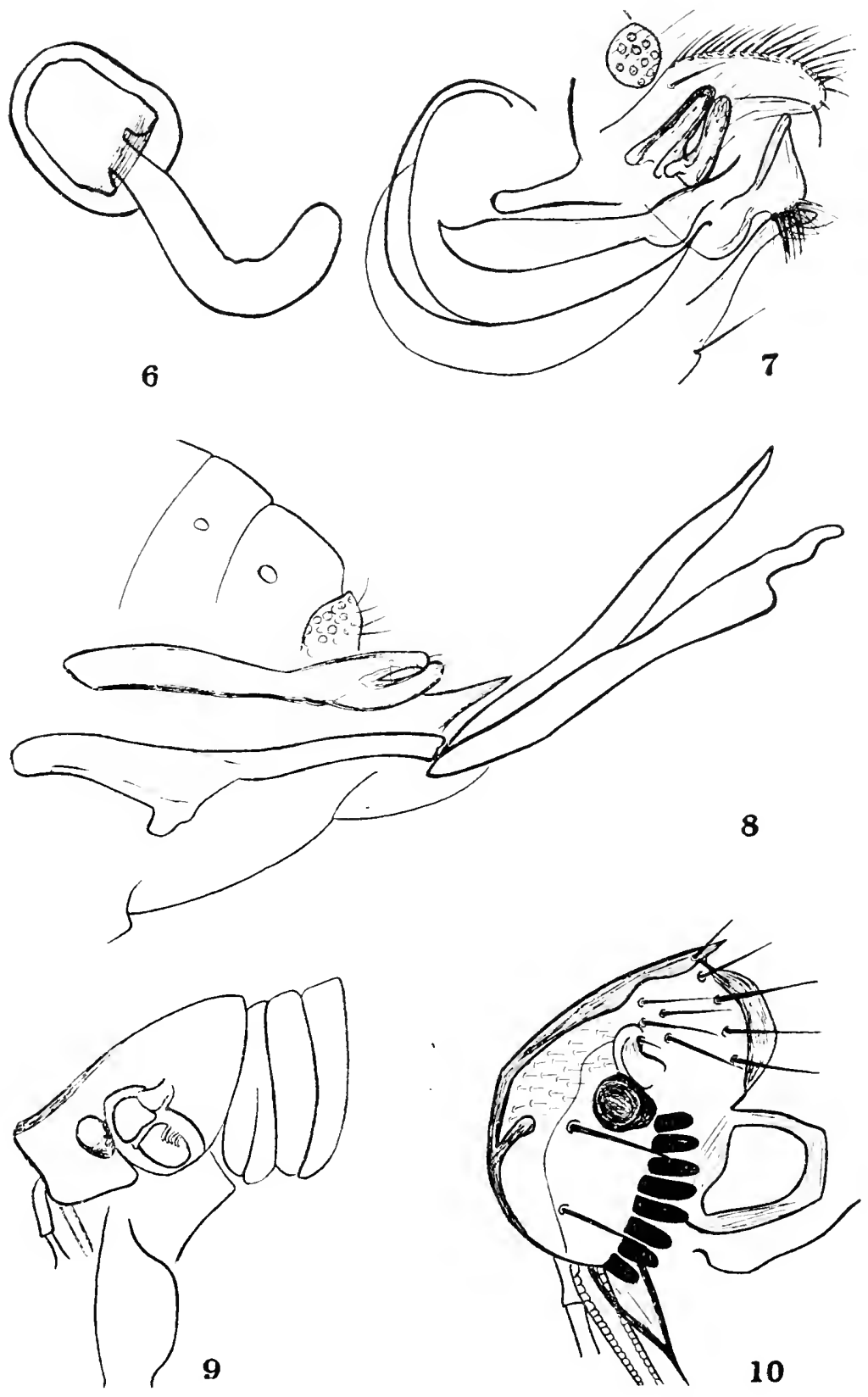


\section{PLATE IV}

\section{Figure}

11. Hoplopsyllus lynx (Baker), receptaculum seminis.

12. Hoplopsyllus affinis (Baker), head of female.

13. Hoplopsyllus lynx (Baker), process of the clasper.

14. Hoplopsyllus affinis (Baker), male genitalia.

15. Idem, receptaculum seminis. 


$$
\text { Plates }
$$

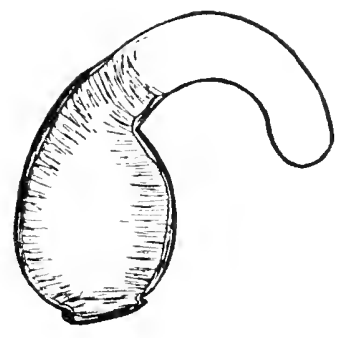

11
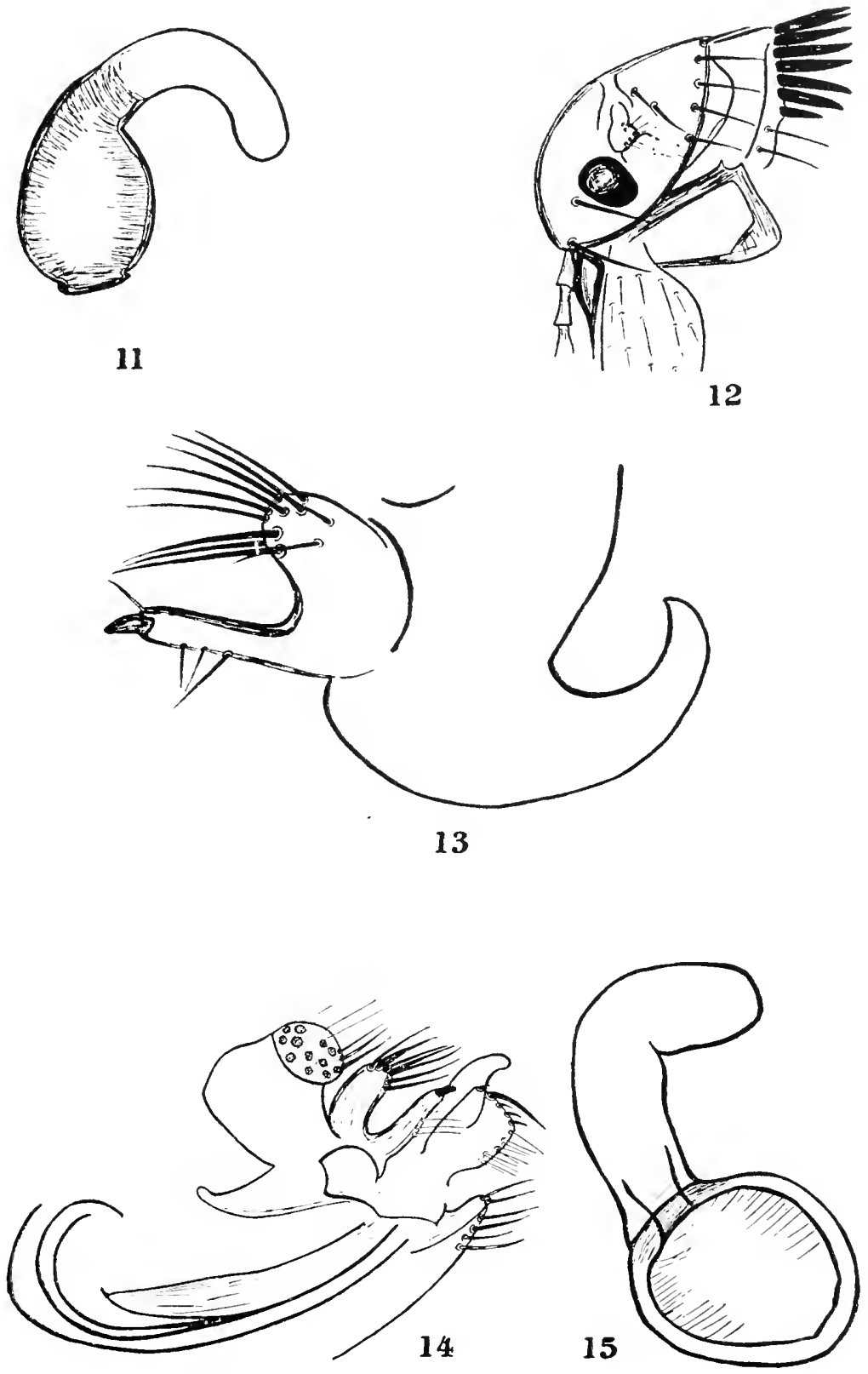


\section{PLATE V}

\section{Figure}

16. Xenopsylla cheopis (Rothschild), male genitalia.

17. Pulex irritans Linnaeus, male genitalia.

18. Xenopsylla cheopis (Rothschild), receptaculum seminis.

19. Pulex irritans Linnaeus, receptaculum seminis.

20. Xenopsylla cheopis (Rothschild), head of male.

21. Pulex irritans Linnaeus, head of female. 
Plates

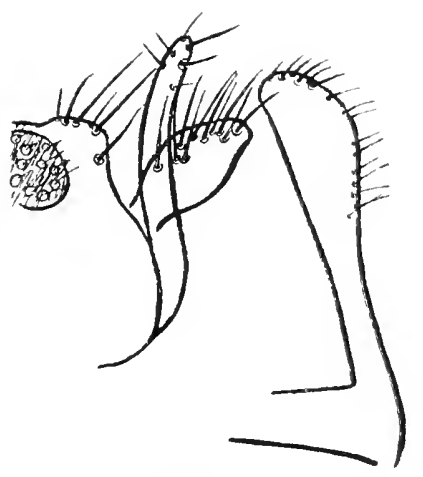

16

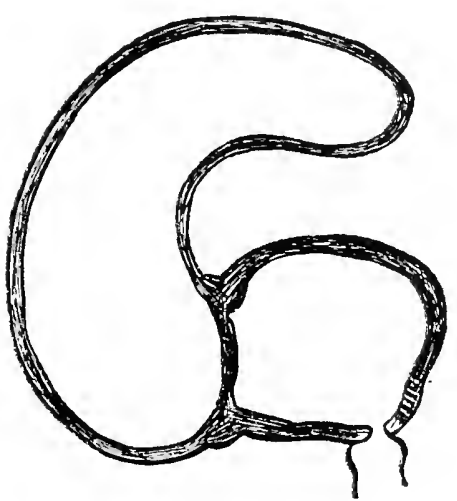

18

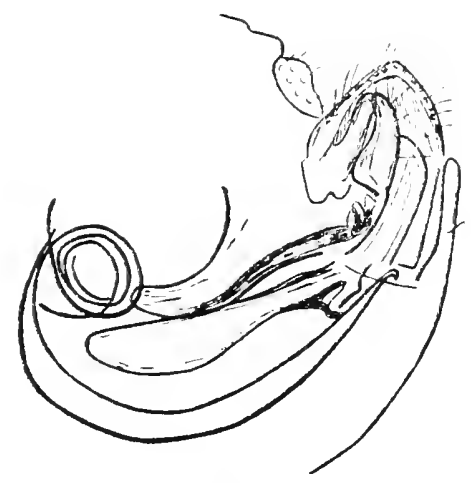

17

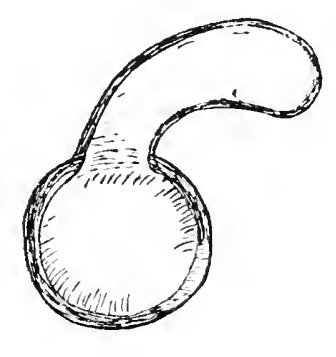

19
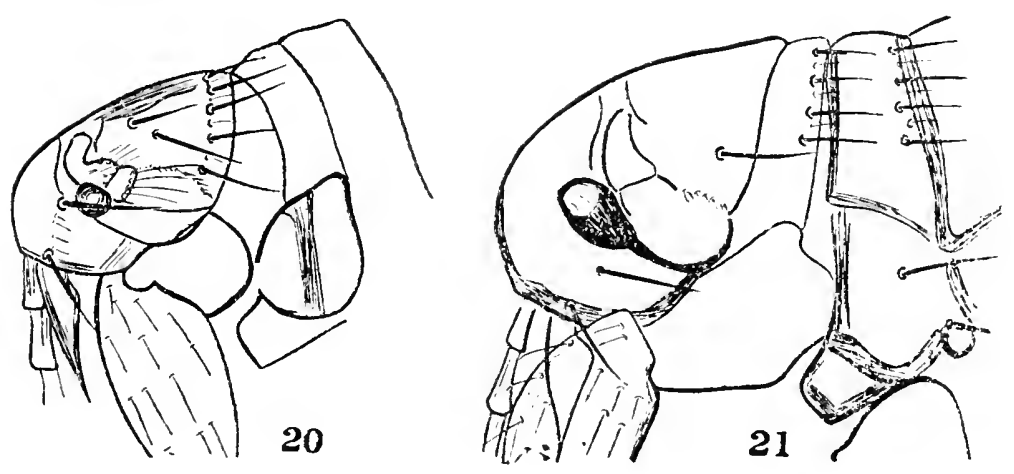


\section{PLATE VI}

\section{Figure}

22. Ctenocephalides felis (Bouché), head of female.

23. Idem, head of male.

24. Ctenocephalides canis (Curtis), head of male.

25. Ctenocephalides felis (Bouché), male genitalia.

26. Ctenocephalides canis (Curtis), head of female.

27. Idem, receptaculum seminis. 


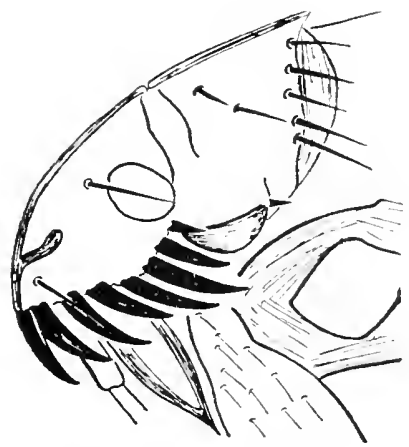

22

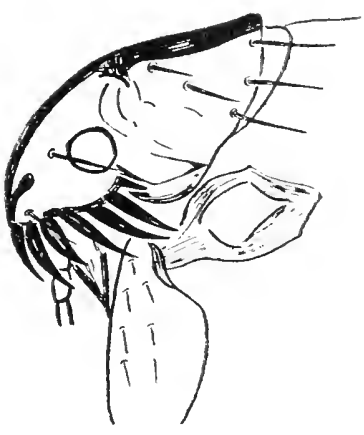

23
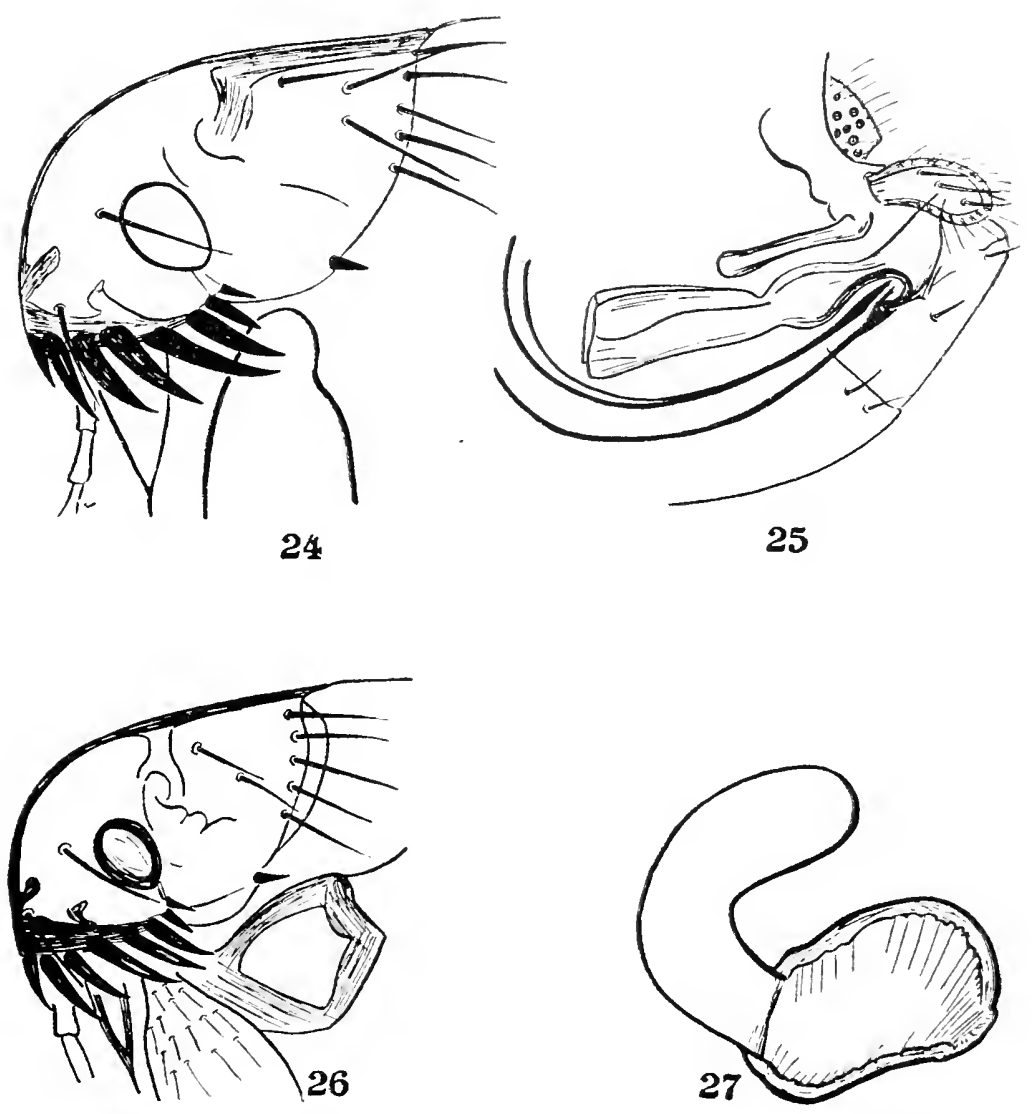


\section{PLATE VII}

\section{Figure}

28. Rhopalopsyllus gwyni C. Fox, head of male.

29. Odontopsyllus multispinosus Baker, head of female.

30. Idem, male genitalia.

31. Idem, receptaculum seminis and sternite VII.

32. Rhopalopsyllus gwyni C. Fox, male genitalia.

33. Idem, receptaculum seminis and sternite VII. 
Plates
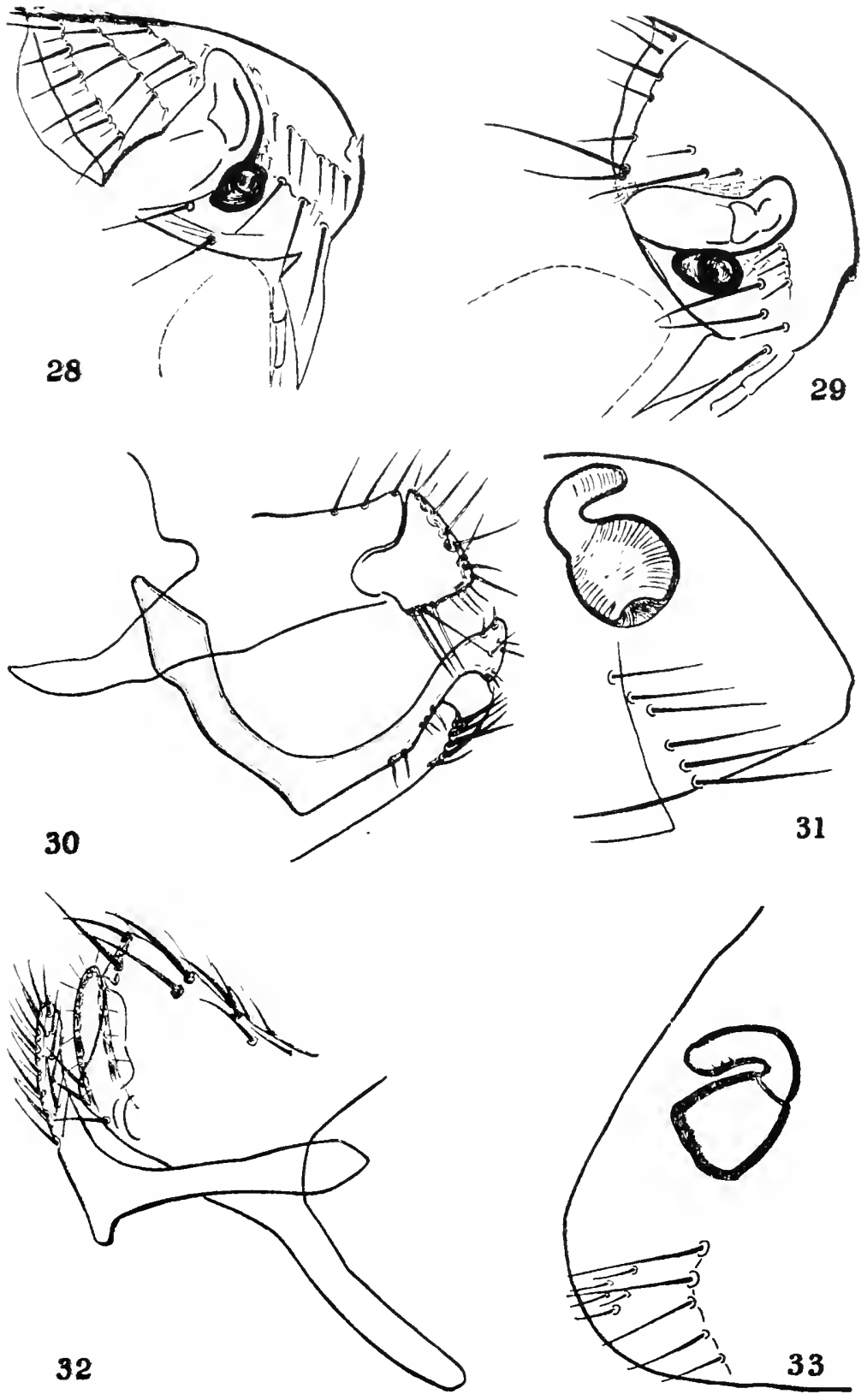


\section{Figure}

34. Trichopsylla floridensis I. Fox, head of female.

35. Trichopsylla lotoris Stewart, head of female.

36. Trichopsylla floridensis I. Fox, metepimeron.

37. Trichopsylla lotoris Stewart, metepimeron.

38. Idem, receptaculum seminis.

39. Trichopsylla floridensis I. Fox, male genitalia. 

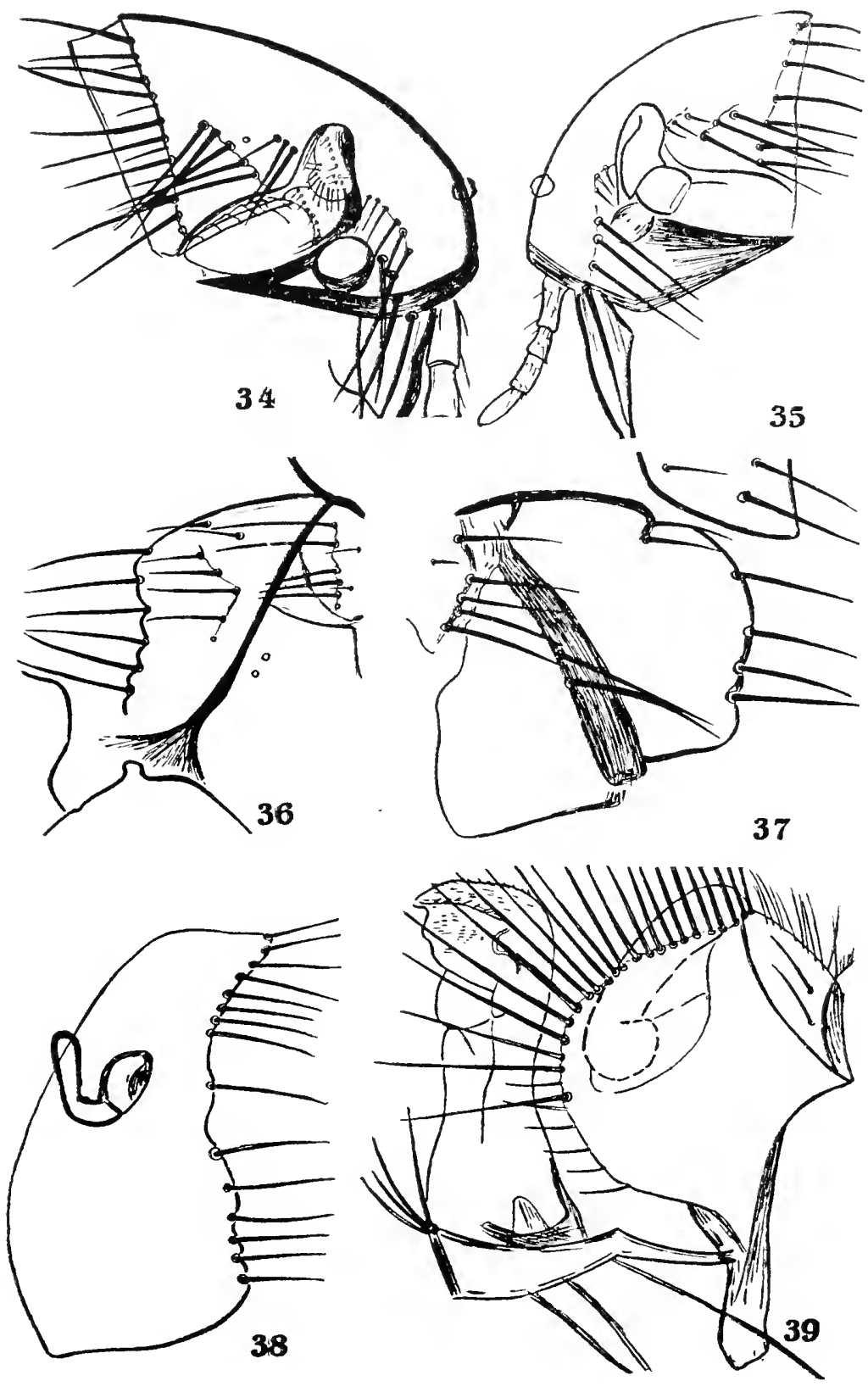


\section{PLATE IX}

\section{Figure}

40. Oropsylla arctomys (Baker), movable finger and process of clasper.

41. Idem, head of female.

42. Trichopsylla lotoris Stewart, movable finger and manubrium.

43. Oropsylla arctomys (Baker), receptaculum seminis. 
Plates
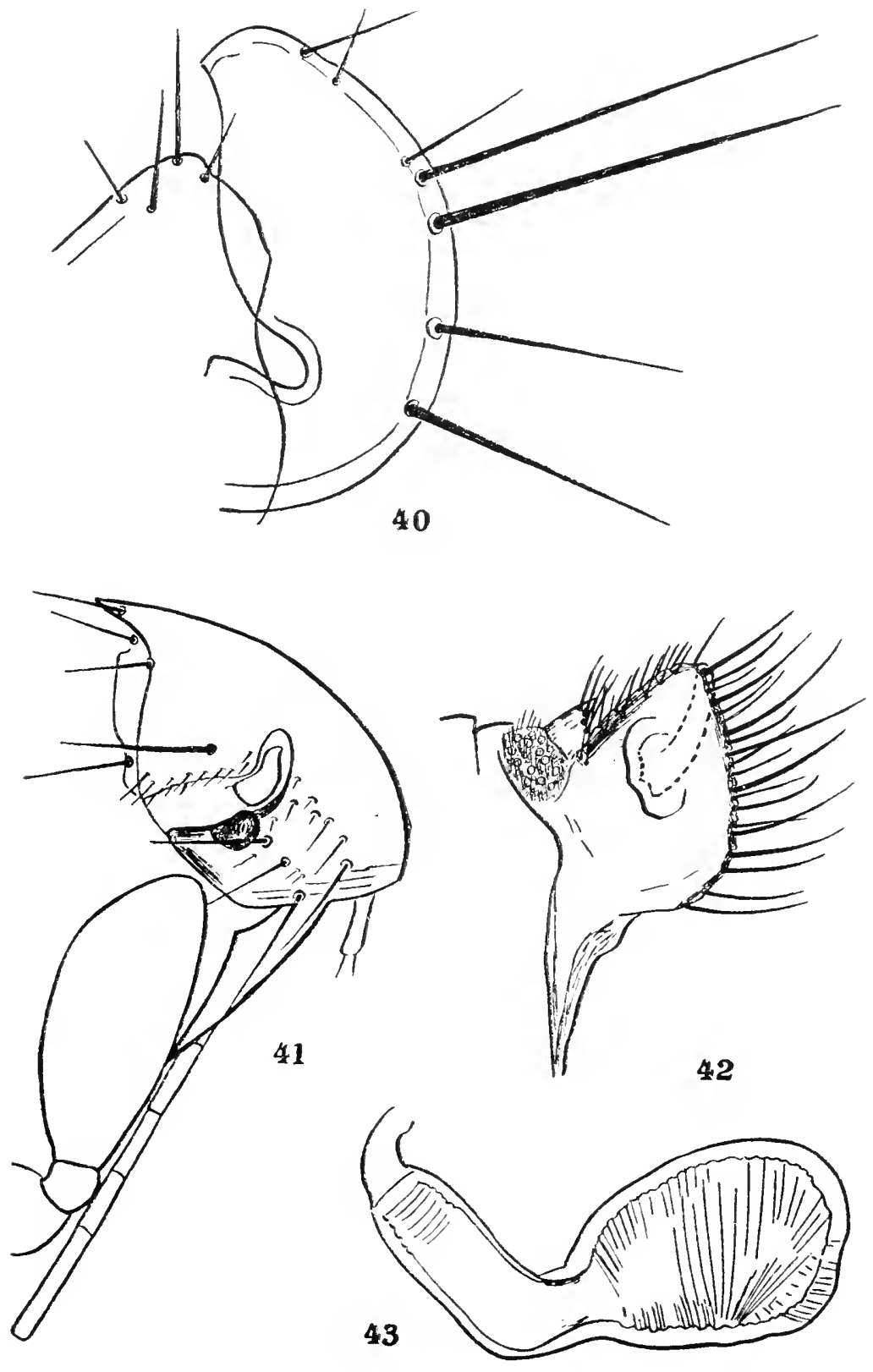


\section{PLATE X}

\section{Figure}

44. Rectofrontia fraterna (Baker), head of female.

45. Ctenophthalmus pseudagyrtes Baker, head of male.

46. Idem, receptaculum seminis.

47. Rectofrontia fraterna (Baker), male genitalia.

48. Idem, receptaculum seminis.

49. Ctenophthalmus pseudagyrtes, movable finger and process of clasper. 
Plates
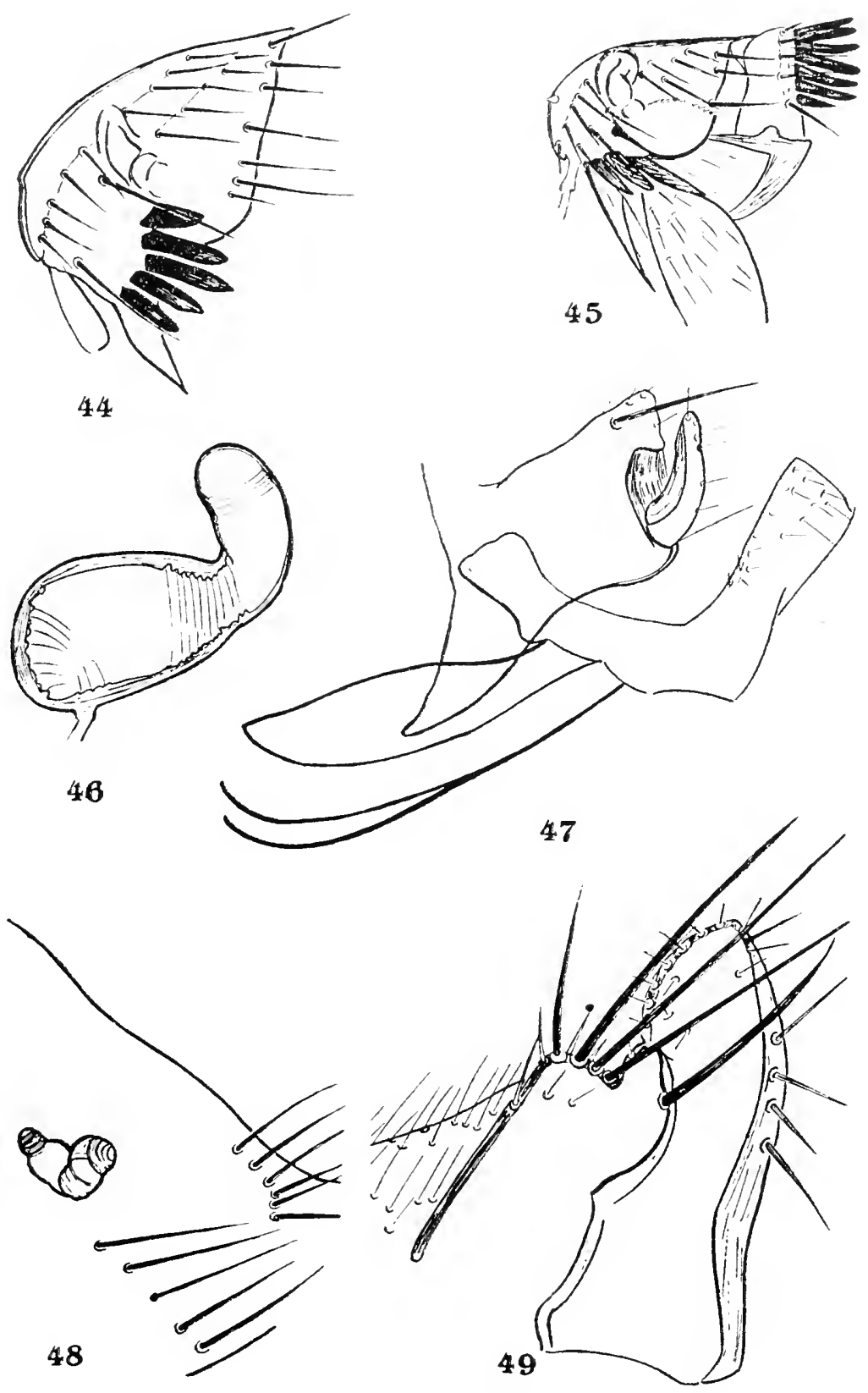


\section{PLATE XI}

\section{Figure}

50. Opisocrostis bruneri (Baker), head of male.

51. Idem, movable finger and process of the clasper.

52. Foxella ignotus (Baker), receptaculum seminis.

53. Opisocrostis bruneri (Baker), receptaculum seminis.

54. Foxella ignotus (Baker), movable finger and process of clasper.

55. Idem, head of male. 
Plates
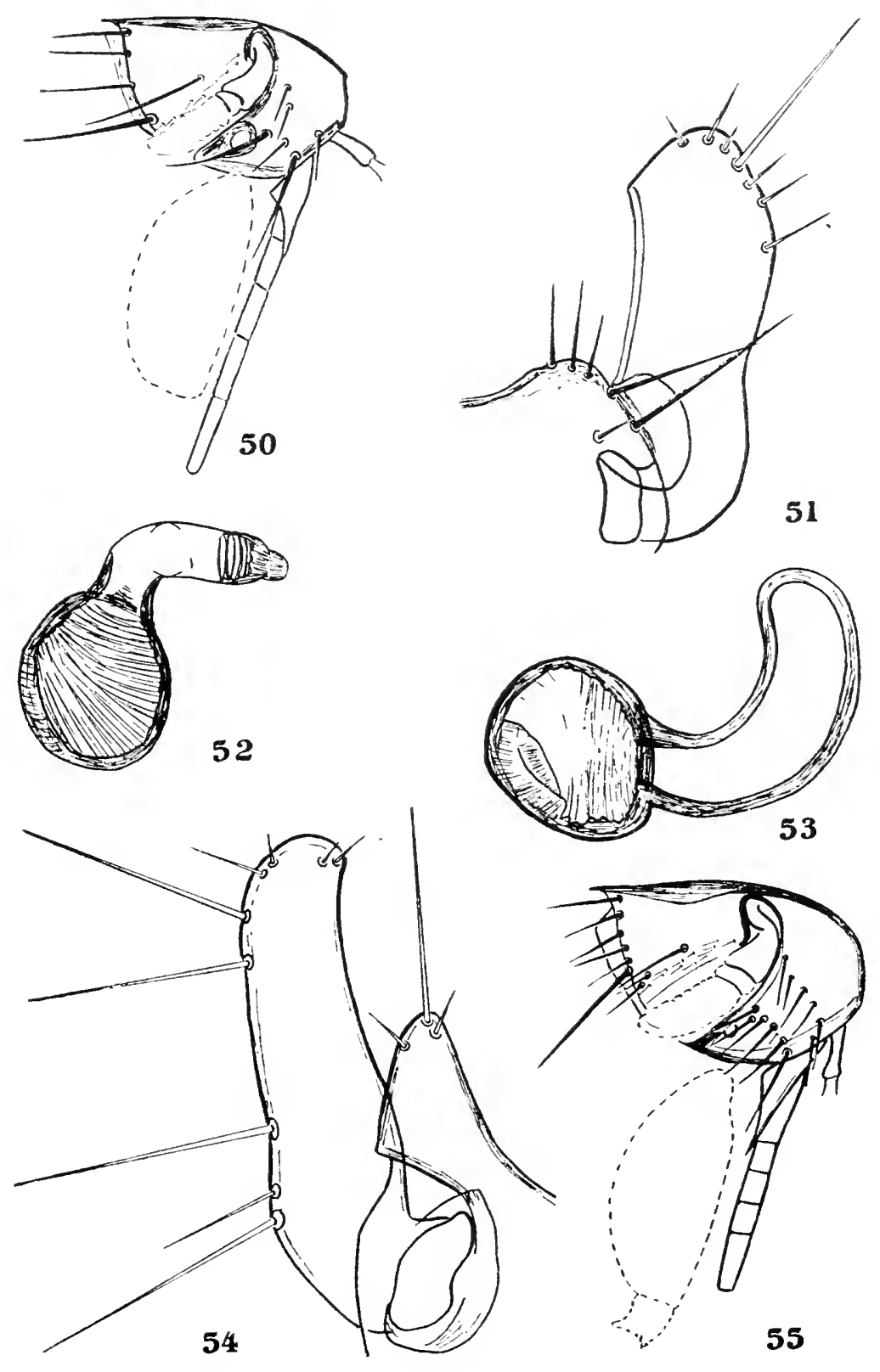


\section{PLATE XII}

\section{FIGURE}

56. Ceratophyllus celsus Jordan, male genitalia.

57. Idem, receptaculum seminis and sternite VII.

58. Ceratophyllus diffinis Jordan, receptaculum seminis and sternite VII.

59. Idem, male genitalia.

60. Ceratophyllus idius Jordan and Rothschild, receptaculum seminis and sternite VII.

61. Idem, male genitalia. 
Plates

153
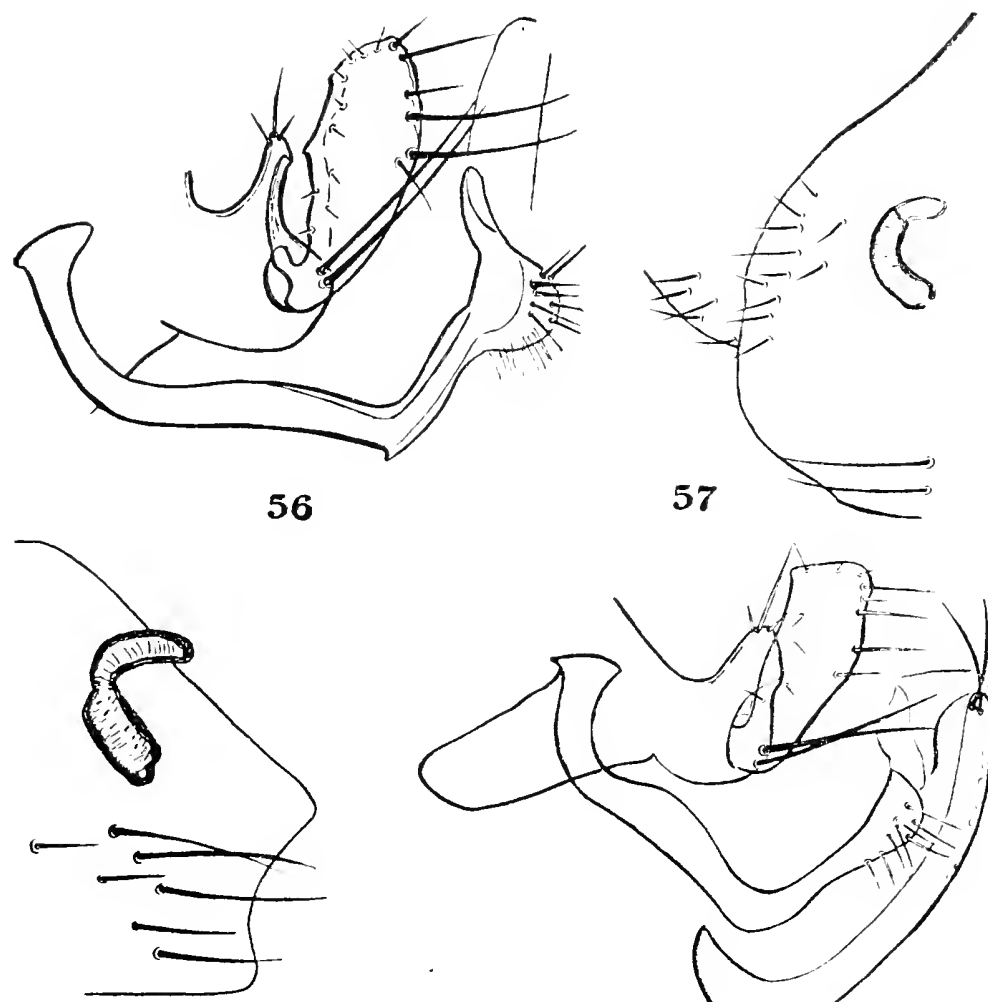

58
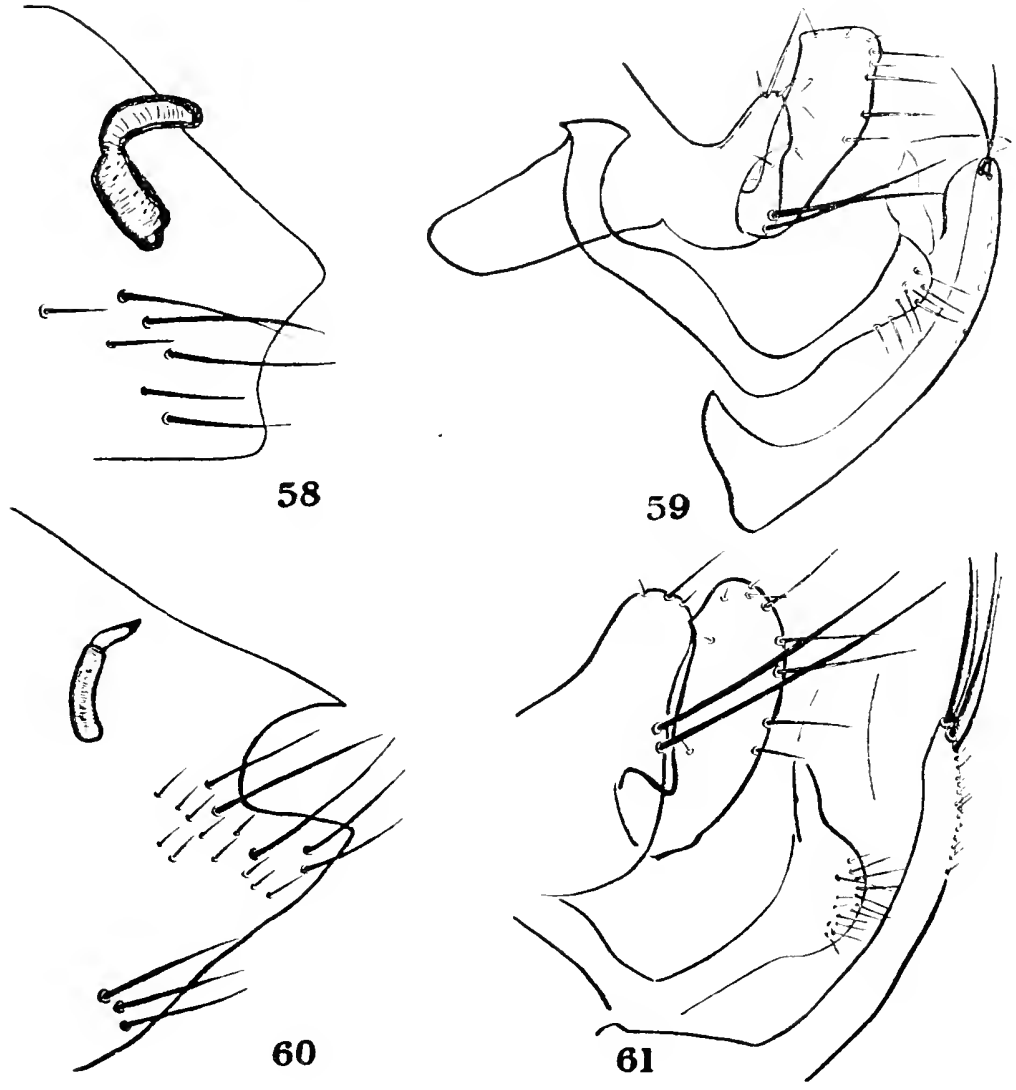


\section{Figure}

62. Ceratophyllus gallinae (Schrank), male genitalia.

63. Idem, receptaculum seminis and sternite VII.

64. Ceratophyllus niger C. Fox, male genitalia.

65. Idem, receptaculum seminis and sternite IX.

66. Ceratophyllus riparius Jordan and Rothschild, sternite IX.

67. Idem, male genitalia. 
Plates
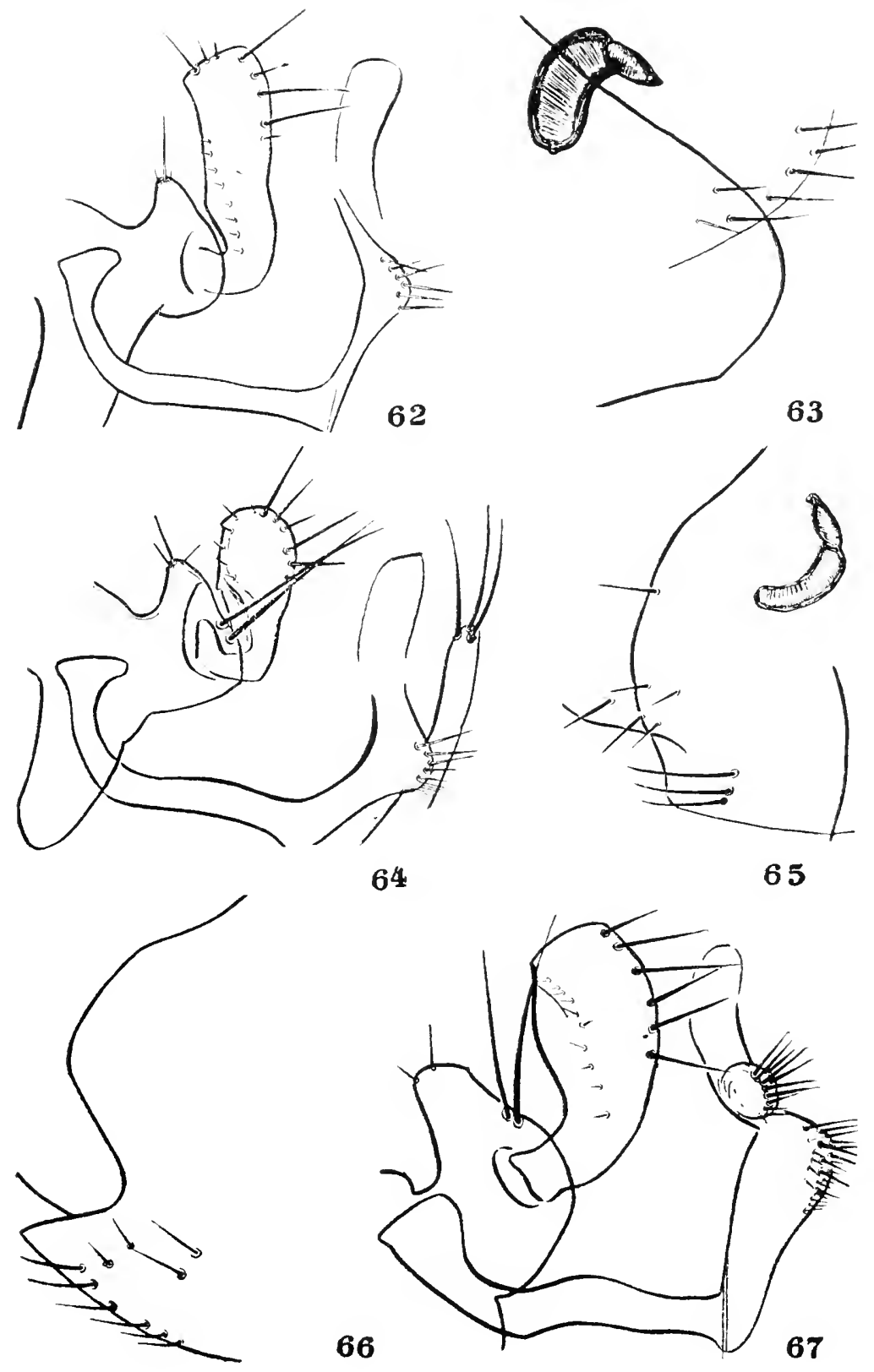

64

65

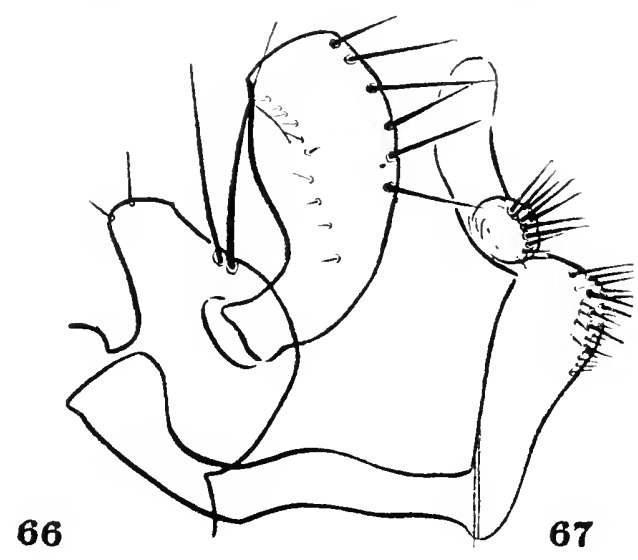




\section{PLATE XIV}

\section{Figure}

68. Opisodasys pseudarctomys (Baker), head of male.

69. Idem, posterior end of female abdomen.

70. Ceratophyllus swansoni Liu, male genitalia.

71. Idem, receptaculum seminis and sternite VII.

72. Opisodasys pseudarctomys (Baker), male genitalia.

73. Ceratophyllus swansoni Liu, head of male. 
Plates

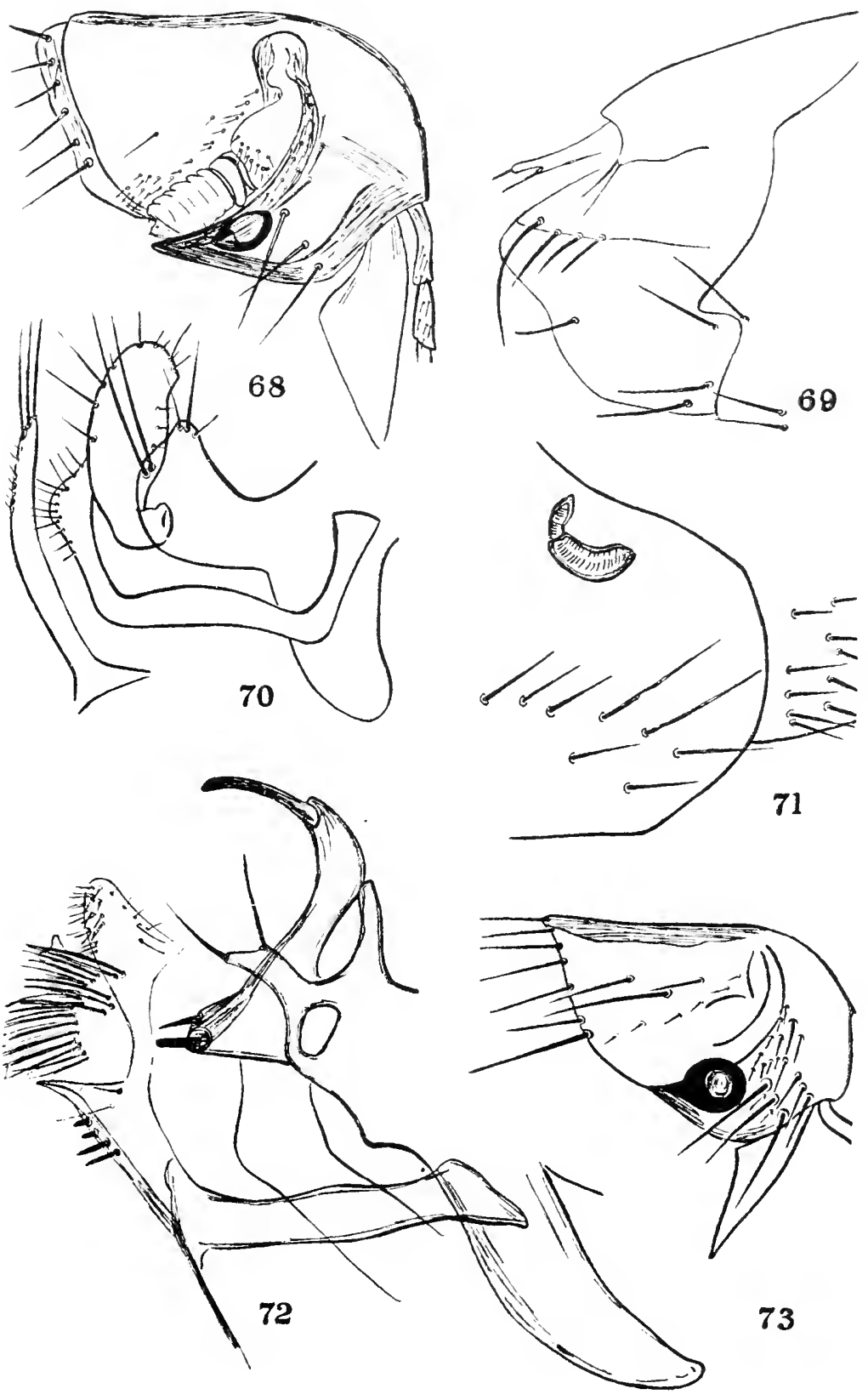


Figure

74. Orchopeas leucopus (Baker), head of male.

75. Orchopeas wickhami (Baker), movable finger and process of clasper.

76. Idem, receptaculum seminis and sternite VII.

77. Idem, head of male.

78. Orchopeas leucopus (Baker), movable finger and process of clasper. 
Plates

159
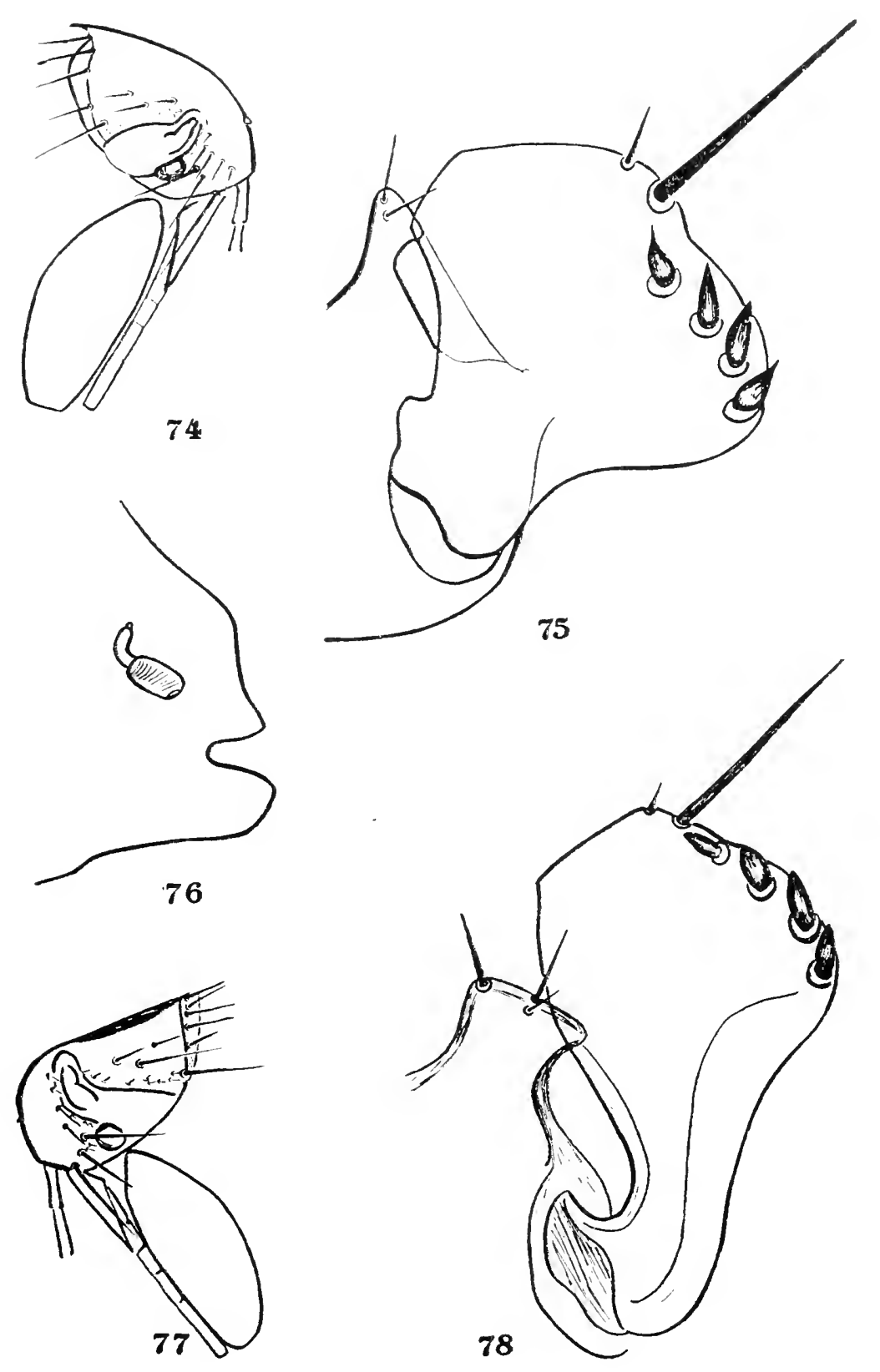


\section{PLATE XVI}

\section{Figure}

79. Orchopeas sexdentatus pennsylvanicus (Jordan), head of male.

80. Orchopeas caedens (Jordan), head of male.

81. Idem, receptaculum seminis and sternite VII.

82. Idem, male genitalia.

83. Orchopeas sexdentatus (Baker), receptaculum seminis and sternite VII.

84. Idem, movable finger and process of clasper. 


\section{Plates}

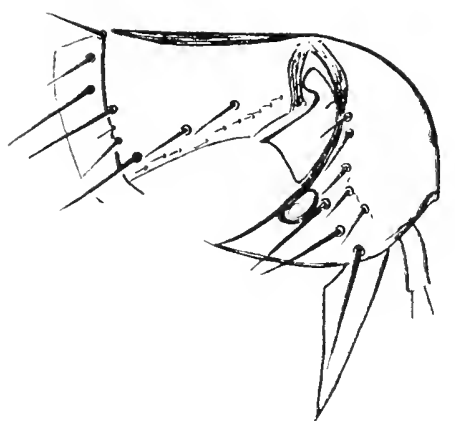

79

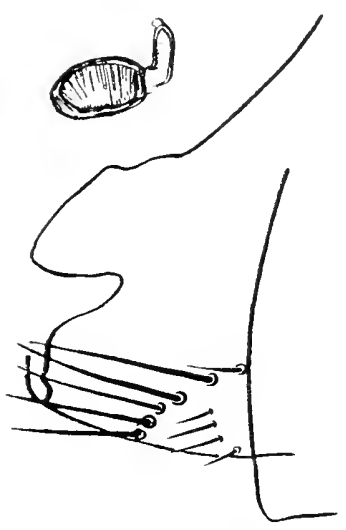

81

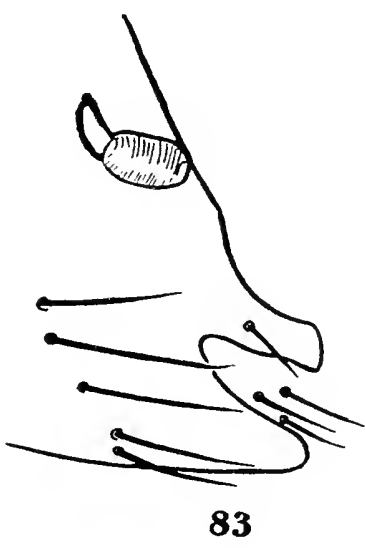

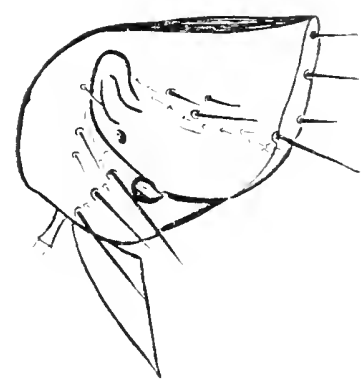

80
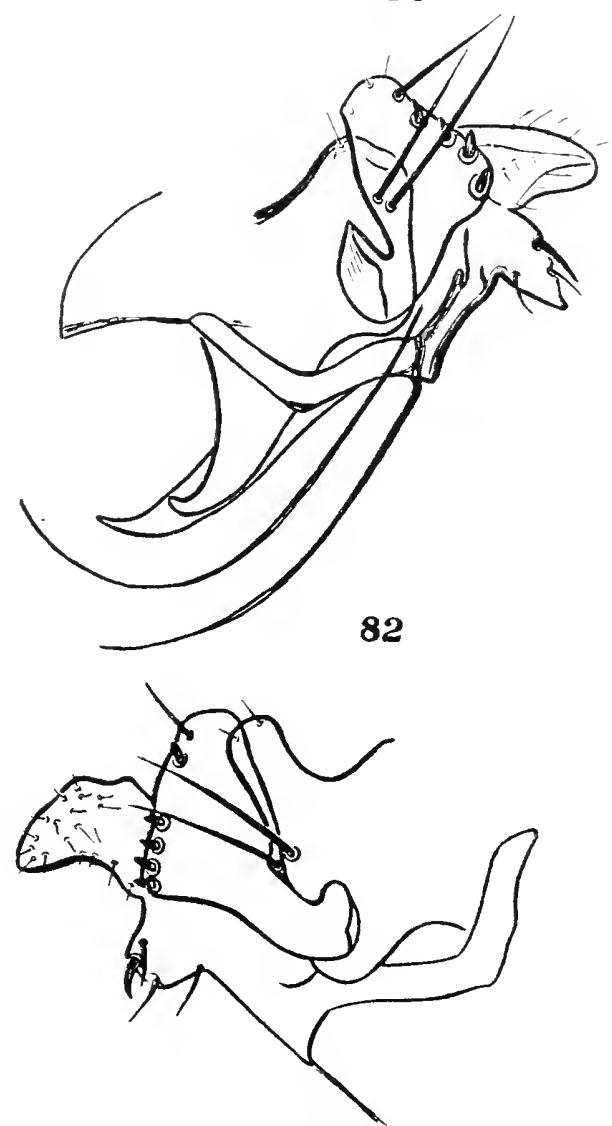

84 


\section{Figure}

85. Megabothris asio (Baker), male genitalia.

86. Idem, receptaculum seminis and sternite VII.

87. Megabothris quirini (Rothschild), male genitalia.

88. Megabothris asio (Baker), head of female.

89. Idem, head of female showing different arrangement of postantennal bristles. 
Plates
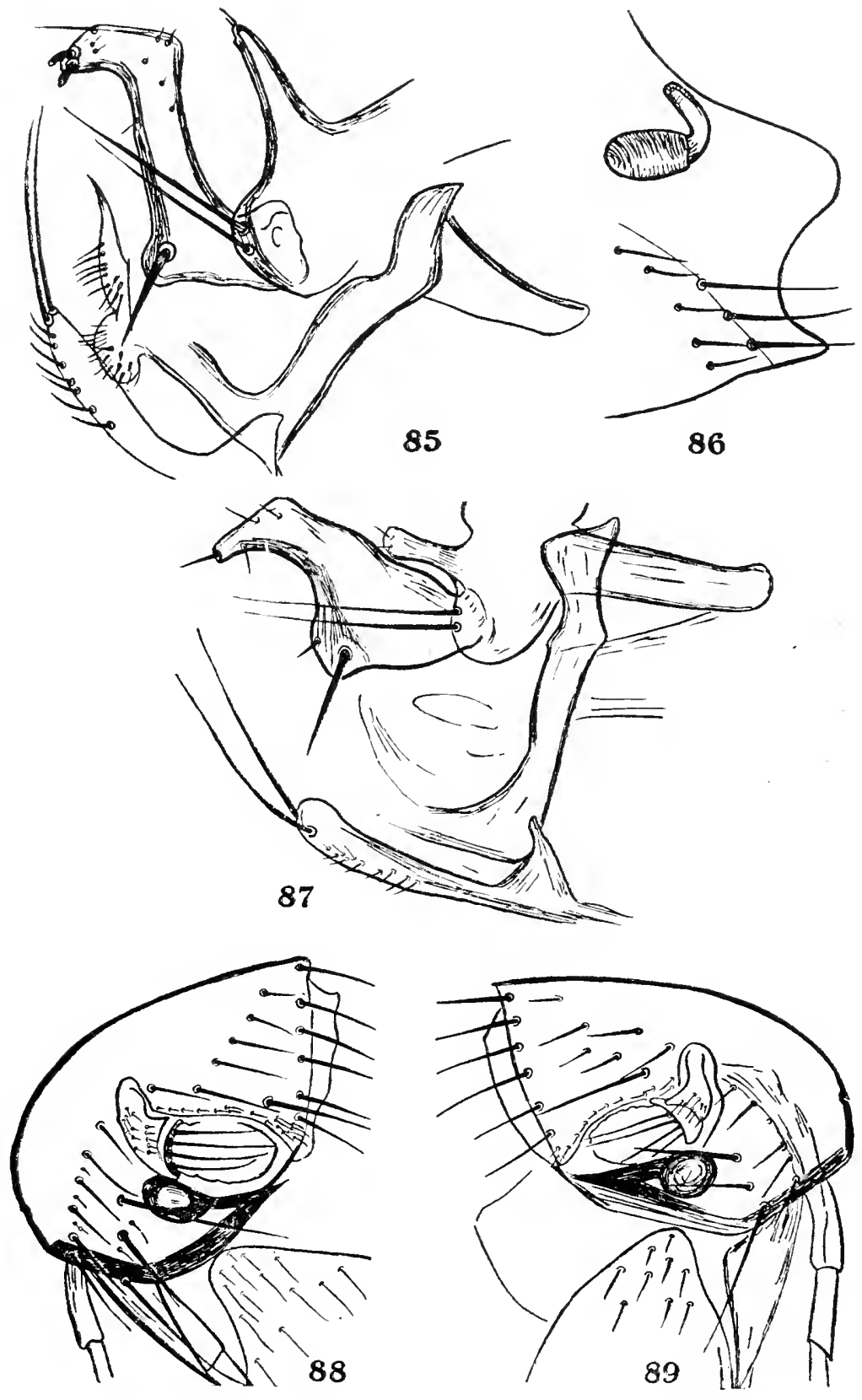


\section{PLATE XVIII}

\section{Figure}

90. Megabothris quirini (Rothschild), head of male.

91. Megabothris acerbus (Jordan), head of female.

92. Idem, male genitalia.

93. Idem, receptaculum seminis and sternite VII.

94. Megabothris quirini (Rothschild), receptaculum seminis and sternite VII. 
Plates
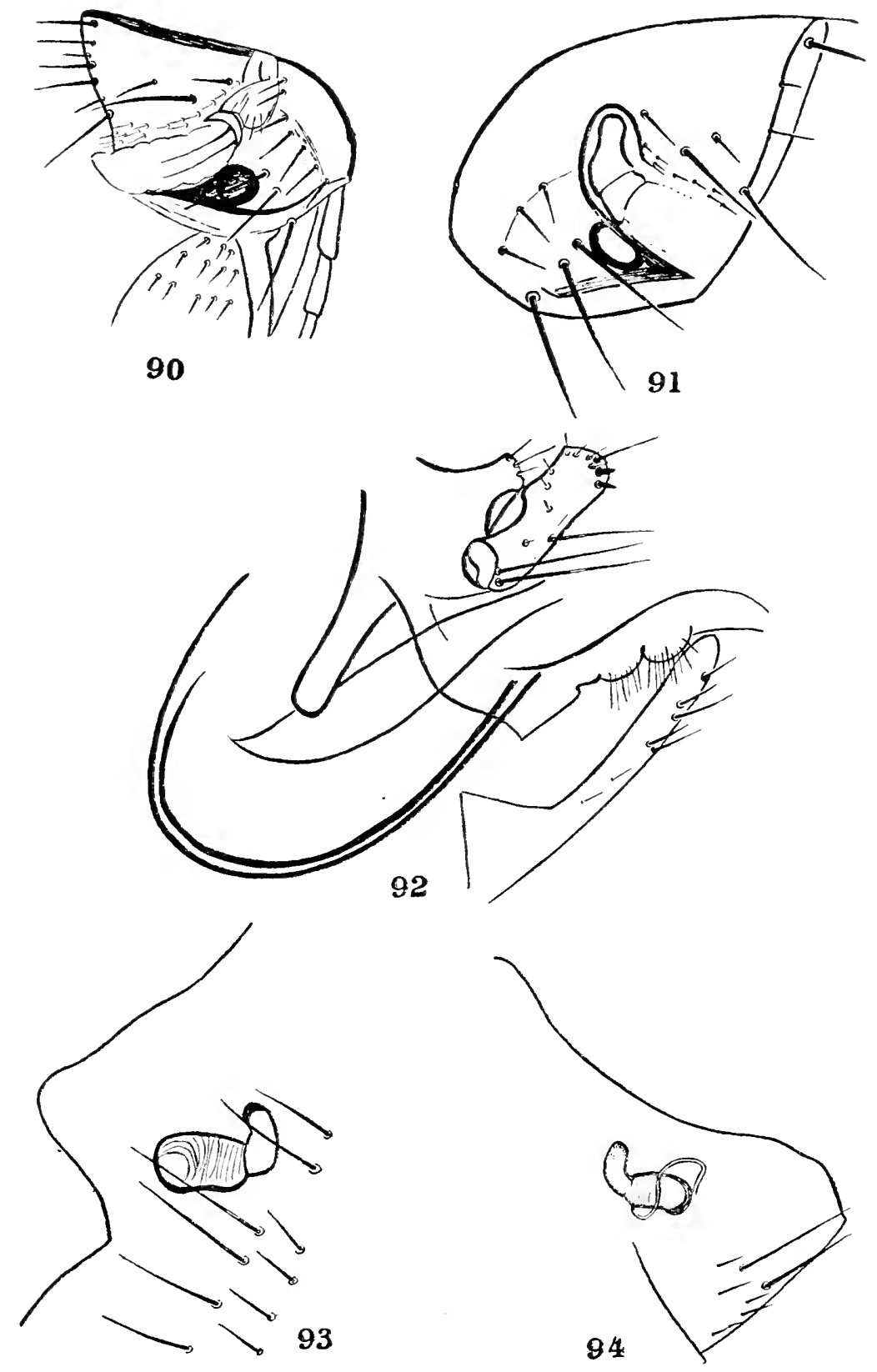
PLATE XIX

\section{Figure}

95. Megabothris vison (Baker), head of male.

96. Megabothris wagneri (Baker), receptaculum seminis.

97. Idem, movable finger and process of clasper.

98. Megabothris vison (Baker), receptaculum seminis and sternite VII.

99. Idem, male genitalia. 
Plates
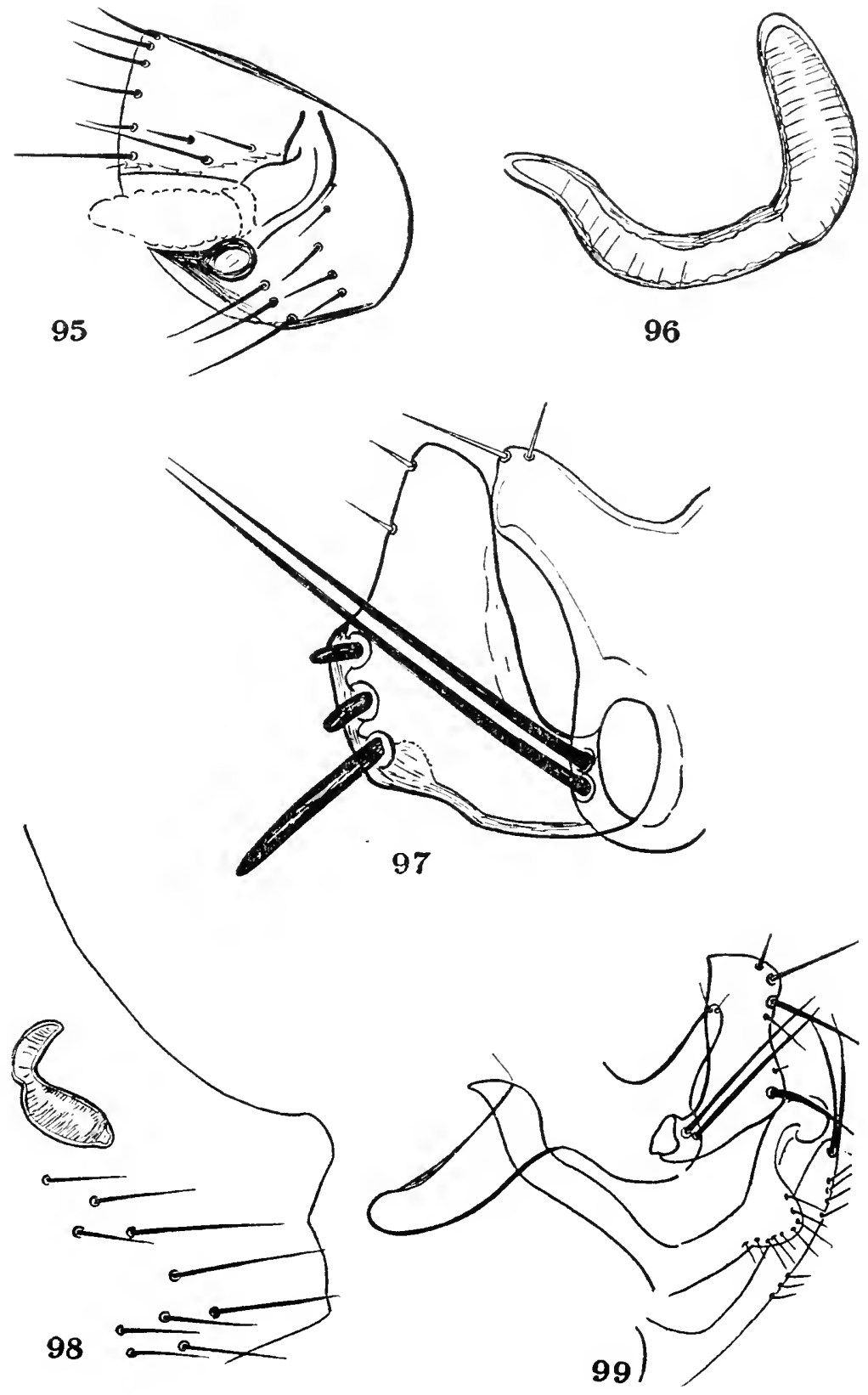


\section{PLATE XX \\ Nosopsyllus fasciatus (Bosc)}

Figure

100. Male genitalia.

101. Head of male.

102. Movable finger and process of clasper.

103. Head of female.

104. Receptaculum seminis and sternite VII. 

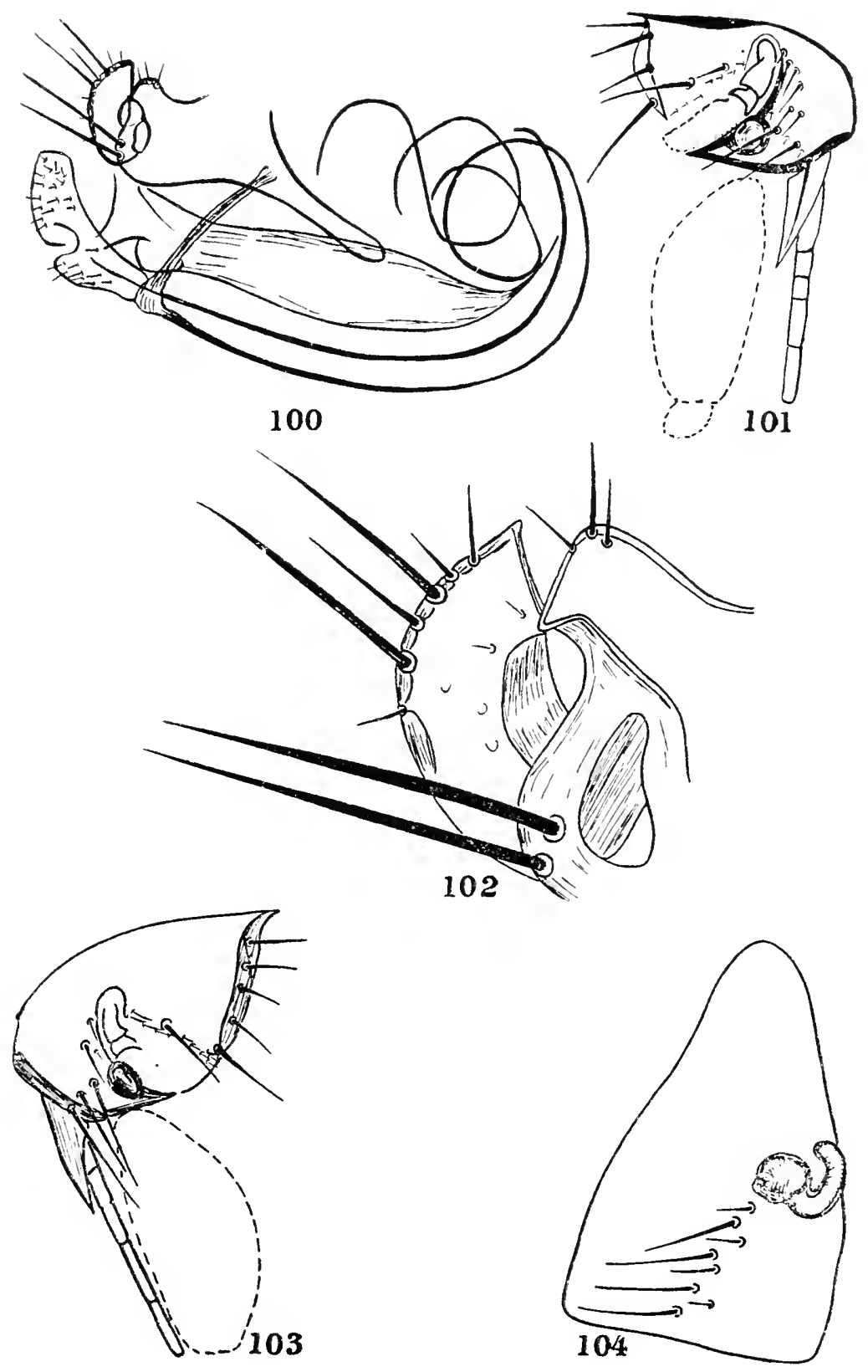


\section{PLATE XXI}

\section{Figure}

105. Atyphloceras bishopi Jordan, movable finger, process of clasper, and sternite IX (after Jordan).

106. Hystrichopsylla gigas tahavuana Jordan, male, posterior arm of sternite IX (after Jordan).

107. Idem, receptacula seminis and sternite VII.

108. Idem, head of female.

109. Atyphloceras bishopi Jordan, receptacula seminis and sternite VII (after Jordan). 

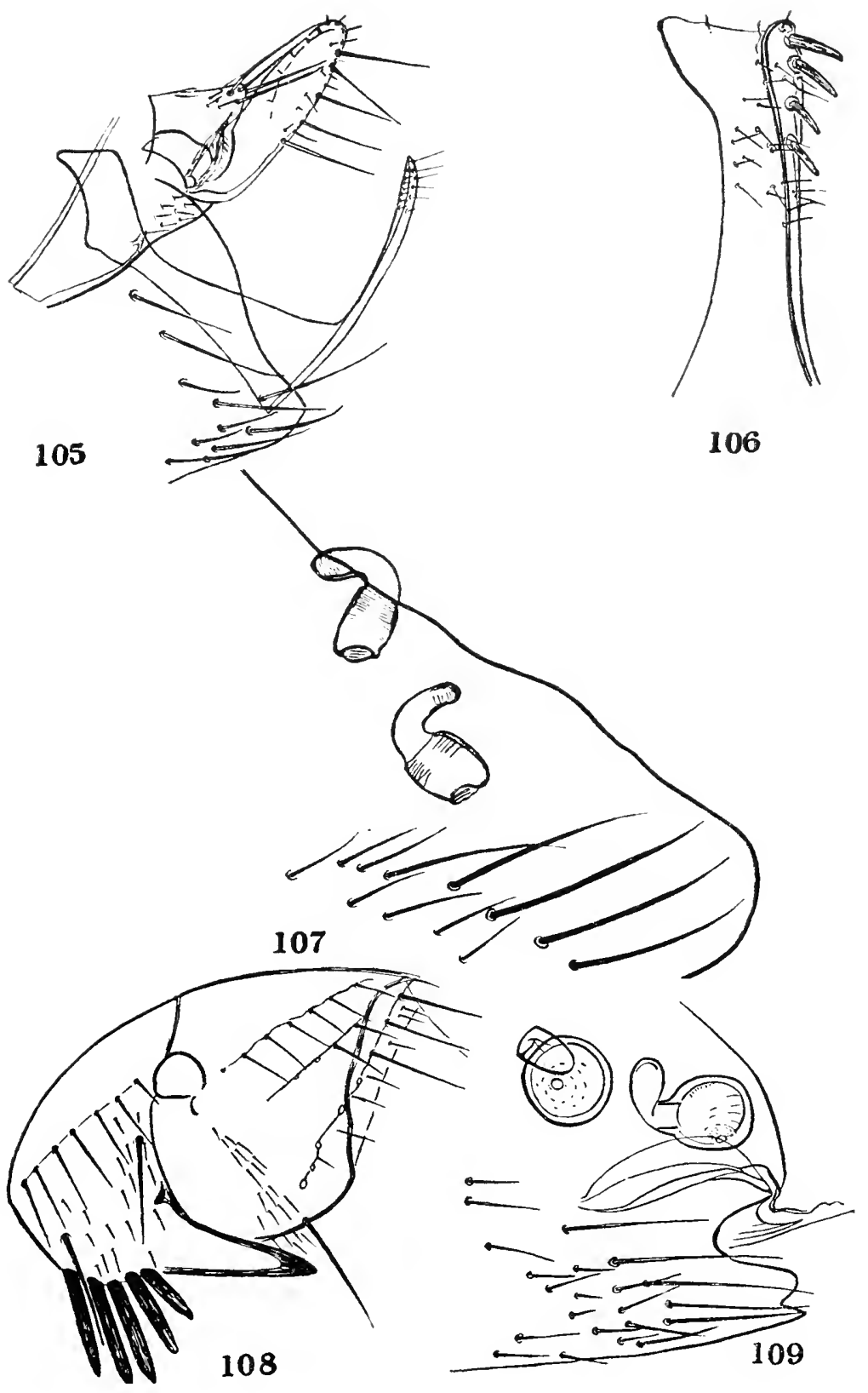


\section{PLATE XXII}

\section{Figure}

110. Peromyscopsylla catatina Jordan, sternite VII of female.

111. Peromyscopsylla scotti I. Fox, genal ctenidium of female.

112. Idem, movable finger and process of clasper.

113. Idem, receptaculum seminis and sternite VII.

114. Peromyscopsylla catatina Jordan, genal ctenidium of male.

115. Idem, male genitalia. 
Plates
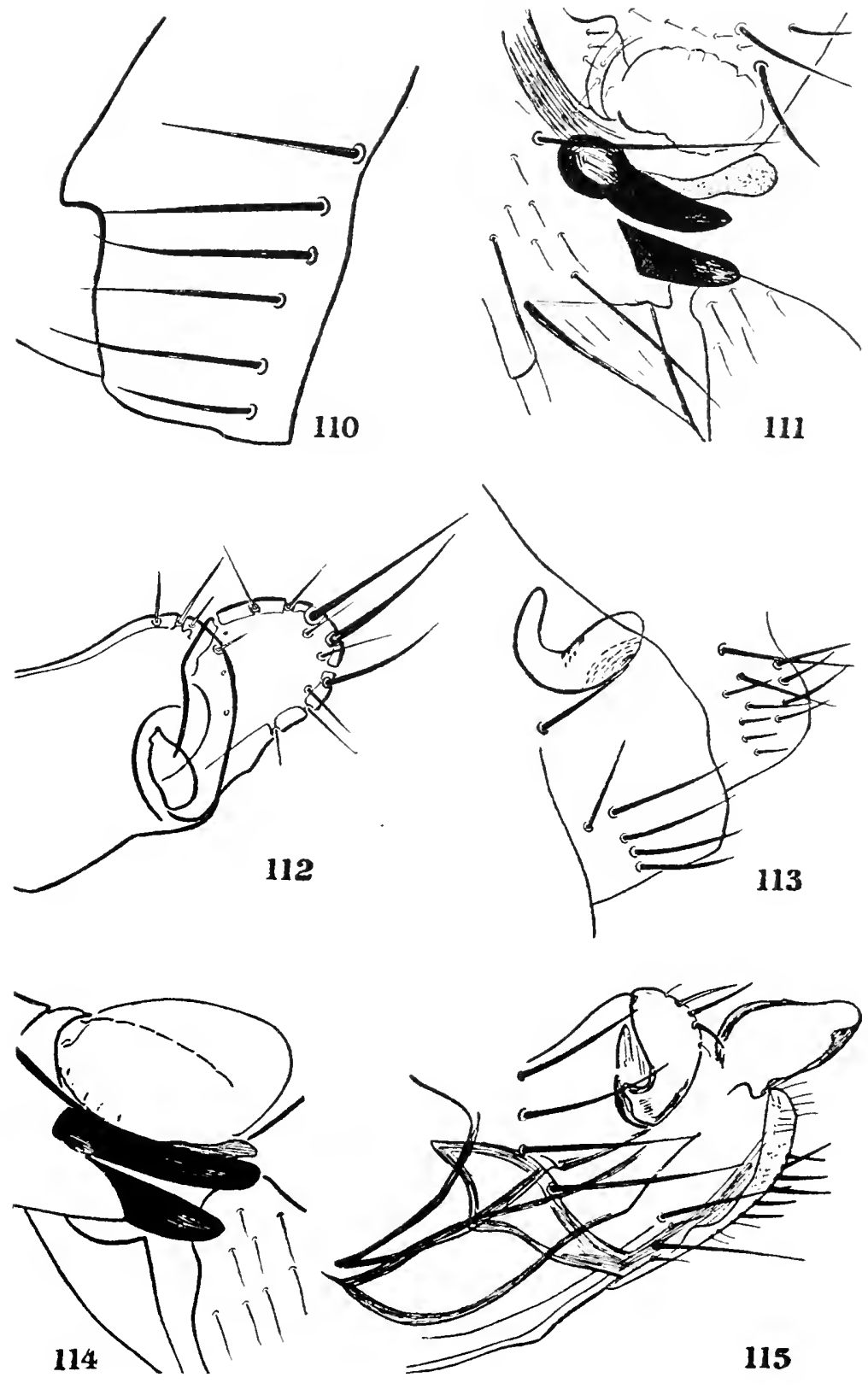
PLATE XXIII

Figure

116. Nearctopsylla genalis (Baker), head of female.

117. Peromyscopsylla hesperomys (Baker), head of female.

118. Idem, receptaculum seminis and sternite VII.

119. Idem, male genitalia.

120. Nearctopsylla genalis (Baker), receptaculum seminis and sternite VII.

121. Idem, male genitalia. 
Plates
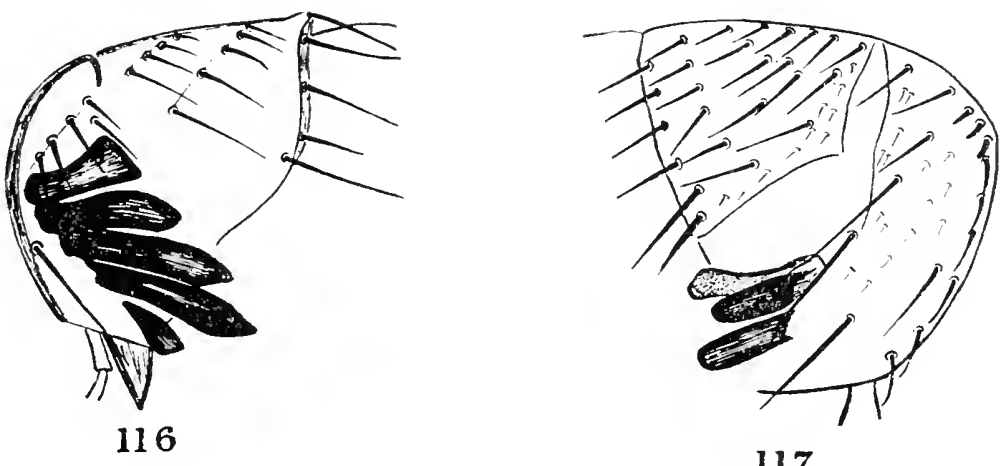

\section{7}
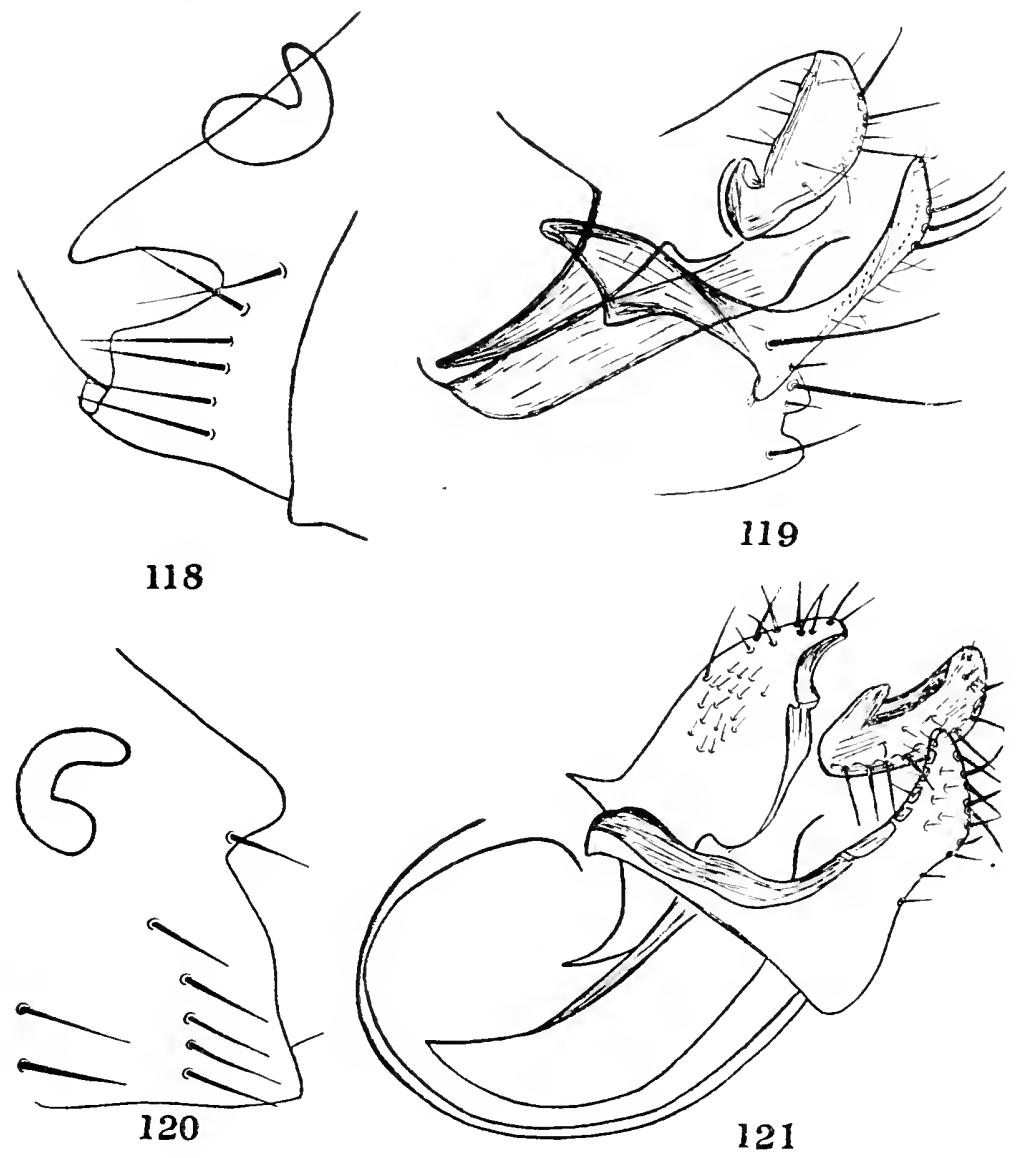
PLATE XXIV

Ctenopsyllus segnis (Schönherr)

Figure

122. Male genitalia.

123. Hind tibia of female.

124. Movable finger and process of clasper.

125. Head of male.

126. Receptaculum seminis and sternite VII. 

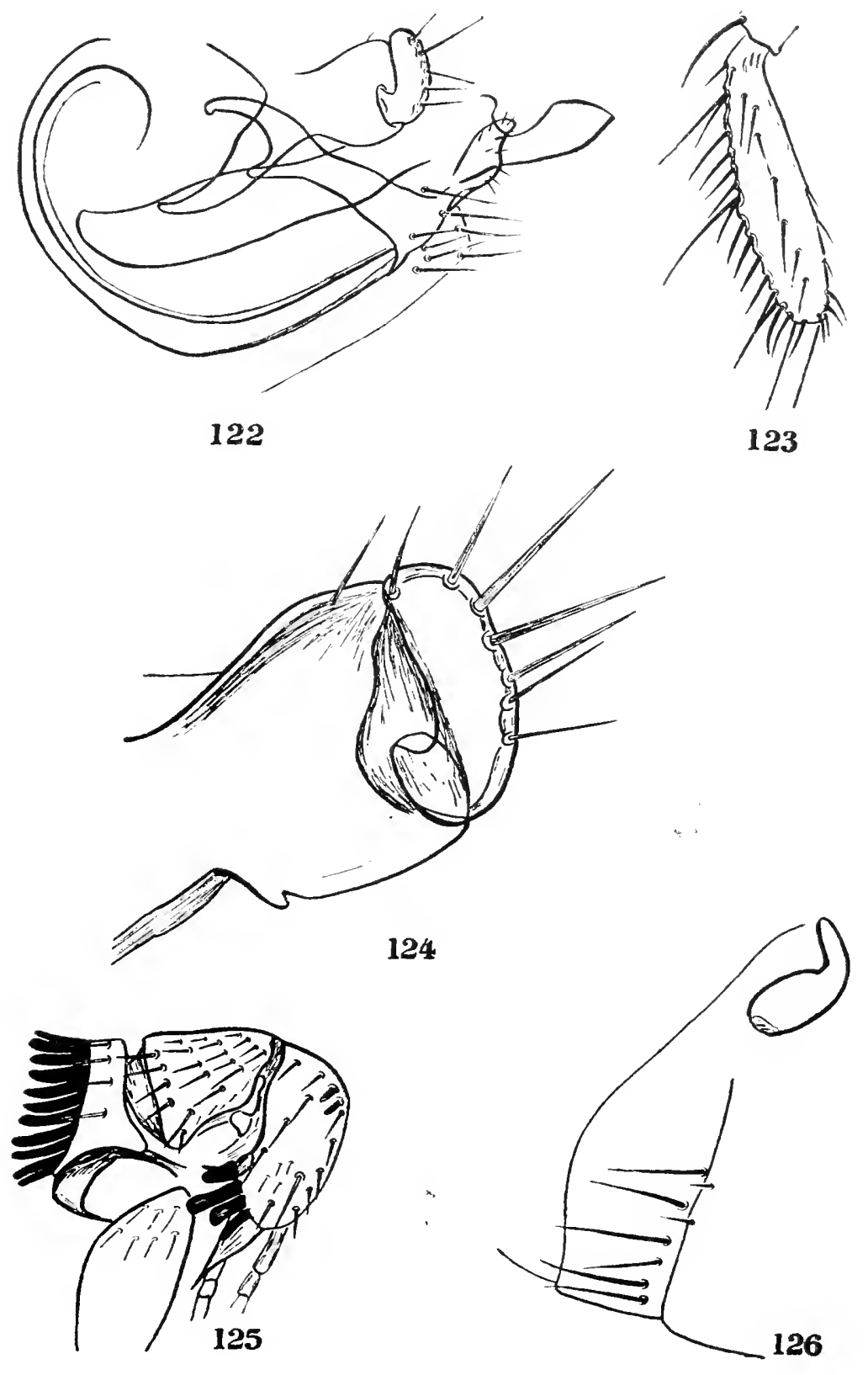

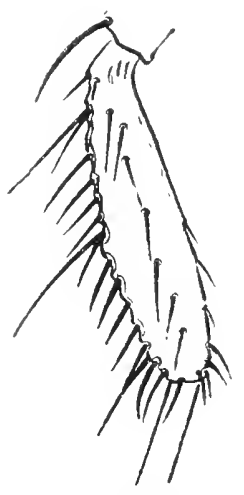

123 


\section{PLATE XXV}

Figure

127. Tamiophila grandis (Rothschild), movable finger, process of clasper, and manubrium.

128. Stenoponia americana (Baker), male genitalia.

129. Tamiophila grandis (Rothschild), receptaculum seminis and sternite VII.

130. Stenoponia americana (Baker), receptaculum seminis and sternite VII.

131. Tamiophila grandis (Rothschild), head of female.

132. Stenoponia americana (Baker), head of female. 

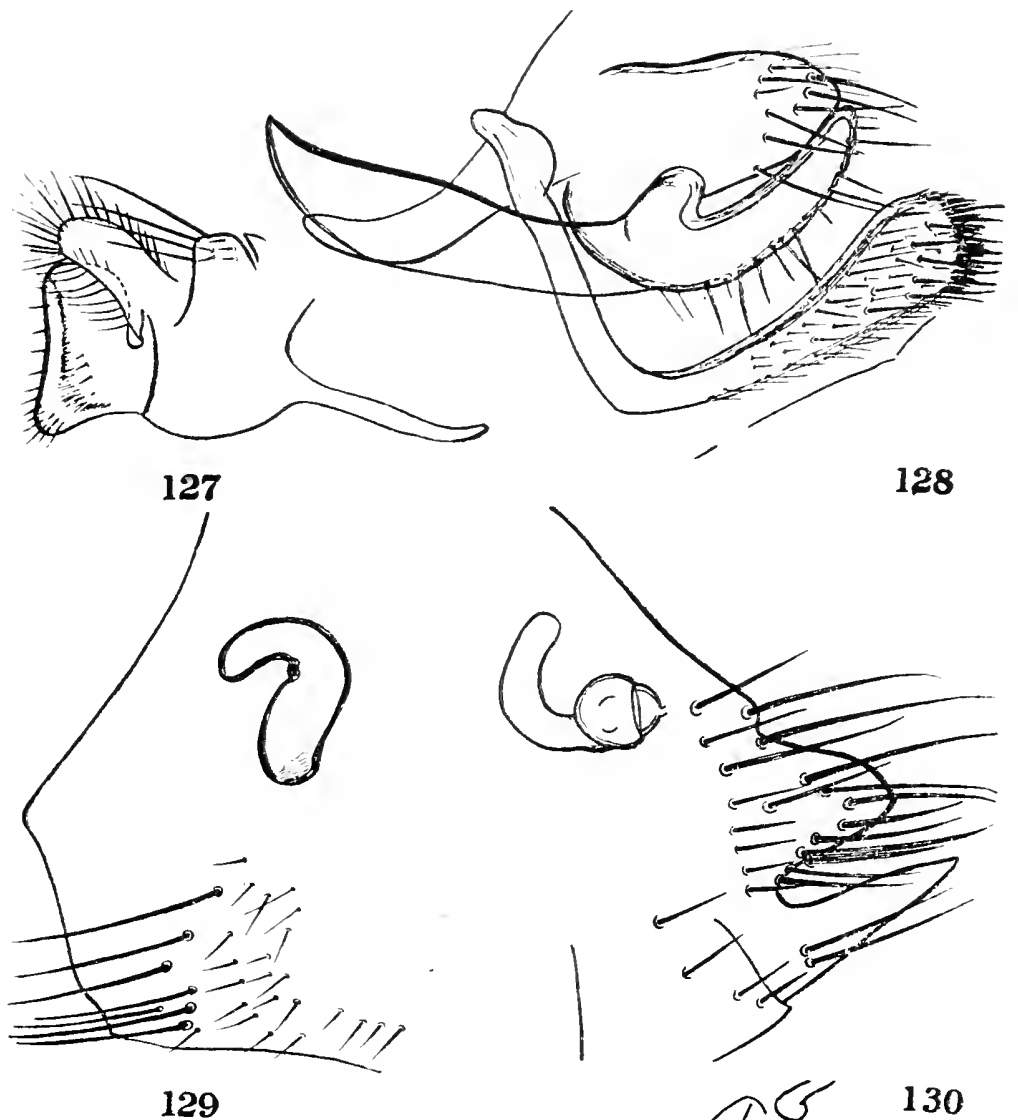

128
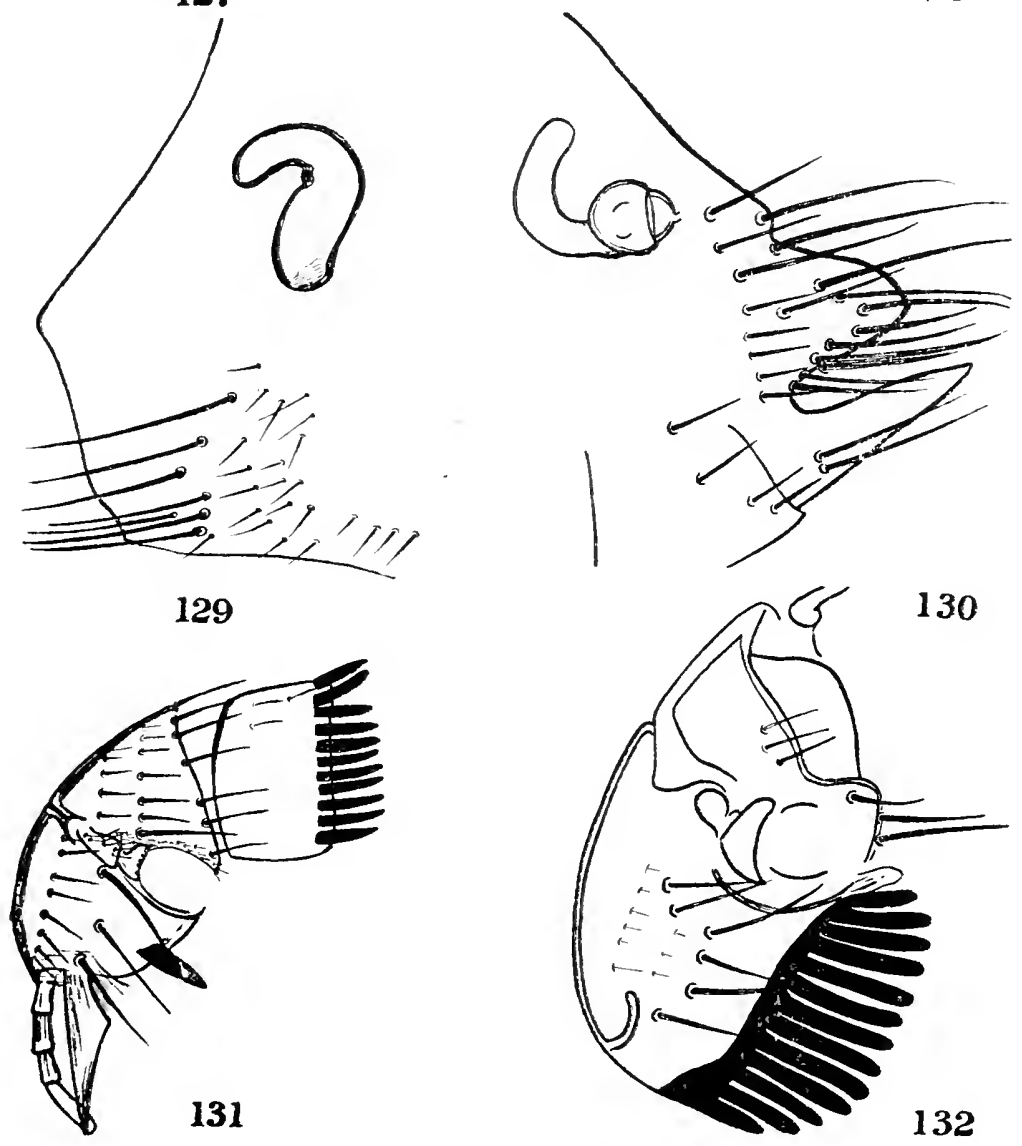


\section{PLATE XXVI}

\section{Figure}

133. Doratopsylla curvata Rothschild, head of female.

134. Doratopsylla blarinae C. Fox, head of female.

135. Idem, receptaculum seminis and sternite VII.

136. Doratopsylla curvata Rothschild, receptaculum seminis and sternite VII.

137. Doratopsylla blarinae C. Fox, movable finger and process of clasper.

138. Doratopsylla curvata Rothschild, movable finger and process of clasper. 
Plates

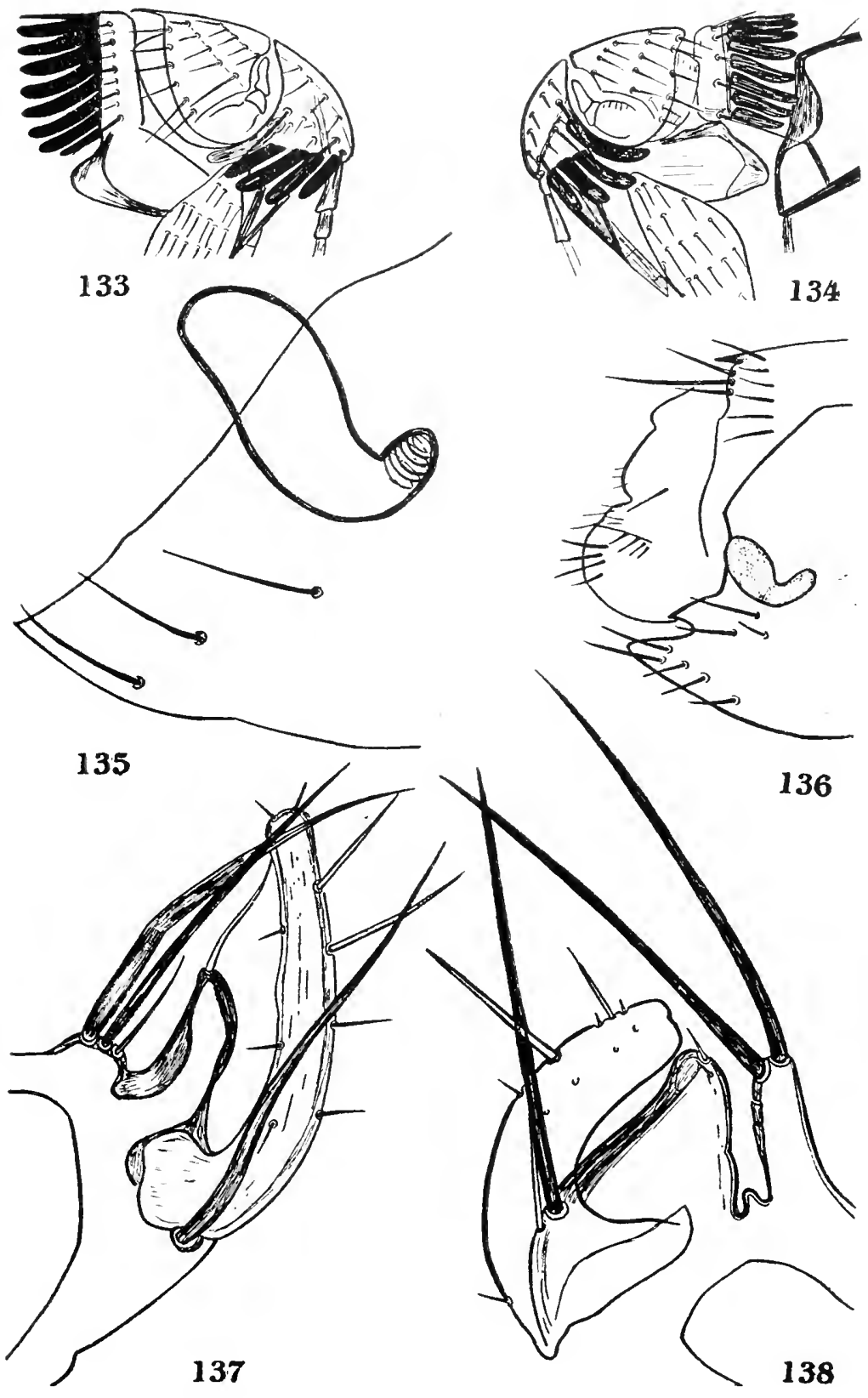




\section{PLATE XXVII}

\section{Frgure}

139. Epitedia wenmanni (Rothschild), head of female.

140. Epitedia testor (Rothschild), receptaculum seminis and sternite VII (after Rothschild).

141. Epitedia faceta (Rothschild), male genitalia (after Rothschild).

142. Epitedia wenmanni (Rothschild), receptaculum seminis and sternite VII.

143. Epitedia faceta (Rothschild), receptaculum seminis and stemite VII (after Rothschild).

144. Epitedia wenmanni (Rothschild), male genitalia. 
Plates

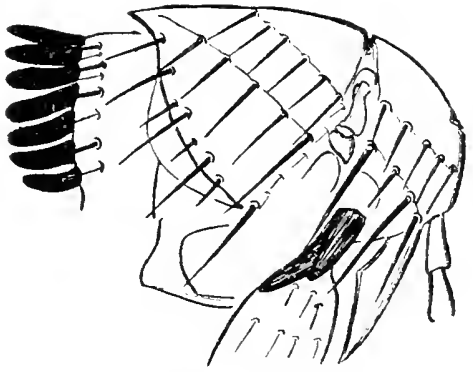

139

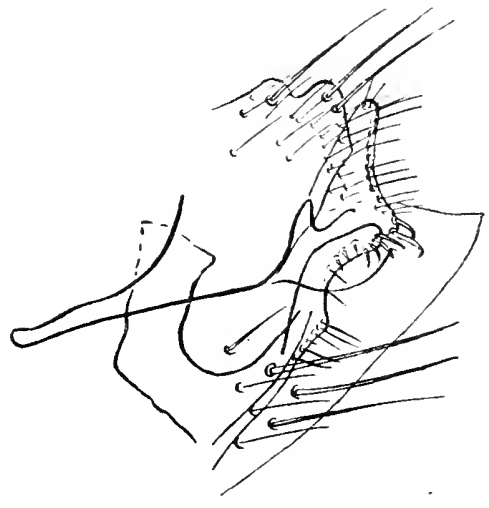

14.1
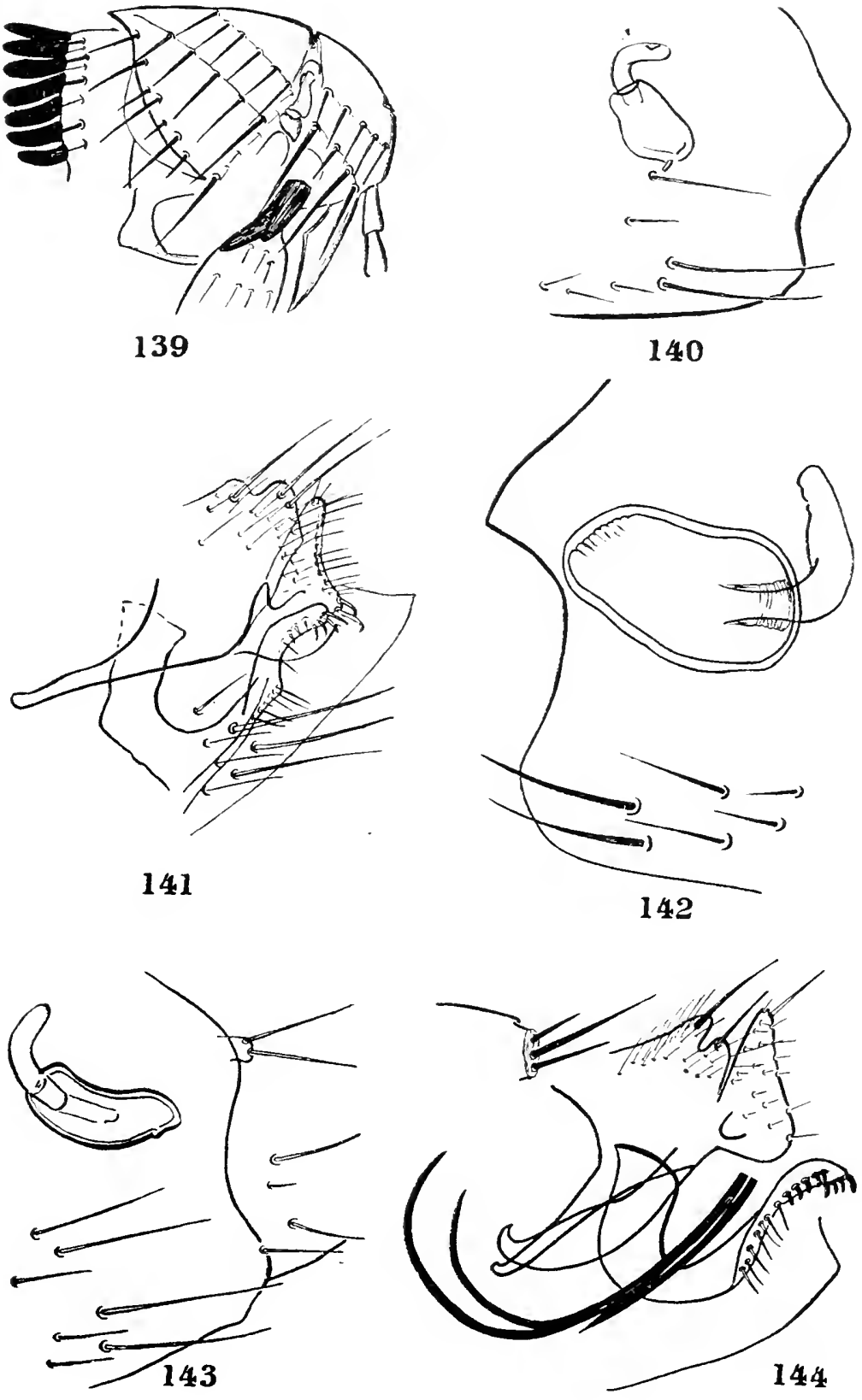


\section{PLATE XXVIII}

\section{Figure}

145. Catallagia onaga Jordan, movable finger, clasper, and manubrium.

146. Catallagia borealis Ewing, head of female.

147. Idem, sternite VII.

148. Conorhinopsylla stanfordi Stewart, head of female.

149. Idem, receptaculum seminis and sternite VII.

150. Idem, male genitalia. 

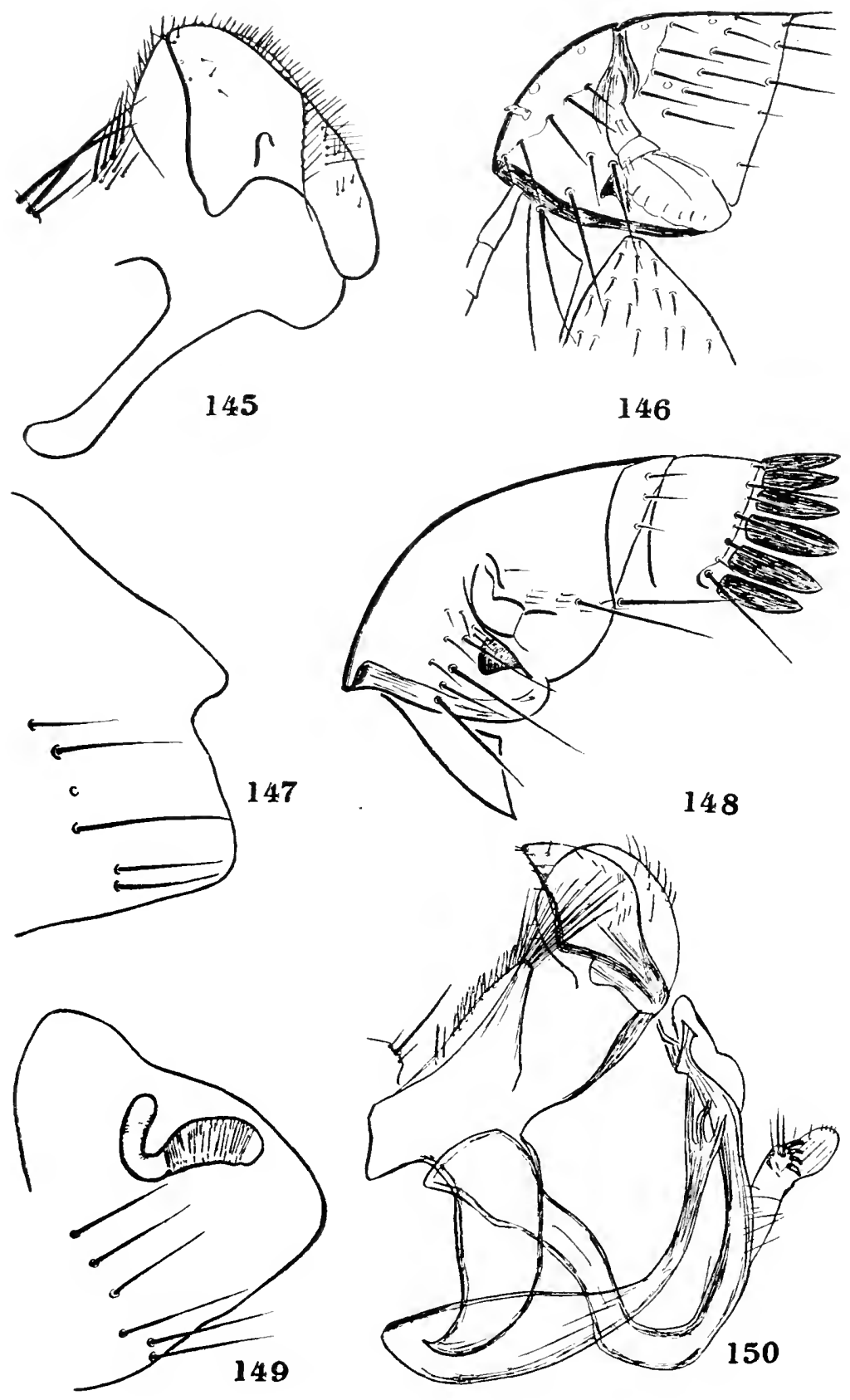


\section{PLATE XXIX \\ Myodopsylla insignis (Rothschild)}

\section{Figure}

151. Receptaculum seminis and sternite VII.

152. Head of male.

153. Penis and spring.

154. Sternite IX of male.

155. Paramere of penis, viewed from one side (only one-half of the structure showing).

156. Movable finger and clasper. 
Plates
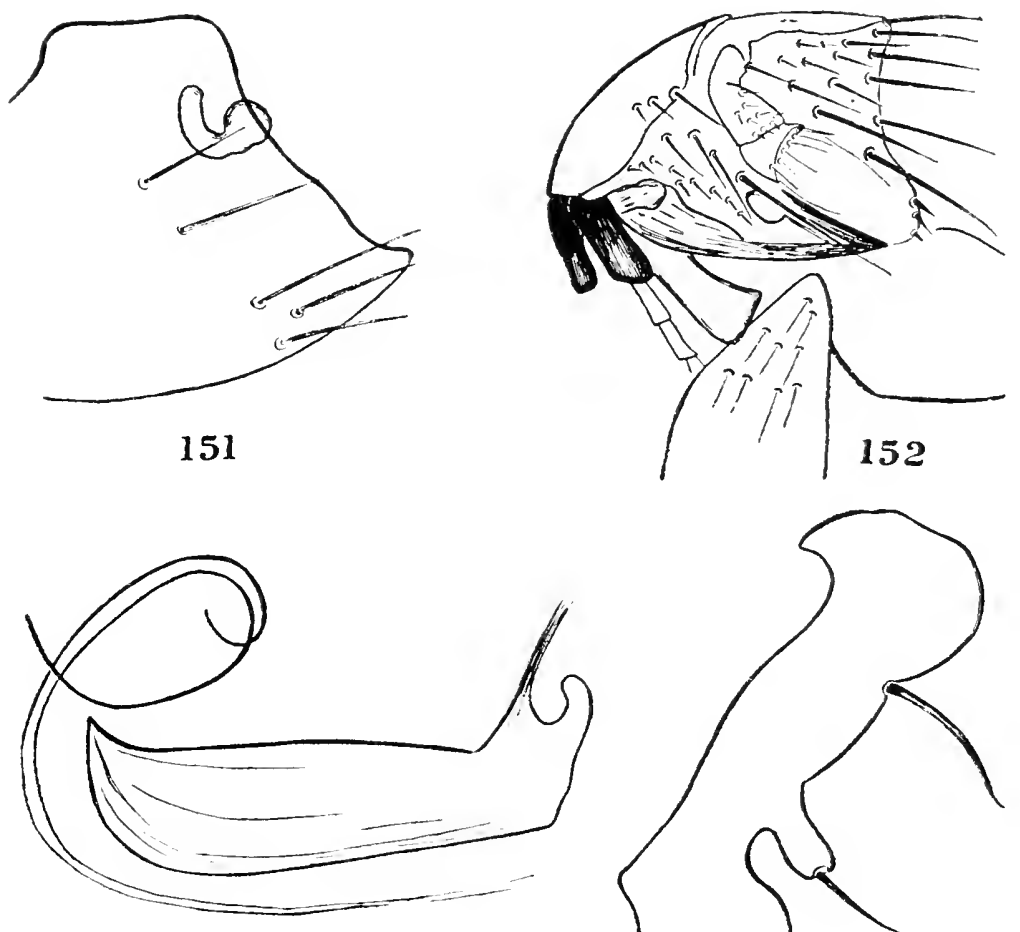

153
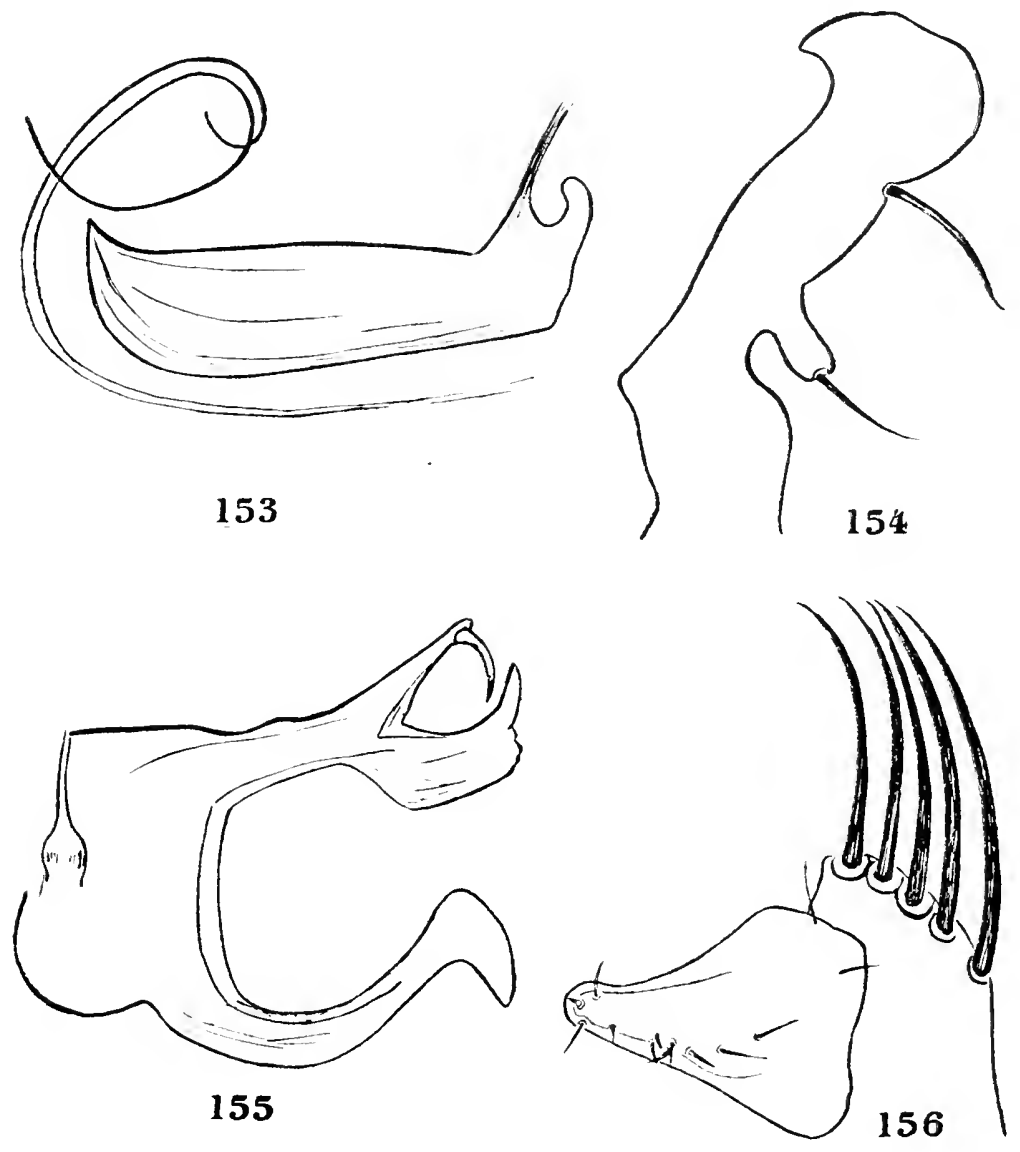


\section{PLATE XXX}

Eptescopsylla chapini (Jordan)

\section{FIguRE}

157. Male genitalia.

158. Receptaculum seminis and sternite VII.

159. Head of female.

160. Head of male.

161. Receptaculum seminis. 

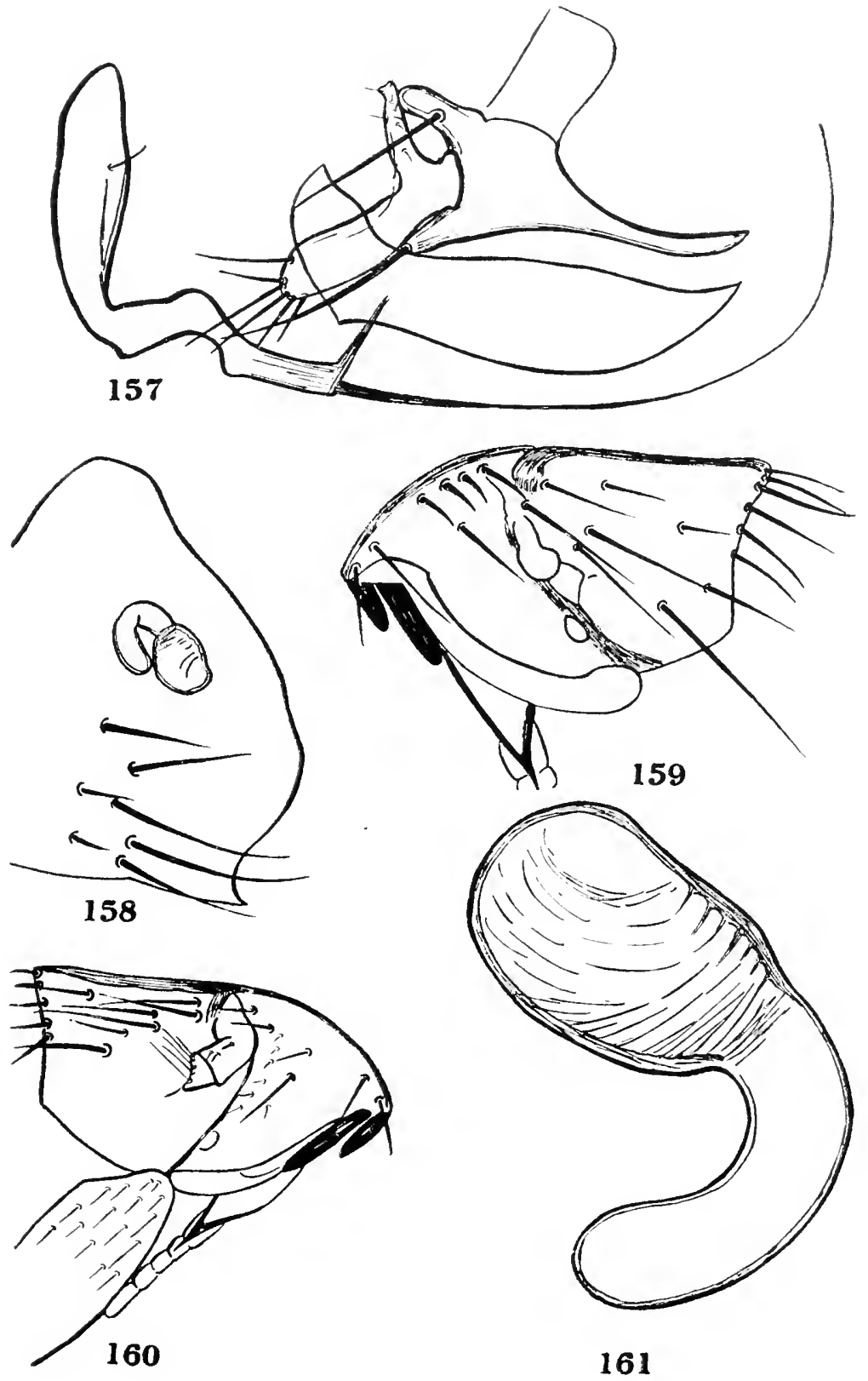
PLATE XXXI

Sternopsylla texana C. Fox

\section{Figure}

162. Receptaculum seminis and sternite VII.

163. Posterior end of male abdomen.

164. Male genitalia.

165. Head of male.

166. Receptaculum seminis. 
Plates
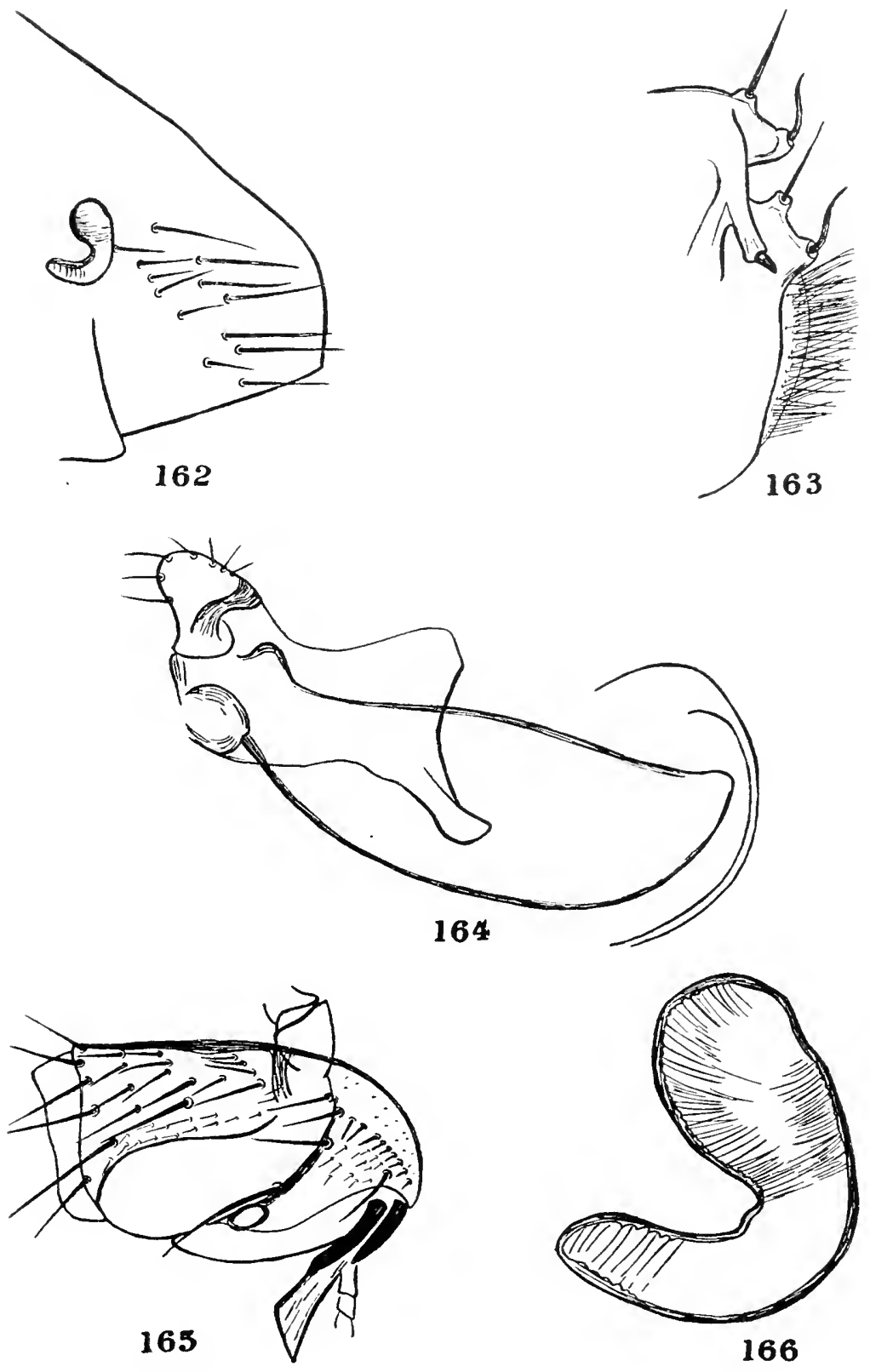


